\title{
AN ANALYSIS OF NEW BRUNSWICK'S INTERNATIONAL POLICIES AND PRACTICES
}

By

RAJEEV VENUGOPAL, B.A., M.Sc.

A dissertation submitted to the Faculty of Graduate Studies and Research in partial fulfilment of the requirements

for the degree of

\author{
Doctor of Philosophy \\ Department of Political Science
}

\author{
Carleton University \\ Ottawa, Ontario, May 2010
}

CRajeev Venugopal, 2010 


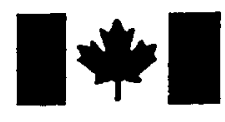

Library and Archives

Canada

Published Heritage

Branch

395 Wellington Street Ottawa ON K1A ON4

Canada
Bibliotheque et

Archives Canada

Direction du

Patrimoine de l'édition

395, rue Wellington

Ottawa ON K1A ON4

Canada

Your file Votre référence

ISBN: 978-0-494-81552-6

Our file Notre référence

ISBN: 978-0-494-81552-6

NOTICE:

The author has granted a nonexclusive license allowing Library and Archives Canada to reproduce, publish, archive, preserve, conserve, communicate to the public by telecommunication or on the Internet, loan, distribute and sell theses worldwide, for commercial or noncommercial purposes, in microform, paper, electronic and/or any other formats.

The author retains copyright ownership and moral rights in this thesis. Neither the thesis nor substantial extracts from it may be printed or otherwise reproduced without the author's permission.
AVIS:

L'auteur a accordé une licence non exclusive permettant à la Bibliothèque et Archives Canada de reproduire, publier, archiver, sauvegarder, conserver, transmettre au public par télécommunication ou par l'Internet, prêter, distribuer et vendre des thèses partout dans le monde, à des fins commerciales ou autres, sur support microforme, papier, électronique et/ou autres formats.

L'auteur conserve la propriété du droit d'auteur et des droits moraux qui protège cette thèse. $\mathrm{Ni}$ la thèse ni des extraits substantiels de celle-ci ne doivent être imprimés ou autrement reproduits sans son autorisation.
In compliance with the Canadian Privacy Act some supporting forms may have been removed from this thesis.

While these forms may be included in the document page count, their removal does not represent any loss of content from the thesis.
Conformément à la loi canadienne sur la protection de la vie privée, quelques formulaires secondaires ont été enlevés de cette thèse.

Bien que ces formulaires aient inclus dans la pagination, il n'y aura aucun contenu manquant.

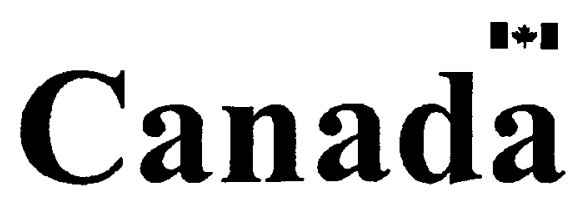




\begin{abstract}
This dissertation is the first examination of New Brunswick's international policies and practices in the context of paradiplomacy. In Canada, while scholarship in this field is not new, studies have focused nearly exclusively on the experiences of larger provinces such as Ontario, Québec, Alberta and British Columbia, and have referred to the activities of smaller provinces as spasmodic and uncoordinated. Analysis of New Brunswick's first International Strategy in 2003, however, suggests that more interesting and deeper patterns of strategic behaviour are evident.

Constitutional jurisdiction over international matters is non-definitively laid out in the Constitution Act, 1982. As such, Canada's system of federalism and federal-provincial-territorial relations has relied on intergovernmental affairs to promote collaboration and mitigate conflict in policy areas of shared interest or concurrent jurisdiction. In New Brunswick's case, it is argued that its small size is manifested in a greater willingness to proactively identify methods and modalities with which to seek partnership with the Government of Canada, specifically through DFAIT. To this end, the policy areas of trade and investment, immigration, and participation in La Francophonie are examined from a provincial, federal and shared perspective.
\end{abstract}

Deriving from this policy overview, four arguments that form the basis for this analysis of New Brunswick's international policies are explored.

First, it is argued that upon closer inspection, several aspects of New Brunswick's International Strategy are fundamentally flawed, to the extent that it does not constitute a viable strategy due to its reliance on status quo activities and lack of an implementing budget. Second, it is argued that although flawed, the International Strategy has functional value in breathing new life into the concept of "province-building," critiqued in particular by Young, Faucher and Blais. This value can be expressed as a hybridized version of the old province-building concept that equated provincial empowerment with anti-Ottawa oriented competition. Third, it is argued that while modern globalization has resulted in a powerful new role for regional governments in federations to participate on the world stage, New Brunswick benefits from a strong central government role in international relations given the strategic and programmatic benefits it derives from collaborative alliances and partnerships. Lastly, it is argued that in some respects an apparent lack of rationality in various elements of the International Strategy can be evaluated through the "Garbage Can Model" of organizational design, a concept developed as counterpoint to other theories of decision-making that hinged on the notion of the "rational actor."

The study concludes with the argument that despite various flaws to New Brunswick's first attempt at a corporate international strategic approach, there are valuable lessons that can be learned as the Province continues to pursue international interests abroad. 


\section{ACKNOWLEDGEMENTS}

This dissertation will be met with mixed feelings by my colleagues. While some anticipated it would laud New Brunswick's International Strategy, policies and practices, some of the arguments advanced will cause surprise and raised eyebrows. At times I questioned whether this dissertation should be brought to its full and unrestrained conclusions, but having done so, note that the views expressed herein are mine alone, and do not reflect the policies of the Province of New Brunswick.

In the end, that which I sought to accomplish could not co-exist with a fear of inquiry and of questioning and challenging assumptions (within conflict of interest parameters established at the outset of the study). Despite the discomfort it may bring about, I hope it provokes debate in my beloved home province of New Brunswick. Academic freedom and independence of thought and criticism must reign supreme, and career civil servants can offer tremendous insight into the workings of government when afforded the chance to reflect on their work and offer informed advice to their political masters.

My sincere thanks to Dr. Elliott Tepper for his early guidance, and my supervisor Dr. Jonathan Malloy who consented to become my supervisor and provided special assistance in dealing with administrative matters related to my extended time in the program. His patience is appreciated, as is the administrative help given by Anna Kim, the Department's Graduate Students Administrator. I am grateful to have studied under the late Dr. Jeyaratnam Wilson of the University of New Brunswick. I remember his classes and counsel, and I miss him. Thanks to Dr. David Bedford, Chair of UNB's Department of Political Science for the opportunity to lecture over these last few years, which strengthened my resolve to complete this program, and Dr. Don Desserud for his encouragement and insight into province-building at a key point in the writing of this dissertation. I also thank my parents for their persistence that I "just get it done," and our politically-charged kitchen table battles.

"At the end, you think about the beginning."

It's a line I once heard in a movie. Marriage, three children (Maddy, Kaden, Macek), three jobs totaling over twelve years of full-time employment between the Parliament of Canada and the New Brunswick Public Service, four homes in three cities between Ontario and New Brunswick, two nomination races and one run at federal office, two business start-ups and a white to blackbelt, not to mention two thesis supervisors- all of this happened in the time I have pursued my doctoral studies.

It has truly been a long, grueling journey.

Through it all, my wife (Angela Legue) pushed me to keep writing, picked up the slack I created and encouraged me to finish what I had started. Her faith in me got me through the tough times and self doubt. I thank her for putting her own dreams and aspirations on hold while I pursued several of mine, and dedicate this work to her. She's been a good friend and wonderful companion, and all the words in the world cannot express how much she means to me as we move on to the next chapter of our life together. 


\section{TABLE OF CONTENTS}

\section{CHAPTER I: INTRODUCTION 1}

\begin{tabular}{|c|c|c|}
\hline \multicolumn{3}{|l|}{ Background } \\
\hline \multicolumn{3}{|c|}{ New Brunswick's International Challenge } \\
\hline Main Arguments & & \\
\hline The Small Province Factor & & 19 \\
\hline Financial Capacity & & 25 \\
\hline Gaps in Paradiplomatic Studie & & 28 \\
\hline Why Cooperate with the Feds & & 33 \\
\hline Research and Organization & 37 & \\
\hline Sources & 37 & \\
\hline Chapters Layout & 41 & \\
\hline General Remarks & 45 & \\
\hline
\end{tabular}

CHAPTER II: THEMATIC AND CONCEPTUAL OVERVIEW

Background 49

Canadian Provinces as International Actors 50

Previous Studies of Provinces and International Activities

New Brunswick

57

The Larger Provinces

61

The Rise of Paradiplomacy

66

The Impact of Nomenclature $\quad 66$

New Pressures on Federations $\quad 70$

From State Centricity to Paradiplomacy 75

Critics and Contrarians 82

Trends in Canada's Constitutional History 85

Prologue- Early Concerns of the Founding Fathers 85

Confederation and After

90

Canada's Federal System 99

Canadian Federalism 107

Classical Federalism 107

Cooperative and Sometimes Competitive Federalism 108

Executive Federalism $\quad 111$

Double-Image Federalism 119

Province-Building and the Garbage Can Model of Organizational Design 121

Unconventional Approaches $\quad 121$

Province-Building 122

Garbage Can Model $\quad 130$ 


\section{CHAPTER III: NEW BRUNSWICK AND ITS INTERNATIONAL STRATEGY 141}

$\begin{array}{cc}\text { Brief History } & 143 \\ \text { Economy } & 145\end{array}$

Background to the International Strategy 148

New Brunswick's International Strategy 157

Intergovernmental Affairs 157

Business New Brunswick 159

Foreign Affairs and International Trade 163

Prospering in a Global Community: New Brunswick's International Strategy 168

External Strategic Interests $\quad 171$

Internal Strategic Interests $\quad 178$

International Travel Advisory 184

Budget Allocation 192

Other Aspects of Federal-Provincial Collaboration and the International Strategy 194

The New Brunswick International Day in Ottawa (NBDO) 198

International Business Symposium (IBS) 201

Assessing Implementation 203

CHAPTER IV: INTERSECTING POLICIES AND JURISDICTIONS

$\begin{array}{cc}\text { Introduction } 211 & \\ \text { Trade and Investment } & 214 \\ \text { Provincial Interests } & 214 \\ \text { Investment } & 215 \\ \text { Trade } & 224 \\ \text { Federal Interests } & 232\end{array}$

Bureaucratic Organization 237

Case Example: Canada's Mission in India 240

Policy Intersections and Collaborative Mechanisms 244

Federal/Provincial/Territorial Co-location Program 247

Atlantic Trade and Investment Partnership 251

Trade Team New Brunswick 252

CTRADE 254

Team Canada Atlantic 255

Immigration 261

Shared Training 257

Provincial Interests 264

Bureaucratic Organization 265

Facts and Figures $\quad 267$

Federal Interests 275

Policy Intersections and Collaborative Mechanisms 277

Inter-Jurisdictional Breakdown: The Modern School in India Debacle 285 
La Francophonie 288

Provincial Interests 293

Federal Interests 301

Organizational Goals 301

Policy Intersections and Collaborative Mechanisms 305

A Brief Historical Recap 305

Québec, Ottawa and the Road to the ACCT 306

International Development 315

Other Activities $\quad 318$

CHAPTER V: ANALYSIS AND CONCLUSION

322

Introduction $\quad 322$

Assessment of the International Strategy's Design, Implementation and Evaluation 323

Design and Implementation $\quad 326$

Evaluation 329

Impact Analysis $\quad 330$

Process Analysis $\quad 331$

Does Size Matter? 336

Size in the Future 338

Towards a Hybridized Model of Province-Building 340

Proposition 1- Provincial Resistance to Federal Incursions 342

A Hybridized Province-Building Model 350

Garbage Can Modeling $\quad 352$

Pluralism 353

Deviations from the ISWG to the Legislature $\quad 357$

The Value of Participation $\quad 359$

Public Choice Theory 361

The Garbage Can Model 364

Solutions Leading Problems 365

Demonstrations of Irrational Policy Articulation 368

GCM and International Stewardship- Commitments and Reported Progress

372

Rational Actor Response to Perceived Irrational Demands 375

Implications Regarding Canadian Federalism 377

Issues for Future Consideration 383

Final Remarks 385

Policy Recommendations $\quad 385$

Conclusion 388

BIBLIOGRAPHY 391 


\section{ABBREVIATIONS}

ACCT

ACOA

ATIP

BNA

BNB

BOM

BRIC

CFP

CFSI

CIC

CIDA

CONFEMEN

CONFEJES

$\mathrm{CSO}$

DFAIT

DIIR

ECO

FDI

FOLB

$\mathrm{F} / \mathrm{P} / \mathrm{T}$

GCM

GDA

IBS

IGA

ISWG

ITA

JCPC

MOU

MSI

NAFTA

NBIDO

NEG/ECP

OIF

OHR

$\mathrm{P} \& \mathrm{P}$

PNB

PNP

POGG

SME

SSEA

STC

TCA

TCS
Agency for Cultural and Technical Cooperation

Atlantic Canada Opportunities Agency

Atlantic Trade and Investment Partnership

British North America (Act)

Business New Brunswick

Board of Management Committee of Cabinet

Brazil, Russia, India, China

DFAIT Federal-Provincial Division

Canadian Foreign Service Institute

Citizenship and Immigration Canada

Canadian International Development Agency

Conference of Ministers of Education in French-Speaking Countries

Conference of Minister of Youth and Sports in French-Speaking Countries

Civil Society Organization

Department of Foreign Affairs and International Trade

Department of Intergovernmental and International Relations

Executive Council Office

Foreign Direct Investment

Francophonie and Official Languages Branch

Federal/Provincial/Territorial

Garbage Can Model

General Development Agreement

International Business Symposium

Department of Intergovernmental Affairs

International Strategy Working Group

International Travel Advisory

Judicial Committee of the Privacy Council

Memoranda of Understanding

Modern School in India

North American Free Trade Agreement

New Brunswick International Day in Ottawa

New England Governors/ Eastern Canadian Premiers

Organisation internationale de la francophonie

Office of Human Resources

Planning and Priorities Committee of Cabinet

Province of New Brunswick

Provincial Nominees Program

Peace, Order and Good Governance

Small to Medium Sized Enterprise

Secretary of State for External Affairs

Senior Trade Commissioner

Team Canada Atlantic

Trade Commissioner Service 


\section{TABLES}

1. Total Equalization Payments-2006-2007 (\$ millions)

2. Total Family Median Income

3. Total Population (millions)

4. Percentage of Provincial Revenues From Equalization and Major Transfers

5. Population Urban and Rural, By Province, 2001

6. Province-Building Key Characteristics and Associated Rebuttals

7. New Brunswick- General Information

8. Major Components of New Brunswick's International Strategy

9. Destination of New Brunswick's International Exports ( $\$ /$ thousands)

10. Destination of New Brunswick's International Exports (\$/thousands)

11. New Brunswick International Strategy Action Priorities

12. Jobs Created from Outside (non-NB) Investment

13. Global Investment to New Brunswick (2000-2007)

14. New Brunswick's Global Trading Partners 2001-2003 (\$ thousands)

15. New Brunswick's Global Trading Partners, 2005-2007 ( $\$$ thousands)

16. New Brunswick Exports by Product ( $\$$ thousands)

17. New Brunswick Exports by Product ( $\$$ thousands)

18. Population of Canada and New Brunswick

19. Compendium of New Brunswick's Activities in La Francophonie

20. Population by mother tongue, by province and territory (2006 Census) (New Brunswick, Quebec, Ontario)

21. BNB Actual Expenditures by Fiscal Year 


\section{Chapter I: Introduction}

\section{Background}

In late 2001, the Province of New Brunswick began a policy exercise to better understand and appreciate how globalization affected the province and what social and economic factors ought to be considered when formulating and implementing policies respecting its international relations. ${ }^{1}$ While it was tempting for the average public servant to view foreign policy and international relations as a policy area for the most part dominated by the federal government, Canadian provinces had been steadily ramping up their pursuit of international self interest on the international stage since the 1960 s, helped in no part by Canada's own lack Constitutional lack of definitiveness on the matter. Vengroff and Rich point out, "Canada's federal structure, the lack of clarity in its constitutional arrangements, growing globalization, and diversity contribute to the emergence of the provinces as more active initiators and players in the foreign policy arena."2

This said, despite efforts to leverage opportunities afforded by such forces, New Brunswick's historically uncoordinated and ad hoc approach to international affairs was a liability, and provincial executives set out to develop ways with which to address the situation.

1 Bernard Lord, Premier, 1999-2006. Shawn Graham, Premier, 2006-.

2 Richard Vengroff, Jason Rich, "Foreign Policy by Other Means: Paradiplomacy and the Canadian Provinces," in Patrick James, Nelson Michaud, Marc J. O'Reilly, (eds.), Handbook of Canadian Foreign Policy, Maryland, Lexington Books, 2006: 105. 
While New Brunswick had historical trade relations in the Atlantic and North-east American regions and modern day interactions with the New England region through political discussions (for example) pertaining to the Atlantica ${ }^{3}$ regional economic integration and development of Atlantic Canada inter-modal transportation infrastructure to facilitate greater efficacy in North-South trade relations through the Atlantic Gateway ${ }^{4}$ initiative, lack of a formal international policy seemed to suggest there was little by way of a centralized or corporate policy on the province's international outlook. Questions posed by the Lord administration during its first mandate (1999-2003) such as "why do we do what we do and where?" ${ }^{, 5}$ went unanswered, and the senior bureaucracy was pressured for further information on the "big picture" of New Brunswick's intergovernmental and international relations as the erstwhile new government continued on its policy-rich first term trajectory. ${ }^{6}$

3 See for example the Atlantic Institute of Market Studies (AIMS) affiliated website for the Atlantica project, URL: http://www.atlantica.org, Accessed: September 2008; Robin Neill, "Historical Atlantica: How the Impact of the Past Will Shape Our Future," AIMS, Halifax, September 2007.

$4 \quad$ See Communications New Brunswick, "Transportation Minister in India to Promote Atlantic Gateway," February 15, 2008; ACOA News Release, "Minister Mackay to Lead Canada's Atlantic Gateway Business Mission to India," Fredericton, New Brunswick February 14, 2008, "The Atlantic Gateway is an important part of the Government of Canada's strategy to improve our trade competitiveness through gateways which connect North America with the world [...]."

5 Interview, Bernard Lord, Premier of New Brunswick, 2004.

6 Thanks to John Kershaw, former Deputy Minister of New Brunswick's Department of Intergovernmental Affairs, for his insight into key decision-making processes during this formative period, and for offering perspective into the Province's decision-making calculus when positioning the Province's interests along and against those of the federal government. 
Although New Brunswick's total bureaucratic footprint was smaller ${ }^{7}$ than some federal departments and most other provincial governments in Canada, a quality believed to accord to the province a greater ability to manage policy coordination, actually determining the effectiveness of the Province's efforts in international relations was nearly impossible. Understanding what provincial officials were doing where was difficult given that there were no centralized document or record-keeping protocols outside of financial documents retained for central accounting purposes, and key performance indicators to measure operational successes and failures as they related to international activities did not exist in any systematized format. International work done by individual departments was disconnected and conducted in highly compartmentalized silos, with departments sometimes pursuing their parochial interests independent from the federal government whose own interests sometimes intersected with those of the Province.

In response to these challenges the Province set about to develop its first-ever International Strategy. ${ }^{8}$

This strategy was premised on the belief that increasing globalization required a strategic plan of action, and because New Brunswick was a small province in relation to the rest of Canada, it had to approach its international affairs in a calculated, deliberate manner with

$7 \quad$ As of December 31, 2005, Part I of the New Brunswick public service, which includes ministries most commonly referred to as the Civil Service (excluding teachers, hospital staff and other crown corporations and utilities) was comprised of 11,957 employees. Office of Human Resources, "Government of New Brunswick Workforce Profile," Province of New Brunswick, December 31, 2005.

8 Province of New Brunswick, Prospering in a Global Community: New Brunswick's International Strategy, Fredericton, 2003. 
an eye to promoting effectiveness and results-based strategic plans. ${ }^{9}$ After all, New Brunswick's small size and limited resources required an approach somewhat different than those of larger provinces such as Ontario, Québec and Alberta whose coffers appeared to New Brunswick public officials as overflowing. Leveraging federalprovincial cooperation was seen as one way to compensate for the obvious interprovincial asymmetry. Early discussions with the federal government on IGA's intentions to develop an international strategy even revealed tentative yet cautious support for the project from DFAIT and a number of other federal ministries with international interests.

Development of the International Strategy did not take place in a policy vacuum. With respect to the rich policy environment referred to earlier, Bernard Lord $^{10}$ himself was a fond adherent to the rationality of developing policy frameworks that treated the work of government as holistic and interconnected policy subsystems. In this way of thinking, governmental policy articulation should be centralized, logical and modular, and ideally, would relate to a central organizing principle. In the case of his administration, this central theme took form in a social and economic growth agenda called the "Prosperity Plan."11

9 Interview, John Kershaw, Deputy Minister, Department of Education, May 3, 2007.

10 See Jacques Poitras, The Right Fight: Bernard Lord and the Conservative Dilemma, New Brunswick, Goose Lane Editions, 2004 for insight into this aspect of Lord's personality.

11 In 2001 Lord stated, "We are competing in a global economy. When we have the right competitive environment, we win. We can't rest on our laurels. We must continue to be competitive. You cannot just expect prosperity. You have to choose it to have it and that requires key policy directions. And today's globalized economy is making those directions clear." Bernard Lord, State of the Province Address 2001, Fredericton, New Brunswick, February 28, 2001. Also see Province of New Brunswick, Greater Opportunity: New Brunswick's Prosperity Plan, 2002. 
As part of its many recommendations, the Prosperity Plan called for creation of a formal provincial international strategy that could be used to guide New Brunswick's extraterritorial policies and efforts in a coordinated, rational manner.

In an era of globalization, most of Canada's provinces are beginning to take on a more active and aggressive role in positioning themselves in the international marketplace [...] New approaches to the international arena will be pursued [including] the development of a New Brunswick international strategy. ${ }^{12}$

Barely months prior to the tabling of the Prosperity Plan in the New Brunswick Legislature, ${ }^{13}$ the Deputy Minister of Intergovernmental Affairs (IGA) was summoned by the Premier to develop an International Strategy that would:

a) Promote intra-governmental collaboration and policy integration;

b) Advance provincial interests on the international stage in specific policy domains; and

12 Province of New Brunswick, Prosperity Plan, 2002: 40.

13 Communications New Brunswick, News Release, "Government Releases New Prosperity Plan for New Brunswick," February 5, 2002. True to the claim that Lord expended particular efforts to incorporate rationality in policy construction, "This plan has been formed on four main building blocks: Investing in People, Creating a Competitive Fiscal and Business Environment, Embracing Innovation, and Building Strategic Infrastructure. Each building block has four cornerstones, or priority areas that will be undertaken in each category with specific actions, programs, and progress indicators, which will measure success. More than 60 action priorities are identified already to put this plan into action. The province will implement these actions through three implementation strategies integrated across the four building blocks. These are: Economic Diversification and Clustering, Community Economic Development and Strategic Partnerships with government, business, universities and community colleges, workers, and communities." 
c) Optimize intergovernmental relations and strategic collaboration with the Government of Canada in areas of provincial and shared policy jurisdiction.

This International Strategy ${ }^{14}$ led to IGA being re-titled as the Department of Intergovernmental and International Relations (DIIR) in the spring of 2003 to reflect its revised mandate, ${ }^{15}$ as well as realign it as the principal government agency responsible for its implementation.

[...] the Province of New Brunswick will designate the new Department of Intergovernmental and International Relations as the lead corporate agency responsible for coordinating the implementation of the international strategy. The new department will work in concert with other departments to ensure a corporate approach to the province's international activities and coordinate the approval of new international commitments and agreements. ${ }^{16}$

While the above-mentioned three goals of this International Strategy guided its development, the ultimate objectives of the strategy were to:

a) Develop and pursue policy priorities that would advance New Brunswick's needs as a small province with its own unique socio-economic circumstances;

b) Ensure that a whole-of-government, corporate approach towards pursuing the Province's international interests was engaged; and

$14 \quad$ Province of New Brunswick, International Strategy, 2003.

Re-named IGA back again in early 2006. Given the several incarnations of this department, to avoid confusion the term IGA will be utilized throughout this dissertation. 16 Province of New Brunswick: International Strategy, 2003: 25. 
c) Usher in a new era of federal-provincial collaboration in international affairs while respecting the boundaries and constraints of Canada's federal and constitutional framework

With respect to the study of New Brunswick's modern political system and the larger study of Canadian political science, it is here that scholarly literature begins to thin and reveal gaps with respect to the confluence of New Brunswick's international policies, the particular experience of smaller Canadian provinces pursuing extra-territorial interests, and the dynamics and significance of federal-provincial collaboration in Canada's larger international relations policy community.

As the International Strategy underwent a process of corporate implementation, a Progress Report was issued by IGA in January 2006 proclaiming the successful roll-out of the strategy. ${ }^{17}$ Despite the laudable goals set forth in the Prosperity Plan and International Strategy and claims of progress being made, nearly all information related to New Brunswick's international practices and the evaluation of those efforts originated from government sources. Third party verification or evaluation had simply not taken place.

On closer inspection of New Brunswick International Strategy, there arose significant challenges concerning the rationality and efficacy of the entire policy design,

17 "Since we launched our strategy in April 2003, we have made significant progress towards this goal by focusing and acting on clear priorities in strategic sectors." Province of New Brunswick, Progress Report on Prospering in a Global Community: New Brunswick's International Strategy, Fredericton, New Brunswick, January 2006: 1. 
implementation and evaluation life-cycle of the International Strategy, as well as questions as to how New Brunswick's International Strategy related to the concept of "province-building" a concept developed during the 1960s at which time interjurisdictional tensions between the federal and provincial government over spending prerogative were at an all-time high.

\section{New Brunswick's International Challenge}

Intergovernmental relations and international affairs are emerging areas of curiosity and concern for academics and public administrators. In this era of globalization, the relationship between central and regional orders of government involved in the conduct of international relations merits greater attention than is currently the case. Given that both orders of government possess their own international interests, and that Canada's system of federalism is highly decentralized ${ }^{18}$ with provinces enjoying widely-ascribed and Constitutionally-enshrined rights, there is a justifiable need to study varying models of federal-provincial cooperation and intra-provincial policy articulation. The stakes associated with this exploration are considerable, and relate to the challenge of achieving domestic prosperity in an age of globalization and change.

From an academic perspective, there are also grounds on which to conduct this study, in that not a lot of critical analyses have been undertaken on what Canadian provinces have

18 See for example Douglas M. Brown, Earl H. Fry, James Groen, "States and Provinces in the International Economy Project," in Douglas M. Brown, Early H. Fry, (eds.), States and Provinces in the International Economy, California, Institute of Governmental Studies, 1993: 12-14. 
done (or not done) internationally. ${ }^{19}$ This is not for lack of activity; Nossal observes that provincial governments "[...] have demonstrated their willingness to project themselves, and their interests, beyond their borders, reaching out into the global system [...]"20

In thinking about this project, one inescapable truth remains- New Brunswick is poor, and its inability to self-finance its own international activities influences how it pursues its interests. By its own admission, New Brunswick continues to be one of Canada's most cash-strapped jurisdictions despite its best efforts to grow the economy. For example, in the first major government-commissioned report of the Graham administration in early $2007,{ }^{21}$ a grim view of New Brunswick is presented:

To the rest of the country New Brunswick is a have-not province. It is a phrase loaded with assumptions and stereotypes about the government and people of New Brunswick. Provinces branded with this label are thought to be the little siblings in the Canadian federation, unable to provide for themselves and dependent on the federal government (and through it, wealthier provinces) for support. Like all stereotypes, it carries an uncomfortable pebble of truth. ${ }^{22}$

19 Thomas Dye famously wrote that public policy is what governments choose to "do or not do." Understanding Public Policy, Michigan: Prentice-Hall, 1987.

20 Kim Richard Nossal, "The Impact of Provincial Governments on Canadian Foreign Policy," in Douglas Brown, Earl Fry, (eds.), States and Provinces, 1993: 233.

21 For example, in January 2007 Premier Graham commissioned the Self-Sufficiency Task Force whose mandate was to develop a provincial development plan guiding the province to social and economic self sufficiency. Province of New Brunswick, Self Sufficiency Task Force, The New Brunswick Reality Report, Part I: At The Crossroads, Fredericton, January 2007.

22 Province of New Brunswick, The New Brunswick Reality Report, (italics added), 2007: 5 . 
Asides from notable periods when provincial government efforts to ramp up economic prospects were prevalent ${ }^{23}$ New Brunswick has been traditionally seen as a "have not" province, a long-standing and dubious distinction. ${ }^{24}$ To improve its lot, however, New Brunswick (and all Canadian provinces) pursues opportunities within Canada and around the world. Pursuing these opportunities, however, presents interesting resource allocation, jurisdictional and political challenges. How should New Brunswick design international policies for whose correct implementation it lacks sufficient human and financial resources? How should the Province collaborate with a federal government that, while well-resourced, has objectives sometimes at loggerheads with the province? In a highly rural, politically-attuned and conservatively-minded province like New Brunswick, to what extent should politicians allow the provincial government to be seen scouring the world for opportunities while racking up large travel bills in foreign markets? What political sensitivities come into play? Furthermore, should New Brunswick seek concessions from the federal government when other larger provinces (such as Québec) are in conflict with Ottawa over foreign policy issues?

23 See Donald Savoie, Pulling Against Gravity: Economic Development in New Brunswick During the McKenna Years, Institute for Research on Public Policy, Winter 2001.

24 "Have-not" status is not generally applied as a pejorative term despite the stigma attached to provinces that are regular recipients. Rather, it is used to identify Canadian provinces that receive equalization payments from the federal government in order to account for revenue generation shortfalls that may preclude extension of equitable and comparative-quality services in areas of provincial jurisdiction. For a succinct breakdown on the Canadian equalization calculation formula, see Richard M. Bird, François Vaillancourt, "Changing with the Times: Success, Failure and Inertia in Canadian Federal Arrangements, 1945-2002," in T.N. Srinivasan, Jessica Seddon Wallack, (eds.), Federalism and Economic Reform, USA: Cambridge University Press, 2006: 207. 
With respect to this last point, New Brunswick's small size plays a major influence in its international modus operandi, and operational spending decisions routinely made by larger provinces such as opening foreign offices, deploying Premier or Minister lead missions and working in foreign markets without federal assistance are not therefore easily made in New Brunswick. Nearly all studies on Canada's provinces in international affairs, however, focus on larger provinces such as Québec, Ontario, Alberta and British Columbia, all of which depend to a lesser degree on support from the Government of Canada. Civil servants and political executives understand firsthand this asymmetry, which is reflected in integrative policy coordination efforts and cooperative federalprovincial relations. Unfortunately, there is scant academic material and research documenting how small versus large provincial governments relate to federal ministries dealing with issues such as foreign policy, education, citizenship and immigration, cultural relations and industry and regional economic development, essentially, where policy overlaps are bound to happen given constitutionally-established intergovernmental concurrency.

If it can be said that New Brunswick's international policies are pursued with the intention of aligning them with the federal government's pursuit of its own objectives, it is tempting to assume that there is an inherent flexibility associated with the Province's identification of its own goals and objectives, or less charitably, that they are contextual and not firm or fixed. After all, if the main focus of the Province is to align its international policies with those of the federal government, it follows that there is a degree of "play" and uncertainty to its own international priorities and a degree of 
dependency on the federal government's direction by default. Feldman and Feldman allude to this tendency of smaller provinces' international policies as being "spasmodic and uncoordinated. ${ }^{.25}$ In theory, the International Strategy was to provide a structured, formal direction to the province's international efforts in a cohesive, collaborationreinforcing manner. ${ }^{26}$ In reality, however, whether those objectives were realized is up for debate.

\section{Main Arguments}

New Brunswick's development and implementation of an international strategy was generally viewed in a positive light by the federal government, as well as by a number of other provinces who sought to emulate aspects of the project. ${ }^{27}$ Even at the political level, the tabling of the International Strategy in the Legislative Assembly did not elicit raucous debate or discussion in Chamber or in Committee. Rather, it passed through with unanimous consent with nary a whisper of dissent, or apparent concern, from members of either the Government or Opposition sides of the House. Not one question appears in the Legislative Hansard. Despite the seemingly effortless passage of New Brunswick's International Strategy through the New Brunswick Legislature and return to the

25 See Elliot J. Feldman and Lily Gardner Feldman's chapter simply titled "Canada," in Hans J. Michelmann and Panayotis Soldatos' edited volume, Federalism and International Relations: The Role of Sub-national Units, Oxford: Clarendon Press, 1990. This point is discussed in greater detail later in this Chapter.

26 Collaborative federalism is defined as a form of federal-provincial intergovernmental relations emphasizing cooperation and adoption of mutually-agreeable objectives and modus operandi over competitiveness and adoption of policies which encourage, rather than discourage, inter-jurisdictional friction and tensions.

27 For example, IGA had several discussions with officials from Nova Scotia and Manitoba on processes used to engage external stakeholders, as well as promotional efforts such as the hosting of a New Brunswick International Day in Ottawa. 
bureaucracy for implementation, I argue that it is a flawed strategy from a conceptual, operational and results-based perspective, bordering on pyrrhic given the significant process-oriented problems that arose in its intra-governmental design and implementation.

But the difficulties do not stop there. In January 2006 the Province released a Progress Report $^{28}$ on the implementation of the International Strategy. While this Progress Report indicated that many of the 58 action priorities had been accomplished or were in the process of being accomplished, there are few hard indicators or quantifiable performance metrics against which the effectiveness of those measures can be gauged. For example, in the area of trade and export promotion, a sector in which numerical indicators are readilyaccessible, it is becomes apparent that the International Strategy did not bring about any worthwhile deviation from the status quo. Simply stating that a strategy has been implemented does not make it so.

From an impact and process analysis perspective, ${ }^{29} \mathrm{I}$ believe that the International Strategy was flawed, and that the bureaucratic apparatus responsible for preparing the Progress Report was so keen on demonstrating the efficacy of their first-ever International Strategy, it was unable to look objectively at its own efforts. Had officials been able to prepare their report objectively and unencumbered from political pressure to demonstrate how efficacious the strategy was to internal and federal partners, they may

28 Province of New Brunswick, Progress Report on Prospering in a Global Community, January 2006.

29 See Leslie A. Pal, Beyond Policy Analysis: Public Issue Management in Turbulent Times, $2^{\text {nd }}$ Edition, Canada, Nelson Thomson Learning, 2001: 280-290. 
have come to the conclusion that the International Strategy was largely inconsequential. Instead, the ball was dropped.

In essence the four main arguments advanced in this dissertation are as follows: a) New Brunswick's International Strategy lacked the elements of being a new strategy, and was instead, a reaffirmation of status quo activities; b) New Brunswick's effort to develop an International Strategy (despite its weaknesses) reflects a modern effort at "provincebuilding;" c) despite the Province's efforts to carve out for itself a New Brunswick centric International Strategy, it is still served by a strong federal government presence in international relations; and d) the concept of the Garbage Can Model offers insight into the sometimes irrational and disjointed manner in which New Brunswick's International Strategy was developed and implemented.

The first argument advanced in this dissertation is straightforward- Despite the intensification of globalization and New Brunswick's goal of adopting a coherent International Strategy, and that Canada's large and small provinces generally pursue intergovernmental collaboration in international affairs, ${ }^{30}$ it is argued that in reality New Brunswick has no meaningful International Strategy. Plainly stated, it is argued that the "strategy" is not really a strategy at all. Instead, the Province has chosen to describe a series of policy documents and initiatives that despite being strategic in nature, lack the essential characteristics of an implementable policy and failed to deliver that which it called for. 
It is argued that despite New Brunswick's pragmatic approach to engendering cooperative federalism in its international relations, institutional pathologies associated with its small size force it to adopt ad hoc (versus long term and sustainable) mechanisms and modalities given inconsistent levels of support from the federal government in policy areas of mutual concern. Upon examination, New Brunswick's "new" and "first ever" International Strategy did not reflect a significant departure from the status quo, neither in practice nor in policy orientation. Rather, it was comprised of assignment of priorities to departments for corporate implementation- many of which were re-expressions of departmental priorities.

The second hypothesis is that this (albeit-flawed) International Strategy should not be entirely jettisoned, since it still has functional and symbolic value. It is argued that from the perspective of "province-building," a concept developed in the 1960s, the provinces engaged in policies designed to increase their policy capacity with respect to the constitutional and political balance of power in Canada. Though generally-accepted by the academic community as an apt description of the competitive relationship between of government, Young, Faucher and Blais critique it in 1984, and argue that provincebuilding was an outdated concept. Since then, however, provinces' efforts to increase their policy capacity have been influenced by both intensified globalization and the internationalization of areas within their constitutionally-established areas of jurisdiction. Both forces have encouraged provinces to engage in a modern form of "provincebuilding," in relation to the federal government, outside the confines of the nation-state. Through a reinvigoration of the debate over "province-building" and the meaningful 
power interplay, it is argued that New Brunswick's International Strategy allows us to revisit this critiqued concept and contest the Young, Faucher and Blais ${ }^{31}$ hypothesis based on commitments to simultaneously:

a) Safeguard areas of provincial jurisdiction from federal encroachment ${ }^{32}$ in light of their recent internationalization;

b) Compensate for New Brunswick's comparative (size related) asymmetry and resulting diminished capacity to keep pace with the international activities of other provinces; and

c) Derive support from the federal government in key areas of international interest involving the need for inter-jurisdictional collaboration and mutual support. ${ }^{33}$

Whereas examination of New Brunswick's International Strategy leads this dissertation towards the conclusion that it is not an actual strategy per se (in terms of the unity between its design, implementation and evaluation), there is a bright spot in that its development and articulation of extra-territorial objectives can be viewed as a contemporary, reinvigorated and hybridized version of "province-building."

$31 \quad$ R.A. Young, Philippe Faucher, André Blais, "The Concept of Province-Building: A Critique," Canadian Journal of Political Science, Vol. 17, No. 4, December 1984.

32 See Peter Russell, "The Supreme Court and Federal Provincial Relations: The Political Use of Legal Resources, Canadian Public Policy, 11, 2, 1985 for a discussion on how governments employ intergovernmental relations as a way to protect their jurisdictional turf.

33 Interview, John Kershaw, Deputy Minister, New Brunswick Department of Education, May 3, 2007. 
In this regard, Douglas Brown's study of global and regional integration and Canadian federalism helps contextualize how notions of "co-ordinate" government (separate but equal orders of government) and "concurrent" government (overlapping roles and responsibilities) can jointly influence foreign policy making in federal states. This supports my argument in this dissertation for an updated version of the province-building model given the emerging role Canadian provinces are playing on the world stage, especially in cases such as New Brunswick where cooperation as well as protection of turf are key policy and behavioural drivers. Brown notes,

There remains considerable room for both competitive and cooperative intergovernmental relations. The traditional view of foreign policy-making in federal states is that it is the exclusive domain of the federal (central) government. But foreign policy, broadly defined, has become blurred with domestic policy in recent decades, and is increasingly a concurrent responsibility. ${ }^{34}$

The third hypothesis considered relates to point $\mathrm{c}$ ) above, namely that despite numerous calls for a polycentric, decentralized and multi-centric approach to international relations within federal states ${ }^{35}$ (as explained below), New Brunswick is well-served by a strong federal role in international relations as a result of the pathological ${ }^{36}$ effect of its small

$34 \quad$ Brown, 1999: i.

35 See for example Gilles Paquet, "The Many Are Smarter Than the Few," Optimum, The Journal of Public Service Management, Vol. 36, Issue 4, December 2006; and Hamish Telford, "Expanding the Partnership: The Proposed Council of the Federation and the Challenge of Glocalization," Constructive and Cooperative Federalism? A Series of Commentaries on the Council of the Federation, IRPP, Montreal, 2003.

36 The term pathology as employed refers to New Brunswick's heavy reliance on collaboration with the federal government as a dysfunctionality endemic to its asymmetry to the federal government and reduced capacity for autonomous or unilateral action. The Merriam Webster's Collegiate Dictionary $\left(10^{\text {th }}\right.$ edition), Massachusetts: MerriamWebster, Incorporated, 1995 defines pathology as "the study of the essential nature of 
size. To some extent, it is argued, confusion in Canadian federalism on what role the provinces should play in international relations serves New Brunswick's interests, in that lack of systematic and established processes for federal-provincial engagement allows for the asymmetric consideration and addressing of specificities endemic to each provincial order of government. Asymmetric federalism in this scenario, it is argued, benefits the small and weak, and allows Ottawa to leverage New Brunswick in ways that reinforces the strong central role it envisages for itself on the international political stage. This hypothesis is particularly relevant to New Brunswick's participation in La Francophonie.

The fourth hypothesis advanced originated from a dilemma.

In the process of evaluating New Brunswick's International Strategy implementation, the prevalence of issues that defied logical or rational explanation gave rise to questions on how they should be assessed. It did not appear entirely appropriate to use rational actor modeling to evaluate seemingly irrational policies.

In this light, the fourth hypothesis advanced establishes that given an apparent lack of clarity with respect to the rationality and well-thought nature of the mechanisms and modalities of New Brunswick's International Strategy, combined with factors associated with the proliferation of executive federalism and elite/central agency domination in the

diseases and esp. of the structural and functional changes produced by them." (852) In this case, New Brunswick's collaborative relations with the federal government are viewed as intrinsically related to its incapacity to engage in self-help mechanisms in international relations. 
policy process, the Garbage Can Model of organizational design ${ }^{37}$ offers a useful lens through which analysis and comprehension of this policy is obtained It is later noted that this conceptual lens is partıcularly well-adapted for use in understanding policies, decisıon-makıng and organizational design that involves apparent inationahty, randomization of initiatıve design and ad hocery

The remainder of this chapter discusses broad environmental factors that influenced this choice of research topic

\section{The Small Province Factor}

For all the talk of New Brunswick as a "small province," what does this entarl? What constitutes "smallness?" What are the fundamental characterıstics of a "small" province, other than simply noting that that which is "small" is the relative size of one object of analysis in relation to another? These questions help establish the particular circumstances which make New Brunswick's experience unıque compared to studies on larger Canadian provinces

Small size, it is argued herem, flows from comparatıve analysis, and is related more to economic and human capacity rather than physical size This is to say, jurisdictions such as Singapore would be difficult to categoi1ze as "small" or "large" unless considered in the context of its capacity to act on or influence the international community While

$37 \quad$ See Michael D Cohen, James G March, Johan P Olsen, "A Garbage Can Model of Organizational Choice," Administratıve Science Quarterly, Vol 17, No 1, 1972 
Singapore's physical size is small, it wields considerable economic and industrial influence. In this way, New Brunswick is being described as "small" in an economic and social capacity, and in relation to other "larger" capacity Canadian provinces. The following five tables provide some quantification of the "small" descriptor.

Table 1 shows New Brunswick receives more money per capita from equalization payments from the federal government than all other provinces in Canada except for Prince Edward Island. From an economic dependency perspective, this demonstrates that New Brunswick relies on federal assistance to a greater extent than nearly all other provinces. Based on anecdotal conversation with officials from the Department of Finance, on a year-by-year basis equalization payments from the federal government account for approximately one-quarter of the total annual revenues of the provincial government.

\begin{tabular}{|c|c|c|c|c|c|c|c|c|c|}
\hline & NL & PEI & NS & NB & QC & $\mathrm{MB}$ & SK & $\mathrm{BC}$ & Total \\
\hline Regular & 632 & 291 & 1,386 & 1,451 & 5,539 & 1,709 & 13 & 260 & 11,282 \\
\hline Adjustment & 54 & & & & & & & 199 & 254 \\
\hline Total & 687 & 291 & 1,386 & 1,451 & 5,539 & 1,709 & 13 & 459 & 11,535 \\
\hline $\begin{array}{l}\text { Per Capita } \\
(\$)\end{array}$ & 1,334 & 2,102 & 1,475 & 1,927 & 725 & 1,445 & 13 & 107 & \\
\hline
\end{tabular}

38 Source: Department of Finance, Canada, URL: http://www.fin.gc.ca/fedprov/eqpe.html, Accessed: February 13, 2007. 
Table 2 provides information on personal, non-governmental prosperity via total household income from 2000 to 2004, and from 2004 to 2006. During this time period the following table shows that in terms of absolute levels of total wealth, New Brunswick families' income is either second or third lowest of all provinces and territories, an indicator of the populace's well-being.

\begin{tabular}{|l|l|l|l|l|l|}
\hline \multicolumn{7}{|c|}{$\begin{array}{l}\text { Total Family } \\
\text { Median Income }\end{array}$} \\
\hline & $\mathbf{2 0 0 0}$ & Change & $\mathbf{2 0 0 4}$ & Change & $\mathbf{2 0 0 6}$ \\
\hline & & & & & \\
\hline Canada & 50,800 & $14.4 \%$ & 58,100 & $9.5 \%$ & 63,600 \\
\hline NL & 38,800 & $18.8 \%$ & 46,100 & $9.5 \%$ & 50,500 \\
\hline PEI & 44,200 & $16.1 \%$ & 51,300 & $9.4 \%$ & 56,100 \\
\hline NS & 44,500 & $13.1 \%$ & 51,500 & $9.51 \%$ & 56,400 \\
\hline NB & 43,200 & $15 \%$ & 49,700 & $8.7 \%$ & 54,000 \\
\hline QC & 47,700 & $14 \%$ & 54,400 & $8.5 \%$ & 59,000 \\
\hline ON & 55,700 & $12.2 \%$ & 62,500 & $6.6 \%$ & 66,600 \\
\hline MB & 47,300 & $14.4 \%$ & 54,100 & $8.5 \%$ & 58,700 \\
\hline SK & 45,800 & $16.8 \%$ & 53,500 & $13.1 \%$ & 60,500 \\
\hline AB & 55,200 & $20.3 \%$ & 66,400 & $18.1 \%$ & 78,400 \\
\hline BC & 49,100 & $13.8 \%$ & 55,900 & $12 \%$ & 62,600 \\
\hline YK & 56,000 & $21.1 \%$ & 67,800 & $12.1 \%$ & 76,000 \\
\hline NWT & 61,000 & $30.8 \%$ & 79,800 & $11.3 \%$ & 88,800 \\
\hline NV & 37,600 & $32.7 \%$ & 49,900 & $8.8 \%$ & 54,300 \\
\hline
\end{tabular}

39 Census families include couple families, with or without children, and lone-parent families. Source: Statistics Canada. URL: http://www40.statcan.ca/101/cst01/famil108a.htm. Accessed: September 23, 2009. 
Table 3 shows New Brunswick's population from 2002 to 2006. In relation to the rest of Canada, New Brunswick's population growth is static to negative. The stgnificance of flat population growth is cross-cutting, and has implications on the size of the contributory tax base, ethno-cultural diversity and attractiveness to potential inbound FDI requiring labour force accessibility.

\begin{tabular}{|c|c|c|c|c|c|}
\hline & 2002 & 2003 & 2004 & 2005 & 2006 \\
\hline Canada & $31,372.6$ & $31,676.1$ & $31,989.5$ & $32,299.5$ & $32,623.5$ \\
\hline $\mathrm{ON}$ & $12,102.0$ & $12,262.6$ & $12,416.7$ & $12,558.7$ & $12,687.0$ \\
\hline $\mathbf{Q C}$ & $7,445.7$ & $7,494.7$ & $7,548.6$ & $7,597.8$ & $7,651.5$ \\
\hline BC & $4,115.4$ & $4,155.4$ & $4,203.3$ & $4,257.8$ & $4,310.5$ \\
\hline $\mathbf{A B}$ & $3,116.3$ & $3,161.4$ & $3,207.0$ & $3,277.6$ & $3,375.8$ \\
\hline MB & $1,155.6$ & $1,161.9$ & $1,170.5$ & $1,174.1$ & $1,177.8$ \\
\hline SK & 995.9 & 994.7 & 994.9 & 990.0 & 985.4 \\
\hline NS & 934.5 & 936.5 & 938.0 & 936.1 & 934.4 \\
\hline NB & 750.3 & 751.2 & 752.1 & 751.5 & 749.2 \\
\hline NL & 519.4 & 518.4 & 517.2 & 514.0 & 509.7 \\
\hline PEI & 136.9 & 137.3 & 137.9 & 138.2 & 138.5 \\
\hline
\end{tabular}

Table 4 shows the percentage of provincial revenues ${ }^{41}$ derived from equalization and major transfers, and demonstrates that New Brunswick, like all of the Atlantic provinces

40 Source: Statistics Canada, http://www40.statcan.ca/101/cst01/demo02a.htm. Accessed: February 13, 2007. 
are economically dependent on the federal government. These figures highlight the elevated rate of dependence that New Brunswick has on the federal government, as opposed to larger provinces. Gauging provincial reliance on federal equalization, as expressed as percentage of revenue from equalization, however, can be misleading in the context of political decisions regarding corporate and personal taxation policy.

Tax cuts implemented during the Lord administration (1999-2006) reduced provincial revenues as a percentage of total revenues (which include federal sources). While the intended goal of increased long-term economic prosperity resulting from these tax cuts (expressed through enhanced investment, job creation and consumerism) is not reflected by this higher percentage of dependency on federal equalization and major transfers, there is no guarantee that government is successful in translating lower taxation into increased economic activity.

\begin{tabular}{|c|c|c|c|c|c|}
\hline \multicolumn{6}{|c|}{ 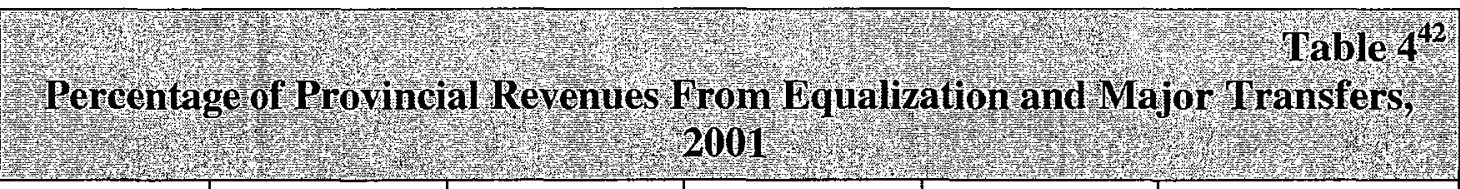 } \\
\hline & $\begin{array}{l}\text { Contribution } \\
\text { to Federal } \\
\text { Revenues ( } \$ \\
\text { Million) }\end{array}$ & $\begin{array}{l}\text { Equalization } \\
\text { (\$ Million) }\end{array}$ & $\begin{array}{l}\text { Per-Capita } \\
\text { Equalization }\end{array}$ & $\begin{array}{l}\text { Equalization } \\
\text { as \% of } \\
\text { Provincial } \\
\text { Revenues }\end{array}$ & $\begin{array}{l}\text { Transfers as \% } \\
\text { of Provincial } \\
\text { Revenues }\end{array}$ \\
\hline $\mathbf{N F}$ & $\$ 2,256$ & 1163 & 2159 & 32.6 & 44.1 \\
\hline PEI & 557 & 262 & 1886 & 27.5 & 40.5 \\
\hline NS & 4,011 & 1315 & 1397 & 24.5 & 37.0 \\
\hline
\end{tabular}

41 Explanation provided by George Richardson, Director, Economic and Fiscal Policy, Department of Finance, Province of New Brunswick, June 2007.

42 Source: Atlantic Institute for Market Studies, Brian Lee Crowley, "Equalization's Good Intentions are Not Enough," Citing Public Accounts 2001, Volume 1, Table 3.8, URL: http://www.aims.ca/equalization, Accessed: February 13, 2007. 


\begin{tabular}{|l|l|l|l|l|l|}
\hline NB & 3271 & 1152 & 1523 & 239 & 369 \\
\hline QC & 37,794 & 3,834 & 520 & $75 \%$ & $161 \%$ \\
\hline ON & 5,774 & - & - & 0 & $97 \%$ \\
\hline MB & 75,003 & 1,265 & 1,102 & $187 \%$ & $313 \%$ \\
\hline SK & 5,527 & 178 & 174 & $26 \%$ & $129 \%$ \\
\hline AB & 21,179 & - & - & 0 & 71 \\
\hline BC & 21,881 & - & - & 0 & $116 \%$ \\
\hline
\end{tabular}

Finally, Table 5 shows the percentage of total population that lives in rural versus urban areas, by province This table shows that New Brunswick has the second highest rate of rural population of any province in Canada ${ }^{43}$

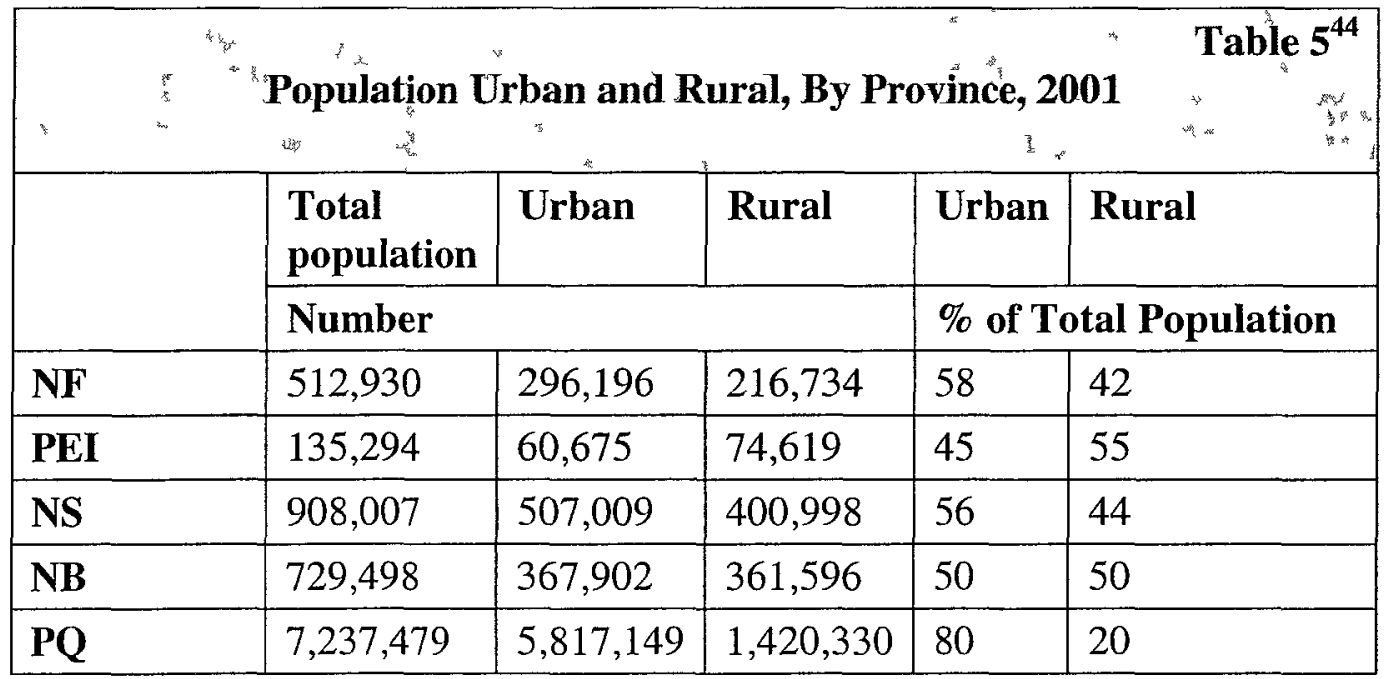

43 Rural versus urban population influences relative efficiency of program and service delivery, in that public services such Medicare, hospital services, schooling, infrastructure development are dispersed over a larger as compared to in a larger urban settıng

$44 \quad$ Note Rural population refers to persons living outside centres with a population of 1,000 and outside areas with 400 persons per square kilometre Previous to 1981, the definitions differed slightly but consistently referred to populations outside centres of 1,000 population Source Statıstics Canada, Censuses of Populatıon, 1851-2001 URL http //www40 statcan ca/101/cst01/demo62e htm Accessed Febiuary 24, 2007 


\begin{tabular}{|l|l|l|l|l|l|}
\hline ON & $11,410,046$ & $9,662,547$ & $1,747,499$ & 85 & 15 \\
\hline MB & $1,119,583$ & 805,321 & 314,262 & 72 & 28 \\
\hline SK & 978,933 & 629,036 & 349,897 & 64 & 36 \\
\hline AB & $2,974,807$ & $2,405,160$ & 569,647 & 81 & 19 \\
\hline BC & $3,907,738$ & $3,309,853$ & 597,885 & 85 & 15 \\
\hline
\end{tabular}

\section{Financial Capacity}

From a financial administration perspective, there are key differences between small provinces' ability to adopt free-standing international policies, and larger provinces better able to pursue interests in relatively autonomous ways. In the case of New Brunswick, dependency on federal funding through regional equalization payments; special disbursements through bilateral agreements ${ }^{45}$ and regional development incentives such as provincial and Atlantic region funding through the Atlantic Canada Opportunities Agency (ACOA) promotes an acquiescent provincial culture. The net effect here is that unless there is an overriding ideological or practical reason for the New Brunswick government to adopt policy orientations at odds with the federal government, ${ }^{46}$ it supports the federal position and does not adopt competitive measures and countermeasures against, for example, provinces like Québec.

This predilection to collaboration will be elaborated in the section dealing with New Brunswick's participation in La Francophonie, where the strategic value of New

\footnotetext{
$45 \quad$ Such as the New Brunswick-Francophonie Agreement.

46 For example, in 2005 the New Brunswick government took a highly publicized contradictory position to the national daycare initiative proposed by the Paul Martin led federal government on ideological and province-specific grounds.
} 
Brunswick's iecognition of the federal jurisdiction in international matters contrasts with the practice of other provinces adopting a more strident approach to defending the provincial jurisdiction in international relations As a Deputy Minister noted, "In the previous government the Premier liked to say that New Brunswick shouldn't walk around with the Constitution in its back pocket, 47

There 1s no guile to this economic imperative, officials at the Department of Foreign Affars question whether cooperation and collaborative relations have financial undertones.

Rather than relying exclusively on cooperative relations with the Government of Canada on international relations, New Brunswick should seek to be cooperative in certain sectors and competitive in others. In fact, New Brunswick is positioned to benefit from competition in its international affarrs; the natıonalıst government in Québec (for example) helped focus the attention of the federal government onto other provinces. If cooperation is simply another way of just asking for money, we must find another way. ${ }^{48}$

The plague of fiscal federalısm has brought serious consequences for New Brunswick. As one of the smallest provinces, its ability to avold "asking for money" simply does not exist Simeon and Nugent point out that the federal government's comparatively large spendıng power and ability to run budgetary surpluses provide "a constant incentive for Ottawa to intervene in areas of provincial jurisdiction, often in capricious and uninformed

47 Interview, John Kershaw, Deputy Minister, Department of Education, May 3, 2007

48 Interview, DFAIT official, Anonymity requested, Fredencton, February 17, 2004. 
ways. ${ }^{, 49}$ They also note that the same dynamic places the provinces in the situation of having to approach the federal government for money to support the services they provide and the regulations they enforce while at the same time demanding diminished conditionality in return for those resources.

It is precisely this conflicted approach that underpins New Brunswick's relationship with the federal government.

Also from the financing perspective, it is commonly known in Canadian government circles that large provinces pursue their international priorities through the establishment of foreign offices, Premier and Ministerial missions, and extensive in-market promotional campaigns, while "the smaller provinces are more likely to spend scarce dollars on partnership arrangements in regional promotions (e.g. 'Atlantic' tourism promotion in the US) or with the federal government, and to target their direct international representation and advocacy to specific regional issues (e.g. potash sales; foreign overfishing). ${ }^{.50}$ If size equals capacity, New Brunswick's lot is far diminished than that of its provincial brethren, leading Savoie to point out that its asymmetry and relative dependence on Ottawa comes while Ottawa continues to support policies that inherently favour central Canadian provinces such as Ontario and Québec. ${ }^{51}$

$49 \quad$ Richard Simeon, Amy Nugent, "Parliamentary Canada and Intergovernmental Canada: Exploring the Tensions," in Herman Bakvis, Grace Skogstad, (eds.), Canadian Federalism: Performance, Effectiveness, and Legitimacy, $2^{\text {nd }}$ ed., Toronto: Oxford University Press, 2008: 104.

50 Douglas A. Brown, "A Baseline Study of International Relations and the Federal System," (revised draft), Kingston: Institute of Intergovernmental Affairs, Queen's University, December 1999: 38.

$51 \quad$ See Savoie, Pulling Against Gravity, 2001. 
Savoie and earlier New Brunswick academics such as Hugh Thorburn ${ }^{52}$ have always maintained that systemic asymmetry between the provincial and federal government has transformed New Brunswick and the Maritime region into "supplicants" of the federal government, and perpetuated economic dependency on Ottawa. Watts makes a similar point in noting that asymmetry between small and large orders of government in a federation "lies in the relative power and influence within these federations of the larger regional units, especially where one or two dominate, and in the relative powerlessness of the smallest member units." 53

\section{Gaps in Paradiplomatic Studies}

Most literature naturally emphasizes the role of central governments in international relations and it may seem there is little on the international activities of provinces. The truth of the matter is that there is a substantial body of literature concerned with the provincial conduct of extra-territorial relations, also known as "paradiplomacy," including work by Denis Stairs, James Groen, David Dyment, Christopher Kukucha, Gordon Mace, André Lecours and others (mentioned in greater detail in Chapter 2). ${ }^{54}$

52 See Hugh G. Thorburn, Politics in New Brunswick, Toronto: University of Toronto Press, 1961.

53 Watts, Comparing Federal Systems, 1993: 63.

54 The conference from May 13-15, 2004 in Québec City titled "Les livres blancs: outils de gestion de la politique étrangère?", organized by the École nationale d'administration publique, Université du Québec reflected wide interest in elements of Canadian foreign policy administration, including consideration of provincial international interests. Of comparable value was the conference on "Polycentric Governance?: Sub-national Governments and Foreign Policy in an Age of Globalization," which took place in Ottawa from June 6-7, 2006, organized by the National Capital Branch of the Canadian Institute for International Affairs (CIIA) in 
Other scholarly contributions such as those by Rocher and Smith and Ronald L. Watts ${ }^{55}$ dealing with new trends in Canadian federalism, annual publications on the state of the Canadian federation coordinated by the Institute of Intergovernmental Relations (IIGR) at Queen's University, demonstrate interest in the intersection between paradiplomacy and the Canadian system of federalism. To date though, most studies dealing with provinces' international affairs focus on large, resource-rich provinces such as Québec, Ontario, Alberta and British Columbia, and exclude consideration of challenges faced by smaller, resource-poor jurisdictions such as those in Atlantic Canada. This omission, however, is understandable for a few reasons.

Conducting research and data collection on the international activities of small Canadian provinces is difficult, and constitutes a challenging research prospectus. Reasons why conducting research on small provinces like New Brunswick is difficult include:

a) Smaller provinces' tendency to pursue interests through undocumented and spontaneous (rather than strategically planned) initiatives and informal working relationships;

b) Lack of broad-based intergovernmental engagement on international activities; and

partnership with the Norman Paterson School of International Affairs, Carleton University, and Royal Institute for International Relations.

55 See François Rocher, Miriam Smith, (eds.), New Trends in Canadian Federalism, $2^{\text {nd }}$ edition, Peterborough: Broadview Press, 2003; and Ronald L. Watts, The Federal Idea and its Contemporary Relevance, Kingston: Institute of Intergovernmental Relations (IIGR), 2007. 
c) Lack of centralized record-keeping, policy documents and/or delegated government entities responsible for the identification, pursuit and acquisition of interests.

An example of the non-systematic character of the Province's international activities is evident from its partnership with the Institute of Public Administration of Canada (IPAC) on projects such as the international development project in Northern Cape Province, South Africa. While discussing this undertaking, one ISWG member stated under condition of anonymity that the initiative had little functional value to the Province's international objectives. Rather, the participating government official was noted to have harnessed departmental resources to support the "pet project." While the project had normative value in the area of governance capacity building, it was generally observed that metrics or key performance indicators to demonstrate quantifiable return on investment for the Province was difficult to pinpoint, reinforcing the notion that certain policy initiatives may be guided more by personal aspirations rather than clearly-defined policy objectives. In this light, the vulnerability of New Brunswick's agenda and policies to individual interpretation and actions provides an additional and dynamic factor for consideration. ${ }^{56}$

In their study of Canadian provincial international policy, Elliott Feldman and Lily Feldman limit their study to Ontario, Québec, Alberta and British Columbia. They clarify the reasons for this exclusion, "We have focused on these four provinces because they are the most active abroad. In structure, content, and purpose, the other provinces are much 56 Anonymous, Interview, Fredericton, April 14, 2009. 
less visible and their activities are somewhat spasmodic and uncoordinated." ${ }^{57}$ In the case of New Brunswick (prior to the release of its International Strategy in 2004) this "spasmodic and uncoordinated" approach may have rendered study of its international policies highly difficult, if not impossible, given the lack of centralized policies on record-keeping for activities outside of Canada.

This shortfall of information is another factor which suggests the manner in which small provinces manage their international affairs is less systematic and rational than larger ones. Although provinces may have some areas of limited autonomy in their international affairs as the result of the internationalization of those policy areas, this does not mean that the institutional and administrative structures to organize, systematize and record that information have similarly evolved. While it is convenient to describe smaller provinces' international activities as spasmodic and uncoordinated, it is the absence of centralized record-keeping, reporting and academic oversight that makes analysis difficult, therefore giving the appearance of un-coordination.

The lack of rigid record-keeping among smaller provinces may also have to do with the perception that provincial jurisdiction in international relations is only peripheral and indirect, and therefore does not require the rigidity in performance reporting expected by the public as in other core areas of provincial program and service delivery, such as health, education or social services, for which information is conveyed in departmental annual reports, policy transparency and NGO engagement. Moreover, the international $57 \quad$ See Elliott J. Feldman, Lily Gardner Feldman, "Canada," in Hans J. Michelmann, Panayotis Soldatos, (eds.), Federalism and International Relations, Oxford: Oxford University Press, 1990: 206). 
affairs of small provinces may appear to lack coordination or strategic orientation given that provinces with comparably ruralized populations tend to focus their formallyarticulated policies and efforts on domestic affairs for practical and political reasons which may, as argued in Chapter 2, encourage elite involvement. After all, in a small province in which electoral support is won and lost on the execution of grassroots policy, what government dare publicly expend political capital on international relations at the risk of taking care of business at home?

Does lack of information constitute a good reason to ignore New Brunswick's international policies? In the view of this dissertation, the answer is "no." Despite the difficulties associated with researching this self-professed "have not" province, this dissertation explores New Brunswick's international policies to fill a void in the study of Canadian provinces. Perhaps more importantly, in exploring how this small dependent province pursues its international policies, we gain a deeper appreciation of how international relations have changed with the entry of large and small regional orders of government to the world stage. We also gain a deeper understanding of how provinces in federations may pursue collaborative intergovernmental relations with their federal brethren as a means to advance their own parochial interests and legitimize their pursuit of interests outside the confines of the nation-state.

Prior to 2003, New Brunswick's pursuit of international objectives appeared to consist of a compendium of sundry interests seemingly disconnected from one another and lacking coordination. This policy orientation may be partially explained by a former New 
Biunswick Secretary to Cabinet who noted that, "Tiaditionally, in New Biunswick, the Premiess have had a direct influence on how inteinational matters are pursued And since each Premier is different, each one peisonalized the file to suit their pieferences "58 He further pointed out, "Each of the four elected Piemiers of recent memory" have put their stamp on New Biunswick's internatıonal affaits in a unique and highly personal way,"60 the significance of which is reflected in the lack of an institutional orientation of the province's international activities

\section{Why Cooperate with the Feds?}

While larger provinces such as Alberta, whose economic resources give it a strong position from which to pressure the federal government for concessions in various areas (such as promotion of an Alberta office in Washington despite protestations dunng the Chrétien administration), New Brunsw1ck's generally cooperative approach with the federal government has two purposes One is to maximize any help the federal government may provide to the province for pursuit of its international interests and Internatıonal Strategy, which may include measures such as gathering and sharing of strategic market intelligence, generation and transmission of qualified business leads in trade and investment attraction, fairness in the granting of temporary visitor visas (TRVs) to foreıgn nationals to come to Canada, and assistance in planning New Brunswick missions to fore1gn countries

\footnotetext{
58 Interview, Kevin Malone, Secietary to Cabinet, Executive Council Office, Province of New Brunsw1ck, Fredericton, January 26, 2004

59 Louis Robichaud, Richard Hatfield, Frank McKenna, Bernard Lord

60 Interview, Malone, January 26, 2004
} 
The second purpose is that New Brunswick cooperates with the federal government to offset or counterbalance the relative autonomy and province-building imperative pursued by largeı provinces, which is seen by some federal politicians and bureaucrats as eroding their primacy in representing Canada on the whole on the world stage. In this way, a strong New Brunswick on the international stage that is supported by the federal government, and that in turn supports Ottawa's role, ensures that a strong Québec (for example) does not pursue a foreign policy that dimınıshes the view that Ottawa speaks for all of Canada in international relations. Furthermore, New Brunswick's support of the federal government in international affarrs helps offset the danger than some provinces realıze disproportionately greater success on the international stage to the detriment of the others in terms of, for example, becoming preferred or exclusive destinations for foreign investment, economic in-migration and tourısm, in effect, asymmetric province-building.

Power, influence, capacity and asymmetry play key roles in understanding New Brunswick's international policies and practices, and as such, cooperative approaches support the view that "Important distinctions must be made among the provinces." White also supports the view that institutional size is an important feature and that although scholars and public officials are aware of the constraints and opportunities that jurisdictional size present, "[.. ] the consequences of size for comparative analysis of Canadian governmental institutions have been seriously under-appreciated." 62

${ }_{61}$ Douglas A. Brown, "A Baseline Study of International Relations and the Federal System," (revised draft), Kingston: Institute of Intergovernmental Affarrs, Queen's University, December Brown, 1999: 38

$62 \quad$ Graham White, "Big is Different From Little: On Taking Size Seriously in the Analysis of Canadian Governmental Institutions," Canadian Public Admintstration, 33(4), 1990. 526. 
The need to understand international interests of smalle1 provinces will be increasingly important as all provinces vie for greater autonomy from the federal government, especially in policy areas of provincial jurisdiction that are becoming increasingly internationalized For example, combining the influences of paradiplomacy, provincebuilding and New Public Management (NPM), the Province of Nova Scotia created Nova Scotia Business Inc. (NSBI), an arm's length government agency responsible for pursuing FDI to the province ${ }^{63}$ The 2009 Throne Speech of the Government of Newfoundland and Labrador demonstrated a new strain of belligerence towards the federal government, with Premier Danny Williams indicatıng that his administratıon was prepared to go it alone on the international stage if required despite the fact that like New Brunswick his Province is of modest financial means. ${ }^{64}$

Perceived unequal treatment of the Province in international affarrs has not gone unnoticed by New Brunswick government officials. As noted by an officer in the

63 "The concept of Nova Scotia Business Inc., a private-sector-led business development agency, was first introduced in 2000, with the release of Opportunities for Prosperity, the Province's economic growth strategy. In November 2001, NSBI became fully operational and officially embarked on its five-year mission by helping existing businesses expand and attractıng new investment to Nova Scotia." Province of Nova Scot1a, Crown Corporation Business Plans for the Fiscal Year 2004-2005, Nova Scotia Business Incorporated, Business Plan 2004-2005: 57.

64 "Newfoundland and Labrador is not convinced that the current Federal administration, having ignored our best interests when developing domestic policy, will do any better in representing our best interests when developing foreign policy. If the current Federal Government is not prepared to represent the best interests of provinces like ours, then we as a province will protect our best interests ourselves. To lower tanff barriers to our exports while safeguarding our fish stocks and securing markets for our seal products, we will speak up on our own behalf on the international stage and work to effect progressive agreements that take our best interests fully into account." Speech from the Throne, $2^{\text {nd }}$ Session of the $46^{\text {th }}$ General Assembly of the Province of Newfoundland and Labrador, March 25, 2009: 3. 
Department of Business New Brunswick which is responsible for trade, investment and business development functions,

An example of our difficulty dealing with the Government of Canada relates to the way trade leads are handled. In the past, we've had a difficult time accessing the same sort of information regularly received by provinces like Ontario and Québec. We don't want special rights when we approach the federal government for fairness in trade lead generation and sharing. We just want a level playing field and the same opportunities available to the larger provinces. ${ }^{65}$

Additionally, there are concerns that federal Foreign Service Officers may be naturally more inclined to think and approach issues from a subconsciously big-province interest perspective, even if they don't openly favour or prefer anyone, in areas such as: support for ministerial visits; issuance of visitor and student visas; conveyance of intelligence with respect to market opportunities; tourism promotion and promotion of immigration. Cole, Kincaid and Parkin make the point that most Canadians tend to self-identify with their provincial rather than federal identifies, which by extension might suggest that regional loyalties play a detrimental effect on New Brunswick's dealings with DFAIT given the low numbers of New Brunswickers in the Canadian Foreign Service. ${ }^{66}$

65 BNB, Interview, Anonymous, Fredericton: February 17, 2004.

66 See Richard L. Cole, John Kincaid, Andrew Parkin, "Public Opinion on Federalism in the United States and Canada in 2002: The Aftermath of Terrorism," Publius, Vol. 32, No. 4, The State of American Federalism, Oxford University Press, 2001-2002, Autumn 2002: 130. "This finding also reflects the much higher public support for the provincial as opposed to [italics added] the federal government in certain provinces, especially Alberta and Quebec, where federal policy is often construed by provincial leaders as contrary to provincial preferences. [...] Respondents from the comparatively less well-off Atlantic provinces, which receive the highest per capita fiscal transfers from the federal government, showed not only the highest support for the federal government, but also higher support for the federal government than provincial government." 
Concerns are also raised that the federal government has a tendency of developing and funding programs that New Brunswick simply cannot access as a result of its diminished comparative financial capacity. For example, despite the existence of a FederalProvincial Interchange Program with the Department of Foreign Affairs and International Trade, few New Brunswick civil servants participate due to simple factors such as cost of living variances between New Brunswick and the National Capital Region. During discussions with provincial officials considering participation in the Interchange Program in 2005, a frequently-occurring concern had to do with the Province's apparent unwillingness to offer salary supplements to scale provincial salaries to the appropriate federal level appropriate for living in Ottawa at a level consistent with New Brunswick. Similar concerns regarding ability to finance provincial participation in federal programs related to international affairs arose when New Brunswick considered participating in the F/P/T co-location program, in which provinces contribute $\$ 250,000$ to $\$ 300,000$ to establish provincial offices in federal diplomatic missions abroad.

\section{Research and Organization}

\section{Sources}

Given that no substantial research has been attempted in this subject matter area, primary source materials were used extensively, including: publications from various ministries in the Government of Canada and Government of New Brunswick in the form of speeches, news and media releases, annual reports, white papers, position papers and other strategic 
documents published by government including statistical data related to trade and investment volumes, population and various aspects of demography (ex. urban/rural population distribution, linguistic affiliations, ethno-cultural diversity). Other sources of primary source information include mainstream media news reporting (not editorial) through newspapers and radio.

Another source of material for this dissertation is heuristic in nature, drawing from my experience working on New Brunswick's international policies and helping develop its International Strategy as Senior Policy Advisor with IGA. Such a heuristic approach required an objective and systematic re-examination of the process used to research and design the International Strategy, engage in its implementation, and pursue analysis of its success and failures. Despite the pitfalls inherent to heuristics, which seeks to inform the analysis of policy through reliance on personal experience, insight and retrospection, tremendous value can equally be derived given that "in heuristic research the investigator must have had a direct, personal encounter with the phenomenon being investigated $[\ldots]$ unlike phenomenological studies in which the researcher need not have had the experience, the heuristic researcher has undergone the experience in a vital, intense, and full way. ${ }^{, 67}$

67 Clark E. Moustakas, Heuristic Research: Design, Methodology, and Applications, $2^{\text {nd }}$ Ed., USA: Sage, 1990: 14. While I questioned my ability to objectively use my experiences with the subject matter in a critical manner, which may in fact result in the repudiation of my own work, I was inspired by Moustakas' reminder that, "The heuristic research process is not one that can be hurried or timed by the clock or calendar. It demands the total presence, honesty, maturity, and integrity of a researcher who not only strongly desires to know and understand but is willing to commit endless hours of sustained immersion and focused concentration on one central question, to risk the opening of wounds and passionate concerns, and to undergo the personal transformation that exists as a possibility in every heuristic journey." Ibid. Insofar as these possible 
Secondary sources of literature employed in this study were, for the most part, employed to develop the conceptual and theoretical framework into which primary source data was imputed. These secondary sources of literature include articles in scholarly and refereed journals; independent, co-authored and edited volumes of a scholarly character; and opinion or editorial content from regional and national newspapers and news magazines.

The proliferation of web-based document archiving resulted in the use of the Internet for accessing various primary and secondary source literature and data-sets. Websites from which documentation was accessed include citations indicating the URL and date of access.

Conversational and telephone interviews ${ }^{68}$ were conducted with middle to senior-level provincial and other government officials who willingly participated in the interview process and were given the option of having their citations having source disclosure or anonymity. Given the critical nature of this dissertation and the potential fall-out for bureaucrats speaking "on the record" with respect to highly-politicized policy issues, many interviewees requested anonymity. The paranoia and fear observed, however, was greater than anticipated, with several interviewed participants hesitant to even sign the standard consent form that was developed as per Carleton University's Ethics requirements for fear that any paper trail could lead to troubles. Prior to inclusion of wounds, I was jokingly warned by a close government colleague that I may be making a "career limiting move" by critiquing my own work, as well as directing attention to New Brunswick's policy implementation foibles. Only time will tell for certain if those words were prophetic.

68 In accordance with standard accepted practices for academic investigation, interviews were conducted pursuant to Carleton University's Policies and Procedures for the Ethical Conduct of Research. 
interview materials in the dissertation, a detailed form concerning the incorporation of live subjects was created with the assistance of Carleton University's Ethics Committee, for which final approval was extended. Given the valuable nature of their insight, they have been included in this dissertation, although for veracity purposes their observations should be considered as anecdotal, and not open to independent verification.

With respect to accessing government publications and internal-to-government documentation, given the potential conflict of interest with respect to my employment in the New Brunswick Public Service as principal architect of the Province's International Strategy, authority to access literature cited was sought and received by the Secretary to Executive Council and the Deputy Minister of Intergovernmental Affairs in 2004. I also ensured that my immediate managers and Deputy Ministers were advised of the nature of my dissertation topic, and assured that potential conflicts would be managed in a transparent and ethical manner. This point is significant given the challenge of accessing documentation, questioning colleagues, and filing Access to Information requests "against" my own department and colleagues, ${ }^{69}$ and citing correspondence that I had drafted and influenced.

69 While Access to Information legislation is designed to keep government open and accountable to the general public through the interchange of unclassified information, the culture within government is to view requests in an adversarial, "us versus them" manner, as information released under Access to Information legislation frequently ends up as grist for Legislative Question Period, in which the Opposition uses information gleaned to attack the political executive, and by extension, the bureaucracy. For example, see Carl Davies, "There'll Be No High-Priced, Wrap-up Dinner This Time," New Brunswick Telegraph-Journal, November 5, 2003. Based on information gathered under Access to Information, the then-Opposition Liberals levied personally injurious and politically damaging allegations against then BNB Minister Norm Betts for expenses incurred during a 2003 trade promotion event in New York, which resulted in great embarrassment for the Minister and senior bureaucracy at BNB. "Business New 
Chapters Layout

The dissertation is organized into five chapters, and the next several pages overview how main at guments earlier presented are advanced

Chapter One provides background and context for the dissertation's central assertions, and outlines the structure and main objectives sought

Chapter Two provides an overview of the literature and major concepts of relevance to this study, paying particular attention to the following five areas:

a) The rise of paradiplomacy;

b) Trends in Canada's constitutional history;

c) Canada's federal system;

d) "Province-buıldıng" and the Garbage Can Model of organizatıonal analysıs; and

e) Canadian provinces as international actors.

Brunswick Minister Peter Mesheau sald he's done away with the mission-ending dinner for politicians, civil servants and businesspeople that created so much controversy after the previous trade mission to New York City last year. The wrap-up dinner at that event, which took place at an Irish pub called Rosie O'Grady's, cost taxpayers $\$ 2,320$, including $\$ 770$ for wine, beer, and cocktals. All told, the bill came to approximately $\$ 90$ a head. When the issue was rassed in the provincial legislature, Norm Betts, who was then Business New Brunswick minister, explained he thought he was being frugal by only ordering a cheeseburger at the New York dinner. The opposition jumped on the comment, sarcastically referring to Mr. Betts' " $\$ 90$ cheeseburger" at every opportunity Mr. Mesheau has reduced the opportunity for the opposition to make political hay out of this trip by cuttıng out the dinner entırely." 
This chapter builds on scholarship that central governments are not alone in their claim to legitimacy on the international stage, and that this stage is shared with regional governments, especially when federations are involved. This is to say, the existence of the federal state creates a powerful rationale for the inclusion of regional governments on the international stage from a constitutional (assignment of jurisdiction) perspective and a practical (competence-based) perspective. Some of inequities between various Canadian provinces are further discussed, which serves as the backdrop to discussion of the New Brunswick experience in the next chapter.

Chapter Three offers a detailed view of the province of New Brunswick from a general perspective, and provides a comprehensive look at various action priorities advanced by New Brunswick's International Strategy and initiatives that were put into place. Drawing from this, the design, implementation and evaluative techniques employed with respect to New Brunswick's International Strategy are examined.

Chapter Four looks at three specific areas of New Brunswick's international activities: trade promotion and investment attraction, immigration and participation in $L a$ Francophonie, each of which demonstrates a case for a sharing of intergovernmental jurisdiction. These issues have been chosen for analysis for three reasons. First, they involve multiple points of contact between both orders of government in order for successful action and coordination of measures, and have no clear-cut lines of jurisdiction prescribed in the Canadian Constitution. In the area of immigration for example, while the federal government has jurisdiction over security and visa granting protocols, the 
provinces have a vested interest in the attraction, settlement and servicing of new immigrants, as well as management of nominee schemes to service strategic sectors of the local economy. Second, given the federal-provincial implications of these policy issues, they allow us to look closer at how executive federalism and bureaucratic relationships influence advancing each order's interests, especially given their recent internationalization. Third, especially in the case of New Brunswick's membership to La Francophonie, it is possible to examine how the strategic objectives of both orders of government can be pursued through intergovernmental cooperation on policy issues, such as when Canada-New Brunswick cooperation in La Francophonie was used to counteract the Province of Québec's aggressive sovereignty assertions and claims to an independent foreign policy in the 1970 s.

Within each of these policy areas, the following three topics are explored: a) activities pursued by New Brunswick; b) activities pursued by the federal government; and c) policy intersections and collaborative mechanisms. With respect to the internationalization of constitutionally-ascribed provincial policy domains and tensions that may arise from those policy intersections and instances where both orders of government must work with one another Feldman and Feldman note, "[...] the political content and circumstance of developments in the 1970s and 1980s make the overall direction and thrust a new dimension in the international system." ${ }^{, 70}$ Hocking similarly

\footnotetext{
$70 \quad$ Feldman, Feldman in Michelmann, Soldatos, 1990: 177.
} 
notes that the 1970 s and 1980 s were marked by growing internationalization and "expanding foreign policy concerns of regional governments.",

Chapter Five is the concluding chapter, and employs the conclusions drawn in the previous chapters to revisit the initial assertions made in the Main Arguments section of Chapter One. It ties together analyses related to New Brunswick's international policies and practices to answer questions deriving from the assertions that New Brunswick's International Strategy does not reflect a significant departure from existing practices; there are grounds on which to re-examine the concept of "province-building;" the Province's approach to its international relations is consistent with the general principles of Canadian federalism; and that New Brunswick's international aspirations are best served by its wholesale support of a continued strong role for the federal government in foreign policy matters.

Drawing on the issue overview provided in the previous chapter, Chapter Five also examines inter-and intra-institutional factors that influence the conduct of intergovernmental relations and executive federalism as they relate to New Brunswick's international policies. Attention is paid to organizational design factors such as the impact of corporatism versus silo approaches to policy management, the significance of human and financial factors, and management of relationships within and with partners outside the provincial government. Some attention is also paid to examining how New Brunswick may pursue present and future interests unilaterally, with the federal

$71 \quad$ Brian Hocking, "Regional Governments and International Affairs: Foreign Policy Problem or Deviant Problem?," International Journal, Summer 1986: 479. 
government, with othe1 reg1onal governments on a bilateral basis, thiough regional blocs, with foreign governments, and with supia-national organizations such as La Francophonie

Finally, this chapter provides a view of best practices and unique attributes of this particulai federal-provincial relationship along with a summary of significant findings, 1dentifies issues deserving future scholarly investigation, and provides a series of recommendations that the Province of New Brunswick may consider engaging in a very practical sense to continue towards the realization of its international goals and aspiratıons

\section{General Remarks}

As a committed public servant, engaged student of political science and native New Brunswicker, I pursued this dissertation topic in order to make a significant academic contribution to how we understand forces affecting New Brunswick's international policies, as well as provide insight into ways that the Province can optimize its future pursuit of international relations As globalization intensifies with exponential advances in information technology, interconnectivity and integration of the international marketplace, small provinces like New Brunswick are forced to take far greater account of what happens on the global stage in the formulation and articulation of domestic policy and identification of opportunities for growth In developing the Province's International Strategy, however, I came to appreciate the lack of any substantive scholarship on New 
Brunswick's international activities. At the same time I was suspicious of government's ability to provide meaningful solutions to this pressing issue on account of its inherently clumsy and awkward modus operandi, a sentiment famously expressed by Adam Smith in The Wealth of Nations.

This dissertation delves deeply into the inner workings of government and intersections where provincial and federal policy jurisdictions come into contact. Through analysis of these intersection points, this dissertation seeks to generate policy-relevant analysis and practical knowledge that might inform how New Brunswick can approach coordination of its international activities, as well assist in the amplification of efforts to fostering productive, meaningful intergovernmental relations in the area of international cooperation and inter-jurisdictional cooperation with the federal government.

Recent globalization has altered how regional governments determine their place in the world and the paradox of local issues being thrust onto the world stage has intensified. The influence and implications of many policy issues has had an impact on a state-tostate basis, and has reached downwards into the nation-state itself and its various orders of government. As the result of these changes, regional governments around the world have been thrust into the position of having to reconsider their place in their respective jurisdictions.

In 1973 Meekison noted that "The dispute over the jurisdiction of provincial governments in the area of international relations clearly illustrates not only many of the problems but 
also the dynamic nature of Canadian federalism." 72 Despite the federal government's pressure to assume for itself the majority of control over external affairs in the early days of Canadian confederation, Meekison pointed out that Canada's status as a sovereign nation which participates in international affairs resulted in "disputes between the national government and the provinces arose when the former began to exercise its authority in foreign relations. ${ }^{, 73}$ The issue has only intensified since then.

But while new social and economic international pressures exert themselves on all Canadian provinces, why are academic studies limited to the experiences of Ontario, Québec, Alberta and British Columbia? While exclusion of small provinces from such study was justified due to limited availability of research materials and lack of clarity regarding their international objectives, ${ }^{74}$ New Brunswick's attempts to develop and implement a formal International Strategy provides an excellent opportunity to explore how small provinces deal with international issues. ${ }^{75}$ These kinds of studies are important, not only to New Brunswick, but to Canada and the study of Canadian political science. As White points out, Canadians must understand how size-related issues relates

72 Peter J. Meekison cited in Howard Leeson; Wilfried Vanderelst, External Affairs and Canadian Federalism: The History of Dilemma, Toronto: Holt, Rinehart, Winston, 1973: iii.

73 Ibid.

74 See Feldman, Feldman in Michelmann, Soldatos, 1990.

75 On January 17, 2006 the Province of Manitoba released its own provincial international strategy entitled "Reaching Beyond our Borders," which outlined areas of interest and significance. As New Brunswick, the Province of Manitoba recognized the interplay between the historical role of the federal government in international affairs and the growing role for the provinces- "In the past, matters of foreign affairs, foreign aid, and international trade were in the exclusive domain of national governments. However, today's issues are so broad and diverse that we must look beyond our national governments to sustain and nurture our international relations." Province of Manitoba, Reaching Beyond Our Borders, Winnipeg, 2006: 3. 
to public policy: "If we are to understand many of the policies of greatest import to Canadians, we must come to grips with the context of provincial policy-making. And size is one of the most important contextual variables." 76

New Brunswick provides a strong case study given its small size and high degree of asymmetry to the federal government and many larger Canadian provinces. Conceptually, this study also adds to a growing area of interest to about federal states and how their constituent units seek opportunities on the world stage to directly articulate and pursue their own interests, either in cooperation with the national state, or on their own. While the activities of larger regional governments are well-studied, there is scant material on the activities of smaller ones. ${ }^{77}$

76 White, "Big is Different From Little," 1990: 550.

77 See Stairs, Royal Commission, 2003. 


\section{Chapter II: Thematic and Conceptual Overview}

Do Canadian provinces matter in international relations? It is both a simple and difficult question to answer. This chapter provides background context to this question, and overviews some of the dominant themes and concepts associated with the consideration of Canadian provinces as international actors.

\section{Background}

This Chapter surveys broad themes and concepts relevant to this study. It is organized into the following six sections that provide a broad-based framework into which the main lines of argument of this dissertation can be explored:

- Canadian provinces as international actors;

- The rise of paradiplomacy;

- Trends in Canada's constitutional history;

- Canada's federal system;

- Province-building and the Garbage Can Model of organizational design; and

- Canadian provinces as international actors. 


\section{Canadian Provinces as International Actors}

The argument that Canadian provinces can be international actors in their own right is takes root in the work conducted by Donald Smiley, whose research on Canadian federalism explored the non-hierarchical character of the federal-provincial relationship. Whereas he did not overtly comment on the international dimensions of the federalprovincial relationship, Smiley argued that "Provincial autonomy is necessary for the vigorous and effective implementation of public policy."78 This provincial autonomy functionally expressed in the form of robust provincial international affairs campaigns led Douglas Brown to argue that "For some decades now, the Canadian provinces have been active on the world stage." ${ }^{, 79}$ In 1999 then-Minister of Intergovernmental Affairs in 1999 Stéphane Dion pointed out that Canadian provinces are bona fide international actors in their own right, however he may have overstated the degree to which both orders of government harmoniously pursue their interests on the world stage. Indeed, whether Québec would have agreed with his observation below sets the stage for an interesting study:

78 Smiley's work on "The Rowell-Sirois Report, Provincial Autonomy, and PostWar Canadian Federalism," Canadian Journal of Economics and Political Science, 28, February, 1962 (p. 67), represents a significant contribution to the study of regional governments as actors in federal affairs, which would set the stage for his later and key contributions related to the international relations dynamic in works such as: Canada in Question: Federalism in the Eighties, 3rd ed., Toronto: McGraw-Hill Ryerson, 1980; Federal-Provincial Conflict in Canada," Publius: The Journal of Federalism, vol. 4, no. 3. Summer 1974; The Federal Condition in Canada, Toronto: McGraw-Hill Ryerson, 1987; "Territorialism and Canadian Political Institutions," Canadian Public Policy, (3) 1977, which were of great assistance in the preparation of this study.

79 Douglas M. Brown, "Provinces Have a Role in Canadian Foreign Policy," Federation: What's New in Federalism World-wide, 2002: 11. 
Our provincial, federal and territorial governments cooperate very actively in matters of foreign policy. In all international negotiations, the Government of Canada always ensures that Canada's negotiating positions reflect the expressed interests of the provincial governments. Mechanisms for consultation with the provincial governments have been in place for many years, work in an exemplary fashion, and may rightly be envied by the members of other federations. ${ }^{80}$

Canadian provinces have their own international agendas, and pursue those interests in a manner related to their size, resources and capacity. Differences between provinces and territories as disparate as Alberta, Nunavut and Prince Edward Island support the view that provinces should exercise greater autonomy in international matters to develop solutions to regional policy and governance issues. Watts notes, "Generally, the more the degree of homogeneity within a society the greater the powers that have been allocated to the federal government, and the more the degree of diversity the greater the powers that have been assigned to the constituent units of government." ${ }^{\prime 81}$ While I believe Watts did not have provincial international activities in mind when he wrote this, his observation that inter-provincial heterogeneity mandates different solutions different problems is constant, and is manifested in provinces' domestic and international pursuits, and therefore has great applicability to the questions explored herein.

In New Brunswick's case, a combination of economic weakness and linguistic heterogeneity finds expression in the province's international policies. Nonetheless, it

80 Stéphane Dion, "Collaborative Federalism in an Era of Globalization," Notes for an Address to the Institute of Public Administration of Canada (IPAC), Government of Canada- Privy Council Office, Ottawa, Ontario, April 22, 1999.

81 Ronald L. Watts, Executive Federalism: A Comparative Analysis, Kingston: Institute of Intergovernmental Relations, Queen's University, 1989: 35. This point will be emphasized later when discussing New Brunswick's policy of official bilingualism. 
should be remembered that all provinces and territories will, to some degree, seek to build their own capacity to act in a variety of sectors. In this way, Canada's interprovincial heterogeneity and the provinces' perceived need to support their residents both at home and on the world stage gives rise to three sets of questions that are dealt with in this dissertation. These three sets of questions have over-arching relevance to the four main questions outlined in Chapter 1, namely that: New Brunswick has no effective International Strategy to speak of; the International Strategy that was posited gives new relevance to the concept of "province-building;" New Brunswick is well-served by a strong federal government role in international relations; and the relevance of the Garbage Can approach to policy analysis. While the following three question sets have a narrower, more empirical range of underlying concerns, they influence each of the four major lines of argumentation advanced in this dissertation.

First, with respect to the intergovernmental pursuit of international priorities that have federal-provincial implications, what are the theoretical and practical policy considerations that define the intersection of federal and provincial areas of jurisdiction? In its international practices, how does New Brunswick balance its unilateral methods and modalities with efforts that demonstrate cooperation with the federal government? Can such efforts be viewed as genuine efforts to work in a collaborative fashion with Ottawa, or are they better conceptualized as efforts to discourage the federal government from thinking that inactivity in a given policy area is a rationale for the federal government to fill the vacuum, i.e. "jurisdictional creep?"82

$82 \quad$ For example in some federal systems, such as Australia, the central government has jurisdiction over areas that are in the purview of Canadian provinces, such as post- 
Second, how do the Government of Canada and Government of New Brunswick interact in a manner that recognizes the province's smaller financial and human resource capacity to ensure extension of equitable and beneficial services? For example, when foreign diplomats, political leaders and business leaders visit Canada, is New Brunswick included on itineraries and agendas? When marketing Canada as a destination to prospective immigrants, do federal immigration officials recommend some provinces as end destinations over others? When implementing programs and services that impact directly on provinces' international activities, how does the Ottawa administer initiatives

such as the Federal-Provincial-Territorial Interchange Program and Federal/Provincial/Territorial Co-location Program such that all provinces can participate? After all, just because Canada's larger (or wealthier) provinces can afford to participate in such initiatives does not necessarily mean they serve in the interests of all provinces and regions of the country.

Third, from the perspectives of bureaucratic politics, intergovernmental relations, policy development and province-building, how does New Brunswick's International Strategy and international policies help us better understand how this particular province has faced the challenges posed by globalization? Where policies developed and how are they implemented? What can we learn from evaluation of the Province's efforts?

secondary education. The federal government is then able to pursue horizontal policy integration of international foreign student attraction and marketing efforts with immigration and security clearance protocols. In Canada, while provinces are responsible for education-related issues, DFAIT created and runs an international education services and marketing unit, thereby blurring the lines of jurisdiction. 


\section{Previous Studies of Provinces and International Activities}

Stand-alone studies on the international activities of Canadian provinces are few, but provide both single and comparative case studies. Bonnie Kettner ${ }^{83}$ prepared a Master's thesis on the international policies of Ontario, Québec and Alberta (1980). Dehousse offers a comprehensive examination ${ }^{84}$ of international activities by component orders of government within federations. Feldman and Feldman offer the already-cited 1990 study on Canadian provinces in international relations. James Groen's 1995 doctoral thesis ${ }^{85}$ examines the intergovernmental and international relations policies of the provinces of Ontario and Alberta, and David Dyment used his 1996 doctoral thesis $^{86}$ to consider the role of the Ontario government as an international actor with ebbing and flowing degrees of international involvements. Given the highly activist approach Québec has taken with respect to its foreign policy, there is substantial scholarship on scholarship dealing with origins, directions and intergovernmental significance of Québec's international relations

83 Bonnie Raines Kettner, Canadian Federalism and the International Activities of Three Provinces: Alberta, Ontario, and Quebec, M.A. Thesis, Simon Fraser University, 1980.

84 See Renaud Dehousse, "Fédéralisme, asymétrie et interdépendance: Aux origines de l'action internationale de composants de l'Etat fédéral," Études internationales, Vol. XX, No. 2, June 1989, who argues that regional governments in decentralized federal systems vary in size, capacity and interests, and as a result find national expressions of foreign policy frequently lacking expression of their own social and economic interests.

85 James Groen, Intergovernmental Relations and the International Activities of Ontario and Alberta, Ph.D. Thesis, Queen's University, 1995, studies the international policies of Ontario and Alberta with the goal of demonstrating that a combination of transnational and domestic forces, the latter of which include Canada's own decentralized system and trends of strong regionalism, encourage regional governments to pursue their international interests; activities which by extension can be used to identify domestic forces and tensions at play.

86 David Dyment, The Reluctant Traveller: Understanding the International Activities of a Non-protodiplomatic Component Government: The Case of the Ontario Government from 1945 to 1995, Ph.D. Thesis, Université de Montréal, April 1996. 
policies. Balthazar, Bélanger and Mace ${ }^{87}$ for example, consider the province's foreign relations policies in a relatively singular fashion, with other significant works published by Balthazar, Bélanger and Bernier. ${ }^{88}$

With respect to the smaller provinces, the only significant work dealing with provincial international policies is Denis Stairs' examination into how Newfoundland and Labrador's international interests are reflected in Canadian foreign policy. ${ }^{89}$ In this study, Stairs assesses how Newfoundland and Labrador figures into federal foreign policy development, and studies the channels through which the province's interests are advanced.

Stairs' work represents the first serious attempt to examine a small Canadian province's international interests, but there is a significant methodological difference between his study and this one. Stairs seeks to understand "how the particular interests of Newfoundland and Labrador can be reflected, to the maximum possible degree, in the conduct of Canada's foreign policy,"

87 Louis Balthazar; Louis Bélanger; Gordon Mace, Trente Ans de Politique Extérieur du Québec, 1960-1990, Québec: Centre québécois de relations internationales/ Les éditions du Septentrion, 1993.

$88 \quad$ See for example, Louis Balthazar, "Québec's International Relations: A Response to Needs and Necessities," in Brian Hocking, (ed.), Foreign Relations and Federal States, London: Leicester University Press, 1993; Louis Balthazar, "The Quebec Experience: Success of Failure," in Francisco Aldecoa, Michael Keating (eds.), Paradiplomacy in Action, London: Frank Cass; and Luc Bernier, "De Paris à Washington: La politique internationale du Québec, Montreal: UQAM Press, 1996.

89 Stairs, Denis, "The Conduct of Canadian Foreign Policy and the Interests of Newfoundland and Labrador," Royal Commission on Renewing and Strengthening Our Place in Canada, March 2003.

$90 \quad$ Stairs, Royal Commission, 2003: 1. 
international policies from internal, intergovernmental and theoretical angles, and is not subsumed into the larger dynamic of Canadian foreign policy.

As this dissertation considers size as a factor influencing how small provinces may pursue their international interests as opposed to larger ones, a few words are in order. In Canada the notion of "asymmetric federalism" ${ }^{91}$ is generally associated with the federal government treating provinces in an uneven manner, extending to some provinces incentives and opportunities where a special need or purpose is served, and not to others. Tarlton notes, " $[\ldots]$ the notion of symmetry refers to the extent to which component states share in the conditions and thereby the concerns more or less common to the federal state as a whole. By that same token $[\ldots]$ the concept of asymmetry expresses the extent to which component states do not share in these common features." ${ }^{22}$ Benoît Pelletier, Québec's Minister for Canadian Intergovernmental Affairs and Aboriginal Affairs argued, "Asymmetry must not be trivialized or wrongly portrayed to the point of presenting it as a destructive phenomenon. On the contrary, it has proven to be a very useful tool for developing federative relations while taking into account the particular needs of Québec and the other provinces." 93

91 Alain Gagnon explores three definitions of asymmetrical federalism as they relate to Québec: a) states ought to protect communities; b) classical liberal conceptions of quality among citizens should be rethought; and c) asymmetry helps protect a plural democratic federal setting. See Alain Gagnon, "The Moral Foundation of Asymmetrical Federalism: A Normative Exploration of the Case of Québec and Canada," in Alain Gagnon, James Tully, (eds.), Multinational Democracies, U.K.: Cambridge University Press, 2001: 321-322. This volume contains several excellent chapters that cover other aspects of asymmetry in federal systems, both in terms of federalism theory and specific government systems.

92 Charles D. Tarlton, "Symmetry and Asymmetry as Elements of Federalism: A Theoretical Speculation," Journal of Politics, Vol. 27, 1965: 861.

93 Benoit Pelletier, Open Letter Published in The Gazette, November 7, 2004. 
Asymmetry, however, can also be seen as favouring larger and richer provinces at the expense of smaller ones. According to Gibbons, "Historically, the province [Alberta] has carried disproportionate weight within intergovernmental councils, and has played an active role in shaping the norms and practices of intergovernmentalism."94 Small provinces appear to have little bargaining power when negotiating with the federal government, or larger provinces for that matter. Van Loon and Whittington observe "For instance, Alberta, with its oil and gas, Quebec, with its hydroelectric potential, and Ontario, with its large population and stable industrial sector, have sources of economic wealth that enhance their bargaining strength at intergovernmental meetings."95 This asymmetry is of concern regarding international relations, in that it suggests larger provinces have more to bring to the table of international negotiations and pursuit of opportunity than do small ones.

New Brunswick

While Canadian provinces became very active in international relations in the 1960 s and 1970s (as earlier mentioned) New Brunswick's current participation derives from three systemic influences trends in the early 1990s: Canada's increased integration into the North American economy; the increase in foreign competition in commercial and economic relations; and increased Canadian penetration into international institutions all

94 Roger Gibbons, "Alberta's Intergovernmental Relations Experience," in Harvey Lazar, (ed.), Non-Constitutional Renewal: Canada: The State of the Federation 1997, Kingston: Institute of Intergovernmental Relations, 1998: 247.

95 Richard J. Van Loon, Michael S. Whittington, The Canadian Political System: Environment, Structure and Process, $\left(4^{\text {th }}\right.$ ed.), Canada: McGraw-Hill Ryerson Ltd., 1987: 526. 
of which involved inter-jurisdictional collaboration in areas relevant to the Province. While it is true that New Brunswick's enhanced role in La Francophonie predates the early 1990s, and that the province has had commercial relations with the New England region of the United States for decades, the 1990s represented a watershed time period in which the Province's international activities took on a more corporate, government-wide character. My discussions with provincial officials suggest that New Brunswick's international affairs are influenced at a high level by the following four broad factors adapted from the work of Bakvis and Skogstad. ${ }^{96}$ They are discussed below, not to unnecessarily clutter the discussion, but rather to provide additional context and background.

First, globalization has integrated domestic markets with the international political economy, which had meant that provinces face mounting pressure to pursue interests within domestic and global rules-based mechanisms such as the North American Free Trade Agreement (NAFTA) and various Memoranda of Understandings (MOUs) to which Canada is signatory. In turn some ${ }^{97}$ argue that provincial governments are pressured to actively campaign in favour of their own interests in the context of these agreements, especially where they have constitutionally assigned primacy, ${ }^{98}$ and may have to compete against other government actors. This factor is particularly relevant to the Chapter 1 hypothesis of a hybridized model of province-building when considering

96 Herman Bakvis, Grace Skogstad, "Canadian Federalism: Performance, Effectiveness, and Legitimacy," Canadian Federalism: Performance, Effectiveness, and Legitimacy, $2^{\text {nd }}$ ed., Ontario: Oxford University Press, 2008: 10.

Kershaw, Interview, 2004.

98 Kershaw, Interview, 2004. 
the provinces' international activities in this new age of globalization, and permeability between the "domestic" and the "international."

Secondly, the homogenizing effect of globalization ${ }^{99}$ and resultant pressures on provinces to safeguard their unique identity means provinces must project their culture outwards, and gives new relevance to the afore-mentioned federal consideration of asymmetric federalism to protect heterogeneous interests and identities. For example, Québec's aspirations of self-determination and protection of language is reflected in a robust foreign policy. New Brunswick's unique cultural and linguistic character impacts its international policies as well, as it is Canada's only officially bilingual jurisdiction and is home to English and French speaking communities. The need to safeguard the minority French-speaking population ${ }^{100}$ was reflected in a movement in the 1960 s to mobilize Acadian nationalism, and is manifested heavily in bilateral relationships with francophone jurisdictions throughout la Francophonie. By contrast, New Brunswick's Anglophone population lacks comparable mobilization and support in the form of federal and provincial programming dollars for the pursuit and promotion of linguistic nationalism.

A third factor relates to the Canadian government's effort to push international relations participation horizontally throughout provinces and territories while in the process

99 See Benjamin J. Barber, Jihad vs. McWorld: How Globalism and Tribalism are Reshaping the World, New York: Ballentine Books, 1996, regarding tensions between the modern and traditional world.

100 See discussion on Francophone psychological disempowerment in Réal Allard, Rodridgue Landry, "French in New Brunswick," in John R. Edwards, (ed.), Language in Canada, Cambridge: Cambridge University Press, 1998: 216. 
gaining suppoit for its own actions abroad by conducting F/P/T consultations. A numbe1 of support mechanısms have been particularly relevant for small provinces that involve shared-cost initiatıves through the Atlantıc Canada Opportunitıes Agency (ACOA). On the latter point, the now-defunct Canadian Centre for Foreign Policy Development (CCFPD) which operated within DFAIT engaged foreign policy experts from outside of government to work with departmental policy development. This push by DFAIT to obtain domestic sanction for its international activities is commonly referred to as the "domestication" of Canadian foreign polıcy. ${ }^{101}$

A fourth factor is normative, and suggests that provinces pursue international relations to provide social and economic benefits to communities. Duchacek notes although regional governments do not garner the same attention as do central governments that deal with international relations 1ssues such as war, peace, terror and diplomacy, provinces' activities have significant implications,

Their [non-central governments] impact on national foreign policy, involving decisive centre-to-centre relations, has remained modest: primarily they deal, so to speak, with the territorial bread. But, as every struggle for our daily bread, these internal concerns with their external dimension significantly affect the welfare of millions, their local and provincial leaders, and through them the complex interaction between domestic and fore1gn politics. ${ }^{102}$

101 "Domestication" of Canadian foreign policy is discussed in various works. Two insightful works are offered by Denis Sta1rs, 1978, and K1m Richard Nossal, "The Democratization of Canadian Foreıgn Policy?" Canadian Foreign Pollcy, 1(3), 1993.

102 Ivo Duchacek, "Perforated Sovereignties: Towards a Typology of New Actors in International Relations," in Hans J. Michelmann; Panayotis Soldatos, (eds ), Federalism and International Relations. The Role of Sub-national Units, Oxford: Clarendon Press, 1990: 2. 
At the same time, Lazar notes that in the case of federations, an additional layer of complexity or challenge requires some thought, in that "Authority is seen to be shifting upward to supra-national and international authorities, downward to regional and local governments and, perhaps most importantly, outward to the private sector and marketplace."103 The significance of these pressures suggests that as authority over international affairs moves "upwards" towards supra and international organizations and "downwards" towards regional governments and other local actors, the state will face a new round of questions regarding its international efficacy and utility.

\section{The Larger Provinces}

In order to provide some context to the differences between small and large provinces, the remainder of this section quickly reviews key facts and activities associated with the international policies of Québec, Ontario and Alberta. ${ }^{104}$

The Ministère des Relations intenationales (MRI) ${ }^{105}$ coordinates Québec's international relations, and plays a central role in managing Québec's international agreements, intergovernmental and international relations and participation in OIF. Its mandate is to safeguard and ensure Québec's perceived constitutional jurisdiction over international affairs, which includes ratifying treaties and advancing interests related to trade

103 Lazar, McIntosh, 1999: 5.

104 General information on these provinces' international activities was gleaned from the respective governmental websites, specifically from the ministries dealing with Intergovernmental Affairs and International Relations.

105 See Québec's Ministry of International Relations (MRI), URL: http://www.mri.gouv.qc.ca/en/index.asp. Accessed: September 2008. 
promotion, investment attraction, commerce, social programs, education and projection of culture, all through use of bilateral agreements, commercial offices abroad and participation in international social and commercial events.

Québec's international policies emerged from the "Quiet Revolution" of the 1960s. During this awakening of Québec nationalism then Minister of Education Paul GérinLajoie observed in 1965 the province's duty to "occupy its rightful place in the contemporary world and to ensure, both within and beyond its territory, that all necessary means are devoted to achieving the aspirations of the society that it represents." 106 More significantly, Gérin-Lajoie articulated what would become known as the "Québec doctrine" on international relations, which established that it and other Canadian provinces had the right to be active in international relations in areas that fall within the provincial jurisdiction, including entering into foreign treaties. As Mace, Bélanger and Bernier note, Gérin-Lajoie was arguing that "Québec is not a province like the others: the Québec state represents a distinct national community and must be able to represent it internationally on all matters related to this distinctiveness."107

The international implications and history of Québec's international policies and proclivities towards protodiplomacy, and the impact that had on New Brunswick's international policies as pursued within the envelope of strategic intergovernmental

106 Also known as the Gérin-Lajoie doctrine.

107 Gordon Mace, Louis Bélanger, Ivan Bernier, "Canadian Foreign Policy and Québec," in Maxwell A. Cameron, Maureen Appel Molot, (eds.), Democracy and Foreign Policy: Canada Among Nations 1995, Ottawa, Carleton University Press, 1995: 122. 
relations with the Government of Canada are covered in the section dealing with $\mathrm{La}$ Francophonie in Chapter 4.

Nationalist sentiments were expressed during Québec's 1966 election campaign, during which Jean Lesage's Liberals included the objective of "Making Québec a truly national State." This implies extending its powers and sovereignty, not only in terms of domestic policy, but also in the area of external relations and participation in supranational organizations such as the United Nations, OIF and UNESCO. To accomplish these goals, the Québec government allocates significant human and financial resources into commercial, government relations, immigration and cultural offices in global locations such as the United States, Latin America, Europe and Asia.

Dyment observes that "Compared to Québec which has conducted an often high profile pursuit of international contacts leading to friction with the central government, the international activities of Ontario, with its more congruent relationship with Ottawa, have attracted less attention."108 Ontario's Ministry of Intergovernmental Affairs (MIA) advises the Premier and Cabinet on international relations, with special emphasis on Ontario-US relations. While until the mid-1990s MIA managed Ontario's international relations, the majority of provincial international affairs are managed by the Ministry of

108 Dyment offers a strong research agenda in the area of provincial international activity, and relies on a multivariate explanatory framework for explaining the Province of Ontario's international policies. This multivariate approach was originally advanced by Panayotis Soldatos in "Cascading Subnational Paradiplomacy in an Interdependent and Transnational World," in Douglas M. Brown, Earl H. Fry, (eds.), States and Provinces, 1993: 45-64, and "An Explanatory Framework for the Study of Federated States as Foreign Policy Actors," in H.J. Michelmann, Panayotis Soldatos, (eds.), Federalism and International Relations, Oxford: Oxford University Press, 1990: 34-53. 
Economic Development and Trade (MEDT). Within the MEDT, the Office of International Relations and Protocol (OIRP) provides policy advice international matters, as well as Ontario's International Disaster Relief Program and the Ministry's International Marketing Centres.

New Brunswick informed development of its own International Strategy with research and government performance documents published by other provincial governments in Canada. For example, in 2000-2001 the Government of Ontario participated in 50 international missions and four Virtual Trade Missions to Singapore, Italy, California and Malaysia. It also participated in Team Canada mission to China with a delegation of 145 companies and $\$ 1.9$ billion in agreements. MEDT's 2000-2001 Annual Report shows that Ontario's Business Immigration Services program attracted 681 business immigrants, resulting in $\$ 105$ million in investments and 2,020 full and part-time jobs. ${ }^{109}$ These activities were taken into consideration by New Brunswick, and were discussed at regular meetings of the international working group assigned the task of feeding into what would become the Province's International Strategy.

Alberta's international affairs are managed by the International Governance Office $(\mathrm{IGO})^{110}$ of the Department of Government Relations. Provincial priorities are organized by geography and sector, with geographic interests in: Canada, the United States, Latin America, Europe and the former Soviet Union, Africa and the Middle East and Asia-

\footnotetext{
109 Ontario Ministry of Economic Development and Trade (MEDT), 2001-2 Business Plan.

110 See Alberta's Department of International and Intergovernmental Relations, URL: http://www.international.alberta.ca, Accessed: September 2008.
} 
Pacific; and sectoral interests in: oil, gas, timber, mineral and petroleum resource exports, energy-related equipment and services, cultural exchange, value-added primary resource materials, mining equipment and services, environmental management and information technology/telecommunications. To pursue agreements in these areas, Alberta makes extensive use of "twinning" agreements, economic partnerships, intercultural exchanges, and joint initiatives. ${ }^{111}$ Alberta's international strategy is outlined in A Framework for Alberta's International Strategies, which purports to be a foundation and framework for action, and claims to establish the province's vision and principles in international affairs; key activities and policies; the role of private-public partnerships; geographic and sectorbased international opportunities. As is the case with New Brunswick though, scant attention has been paid to determining the extent to which such strategies accomplish what they set out to do.

111 Twinning relationships are grouped into four categories:

Special relationships are multi-sectoral partnerships with a specific province or state within one of Alberta's priority countries. These are sometimes called sister province relationships designed to concentrate activities and cooperation, promote economic activity and cross-cultural awareness. Examples include: Kangwon (South Korea, 1974), Hokkaido (Japan, 1980), Heilongjiang (China, 1981), Tyumen, Khanty-Mansii, YamalNenets (Russia, 1990s), Jalisco (Mexico, 1999) Transboundary partnerships with American states are policy-oriented arrangements and help establish close working relationships with key decision-makers; manage cross-border matters; establish mechanisms for informal settlement and avoidance of disputes; access trade routes; and build alliances on transboundary issues.

Examples of these kinds of relationships include relationships with: Montana (1985), Idaho (May 2000) and informal relationships with Alaska and Washington. Economic Memoranda of Understanding (MOUs) are economic-oriented agreements whose purpose is to assist Alberta companies gain access to key foreign markets. Alberta has one economic MOU with Neuquen (Argentina, 1994). Governance twinnings are undertaken to assist other states or provinces improve their mechanisms of governance. Alberta has one twinning agreement with Mpumalanga (South Africa, 1996). 
This section has briefly reviewed the existing literature and discussion of the international activities of Canadian provinces, particularly large provinces, which influenced the development of New Brunswick's International Strategy. But important questions remain unanswered, especially about smaller provinces but also more general theoretical questions about what drives and shapes these activities. In the remainder of the chapter, we will explore a number of relevant literatures and theoretical frameworks that help us understand and answer these questions, starting with discussion of the rise of paradiplomacy in the study of provinces' participation in international affairs.

\section{The Rise of Paradiplomacy}

Inclusion of regional governments in international relations is the single-most important element underpinning this dissertation. This section unpacks some of the vocabulary, context and history associated with the shifting basis of analysis of international relations away from being driven largely by the central government, and towards regional government participation.

\section{The Impact of Nomenclature}

Assigning nomenclature in with respect to paradiplomatic activities is a politicallysensitive matter. With respect to this dissertation, the issue of terminology encompasses two broad areas: the actor; and regional governments' international activities. 
There is no universal nomenclature with which to collectively refer to regional governments. For the sake of simplicity, this dissertation refers to "provincial" or "regional" orders of government. Avoiding use of the term sub-national or subgovernmental levels of government steers clear of suggesting that the federal order of government is super-ordinate to the provinces. John Kincaid equates the term "paradiplomacy" with "subnational" diplomacy, both which implicitly suggest that provincial pursuit of international interests is somehow inferior or subordinate to the pursuits of the national government. ${ }^{112} \mathrm{He}$ therefore introduces the term "constituent diplomacy,"113 whose etymology associated with "con" implies the equal and parallel character of central and regional government international efforts, an irony considering the use of "subnational" in the title of one of the volumes in which Kincaid's work is found.

To be sure we understand the typology of provincial international relations considered, it is helpful to start with the big picture and work our way towards specificity. Brown and Groen (in reviewing the edited volume by Michelmann and Soldatos) note that the terminology associated with studying international relations and federal systems oftentimes includes confusing terminology and jargon (such as: paradiplomacy, protodiplomacy, macrodiplomacy, microdiplomacy, transnationalism and

112 See John Kincaid, "Constituent Diplomacy in Federal Politics and the NationState: Conflict and Cooperation," in Michelmann and Soldatos, Federalism and International Relations, 1990: 55-76. Also see John Kincaid, "Roles of Constituent Governments," Paper for the Forum of Federations seminar on "Foreign Relations of Constituent Units," Winnipeg, Canada, 11-12 May 2001.

113 Other terminology includes: non-central government, federated entity, constituent government. 
transgovernmentalism) which impede clear analysis. ${ }^{114}$ This dissertation is concerned with the first term, and to some degree, the strategic value to New Brunswick of Québec's pursuit of the second.

Paradiplomatic provincial activity involves the provincial conduct of foreign relations in parallel and concert with the central government. ${ }^{115}$ While Canadian paradiplomatic activities may at times experience friction when intergovernmental and interjurisdictional interest are concurrent or have mutually-exclusive objectives, they do not seek to supplant the federal government role on the world stage. They are conducted in addition to that of the central government, but are not subordinate, mirroring the original intent of Canada's founding fathers that both orders of government be equal within the folds of the state. On this point of concurrency, Roy makes the interesting point that the issue of leading and supporting in areas of concurrent jurisdiction is not cut-and-dry, and that with respect to the relationship between the provinces' subsidiary quality in relation to the federal government and the need for the federal government to abide by the notion of divided and responsible government:

114 Douglas Brown and James Groen, Review of Michelmann and Soldatos, Federalism and International Relations, 1990, in Publius, Vol. 24, No. 2, Spring 1994: 135.

115 Paradiplomatic and protodiplomatic tendencies of Flanders and Wallonia, Belgium are considered by Stéphane Paquin, "Paradiplomatie identitaire et diplomatie en Belgique fédérale: le cas de la Flandre," Canadian Journal of Political Science, Vol. 36, No. 3, July-August 2003: 621-642, a part of which is the "plus grand independence économique," at 625 . Rob Jenkins provides another example of how the centre exerts itself to ensure that proliferating diplomatic efforts by its constituent orders of government are held in control in "India's States and the Making of Foreign Economic Policy: The Limits of the Constituent Diplomacy Paradigm," Publius, Vol. 33, No. 4, Emerging Federal Process in India, Autumn 2003: 63-81. 
I would argue that these two principles advocate for greater provincial autonomy in the field of external affairs. Indeed, it would seem that federated entities are in a better position to correctly and efficiently negotiate the normative content of instruments directly affecting their exclusive sphere of competences. From the opposite angle, the principle of federal loyalty is calling for Canada's central government to respect provincial exclusive legislative competencies at home and abroad. ${ }^{116}$

By referring to "constituent diplomacy" Kincaid "avoids the implication that the activities of constituent governments are necessarily inferior, ancillary, or supplemental to the 'high politics' of nation-state diplomacy." 117 Soldatos notes that there are two distinct categories of paradiplomacy: while "global paradiplomacy" refers to when federated units become involved in issues that affect the entire international system, "regional paradiplomacy" is meant to focus attention on relationships forged by regional governments with foreign actors in response to local or regional issues of shared relevance, ${ }^{118}$ as might be the case with New Brunswick's participation in the New England Governors/ Eastern Canadian Premiers group (NEG/ECP) and Council of Atlantic Premiers (CAP).

116 Mathieu Roy, Treaty-Making Powers of Canadian Provinces: Revisiting the 1960s Debate in Light of Subsidiarity and Federal Loyalty, A thesis submitted in conformity with the regulations for the degree of Master of Laws, Graduate Department of Law, University of Toronto, 2005: 60-1.

117 John Kincaid, "Constituency Diplomacy in Federal Polities and the Nation-State," in Hans J. Michelmann, Panayotis Soldatos, (eds.), Federalism and International Relations: The Role of Subnational Units, USA, Oxford University Press, 1990: 74. Also see Iñaki Aguirre, "Making Sense of Paradiplomacy? An Intertextual Enquiry about a Concept in Search of a Definition," in Francisco Aldecoa, Michael Keating, (eds.), Paradiplomacy in Action: The Foreign Relations of Subnational Governments, USA: Routledge, 1999: 185-209.

118 Panayotis Soldatos, "An Explanatory Framework for the Study of Federated States as Foreign Policy Actors," in Michelmann, Soldatos, Federalism and International Relations, 1990: 37. 
Pioto-diplomacy, on the other hand, seeks to position provincial international policies as independent from the federal government, and is typically viewed by central governments as being dangeious or secessionary ${ }^{119}$ Québec's efforts to position itself in La Francophonie as per the Gérn-Lajore doctrine typify this approach, and are related to the "Québec-buldıng" agenda of both federalıst and sovereıgnıst governments

New Pressures on Federations

As with most federal systems, tensions and power struggles abound over which order of government is legitımated to do what in the international arena, mirroring their relationship within the federal system While Canada's federal government handles issues such as security and defence, immigration, trade dispute resolution and treaty-signing, provinces have responsibilities in other areas such as foreign direct investment (FDI), securing new export markets, attraction of foreign students and prospective immigrants and promotion of regional development, given their symbiotic and interdependent character Sometımes these interests brush up against each other and stımulate new ways of collaboration, at other times the policy collision is dramatic For example (and as will be discussed in Chapter 4 with the Modern School of India case example) while Ottawa has jurisdiction over security inspections and issuance of foreign student visas, provinces

119 See Ivo Duchacek, "Perforated Sovereınties Towards a Typology of New Actors in International Relations," in Michelmann and Soldatos, Federalism and International Relations, 199029 
seek to attract foreign students and attract immigiants to diveisify their population and strengthen local economies ${ }^{120}$ Simeon observes that,

Globalization, it is argued, places more constraints on national governments than on provincial or state governments [..] it is [also] a1 gued that it is provinces that have primary jurisdiction in many of the policy areas that have come to play a larger role in economic successlabour market policies, infiastructure, education, land-use planning, and other areas that affect the 'quality of life.' Thus, the balance is said to shift from the federal government as the primary guarantor of economic and social policy to the provinces. ${ }^{121}$

It is at this juncture, this "mish-mash" intersection of provincial and federal international interests, this dissertation seeks to make a contribution as it relates to New Brunswick and the role of smaller and weaker provinces in paradiplomacy.

A further analogy perhaps better illustrates how international intergovernmental involvement by federatıons as altered. Countries, like opposıng hockey teams, once faced off one another in adversarial yet predictable ways with the state as unitary actor. Globalization, however, has resulted in the equivalent of a "family skate." No longer are

120 "Under the BNA Act, immigration is a shared jurısdiction. The manner in which the Department of Citizenship and Immigration was created suggests that, if there was any consultation at all with the provinces in this important move, it was nominal." See Freda Hawkıns, Canada and Immigration: Public Policy and Public Concern, Montreal: McG1ll Queen's Press, 1998. 177.

121 Richard Simeon, "Important? Yes. Transformative? No. North American Integration and Canadian Federalısm," in Harvey Lazar; Hamısh Telford; Ronald L. Watts, (eds ), The Impact of Global and Regional Integration on Federal Systems: A Comparatıve Analysis, Montreal: McG1ll-Queen's University Press, 2003: 146. Stephen Brooks and Lydia Miljan posit in a similar light that “.. the forces of globalization have increased the exposure of all societies to the world around them and have increased the exposure of all societies to the world around them and decreased the capacity of domestic policy-makers to control what happens in their backyard." Public Policy in Canada: An Introduction, $4^{\text {th }}$ edition, Ontano: Oxford University Press, 2003: 17. 
individuals on the ice identifiable by uniforms and "rules of the game." Rather, there is chaos. All ages, shapes and abilities glide around the rink, focussed on their own interests Some do laps; some play chase, others fall. Everyone is everywhere and there are no rules.

This reflects the inherent disorder of today's international system and the fast-moving, anarchic system in which irrational decisıon-making sometımes prevails, however, theory has failed to keep up with the interconnectedness between the international and the domestic spheres, and this has affected the ability to undertake aggressive research agendas. Kukucha notes that analyses on paradiplomatic or perforated sovereignty ${ }^{122}$ have "fa1led to adopt any explicit theoretical framework" 123 Gourevitch suggested in 1978 that this interconnectedness and disjuncture would have implications "Instead of being a cause of international politics, domestic structure may be a consequence of $1 \mathrm{t}$. International systems, too, become causes instead of consequences." ${ }^{124}$ And in 1990 Kincard suggested,

[...] too much theory linked to international relations, international law, and international organizations is predicated on a unitary conception of the nation-state, and too many conceptual frameworks that acknowledge federalism and state and local government fall to take into account the growing interaction between local communities and a multitude of actors in the international arena. ${ }^{125}$

122 See for example Duchacek's works cited from 1986, 1988, and 1990.

123 Duchacek, 2003: 9.

124 Peter Gourevitch, "The Second Image Reversed- The International Sources of Domestic Politics," International Organization, vol. 32, No. 4, Autumn 1978: 882.

125 Kincaid in Michelmann, Soldatos, 1990: 64, cited in Fry, 1988. 12. 
Not much has changed in the past 20 years. Although this body of theory remains weak, the importance of the area is recognized by many current scholars. Hueglin notes that constitutional boundaries of federal states have significantly evolved, and globalization has challenged the traditional definition of what is federal and what is regional.

Constitutional rigidity is giving way to [...] greater flexibility [...] the relationship between federal and regional governments is taking on more balanced or even confederal characteristics. Territorial jurisdiction and representation are challenged by the rise of transborder and identity politics. The boundaries of national and regional policy domains are increasingly blurred by forces of economic globalization. ${ }^{126}$

Similarly, in 2001 Pal remarked that

[...] the traditional association between public policymaking and the territorial boundaries of the nation-state has been severely challenged in the last decade. Both the source of policy problems and their potential solutions now lie as much outside the boundaries of the state as they do within. ${ }^{127}$

The simultaneous localization and globalization of policy issues has understandably confused how provincial and federal officials pursue international interests. From this

126 Hueglin, 2003: 275

127 Leslie Pal, Beyond Public Policy Analysis: Public Issue Management in Turbulent Times, $\left(2^{\text {nd }}\right.$ edition), Canada: Nelson Thomson Learning, 2001: 63. Further, "This is not to say that states are irrelevant [...] The nation-state will remain as a fundamental organizing unit for contemporary industrialized societies, but the sort of control and dominance that they once enjoyed [...] is waning." (Ibid) 
confluence of factors comes the notion of "glocalization," an idea developed by Tom

Courchene that bi1dges the gap between the both worlds ${ }^{128}$

Canada is not alone in dealing with the challenge of permeable boiders and permeable intergovernmental jurısdiction flowing from an anachronıstıc constitution and limitations perpetuated by ineffective or inadequate regional representation in the nation's parliament. Regional governments in Europe face similar 1ssues, for example, the Belgian provinces of Wallonia and Flanders, the Spanısh regions of Catalonia and Basque country, and various German Lander governments enjoy varying degrees of autonomy in areas defined by their respective constitution as part of their jurısdiction. In Belgium, regional governments can enter into foreign treaties in policy matters within their jurisdiction, demonstratıng the importance of clearly defining the constitutional balance of power that exists between both orders of government.

This phenomenon, often called 'para-diplomacy', represents a manifestation of globalization, mainly the complexification of world politics through the multiplication and differentiation of actors. In other words, in acquiring international agency and developing international relations, regions become part of globalization rather than simply being acted upon by 1 ts processes. ${ }^{129}$

128 See Thomas Courchene "Glocalization: The Regional/International Interface," Canadian Journal of Regional Science, 18 1, Spring 1995; and R.J Holton, Globalization and the Nation-State, Palgrave MacMillan, 1998: 16.

129 Lecours, André, "When Regions Go Abroad Globalızatıon, Natıonalısm and Federalısm," Globalization, Mult1level Governance and Democracy: Contınental, Comparatıve and Global Perspectives, (Conference paper), Kingston: Queen's Unıversity, May 2002: 1. André Lecours, "Belgium," in Ann Lynn Griffiths, Karl Nerenburg, (eds.), Handbook on Federal Countries, 2005, Québec: McG1ll-Queen's Press, 2005. Also see 59-72, and several other examples including Australia, Germany, Indıa, Malaysıa, etc. 
From State Centricity to Paradiplomacy

While globalization has given new relevance to regional governments in modern times, insight into the origins of this devolutionary process provide context and shared lessons. Classical and structural realists viewed the international system as state-based. E.H. Carr and Hans Morgenthau are often credited as pioneers in subject of political realism, ${ }^{130}$ as is Waltz ${ }^{131}$ who established that an unstable international system created the preconditions for state centricity as a means to retain Hobbesian-style order and stability. The state's role in retaining security, self perpetuation and promotion of self interest was indivisible and wide-spanning, and international relations whose goals were advancing social, cultural and economic interests of regional governments were peripheral. ${ }^{132}$ Liberal interdependency advocates ${ }^{133}$ would argue that multiple stakeholders in a global civil society actively shape and influence international affairs, which can include other orders of government, and that this dispersal of authority results in a more interconnected, secure international system.

130 E.H. Carr, The Twenty Years' Crisis, 1919-1939, London: MacMillan, 1946; and Hans Morgenthau, Politics Among Nations: The Struggle for Power and Peace, New York: Knopf, 1948 are commonly viewed as the definitive texts on the realist view of nation-state primacy in international relations.

131 Kenneth Waltz, Man, the State and War: A Theoretical Analysis, New York: Columbia University Press, 1959 makes an important addition to the state-centric perspective through his work on structural realism and reinforcement of the state as basic building block of the international political system.

132 Morgenthau quotes Joseph Schumpeter, Business Cycles, London and New York: McGraw-Hill Book Company, 1939, vol. 1, p. 495, n.1- "[...] historic evidence points to the primacy of politics over economics, and 'the rule of the financier...over international politics' is indeed, in the words of Professor Schumpeter, 'a newspaper fairytale, almost ludicrously at variance with facts'." Morgenthau, Politics Among Nations, 1948: 63.

133 See Robert O. Keohane, Joseph S. Nye, Power and Interdependence, ed. 2, USA: Scott, Foresman, 1989; Immanuel Wallerstein, World-Systems Analysis, ed. 4, USA: Duke University Press, 2004. 
Ohmae wrote on the increasingly complex confluence between the globalization and the changing nation-state, noting that the state was "[...] an unnatural, even dysfunctional, unit for organizing human activity and managing economic endeavor in a borderless world." 134 Instead, he called for a "rethink" of the state, and in its place, an interpretative approach to international relations that considered regional economic zones on the basis of their presence in the international political economy. This represented a direct refutation of the Schumpeterian emphasis on politics as being the most important function of the state, and economic matters being secondary.

In his review of global federal systems, Lazar notes the impact of blurring lines between the international and the domestic- "[...] decentralization in Canada and India, for example, may have been initially motivated by domestic factors, but it is being reinforced by global and or regional integration." 135 While early advocates of the perforated sovereignty concept drew attention to the fact that global affairs tended to be state centric at the expense of considering other actors on the international stage, they failed to move past description;

Paradiplomacy, despite claiming that state-centered views of global politics are a 'gross distortion of reality,' also concludes that sub-national activity is limited to areas of "low politics' [...] Both frameworks also limited attention to institutional factors, such as constitutional issues,

134 "It represents no genuine, shared community of economic interests; it defines no meaningful flows of economic activity. In fact, it overlooks the true linkages and synergies that exist among often disparate populations by combining important measures of human activity at the wrong level of analysis." Kenichi Ohmae, "Rise of the Nation State," Foreign Affairs, 72, Spring 1993: 78.

135 Lazar et al, 2003: viii. 
bureaucratic capacity, party structure, political leadership, and cooperative federalism. $^{136}$

In this new world, Rosenau argues that there are a wide range of actors that are relevant, and whose pursuits define the larger understanding of international relations. ${ }^{137}$ Underpinning many of these pursuits, the realists argue is the concept of "self help." From this "self help," province-building perspective, the view that economics and social progress have new relevance for provinces helps bridge the gap between international relations theory and paradiplomacy. The Waltzian lesson that jurisdictions adopt self help measures to protect their interests is relevant to New Brunswick's International Strategy which asserts that,

The world is changing dramatically. The emergence of the global market economy demands enhanced competency in international business, global market assessment, international finance, cultural awareness, global demographic shifts and intergovernmental relations. Globalization confronts New Brunswick with the paradox of increased opportunities for prosperity while demanding that our economy and our people be globally competitive. $^{138}$

In an anarchic world where there is no central and overarching sovereign that ensures prosperity for all, do regional governments need to take heed of Waltz's teaching that "a state has to rely on its own devices, the relative efficiency of which must be its constant

\footnotetext{
136 Duchacek, 2003: 9-10.

137 See James Rosenau, Along the Domestic-Foreign Frontier: Exploring Governance in a Turbulent World, Cambridge: Cambridge University Press, 1997: 67.

Province of New Brunswick, International Strategy, 2003: 6.
} 
concern?" ${ }^{139}$ Do provinces need to adopt a survival mindset that prompts them to define and pursue their interests in a manner similar to the state's pursuit of self-help measures in an inherently anarchic international environment?

This level of analysis question is highly relevant. Originating from the realist orthodoxy and moving towards the advocacy of complex interdependency, it is recognized that connections between states take place at a multitude of levels, and creates "a situation among a number of countries in which multiple channels of contact connect societies (that is, states do not monopolize these contacts); there is no hierarchy of issues; and military force is not used by governments toward one another." ${ }^{140}$ In 1990, Feldman and Feldman noted that these multiple channels, sometimes known as transgovernmentalism, add a new dimension to foreign policy and international studies.

Students of international relations in general, and most observers of Canadian politics and foreign policy in particular, have not yet appreciated the potential significance of these trends, even though in terms of scope and institutionalization the Canadian provinces provide the most sophisticated example of transgovernmentalism (activity abroad conducted

139 Waltz, 1959: 159. Provinces are not involved in the security imperative of states, which is commonly viewed to be the prime orientation of structural realism theories. Nonetheless, the anarchic environment in which the theory is conceptualized, what Hedley Bull in The Anarchic Society, London: MacMillan, 1977, describes as an anarchic society, exhorts provinces to pursue direct measures to ensure their perpetuation and welfare. Correspondence with Waltz confirmed that he believed the self-help imperative, as it relates to self preservation, can influence the decision-making of provinces and states alike. Thomas Friedman makes a similar observation, noting the importance of decisive decision-making: "A nation's wealth is now principally of its own collective choosing. Location, natural resources and even military might are no longer decisive. Instead, how a nation and its citizens choose to organize and manage the economy, the institutions they put in place and the types of investments they individually and collectively choose to make will determine national prosperity." See Thomas Friedman, The Lexus and the Olive Tree, USA: Anchor Books, 2000.

140 Keohane, Nye, 1989: 249 
by subunits of central government) The Canadian example, however, is not unique, and an understanding of this case $1 \mathrm{~s}$ essential for compiehension of an international system in which central control over foreign policy is fragmenting and definitions of both the physical and metaphysical boundaries of the nation-state are demanding modification. $^{141}$

In the growing study of paradiplomacy, there are several scholars whose work in the state of the art is worth taking special note of

Ivo Duchacek was an early pioneer of the study of paradiplomacy, ${ }^{142}$ arguing in 1988 that regional governments, constituent elements of federations, increasingly looked to the international system for opportunities in areas of their competence and jurisdiction, as well as to take on greater responsibility over issues affectıng their welfare. He maintained that policies developed at the centre frequently did not take proper account of local needs, and that regional governments had come to the realization that their needs could not be satisfied without engaging in direct involvement in the international system. This effectively "perforated" 143 the solid outer border of the state, outside which only central government for so long had been unchallenged.

As another early proponent of paradiplomacy, Brian Hockıng advanced the notion that the discipline should be approached as a crucible in which non-central governments (NCGs) are actors in addition to states, and that as actors unto themselves, should be

$141 \quad$ Feldman, Feldman, 1990: 177

142 See Ivo D. Duchacek, Daniel Latouche, Garth Stevenson, (eds.), Perforated Sovereignties and International Relations Trans-sovereign Contacts of Subnational Governments, New York: Greenwood Press, 1988.

$143 \quad$ Earl Fry, 304 
accorded consideration as they patrol the international "grey zone" where states, CSO and transnational corporations co-exist ${ }^{144}$ (a trend Lecours broadly describes as the "complexification"145 of world politics). This environment Hocking argues, is best described as unpredictable and multilayered, but does not challenge the legitimacy of the nation-state. Rather, in some ways (especially for federal states) it strengthens it by providing a cooperative avenue for the expression and satisfaction of local needs of the population by both the central and regional orders of government. ${ }^{146}$

Adding greatly to the notion that non-central governmental actors within federal states can pursue parochial objectives outside the foreign policy of the state is the work of Panayotis Soldatos ${ }^{147}$ who, also in partnership with Hans Michelmann, ${ }^{148}$ advances the argument that analysts can rationally segment the foreign policy goals of subnational governments and the federal government in increasingly efficient ways depending on the degree to which provincial efforts are integrated with federal ones.

144 See Brian Hocking, "Patrolling the "Frontier: Globalization, Localization and the 'Actorness' of Non-Central Governments," in Aldecoa, Keating, (eds.), Paradiplomacy in Action, 1999: 17.

145 André Lecours, "When Regions Go Abroad: Globalization, Nationalism and Federalism," Globalization, Multilevel Governance and Democracy: Continental, Comparative and Global Perspectives, (Conference paper), Kingston: Queen's University, May 2002.

146 See Brian Hocking, Localizing Foreign Policy: Non-Central Governments and Multilayered Diplomacy, New York: St. Martin's, 1993,

$147 \quad$ See Payayotis Soldatos, "An Explanatory Framework for the Study of Federated States as Foreign-Policy Actors," in Michelmann and Soldatos, (eds.), Federalism and International Relations, 1993: 34-53; and Soldatos, "Cascading Subnational Paradiplomacy in an Interdependent and Transnational World," in Douglas M. Brown, Earl A. Fry, (eds.), States and Province in International Economy, California: Institute of Governmental Studies Press, 1993: 45-64.

148 Hans J. Michelmann, Panayotis Soldatos, (eds.), Federalism and International Relations: The Role of Subnational Units, Oxford: Clarendon Press, 1990. 
As our understanding of regional governments in international relations expanded, works such as Duchacek's 1990 study on the emergence of new actor sets in international relations were supplemented by studies such as Earl Fry's 1998 look at the role of American states and municipal governments in international relations, which provided regional context to the theoretical and conceptual debates. ${ }^{149}$

In Canada, the decentralization of international relations has also been explored in a practical sense in conference environments, with papers being tabled, for example, at the 2004 Québec City Conference on the role of White Papers in Foreign Policy, and the 2006 conference "Polycentric Governance?: Sub-national Governments and Foreign Policy in an Age of Globalization." Rosenau cited in Paquet ${ }^{150}$ describes this new world of multi-dimensional international relations notes in Distant Proximities, "the world is confronted with the challenge of $[\ldots]$ a multi-polar/multidirectional, mixed formal/informal mode of governance that mobilizes the contribution of all actors (from the public, private and social sectors) as producers of governance." Canadian scholarship on provinces' paradiplomatic activities are discussed in greater detail later in this Chapter.

$149 \quad$ Earl H. Fry, "The Expanding Role of State and Local Governments in US Foreign Relations'," Paper Presented at Annual Meeting of Political Science Association: Boston, Massachusetts, 1998.

150 Paquet, "The Many Are Smarter Than The Few," 2006:1. 


\section{Critics and Contrarians}

Despite growth in the ranks of those who support an increased role for regional governments in international relations others question paradiplomacy, and instead appear to support increased centralization. The Saskatchewan Institute of Public Policy (SIPP) advertised an academic/practitioner conference "Constructing Tomorrow's Federalism: New Routes to Effective Governance," noting that "From some quarters come calls for federal government action, even if it means unilateral action in an area of provincial jurisdiction, while from others come demands for a complete disentanglement of provincial public policy from federal influence and oversight." ${ }^{151}$ Certainly this was once the prevailing view of the Government of Canada, which previously asserted that international relations should, for the most part, be a function of the central order of government and preserve of the sovereign state. ${ }^{152}$

This position was once accepted by provincial bureaucrats holus-bolus as demonstrated by Annemarie Jacomy-Millette, who cites examples of support for this kind of federal role coming from Saskatchewan and (surprisingly) Alberta. She observes that the Deputy Minister of Intergovernmental Affairs, Government of Saskatchewan Howard Leeson noted in a speech delivered in Saskatoon, May 29, 1981 that "No one [...] seriously

151 Saskatchewan Institute of Public Policy (SIPP), conference advertisement for "Constructing Tomorrow's Federalism: New Routes to Effective Governance," Saskatchewan, March 24-26, 2004.

152 See Office of the Secretary of State for External Affairs (OSSEA), Federalism and International Relations, Ottawa, 1968; and OSSEA, Federalism and International Conferences on Education, Ottawa, 1968, both of which were used to justify the federal government's displeasure with Québec's proto-diplomatic approach to its engagement of La Francophonie in the late 1960s. 
challenges the primary role of the federal government in developing Canada's foreign policy." 153 Jacomy-Millette also notes that while addressing calls for constitutional change and renewing Canadian federalism, the Government of Alberta published a working paper entitled Harmony in Diversity: A New Federalism for Canada in which it noted in 1978 that "It is generally accepted that the development of foreign policy and the conduct of international relations is the responsibility of the Federal Government." "54 The tone since then, however, has changed substantially, especially as the economic capacity of larger provinces like Alberta has increased spending power and political prerogative.

Some observers still question the legitimacy of provincial governments being active on the international stage, with some even taking up a tone of impatience suggesting provinces should get out of international relations altogether, surrendering areas in which they have clear-cut constitutional jurisdiction. John Ibbitson for example noted in 2005,

There was nothing particularly wrong with U.S. ambassador David Wilkins meeting with the premiers, as he did yesterday, for a getacquainted session. But provincial governments should not be meddling in foreign policy. Quebec Premier Jean Charest fumed that Ottawa signed an adoption agreement with Vietnam, even though Quebec was responsible for its own international adoptions. 'They cannot commit me in my area of jurisdiction,' he complained to reporters. Then again, perhaps international adoptions should not be an area of provincial jurisdiction. Perhaps the provinces should agree to close their foreign-trade offices and cease their demands to be represented at international forums. Perhaps they should let Canada be Canada. ${ }^{155}$

153 Annemarie Jacomy-Millette, "Les activités internationals des provinces canadiennes," in Paul Painchaud, (ed.), De Mackenzie King à Pierre Trudeau : quarante ans de diplomatie canadienne, 1945-1985, Québec, Presses Université Laval, 1989: 83. 154 Ibid.

155 John Ibbitson, "The Premiers Sing in Harmony to Serenade Ottawa," The Globe and Mail, August 12, 2005, p. A13. 
As suggested earlier, the political implications of the media's perspective on provincral internationalism can play a role in limiting how piovinces "go international " After all, what small-town politician would dare invite allegations of wasteful or unnecessary spending on international junkets advanced by a media convinced that only federal governments should step foot outside the gates of the nation-state? While Elazar does not go so far in his study of federal systems as to suggest that Canadian provinces require the appiobation of the central government to pursue their international interests, he subtly suggests that Canadian provinces derive their ability to pursue extra-territonal interests not from the constitution, but on account of the federal government's good graces.

In recent years direct provincial involvement with foreign governments (mainly with regard to trade and economic development [...]) has increased tremendously, largely as a result of a w1llingness on the part of the federal government to allow greater provincial involvement in foreign affairs [. .] the provincial governments are given a fair degree of autonomy in their fore1gn activities. ${ }^{156}$

How foreign policy jurisdiction is viewed by the bureaucracy must not be taken lightly. While not refutıng the provincial nght to participate on the international stage, former Canadian Ambassador to the United Natıons from 2002-2003 Paul Heinbecker argues, "Theories of globalization and the increased roles of private companies, c1vil society and sub-national governments notwithstanding, the basic organizing principle of international relations is still the state, unitary or federal. Diminished in some fields though states may

156 Daniel J. Elazar, (ed.), Federal Systems of the World: A Handbook of Federal, Confederal and Autonomy Arrangements, Jerusalem Institute for Federal Studies, United Kingdom, Longman Group, 1991: 63. 
be, but the state nonetheless " 157 This deference to the federal juisdiction in international 1elations by provinces (other than Quebec) can be, therefore, construed as commonplace amongst Canadian piovinces in spite of their own individual agendas, goals and objectives

\section{Trends in Canada's Constitutional History}

Prologue-Early Concerns of the Founding Fathers

Comprehending Canada's constitution, its ongins and issues that influenced its composition provides insight into how Canadian federalism relates to the provinces' goal of participating in international affairs Library of Pailiament researcher Wolfgang Koerner touched on the general helpfulness of revisiting onginal "intent" in his analysis of Canada's constitutional crisis in the late 1980s, and argues such retiospection is helpful when political systems with intergovernmental and constitutional implications are 1nvolved ${ }^{158}$ Canada's foundıng fathers envisaged federal model that would serve a transcontinental nation while retaining a constitutional monarchy under the British Crown Inherent to this was a strong cential government working in partnership with regional governments Prior to Confederation in 1867, John A MacDonald took careful note of the United States' difficulties 1esulting from the infusion of regional orders of

$157 \quad$ Hembecker, 20063

158 "[ ] in order fully to understand the present state of union, we need to come to terms with the intentions of its founde1s It is during times of crisis and rapid change that we often return to an examination of original intentions, for it is the original "intent" that goes a long way in determınıng the unfolding of the political process" Wolfgang Koerner, "The Foundations of Canadian Federalısm," Library of Parliament, Parliamentary Research Bianch, Decembe1 19882 
government with (in his thinking) excessive junsdictional ieach, which in turn led to inter-jurisdictional wrangling In 1861 he argued that Americans had erred in making "[.. ] each state a distınct sovereignty, and giving to each a distınct sovereign power, except in those instances where they were specially reserved by the Constitution and conferred upon the general government." ${ }^{\text {159 }}$ Robert Vipond notes that,

\begin{abstract}
"The conventional wisdom among Canadian constitutional historians is that the American constitution was influential in Canada principally in that it served as a negative model If the Canadian Fathers of Confederation held any truth to be self-evident, it was that the Americans had made a fundamental constitutional mistake in $1787[\ldots]^{160}$
\end{abstract}

Instead of repeatıng the same mistakes made by Canada's nerghbour to the south, Macdonald believed that, "We should have a powerful Central Government- a powerful Central Legislature, and a powerful decentralized system of minor legislatures for local purposes."161 In 1864 at the Québec Conference MacDonald stated to a large crowd including Nova Scotia Premier Charles Tupper that "it is for us to take advantage by experience, and endeavour to see if we cannot arrve by careful study at such as plan as will avord the mistakes of our neighbours." 162 Ramsay Cook notes that any thought that the federal state to be born would have equal power-sharng between the regions and the center was misplaced, and that "the constitution-makers of 1867 took as their pattern not 159 Koerner, 1988: 4.

160 Robert C. Vipond, "1787 and 1867: The Federal Principle and Canadian Confederation Reconsidered," Canadian Journal of Political Science, No. 1, March 1989: 3. Vipond presents a comprehensive overview of these issues in Chapter 2 of his volume, Liberty and Community: Canadian Federalısm and the Fallure of the Constitution, SUNY Press, 1991: 15-46.

161 Koerner, 1988: 4.

162 Donald Grant Creighton, P.B Warte, John A. Macdonald. The Young Politician, the Old Chieftain, Toronto: University of Toronto Press, 1998: 369. 
the Ameican federal system, but rather the Britısh Empise in which Ottawa replaced London and the provinces assumed the role of colonies "163

As Confederation drew closer, MacDonald remained cautious about a political system domınated by a majonty of Members of Parliament from Upper Canada To ensure each provincial government no mattei how large or small was equal, could vorce its interests 1n the national Parliament and be reflected in federal legislation, the Senate of Canada was created "MacDonald cleatly realized that he would have to assuage Upper Canada's desıe for representation by population, provide for Québec's demands for cultural autonomy, and permit the Maritime provinces to retain a certain level of political identity." ${ }^{64}$ One last concession MacDonald would make, albeit reluctantly, was on the nature of the federal relationship and equitable division of powers and legitimacy between the central and reg1onal governments.

Vipond's hypothesis is instructive here. He advances the argument that MacDonald's goal of a highly centralized, if not functionally unitary, federal government did not prevall on account of the agitation of advocates of classical federalism. These individuals, he argues, believed that problems expenenced by the American federal system could be avoided through the establishment of a strong Constitution that clearly laid out the roles and responsibilities of each order of government. ${ }^{165}$

163 Ramsay Cook, Provincial Autonomy, Minority Rights and the Compact Theory, 1867-1921, Ottawa. Queen's Prunter, 1969: 8

164 On the last point, through enhanced representation in the Senatorial Upper House. Koerner, 1988: 11.

$165 \quad$ Vipond, 1989: 5. 
Despite MacDonald's acquescence on the further periphesalization of the provinces, however, he did not deviate from his fundamental belief that there should be little if any role for the provinces to participate in international relations, which would effectively diminish the primacy of the central government In his view the centre must retain pimacy in the pursuit of the Dominion's extraterntonal interests An ardent supporter of the British monarchy and Crown, he believed that federal jurisdiction over external affarrs was essentral, and the Governor-General as the Queen's representatıve in Canada should be the official and only channel of communication between Ottawa and London, through which the Dominion of Canada's external interests were to be relayed. Soward in Lower, Scott et al noted that in 1879 Canada was given the warning that, "The Dominion cannot negotiate independently with foreıgn powers and at the same tıme reap the benefit which she desires in negotiations from being a part of the Empire."166

It was this same conceptual model with which MacDonald sought to define Canada. Deference to the Crown in international matters came with a two-fold advantage. By surrendering foreign polıcy autonomy to the Empire, Canada would benefit from the Empire's growth and contınued prospenty. Furthermore, association with the Empire would place Canada under the protective global umbrella of the United Kingdom, which included an array of military, economic and political measures. Drawing from MacDonald's fear that excessive empowerment of provinces could cloud Canada's internatıonal interests, direct provincial activity in international relations was highly discouraged by the federal government, although the punitive measures for non166 F.H. Soward, "External Affarrs and Canadian Federalısm," in A.R.M. Lower; F.R. Scott $e t$ al, Evolving Canadian Federalısm, London Cambridge University Press, 1958: 128 
compliance were unclear. That sard, such activities were rare in early Canada MacDonald's support of employing disallowance to ensure subordination of the provincial legislatuies to Canada's fore1gn policy lead was revealed when he noted,

As this is to be one united province, with the local governments and legislators suboidinate to the General Government and Legislature . [the] General Government assumes the local governments precisely the same position as the Imperial Government holds with respect to each of the colonies now... ${ }^{167}$

In short, the provinces were under the thumb of the federal government, which itself was undei the Imperial government for all external affairs. This position would set the stage for the work of K.C. Wheare, one of the early writers on federalism models, who in making that argument that the foreign relations of a federation would be assumed to fall under the purview of the central government, famously wrote "Federalism and a spinted foreign policy go 11 ll together." 168 Wheare thus captures the tension that exists between: a) the assumption that central governments have near sole jurisdiction over foreign policy and are free to do as they will on the international stage; and b) complications that arise within federal states when the central government, in its exuberance to enter into international agreements, commits itself into policy areas designated by their own constitution as an area of regional government jurisdiction.

167 Speech of Sir John A. MacDonald in Parliamentary Debates on the Subject of the Confederation of the British North American Provinces, (1865), p. 42, cited in Beck, 1971. 149

168 K.C. Wheare, Federal Government, New York: Oxford University Press, 1964: 186. 


\section{Confederation and After}

As Canada moved towards Confederation in 1867, the general contours of the British North America Act started to become visible. For better or worse, however, the implications for federal-provincial relations as related to international activities remained clouded. Federal primacy in Canada's international relations originated from the strong relationship between the Dominion of Canada and Britain and Canadian foreign policy prior to the British North America (BNA) Act in 1867, when both fell under the purview of Whitehall. Few provisions for the Parliament of Canada to play an active role in Canada's external relations were included in the BNA Act, the notable exception being Article 132 which stated,

The Parliament and Government of Canada shall have all Powers necessary or proper for performing the Obligations of Canada or of any Province thereof, as Part of the British Empire, towards Foreign Countries, arising under Treaties between the Empire and such Foreign Countries. ${ }^{169}$

The BNA Act relaxed British control over Canadian foreign policy, but also accorded de jure power to implement agreements signed by the British Crown and foreign governments to Canadian federal authorities. No provision was made to include provinces, an issue that would resurface as Canada moved towards greater administrative autonomy. ${ }^{170}$ Thinking back to Koerner's earlier statement, framers of the BNA Act would have done well to consider the extraterritorial interests of the provinces during this time of "rapid change," as well as the classical federalists' opinion (mentioned earlier by

170 See British North America Act, sections 91, 92. 
Vipond) that a clearly laid out Constitution could play a helpful role in dispelling Constitutional obfuscation on the division and assignment of jurisdiction

During this time, authority and jurisdiction to enter international treaties and agreements devolved from Whitehall to the Canadian Parliament. Provinces expressed alarm that the federal government would parlay its newfound autonomy into an opportunity to intrude into areas of provincial jurisdiction. ${ }^{171}$ Nossal points out that ambiguity in the BNA Act regarding allocation of powers between the federal and provincial governments was understandable, however, given that the Act was not designed to provide a constitutional backbone for an independent state. "Perhaps somewhat short-sightedly, those who framed Canada's original constitution did not concerve that the new domınıon might eventually enjoy the same autonomy in foreign policy as it was receiving in domestic affarrs. Certainly, in 1867, (as a member of the Empire) could have no independent international personality." 172

As questions over federal-provincial relations intensified in the 1930s, the Judicial Committee of the Privy Council (JCPC) in London assisted in the interpretation of sections 91 and 92 of the BNA Act that dealt with peace, order and good governance

171 With respect to fears that the central government would on the domestic front engage in jurisdictional creep, Vipond points out that various provisions in the BNA Act effectively portended the marginalization of the provinces. "The most perceptive of these critics were Antome-Aime and Jean Baptiste Eric Dorion, Rouge representatives from Lower Canada, who insisted that Confederation would become for all intents and purposes a unitary government because the provinces would be both too weak and too vulnerable to defend themselves against the imperious and meddlesome designs of the federal government." 1989: 9.

172 Kim Richard Nossal, The Politics of Canadian Foreign Policy, (2 ${ }^{\text {nd }}$ edition), Canada: Prentıce-Hall Canada Inc., 1989· 258. 
(POGG), and how the federal government's primacy in those areas as well as foreign policy related to the jurisdictional responsibilities of the provinces. In so doing, the JCPC rendered several decisions that had a profound impact on the highly Ottawa-centric federal structure once envisaged by the Fathers of Confederation. ${ }^{173}$ "From the highly centralist document of 1867 , the British North America Act was transformed, by the incremental process of judicial review, into a more truly federal constitution, which vests extensive legislative authority in the hands of the provinces."174

This evolution meant that from the late 1800 s to 1930 "except for the First World War, provincial powers increased as a result of strong political leadership in certain provinces and judicial decisions favouring the provinces in constitutional disputes with the federal government." 175 Judicial decisions regarding the conduct of public policy by provinces and the centrality of the federal government in areas of foreign treaties and international agreements include three significant cases: the Aeronautics Case of 1932, the Radio Case of 1932 and the Labour Conventions Case of 1937.

These cases established the extent to which the federal government could act unilaterally in foreign affairs. The Aeronautics Case of 1932 established the federal government's ability to pass laws as part of the British Empire conforming to international treaties that 173 For additional information, Alan Cairns discusses pros and cons with respect to the JCPC's interpretations of the BNA Act in "The Judicial Committee and its Critics," Canadian Journal of Political Science, September 1971. Also see H.M. Clokie, "Judicial Review, Federalism, and the Canadian Constitution," Canadian Journal of Economics and Political Science, Vol. 8, No. 4, November 1942.

174 Richard Van Loon; Michael S. Whittington, The Canadian Political System: Environment, Structure and Process, (4 ${ }^{\text {th }}$ edition), Canada: McGraw-Hill Ryerson Ltd., 1987: 249.

175 Kernaghan, Siegel, 1991: 419 
were neither in the federal jurisdiction, nos as a function of the federal government's right to mantain "Peace, Order, and Good Government," but sather as a function of the Dominion's jurisdiction thiough Section 132 of the BNA Act which gave it authority to pass laws concerning Canada's interaction with other states The Radio Case was also heard by the JCPC in 1932, and established that since Canada passed this legislation as an 1ndependent actor and not as part of the B11t1sh Emp11e, Section 132 no longer applied That said, the case also established that the federal government could lay claim to jurisdiction, in that while radio conventions were not mentioned in the constitution, they did fall withın the general provisions outlined in Section 91 of the Constitution outlining the obligation to ensure peace, order and good government ${ }^{176}$ In contrast to the first two cases, the Labour Conventıons decision was particularly damaging for advocates of Ottawa's right to enter into foreign agreements of provincial responsibility. In this case, Lord Atkin delivered a stingıng repudiatıon of Ottawa's efforts to apply (vis-à-v1s signature of an international agreement) universal federally-determined minimum and maximum wage controls across Canada, despite having neither the consent of the provinces nor the jurisdiction to effect the change. He stated, "The Dominion cannot, merely by making promises to foreign countries, clothe itself with legislative authority inconsistent with the Constitution which gave it birth," and famously noted,

It must not be thought that the result of this decision is that Canada is incompetent to legislate in performance of treaty obligations. In totality of legislative powers, Dominion and Provincial together, she is fully equipped. But the legislative powers remain distributed, and if in the exercise of her new functions derived from her new international status Canada incurs obligations they must, so far as legislation be concerned,

176 See Gregory S. Mahler, New Dimensions of Canadian Federalism: Canada in a Comparative Perspective, Associated University Presses, Ontario, 198744. 
when they deal with Provincial classes of subjects, be dealt with by the totality of powers, in other words by co-operation between the Dominion and the P1ovinces. While the ship of state now sa1ls on lat ger ventures and into fore1gn waters she still retans the wate1-tight compartments which are an essential part of her original structure ${ }^{177}$

The significance of these three cases lies in their collective relevance to the debate over whether the federal government could conclude treaties with foreign jurisdictions in areas of provincial jurisdiction, and whether it could use provisions of an agieed-upon treaty to coerce provinces into action in areas in theiı own jurısdiction Weiler finds the Canadian experience in this regard particular interesting, and in his consideration of federal states and international treaties, notes that "As Canada acquired full external powers the question arose as to those non-Imperial treaties which covered matters which were outside the internal jurisdiction of the federation though inside the treaty-making power." ${ }^{178}$ Ultimately, as Baier rightly points out, ${ }^{179}$ the JCPC roundly rejected Ottawa's preference to use POGG as a mechanism with which to challenge the boundaries of the provinces' constitutional powers.

177 Labour Conventions Case, 1937, App. Cas. at 353-54, cited in Jeffrey L. Friesen, "The Distribution of Treaty-Implementing Powers in Constitutional Federations: Thoughts on the American and Canadian Models," Columbia Law Review, Vol. 94, No. 4, May 1994: 1431.

178 Joseph Weiler, The Constitution of Europe "Do the New Clothes Have an Emperor?" and Other Essays on European Integration, Cambridge University Press, 1999: 139.

179 "Historically, judicial review was often blamed for the expansion of provincial power, if not for the permissive interpretation of provincial powers by the Lords of the Judicial Committee of the Privy Council (JCPC), the argument went, the strong central government envisioned by the Fathers of Confederation would have been realized." Gerald Ba1er, The Courts, the Division of Powers, and Dispute Resolution, in Bakv1s and Skogstad, (eds.), 2008: 24-5. 
Such decisions helped bieak the constitutional "1mpasse" of the 1930s and suggested that 1athes than heading to legal pioceedings and bitter federal-piovincial confiontations, a 1enewed commitment to collaborative federalism, the intergovernmental affaris process and demonstiation of inter-juisdictional flexibility might offer a non-constitutionallyaltering way to resolve disputes In reviewing post-wat Canadian federalism, Smıley notes, "a 1ecognition of this actual or potential flexibility in much of the recent witing on the Canadian federal system, a 1ecognition that significant developments in provincialfedeial relations can come about without either a change in the pattern of judicial interpretation of the BNA Act or of amendment to that Act "180 There 1s, however, little resolution to the nature of the conflict itself Nossal observes,

Although the patration process of the early 1980s provided Canada's 11 governments with an opportunity to modernize the constitution by including a clearer reference to foreign affairs, the attentions of the first ministers and the11 delegations were fixed on far more pressing problems As a result, the Constitution Act, 1982, leaves the question of the competence of the provinces in the area of foreign affars as constitutionally unclear as the BNA Act had in 1867 In the absence of any constitutional prohibition against international activity, Canada's provincial governments have sought to project and protect their interests beyond their- and Canada's- borders ${ }^{181}$

Over the past 70 years, Canadian federalism has not been able to work out the issue of inter-juisdictional friction over international relations While (anecdotally speaking) Canadian federal government officials are quick to remind their provincial government peets that the Constitution gives Ottawa the power to enter international agreements, piovincial representatives aie quick to remind that this does not justify federal

$\begin{array}{lll}180 & \text { Smiley, } 1962 & 59 \\ 181 & \text { Nossal, } 1989 & 258-9\end{array}$


encroachment into areas of provincial jurisdiction Canada's ratıfication of the Kyoto Piotocol ${ }^{182}$ piovides an illustration (notwithstanding its normative objectives) of the federal government's unflinching willingness to trample constitutionally-established jurisdictional boundarıes So too was former Pıme Minıster Paul Martın's threat to use orl sanctions to force a settlement of Canada's softwood lumber dispute with the United States an example of Ottawa's willingness to leverage the energy sector (a provincial area of ju11sdiction) as a trade dispute mechanism ${ }^{183}$

In both instances acrimonious federal-piovincial exchanges ensued, with provincial rhetoric 1egardıng the excesses of a federal government intıudıng into areas then ateas of competence The Joint Meetıng of Ene1gy and Envi1onment Minısters in Halifax, Nova

182 Issues such as energy industries, power generation and environmental impact standards relating to greenhouse gas emission relate directly to line department functions provided by the Department of Environment, which as required, works in collaboration with the federal Department of Environment where federal interests are involved, such as coastal waterways, endangered species and habitats are involved Harmonization of policy development and enforcement of regulations have significant intergovernmental relations implications For an excellent review of 1ssues of relevance in the Canadian context, see Patrick Fafard, Kathryn Harrıson, Managing the Envilonmental Union Intergovernmental Relations and Environmental Policy in Canada, School of Policy Studies, Queen's University Kingston, 2000, and Grace Skogstad, "Intergovernmental Relations and the Politics of Envilonmental Protection in Canada," in Kenneth M Holland, Frederıck Lee Morton, Buan Gallıgan, (eds ), Federalısm and the Environment Environmental Policymaking in Australia, Canada, and the United States, Greenwood Publishing, 1996 103-134

183 Concerns regarding the federal government's management of the Canada-US relationship were 1 aised at the $44^{\text {th }}$ Annual Premiers Conference in Charlottetown on July 9-11, 2003 following ant-American remarks made by members of the Chretien government caucus Provincial governments felt that poor diplomatic relations were the product of national trade disputes and Canada's position on American military actions in Afghanıstan and Iraq Fearıng poor bilateral relations would affect their welfare, "Premiers called for a more open and collaborative partnership with the federal government in oxder to ensuie provincial/territorial interests are effectively sepresented in Canada-US ielations " Atlantıc Premieıs Conference, 2003 
Scotıa, October 28, 2002, for example, produced a Provincial and Territorial Statement on Climate Change Policy statıng,

The federal framework on climate change, announced on Octobe1 28, does not as yet represent an adequate Canadian approach to reducing gieenhouse gases in Canada Provinces and Territones desire a national plan [.. ] The plan must respect Provincial and Teiritorial jurisdiction. ${ }^{184}$

Despite such intergovernmental tensions Brown observes that, "Canada seems to lead the world in direct provincial intergovernmental activities abroad, particularly in those areas that are not just cross-border 1ssues." 185 To optimize the shared responsibility, however, Courchene offers caution to provinces that they too must consider their international activities as takıng place within a federal context. In an Ontario government publication he writes,

[...] the provinces must have the flexibility to design and deliver their own vision and version of the socio-economic envelope $[\ldots]$ the ongoing blossoming of provincial experimentation across a range of fronts is absolutely critical to recreating an efficient and viable social Canada. The policy challenge here is to ensure that this experimentation takes place within the framework of 'national' (federal, federal-provincial or interprovincial norms or principles. ${ }^{186}$

Because of Canada's indeterminate constitutional division of powers between the central government and the provinces and territories, a systemic lack of clarity persists on where the international responsibilities of each order of government begin and ends.

184 Joint Meeting of Energy and Environment Minısters (JMEEM), "Provincial and Territorial Statement on Climate Change Policy," (press release) Halifax, October 28, 2002

Brown, 2002: 12 .

186 Courchene, 1996: 9-10, cited in Richards in Lazar, 1998 89-90. 
Overlapping interests are the norm Feldman and Feldman note that the very act of provinces projecting themselves internationally speaks to their percerved need to pursue their interests on the world stage Of the provincial governments they note

Their fum commitments to defend provincial interests beyond Canadian borders challenge conventional concepts of sovereignty and the federal view of a national monopoly in the field of foreign policy Theis international activities question the exclusive claim of the Government of Canada to make foreign policy, especially in matters other than diplomacy and security 187

This inteigovernmental tension is important to understand, and has deep implications fo1 Canada's system of federalism and Canada's foreign policy Clearly, in this age of globalization, there are new pressures on the federal state with respect to intergovernmental jurisdiction over policy areas with international implications Who makes the call on who has authoity over one policy or another, especially in areas of concurrent jurisdiction, and how is conflict managed with the fedeial and provincial governments chase the same international opportunities? The following section examines Canada's federal system in search of the answers to some of these questions, and seeks to explain how Canada's federal system has been affected by increased provincial activities in international relations

187 Feldman, Feldman in Michelmann, Soldatos, 19901767 


\section{Canada's Federal System}

This next section looks at the evolution of Canadian federalısm and how it affects the standing and stiategies of different provinces, including New Biunswick.

\section{Canadian Federalısm}

The study of Canada's system of federalısm cannot easily be distilled from consideration of Canada's constitutional evolution, dynamics related to the rise of Canadian provincial paradiplomacy and the trend of "province-building" They are two sides of the same coin Federalism involves division of legislative powers between central and regional governments. In Canada, this division does not imply ordination of one o1der of government over another. Both "levels" (a misnomer itself since "levels" incorrectly implies vertical hierarchy) are equal in status and rights as assigned by the Constitution. Accordingly, each government retains autonomy in scheduled areas of jurısdiction, as well as fiduciary responsibilities in areas of shared jurisdiction. Sections 91 and 92 of the Britısh North America (BNA) Act outline the legislative powers of the federal and provincial governments in Canada Where concurrent or contradictory legislation occurred, Acts of Parliament were deemed to be prevalent.

Federalısm seeks to explain the relationship between central and constituent orders of government in politıcal systems in which sovereıgnty is divided Bélanger offers a simple definition of federalism as "the distribution of sovereignty between two levels of 
government in such a way that neither level is entire subordinated to the other." 188 David Cameron provides a deeper understanding in the Canadian context, noting that Canada has a "divided rather than shared model of federalism,", 89 and despite having had an originally-paternalistic oversight role assigned to the centre over the provinces, has since become highly decentralized due factors such as: judicial decisions vindicating provinces' calls for greater powers; the inability of the center to meet the needs of the regions; the growing importance of areas of provincial jurisdiction; and Québec's campaign of agitating for increased provincial autonomy in (and outside) areas of constitutional jurisdiction. Despite these pressures to force change upon the Canadian Constitution, contemporary efforts to modernize it have failed. Simeon notes,

The institutions of Canadian governance, with their built-in incentives and constraints, are remarkably resistant to change. For example, despite the massive changes that have occurred in the Canadian society and economyglobalization, multiculturalism, the mobilization of Aboriginal peoples, and the rise of non-territorially-defined social movements the dynamics of executive federalism of 'federal diplomacy' today look remarkably like those that existed in the $1960 \mathrm{~s} .{ }^{190}$

The area of greatest concern with respect to the Constitution's current state of stasis is with respect to the division of international responsibilities, areas of shared interest and points of conflict that stymie New Brunswick from reaching its international objectives. In instances where legislation or government action is inconsistent with the constitutional 188 Bélanger, 2000: 1.

189 David R. Cameron, "Canada," in Griffiths, Nerenburg, (eds.), Handbook of Federal Countries, 2002, 2003: 180.

$190 \quad$ Simeon and Nugent in Bakvis and Skogstad (eds.), 2006: 90, citing Richard Simeon, 'Postscript,' in Federal-Provincial Diplonacy: The Making of Recent Policy in Canada, Re-issued with a new postscript, Toronto: University of Toronto Press, 2006: 314-32. 
division of powers, determination of juisdiction is well-informed by the works of Peter Hogg, Gerald Ba1e1, Harvey Lazar, and Peter Russell among others. ${ }^{191}$ The concept of "intermesticity" as discussed by Burton ${ }^{192}$ in international affairs is useful here as well, in describing the blurring of boundaties between considesation of local and international matters

Where jurisdictions intersect, it is important to maximize cooperation, mitigate conflict and determine how opportunities for mutual gain can be realized to avo1d confusion and ineffective policy delivery. Here the concepts of "cooperative" federalism, ${ }^{193}$ "competitıve" federalısm and inter-jurısdictıonal policy coordination are introduced to segue into discussion of province-bullding concepts, using case examples from current 1ssues in Canadian and New Brunswick international affarrs policies. If it is important to Canadian federalısm that each order of government possesses an autonomous sphere of jurisdiction in which the other cannot impinge, it is also important that a balance be maintained between the two orders of government where either the centre is subordinate to the provinces (confederalism), or the provinces are subordinate to the centre (unitary).

191 See for example: Peter Hogg, Constitutional Law of Canada, (4 ${ }^{\text {th }}$ edition), Toronto: Carswell, 1996; Gerald Baier, Courts and Federalısm: Judicial Doctrine in the United States, Australia and Canada, Vancouver: UBC, 2006; Harvey Lazar, "Managing Interdependencies in the Canadian Federation: Lessons from the Social Union Framework Agreement," Constructive and Cooperative Federalısm, Kingston/Montreal: IIGR/IRPP 2003, and Peter Russell, "The Supreme Court and Federal Provincial Relations: The Political Use of Legal Resources," Canadian Public Policy, 11, 2, 1985.

192 "Intermesticity" as posited by Burton suggests that domestic activities can have international effects and international conflict invariably has "a spillover effect of domestic system failings and domestic politics." John Burton, "World Society and Human Needs," in International Relations: A Handbook of Current Theory, Margot Light; A.J.R Groom (eds), London: Pinter, 1985: 52.

$193^{3}$ See Donald V. Smiley, "The Rowell-Siro1s Report, Provincial Autonomy, and Post-War Canadian Federalısm," Canadian Joumal of Economics and Polutical Scrence, 28, February, 1962. 
While Bakvis and Skogstad observe that intergovernmental equilibirum and 1egional iepresentation is sought through the institutions of Pallament, ${ }^{194}$ New Brunswick (unlike other federal systems like Geımany) does not have effective and direct representation in the federal governmental system Therefore, "with limited oppoitunity for formal iepiesentation of provincial interests in federal policy-making institutions, provincial governments acquire gieate1 authonty to speak on behalf of the people withın their borders "195 Unlike some bicameial federd systems in which members of the federal Upper House sit in the executive or Cabınet as a norm rather than exception, Canadian Senators aie not especially helpful in this respect given their limited executive powers

Within the Canadian federation inter-piovincial asymmetry ( $1 \mathrm{e}$ provinces of differing sizes), a lack of coordinated internal policies, practıces regarding international affarrs within provinces and the increasing importance of global engagement are other factors which should be considered This point is discussed by Douglas Brown ${ }^{196}$ and Graham White, ${ }^{197}$ who agree that size and capacity are considerations with influencing regional government's international activities Donald Savo1e reinforces this point in his interpretation of the economic development challenges faced by New Brunswick during Frank McKenna's premiership, durıng which tıme he argues that economic development intensified despite a lack of federal regional infiastructure development assistance in 194 Herman Bakvis, Grace Skogstad, (eds), Canadıan Fedeıalısm Performance, Effectiveness, and Legitimacy, $2^{\text {nd }}$ Ed, Canada Oxford University Press, 20085

$195 \quad$ Bakvis and Skogstad, Canadian Federalısm, 20085

196 Douglas M Brown, "A Baseline Study of International Relatıons and the Federal System," (revised diaft), Kingston Institute of Intergovernmental Affai1s, Queen's University, December 1999

197 White, Giaham, "Big is Different Fiom Little On Taking Size Seriously in the Analysis of Canadian Governmental Institutions," Canadian Public Adminlstration, 33(4), 1990 
New Brunswick despite similar federal investments in other 1egions of Canada The end result he argues, as have others like Hugh Thorbuin, create and sustan high degrees of asymmetry between piovincial and federal governments ${ }^{198}$

The link between federalism and provinces' international policies can be seen in different ways Some emphasize legalistic means that "entailed investigation of the ways in which those formalized relations contained in the constitution are interpreted and applied,",199 and others rely on the conduct of bureaucratic politics to explain advancing interests, which "refers to the bargaining ove1 intergovernmental matters among ministers and officials in departments and agencies within each order of government," each of which is "a loose coalition of organizations and the negotiating positions of the governments as outcomes of an internal negotıatıng process."200

Understanding the theory and practice of Canadian federalısm has important implications for the study of New Brunswick and its international affairs, in that constitutional division of powers and the manner by which the federated state is administered have implications on the way that policy interests are pursued, intergovernmental cooperation is sought for strategic purposes, and potent1al conflict is managed. This section w1ll discuss three bioad directions in which Canadian federalism has evolved (legal, rational/functional and societal), keeping in mind the goal of explaining New

198 See Donald Savore, Pulling Against Gravity: Economic Development in New Brunswick Durıng the McKenna Years, Institute for Research on Public Policy, Winter, 2001, and Hugh G Thorburn, Politics in New Brunswick, Toronto. University of Toronto Press, 1961.

199 Charles D Tarlton, "Symmetry and Asymmetry as Elements of Federalism: A Theoretical Speculation," Journal of Politics, Vol 27, 1965: 862

$200 \quad$ Kernaghan, Siegel, 1991·430-1 
Biunswick's puisuit of 1ts international interests within this broader context In this sense, New Brunswich's international policies can be seen as a diect outgiowth, function and consequence of the Province's relationship with the federal government, and therefore 1equises some attention

In the early $1960 \mathrm{~s} \mathrm{KC}$ Wheare argued that power between cential and regional governments was divided so each order had a specific obligation within a political system, and for the system to work optimally he believed each must voluntarly respect the other's sphere of assigned responsibilities "It is not enough that the federal principle should be embodied predominantly in the written constitution of a country" 201 he wrote, and both o1 ders of government could cooperate if they respected each other's jurisdiction Wheare's critics, however, atgued his chatacteilzation was too mechanical and underestımated the value of intergovernmental affarrs and the informal networking of government Rational structure of government alone was insufficient, the interaction of bureaucrats, elected officials and other stakeholders played a critical role Smooth governance consisted of more than logical and flowing organızational charts Stevenson notes overly stylized organization divisions of juisdiction "are so restrictive that their applicability to even those consideied the most federal of states can be questioned "202

William Rikeı advanced a functional view of federalısm where the relationship of political elites and bureaucratic officials would be leveraged to advocate and defend the

201 K C Wheare, Federal Government, $\left(4^{\text {th }}\right.$ edition), Oxford Oxford University Press, 196333

202 Garth Stevenson, Unfulfilled Union Canadian Federalism and National Unity," Toronto MacMillan Press, 19897 
interests of the11 respective governments. ${ }^{203}$ In a way, he echoed the views of American statesman Thomas Jefferson who thought federalısm was a political and democratic concept as much as a legal and constitutional mechanism, and that federalısm allowed political authorty to be accorded to local centres throughout the nation-state as a way to avoid tyrannical rule

It is not by the consolidation or concentration of powers, but by their distribution, that good government is effected. Were not this country [the United States] already divided into States, that division must be made, that each might do for itself what concerns itself diectly, and what it can so much better do than a distant authority. ${ }^{204}$

The divergence between these two visions of federalism lay in the distinction between formal-legalistic model and a dynamic political model. Where the former articulated the interaction between constitutionally-defined orders of government interacting with organizational-chart style formality, the other was more organic in character, and emphasized the importance of interactivity between government officials, autonomy of regional governments and democracy.

A third view of federalısm was advanced by William Livingstone, who viewed federalısm less as a legal-constitutional and political system of government, and more as an organizing principle based on societal forces. Noting "Almost every treatment of federal government and its problems has begun with the assumption that the problem

203 W.H. Riker, Federalısm: Orıgn; Operation, Signıficance, Boston: Little, Brown, 1964-11.

204 Tarlton, 1965. 864. 
here concerned is one of legal formalism and formal junsprudence" 205 he rejected schools of thought viewing federalism as a mechanism through which institutional and constitutional structures of the state were realized. He believed that,

\begin{abstract}
Above and beyond this legalism the1e is an aspect of federalısm that has been largely ignored The essential nature of federalism is to be sought for, not in the shadings of legal and constitutional terminology, but in the forces-economic, social, political, cultural — that have made the outward forms of federalism necessary. ${ }^{206}$
\end{abstract}

During these years in which provinces were beginning to look outside the federation for opportunities, Livingstone maintained federalısm was an 1deal mechanısm through which to protect social interests. "The essence of federalism lies not in the constitutional structure but in the society itself. Federal government is a device by which the federal qualities of the society are articulated and protected." 207 In his view, the greater the diversification of decision-making within the function of government, the better the interests of people were represented and defended.

How do both jurısdictions coordinate their activities in areas of shared interest? How do political and bureaucratic structures interrelate? Smiley provides some insight into such questions, in noting that both orders are obliged to work with one another, the significance of which is captured in the following paragraph, which notes that each order of government has constitutionally-assigned powers in which the other should not

205 Livingstone, William S., "A Note on the Nature of Federalısm," Political Science Quarterly, Vol. 67, No. 1, 1952: 81.

206 Livingstone, 1952. 83-4.

207 Livingstone, 1952: 84. 
interfere o1 subjugate Where these interests may inteisect, governments that are unwilling or unable to work with one another do a disservice to their citizens-

(1) There is a constitution which distributes the powe1s of government between central and regional governments and which provides some protection for the people and/or the governments of these regional units in the structure and operation of the central government; (2) The elements of the constitution related to the iespective powers of the centre and the regions are not subject to change by the action of the central or regional governments alone; and (3) Individual citizens and private groups are subject to the laws and authoritative exercises of power by both the central and regional governments. ${ }^{208}$

As Canada evolved past early governance models that accorded de facto subordination of the regional governments to the central government in matters of foreign affairs, ${ }^{209}$ Canada's movement from the 1930s to the present was influenced by the following phases.

\section{Classical Federalism}

Post-war Canadian federalısm represented a break from the relatively fractious relationship that was the norm in the years leading up to that time. Defining characteristics of this period include a diminished use of the powers of reservation and disallowance and increased empowerment of the provinces. During this time Ottawa liberally used constitutionally-established powers of provincial legislation disallowance

208 Donald V. Smiley, The Federal Condition in Canada, Toronto: McGraw-Hill Ryerson, $1987 \cdot 2$

209 A tendency referred to by Rand Dyck as "quası-federalısm" Canadian Politics: Critical Approaches, $3^{\text {rd }}$ ed., Ontario Nelson Thomson Learning, 2000: 55-57, 90; and Hogg, Constitutional Law of Canada, $4^{\text {th }}$ ed., 1997: 120 
by modern standards, but there was a markedly greater commitment to intergovernmental respect and equality. During this time cooperation and consultation rather than judicial procedures were used to resolve differences, but each order of government did so within the formal confines of their jurisdictional parameters. ${ }^{210}$ Whereas it is difficult to pinpoint exactly when "cooperatıve federalısm" emerged, the practıce of classical federalism and reinforcement of equality between the federal and regional governments from the early $20^{\text {th }}$ century to the immediate post-war era set the stage for unprecedented levels of federal-provincial cooperation through institutional, political and bureaucratic channels.

Cooperative, Executive and Sometimes Competitive Federalism

Although during the Second World War the federal government again exhibited (nowrestrained) tendencies towards centralization of powers and the usurpation of provincial prerogative, the evolution of classical federalısm brought about greater interjurısdictional cooperation and a softening of the rigidity of intergovernmental relations. So too did the new imperatives of the rise of the welfare state and creation of national healthcare system, which hinged on Ottawa and the provinces dealing with one another cooperatively.

210 Durıng the First and Second World Wars, as well as durıng varıous points durıng the Depression, the federal government assumed a broader array of powers, many of which clearly encompassed areas of provincial jurisdiction. 
This resulted in dramatic changes to Canadian federalism, prompting Smiley to famously note that classical federalism "has no ielevance today."211 J R. Mallory suggested in 1965 that classical federalism had been displaced by a new form of federalism in which "there is close contact and discussion between ministers and civil servants of both levels of government so that even changes in legislation are the result of joint decisions."212 This phase of federalısm was dubbed variously as cooperative, administrative or executive tederalism, but in all cases, the relationship was marked by a degiee of permeability between the jurisdictional borders of each order of government, which in turn caused provinces to compete with one another, and with the federal government, in what would become known as "province-buildıng" or competitıve federalısm. It should be noted that these terms are not necessar1ly mutually-exclusive, and as noted later, each has its own meanıng and significance to the way New Brunswick pursues 1ts 1nterests.

During this time intergovernmental affarrs sought to leverage partnerships between orders of government at the political and bureaucratic level, despite jurisdiction. Despite periodic centralizing tendencies in Ottawa under Pierre Trudeau, ${ }^{213}$ Smiley noted that the

211 See Donald V. Smiley, Constitutional Adaptation and Canadian Federalism Since 1945, Royal Commission on Bilıngualısm and Biculturalısm, Vol. 4, Queen's Printer, 1970.

212 See Samuel V. LaSelva, The Moral Foundations of Canadian Federalism: Paradoxes, Achievements, and Tragedies of Nationhood, Montreal, McGill-Queen's Press, 1996: 175 citing J.R. Mallory, "The Five Faces of Federalısm," in P.A. Crepeau, C.B. Macpherson, (eds.), The Future of Canadian Federalısm, Toronto: Unıversity of Toronto Press, 1965.

213 Regarding the National Energy Program of October 28, 1980, see Patrick James, "Energy Politics in Canada, 1980-1981: Threat Power in a Sequential Game," Canadian Journal of Political Sclence, Vol. 26, No. 1, March 1993: 31-59; Bruce G. Pollard, "Canadian Energy Policy in 1985: Toward a Renewed Federalism?," Publius, Vol. 16, 1986; and Patrick James, Robert Michelın, "The Canadian National Energy Program and Its Aftermath: Perspectives on an Era of Confrontation," American Review of Canadian 
post-wat era was marked by a general diminution of the federal government's tendency to grab power for itself Durng this time provinces began asseiting then autonomy and influence through the intergovernmental process Smiley notes this devolution took place through "a process of contrnuous and precemeal adjustment between the two levels of government" and that these adjustments had been made through the "intetaction of federal and provincial executives" instead of through invocation of constitutional amendment or judicial interpietation ",214

Moreover, "Under cooperative federalism, the constitutional division of powers was preserved but federal and provincial ministers and public servants engaged in consultation and coordination to reach joint decisions on policies and programs of mutual concern "215 Hogg notes, "The related demands of interdependence of governmental policies, equalization of regional dispanties, and constitutional adaption have combined to produce what is generally referred to as 'cooperative federalism'."216 This cooperation is evident in the close workıng relationship between federal and New Brunswick minısters and bureaucrats, and avenues like jont program delivery, shared services, intergovernmental cooperation and other agreements of mutual benefit such as good-fatth negotiation in areas of shared jurisdiction

Studies, Vol 19, 1989 59-81 for valuable insight into the intergovernmental damage that was caused by the Trudeau government's intrusion into provinces' jurisdiction over energy policy

$214 \quad$ Smiley cited in Kernaghan, Siegel, 1991419

$215 \quad$ Kernaghan, Siegel, 1991419

216 Hogg, Peter, Constitutional Law of Canada, (4 ${ }^{\text {th }}$ edition), Toronto Carswell, 1996141 
This spint of cooperative federalism was emphasized in New Biunswick's Prospenty Plan which noted, "Federal-provincial cooperation is essential in order to accomplish our prosperity objectives as set out in Gieater Opportunıty New Bıunswick's Pıspen1ty Plan [ ] New Brunswickers want a cooperative, not a competitive approach between the governments, ${ }^{217}$ which in turn allows things to get done by both orders of government "without major transformation to their institutions "218

Executve Federalısm

As cooperative federahism and the interfacing of provincial and federal authoities continued from the late 1940s to the 1960s, provincral governments were revamped to reflect a higher professional standard, and a diminution of the conventional practice of partisan appointment, nepotism and cronysm Thus began the rise of the modern public service in New Brunswick, ${ }^{219}$ which in turn was reflected in an increased provincial government capacity for negotiatıng in a business-like fashion

217 Province of New Brunswick, News Release, "Mockler to Present New Brunswick's Prionties in Ottawa," January 2, 2004 Moreover, New Brunswick's Internatıonal Strategy notes, "We 1ecognize and support Canada's constitutional role in international relations We wish to have a dynamic and piogressive new partnership with the federal government as we pursue our province's international interests " Province of New Brunswick, Internattonal Strategy, 20037

218 Laza1, Telford, Watts, 20031

219 The highly aristocratic and exclusive character of New Brunswick's early Public Service resulted in high degrees of "institutionalized pationage," especially in the civil service, and indirectly supports the hypothesis that policy irrationality is historically lınked with New Brunswick policy-making based on personalızation and elite influence Thorburn notes that cliquish and closed social systems were the norm, suggesting value in considering theories of elite accommodation "Such a system of patronage and favouritism naturally led to the development of privileged positions for a few who, with their relatives, constituted a new Family Compact, shaing the spoils of government preferment" he wrote, 19619 Savole notes that by the 1980s, however, it could be sald 
As this new cadie became involved in representing New Brunswick's interests before the federal government, they cultivated extensive working relationships with their federal colleagues Interests were increasingly articulated to the federal government through senio1 bureauciats and executives rather than through legislators and their 1espective legislative assemblies and parliament Provincial executives liaised with federal counterparts, leadıng Smiley to the desciptive teim "executive federalısm" He noted it as "[ ] the relations between elected and appointed offrcials of the two orders of government in federal-piovincial interactions and among the executives of the provinces in intei-provincial interactions "220 Richaid Simeon defines executive federalism as the "bargaining and negotrating among the senior executives of the two ordets of government "221 Stevenson notes that executive federalism involves concentiation and centralization of authonty at the top of federal and provincial governments, the control and supervision of intergovernmental relations by politicians and officials with a wide range of functional interests, and the highly formalized and well-publicized proceedings of federal-provincial conference diplomacy 222

that, "New Brunswick has had a piofessional, non-partisan and career public service for a long, long t1me Indeed, its public service is a1 guably one of the best in the country" Savo1e, Pulling Against Gravity, 200175 While migration to a professionalized and ment-based public service was endeavoured, historic patterns of overt and subtle partisanship and political favouritism remain alongside an increasingly powerful bureaucracy with especially consideiable power over determination of international policies and practices in New Brunswick

$220 \quad$ Smiley, 198091

221 Richard Simeon, "Recent Trends in Federalism and Intergovernmental Relations in Canada Lessons for the UK?" in Salmon, Trevor C, Michael Keating, (eds ), The Dynamics of Decentralization Canadian Fedetalism and British Devolution, Montreal \& Kingston McGill-Queen's University Press, 200155

222 Stevenson cited in Kernaghan and Siegel, 1991419 
Although early Canadian federal-provincial interactions appeat limited to constitutional wiangling, fiscal agreements and jurisdiction guarding, they were nonetheless a function of policy dialogue where each attempted to maximize their individual autonomy and jurisdiction ${ }^{223}$ Given the lack of effective brokerage mechanisms for the representation of provincial interests within federal institutions in this envionment, executive federalism emerged as a viable means by which intergovernmental dialogue could transpue $^{224}$ More broadly, Chris Kukucha notes that the expansion of executive federalism resulted in a proliferation of government bureaucracies at both the federal and provincial levels In Ottawa these developments included the establishment of the Treasury Board as a separate department, new cabinet committees, expansion of the Privy Council Office and Pnme Minister's Office, and the creation of a Federal Provincial Relations Office in 1974.

In the provinces, the growth of intergovernmental machinery was often accompanied by international machinery. This accompanying trend did not happen simultaneously; frequently the former would precede the latter, but for the most part both machineries were seen as closely-related to another and important to exist jointly so that provincial interests inside and outside the nation-state could be pursued effectively. By contrast, the federal government appears to consider the pursult of fore1gn affairs and federalprovincial relations as both important but relatively unrelated. The construction of DFAIT's intergovernmental machinery reflects this, in that its Federal-ProvincialTerntonal division conducts provincial outreach in highly sporadic, non-systematized 223 Herman Bakvis; Grace Skogstad, (eds.), Canadian Federalism in the New Millennium, Toronto: Oxford University Press, 2002: 4-5 224 Smiley, 1987: 85 . 
ways, and opportunities to engage intergovernmental dialogue on international relations are telatıvely sparse, as will later be discussed Québec was the first province to organıze its bureaucracy to conduct intergovernmental and internatıonal relations By 1979 Alberta, Ontarı, Britısh Columbia, Newfoundland, and Saskatchewan all had therr own departments 1esponsible for intergovernmental 1elations that would at various points include an integrated international relations function. While budgetary considerations have slowed giowth of federal and provincial bureaucratic structures, Ottawa and several provinces continue to dedicate considerable financial and bureaucratic iesources into strengthening their capability to participate in international relations as they relate to areas of provincial jurısdiction ${ }^{225}$ all strong indicatıons of province-building tendencies in Canadian regional government paradiplomacy.

Executive federalısm is sometimes seen as antithetical to democratic norms in that while it encourages (or is the expression of) the bureaucratization of policy direction and engagement of intergovernmental officials in both central and regional governments, it disenfranchises elected offıcials' purview over policy processes. In a sense, executıve federalısm weakens the politicians' ability to play a direct role on the management of intergovernmental relations including those that impact on international policies, while on the same hand increasing the capacity for provinces to effectively pursue the province's writ large international interests. Van Loon and Whittngton back up this assertion, noting that "the evolution of executive federalısm is a symptom of the general

225 Christopher Kukucha, "Executive Federalism and the Federal-Provincial Committee System on International Trade A Tool for the Administration of Foreign Policy?," Univeisity of Lethbridge, Alberta, working draft of paper for publication purposes, 2003 3. 
impotence of legislatıve institutions vis-à-v1s the executıve branch." ${ }^{226}$ Ultımately, the significance of this impotence rests squarely in the elected officials' relative mability to substantially inform that which the government does outside the borders of the province, o1 state.

While executive federalısm may facilitate dispersion of power among various stakeholders in the inter-jurisdictional decision-making realm, "1t 1s manifested in the heavy concentiation of decision-making power in the hands of a very tiny political elite. ${ }^{227}$ In the case of New Brunswick's International Strategy, the interaction between provincral and federal officials, and the implied (if not overt) dependence on the federal government for assistance in strategy implementation, suggested prevalence of executive federalısm. This differed from past generatıons, when Minısters were involved in "broad policy issues, the detalls of policy, and even for the deta1s of the day."228

Though executive federalism is noted to have intensified since the 1960s and 1970s, which as noted earlier coincides with the first major entrances of Canadian provinces on to the international front, the first signs of its proliferation were noted in the 1960s. Eayrs, for example notes that in 1961 the senıor foreign affarrs civil servant "[...] has been drawn ever more intımately to the centre of the political process." 229 This observation is

\footnotetext{
$226 \quad$ Van Loon, Whittington, 1987: 520.

227 Van Loon, Whittington, 1987: 521.

228 Savore, Pulling Against Gravity, 2001: 77.

229 James Eayrs, The Art of the Possible: Government and Foreign Policy in Canada, USA: University of Toronto Press, 1961: 32. He further notes at 33, "At this exalted level the gaze of the crvil servant seeps across the whole horizon of public policy Thus the senior members of the Department of External Affarrs, with therr commanding position on interdepartmental committees and their unique relationship with the Prime
} 
significant, in that it provides a foreign affairs-oriented benchmark against which we can see attempts by the bureaucracy to take control and assume leadership over diplomatic matters. It is also significant to note in that while executive federalism lead to augmentation of the bureaucracy's power in domestic affairs, the increasing complexity of international affairs was exerting a parallel process in which more power was being accumulated by bureaucrats at the Ministry responsible for foreign affairs, ministers were playing a lessened role in determining Canada's policy directions, and policy-making itself was becoming subjected to specialized and technical direction (rather than political) direction. As will be later argued in this dissertation, a similar bureaucratization of New Brunswick's international policies would occur, functionally displacing elected officials from effective policy control and placing inordinate policy authority into the hands of bureaucrats.

While executive federalism has the effect of diffusing policy power between members of a relatively small intergovernmental bureaucratic community, it limits civil society's ability to play a meaningful role in policy development. Eayrs notes, "while the dominance of any one government is being reduced [...] the power of the state in general becomes more concentrated $[\ldots]^{, 230}$ As intergovernmental cooperation in international relations intensifies, the communicative efficacy of this small community has also grown, especially when considered in the light of increasingly sophisticated information

Minister's Office are assured of opportunity to influence decisions in areas far more extensive than a recital of their nominal responsibilities may suggest."

230 Van Loon, Whittington, 1987: 521. 
communications technologies (ICT) and the ability of bureaucratic executives to communicate and convene quickly and efficiently. ${ }^{23 !}$

Despite the shared experience of provinces negotiating inter-jurisdictional tensions between themselves and the federal government, lines of intergovernmental communication tend to be more federal-provincial, rather than inter-provincial. There have been some inter-provincial bilateral agreements to engage shared efforts in some foreign markets, such as the Memoranda of Understanding between New Brunswick and Manitoba in 2002. ${ }^{232}$ This was followed by Joint Premier-lead missions to the US and the Council of the Federation Premier-lead mission to China in 2008. Overall, however, devolution of international affairs in Canada can be argued to have paradoxically strengthened the hand of the federal government in international matters, rather than having weakened it, by virtue of the lack of cohesion and unity of provincial efforts on the global stage.

The executive function in the provincial government, as with the federal government, takes political and bureaucratic form. While the political component of the executive is conventionally seen as the initiator of policy-making and most likely to represent the

231 Simeon and Nugent reinforce the relevancy of historic observations as they relate to federalism in noting that "despite the massive changes that have occurred in the Canadian society and economy- globalization, multiculturalism, the mobilization of Aboriginal peoples, and the rise of non-territorially-defined social movements- the dynamics of executive federalism or 'federal diplomacy' today look remarkably like those that existed in the 1960s." In Bakvis and Skogstad (eds.), 2008: 90 citing Simeon, 2006: 314-32.

232 Memorandum of Understanding on Interprovincial Co-operation Between the Government of Manitoba and the Government of New Brunswick, Winnipeg, January 23, 2002. 
province's business abioad, this role has in New Brunswick latgely been relegated to the buieauciatic part of the executive This international policy decision-making tends to be concentrated in the bureaucracy for several teasons, including

a) High degiee of political risk compared to political gain for activities undertaken outside the province and countiy,

b) Political dangess associated with the populat equation and stigmatization of international travel as frivolous and unnecessat y by a largely iural population,

c) Oftentimes narrow majoities in the Legislature, as was the case during Loid's second mandate from 2003 to 2006 , which prevents seat-matching options that allow MLAs and Ministers to leave the House during sittings, and

d) Limited political gains for international successes versus being seen as a good "constituency MLA"

As a result of these forces at play, the New Brunswick public service has considerable involvement in international relations through intergovernmental channels, even with respect to New Brunswick's partıcıpation in La Francophonıe, where the Assistant Deputy Minister of IGA's Francophonie and Official Languages Bureau doubles as the Premiei's Sherpa Despite the benefits that come with cultivation of buieaucratic competence in dealing with international markets, the increasing prevalence of bureauciatic power in international relations takes politicians, CSOs and the attentive public out of the picture-Chapter 3 will discuss the limited extent to which the ISWG and IGA engaged in external consultations on the International Strategy's development 
Thus, for valious ieasons, New Brunswich buteaucrats have considerable power over provincial international relations policy The net effect of this is an inordinate degiee of power concentrated in the hands of the unelected and very few This dissertation goes on to discuss the dangers of small elite decision-making elites in a policy area of limited value and interest to politicians (after all, 1mportant policies get budgets), and the damage that is done to policy coherence and ratıonality, as well as intra-organizational tiust and morale as a result of unchecked centralization of power in cential bureauciatic agencies

Double-lmage federalısm

Analysıs of New Brunswick's international policies is given additional depth when its bilingual (English-French) and bicultural character are taken into consideration As Canada's only officially bilingual provincial jurisdiction, the provincial government has worked hatd to reflect this linguistic identity in its international activities in various policy fields that have a bearing on areas of federal junsdiction as well Moreover, the Province has sought and received federal government support for its activities within La Francophonie for a vaniety of strategic reasons as well

As such, the notion of "double-image federalısm" is highly relevant to this dissertation This way of looking at Canadian federalısm oinginated from an intensification of EnglishFrench, federal-piovincial conflict and cooperation startıng in the 1960s and reawakening of French nationalism in Québec and other piovinces with francophone populations With the Quiet Revolution having taken firm grip of the Fiench Canada's aspirations of quality 
and self-determination, Québec was determıned to be heard in a quasi-diplomatic, quasistate capacity on the world stage

This point is significant; it means the concept of double image federalism is stretched to include Québec's clarms as well as New Brunswick's, clarms for special conside1ation on the basıs of its linguistic and cultural duality From a strategic peispective and as later discussed, the fedeial government has looked to support New Brunswick's participation in the La Francophone as a means to migrate the double image federalısm model away from being Québec vs the rest of Canada to a more inclusive model that includes Québec, New Brunswick, and potentially other jurisdictions that have significant francophone populations.

This broad understanding of Canadian federahısm helps establish the intergovernmental relationship that informs this discussion of New Brunswick's international policies, and the relatıonships within which the Government of New Brunswick sees opportunities, is cognizant of challenges, and develops policies. Federalısm in Canada has been a dynamic institution, and with the effects of globalization drawing provincial governments into acting directly on the world stage, this has had implications on the federal-provincial government for several decades. It is notable, however, that the tone of this back-andforth between Ottawa and the provinces has become more than resolution and mediation of intergovernmental rancor borne of jurisdictional overlap, but rather has given rise to efforts by New Brunswick to position itself to benefit from conflict between the federal 
government and Quebec As Canddd's federal system contnues to evolve, and ateas of provincial juisdiction are incieasingly internationalized, the evolution will continue

This next section will discuss the concept of province-building and the Garbage Can Model of organizational design Both discussions are intrinsically telated to the main at guments of this dissertation outlıned in Chapter 1

\section{Province-building and the Garbage Can Model of Organizational Design}

\section{Unconventional Approaches}

As previously mentioned, study of regional governments' paradiplomatic efforts has not been accompanied by strong theories or explanations Common international relations theories like realısm, neo-realısm, interdependency and post-modernism have not been exceptionally effectıve at providing perspective on provincial internationalısm

The need, however, to attach theoretical and conceptual modeling to consideration of New Biunswick's international policies is significant As Stephen Walt notes,

It is hard to make good policy if one's basic organizing principles are flawed, just as it is hard to construct good theories without knowing a lot about the real world Everyone uses theories- whether he or she knows it or not- and disagieements about policy usually rest on more fundamental disagieements about the basic forces that shape international outcomes ${ }^{233}$

233 Stephen M Walt, "Inteinatıonal Relations One World, Many Theories," Foreign Pollcy, No 110, Special Edition Fionties of Knowledge, Spring 199829 
Keohane and Nye note that cross-pollination of domestic affars and international 1elations without application of organizational principles concerning intergovernmental affarrs and state structures, however, is counterproductive "It is termbly difficult to link domestic politics and the international system together theoretically without ieducing the analysis to little more than a descriptıve hodgepodge." ${ }^{234}$ Accordingly, we will look at two theoretical frameworks useful for analyzing New Brunswick's international policy province-bulding and the garbage-can model

Province-bullding

Attempts to provide a deeper understanding of forces at play in the Canadian federal system have given rise to many concepts, models and characterizations. One model that evolved in the late 1960s is "province-buldıng," which first appeared in the 1966 paper written by Black and Cairns, followed by another paper by Cairns alone. ${ }^{235}$ History has shown that although provinces are responsible for a wide range of activities of relevance to the common citizen, the federal spending prerogative and the goal of establishing national standards and programs frequently put the two orders of government at loggerheads with one another when inter-jurisdictional coordination and partnerships are required. The concept of province-building can be seen as a reaction by provinces to

234 Keohane, Nye, 1989: 303.

235 See Edwin R. Black, Alan C. Cairns, "A Different Perspective on Canadian Federahısm," Canadian Public Administration, 9, 1966. 27-44; Edwin R. Carns, "The Governments and Societies of Canadian Federalism," Canadian Journal of Politıcal Science, 10, December 1977, 695-725 for the first strong demonstrations of scholarship on the process of Canadian province-building. 
challenge the ubiquity and controlling tendencies of the federal government and advance theil interest in giowth, increased capacity and protection of jurisdiction

The following observation from Vengroff and Rich discusses how several provinces including New Brunswick have become mose internationally-active, but more importantly for this section (and as argued in the latter lines of the below citation), that they have devoted additional internal structures, resources and attention to strengthening the bureaucratic structure that pursues and operationalizes those object1ves.

There is considerable variation in the paradiplomatic involvement of the provinces, although they are in general highly implicated in international activity. There is no question that the most active provinces have been Alberta, Ontario and Québec, with New Brunswick as a more recent entrant to this top category. Some provinces have clearly attempted to assert themselves more fully in the international arena than others, but the important point is that in response to globalization all ten are in some manner or other heavily implicated and generally on a trajectory to increasing their involvement. The most active provinces [...] have a full complement of paradiplomacy related activities including international trade and investment missions, membership in cross-border associations of subnational (state-province) governments, and bilateral treaty-like agreements with national or subnational governments, and have their own representation abroad. These four provinces have also developed considerable bureaucratic expertise and invested in organizations (ministries, departments, or offices) to manage their international activities. ${ }^{236}$

Province-building in its original form as advanced by Black and Carns is generally acknowledged to be, or to have resulted from, the following characterıstics.

236 Vengroff and Rich, "Fore1gn Polıcy By Other Means," 2006: 116-7. 
a) The post-wat ise of the welfate state which accotded significance and juisdictional impottance to policy ateas constitutionally-assigned to the provinces through introduction of new socral progiams delivered by the provinces through conditional grants,

b) Provincial opposition to federal creep into areas of the1 juisdiction changed fiom being tolerant of such incuisions to thinly veiled impatience to open opposition and adoption of confiontational mechanisms including the Province of Québec's adoption of nationalistıc foreign polıcy and diplomatıc modus operand,

c) Piessure applied to Ottawa for gieatei inclusion into federal planning initiatives that would impact on the policy onentations and interests of the provinces,

d) Growth in provincial bureaucracies ${ }^{237}$ and cultivation of subject matter expertise, rapid provincial growth and pushes towaids capacity building, ${ }^{238}$ and

e) Greater coordination of provincial policies of their own and concurrent areas of jurisdiction

237 Growth in provincial bureaucracies was reflected in factors such as increased staffing-up of key departments and ministries resulting in greater size, increase in the roles and responsibilities of government, increase in the number of governmental ministries, and increased range of iesponsibilities adopted and/or accepted by government in ordet to serve the public

238 See Thomas F Keatıng, Don Munton, The Provinces and Canadian Foreign Policy Ploceedings of a Conference, University of Alberta, Edmonton, Alberta, 28-30 March 1985, A Jacomy-Millette, "Foreign Relations of Canadian Provinces," Library of Palliament Research Branch, Canada, 1984 Arthur Blanchette's chapter on "The Provinces and Fore1gn Policy," Canadian Fore1gn Policy, 1977-1992, Montreal McG1llQueen's Piess, 1994 137-152 is particularly useful, as it covers a number of timely and important 1ssues such as the international policies of Ontarıo, Alberta and Québec, La Francophonie, F/PT relations and provincial missions abroad Elliot J Feldman and Lily Gardner Feldman use their chapter "Canada" in Michelmann, Soldatos, Federalism and International Relations, 1990 176-210 to provide a global view of Canadian provinces' activities, but do not consider New Brunswick on account of a lack of material 
Nossal makes a connection between the phenomenon of provincc-bulding and foreign policy, noting that provinces' constitutional, socio-economic, functional and bureaucratic 1nterests may "propel provincial governments into the international sphere," ${ }^{, 239}$ which in turn strengthens theır resolve (especially in the case of Québec) to approach internatıonal affaiss as a means to strengthen their capacity to govern and exercise autonomy in areas of their constitutionally-defined jurisdiction. In the case of New Brunswick, the confluence of. a) growth in government, b) the federal government's interest in seeing New Brunswick more active and high profile in La Francophonie; and c) the increasing expectation that the provincial government would be involved in policy areas affected by internatıonal forces (such as out-migration of labour intensive employment to low labour cost countries such as Mexico (manufacturing) and India (call centres)) coincided with a greater emphasis on pursuing interests outside of Canada's borders.

In a volume devoted to discussing the era of competitive federalism in Canada, Cairns notes that by the 1960 s "provincial governments were no longer content to play the subsidiary, peripheral role of actors to which the nation-bullding definition of the country confined them, ${ }^{240}$ a fact he notes drew the Province of British Columbia into conflict with Ottawa over the former's desire to promote hydro-electric development of the Peace and Columbia river systems. The connection between piovince-bu1lding and international affarrs, however, appears to bifurcate in the 1960s into consideration of province-building and Québec-bulldıng, and by the time Nossal reprises the concept in 1989, the lion's

239 Nossal, The Politics of Canadian Foreıgn Polıcy, 1989: 259.

240 Alan C. Cairns, "Constitution-Making, Government Self-Interest, and the Problem of Legitımacy," in Allan Kornberg, Harold D. Clarke, (eds.), Political Support in Canada* The Crisis Years: Essays in Honor of Richard A. Preston, USA Duke University Press, 1983 388. 
share of academic dialogue connectıng province building and international relations takes place in the Quebec-building literature ${ }^{241}$

Discussions of province-building, therefore, relate to an elevation in the size, powet, organization and articulation of piovincial poweis in matters concerning a wide iange of policy areas both insıde and outsıde provincial juisdiction Black and Carns argue that province bulding has been a continuing dynamic since Confederation, at which time John A MacDonald aspired to a process of nation building that would culminate in a strong Canada characterized by a highly centralized government, with the power of the provinces gradually whittled away to little more than delivering administrative functions of the state

Stevenson points out that the nation-building (economic nationalism) envisaged by MacDonald had the effect of "intensifying internal patterns of interdependence and [ ] regulating ties with the outside world ${ }^{\prime 242}$ Provincial opposition to this end-goal and an insistence on protecting their respective jurisdictional sovereignty and autonomy "justified a vigorous program of province-building "243 Other works by Stevenson and Chandler and Chandler, more closely examine the confluence of social, cultural and political 1ssues duing the 1960s and early 1970s which are viewed as the period most

241 See for example Kornberg, Clarke, (eds), Political Support in Canada, 1983, Chapter 4, Nossal, The Politics of Canadian Foreign Policy, 1989 266-275

242 Stevenson, Unfulfilled Union, 2004180

243 Samuel V LaSelva, The Moral Foundations of Canadian Federalısm Paradoxes, Achrevements, and Tragedies of Nationhood, Montreal, McGill-Queen's Press, 1996 173 
associated with active province-building ${ }^{244}$ Bantıng points out that during this time provincial governments "fought to recapture tax room on therr own terms In effect, the struggle was for control over the Canadian welfare state $" 245$

While the province-bulding debate has waned since the 1960s and 1970s, 1ts ielevance to New Biunswick's international activities is instructive Diawing on the differences between strong and latge provinces and smaller, weaker ones, Elkins, Simeon and Blake concluded in 1984 that "In Atlantic Canada, the dependency on federal assistance has also led to a less aggiessive stance towards Ottawa "246 In speakıng about the dispıoportionate power large provinces have traditionally had in Canada, Leach notes that, "the smaller Atlantic provinces have felt the brunt of the imbalance They have historically tended to look to Ottawa for much of therr sustenance and, to a large degree, have become dependent on Ottawa for survival, 247

Young, Faucher and Blais delivered a systematic and comprehensive critique of the concept in 1984, convincingly arguing that "this emotive and misleading concept be

244 See Garth Stevenson, Unfulfilled Unıon Canadıan Federalısm and National Unity, $4^{\text {th }}$ edition, Montreal, McGill-Queen's Piess, 2004, Marsha Chandler, William Chandler, "Public Administration in the Provinces," Canadian Public Administratıon, 25, 1982 585, note "The maturation of the provinces, often referied to as province-building, 1s without doubt among the most far-reaching of the tiansformations"

$245 \quad$ Ketth G Bantıng, "The Three Federalısms Social Policy and Intergovernmental Decision-Makıng," in Herman Bakvis, Grace Skogstad, (eds), Canadian Federalısm Peiformance, Effectiveness, and Legitimacy, $2^{\text {nd }}$ Edition, Toronto, Oxford University Press, 2008 140-141

246 David J Elkins, Richaid Simeon, (eds), Small Worlds Provinces and Parties in Canadian Political Life, Taylor \& Francis, 1980298

247 Richard H Leach, "Canadian Federalısm Revisited," Publuus Crisis and Contmuity in Canadian Federalısm, Vol 14, No 1, Winter 198411 
abandoned "248 While they agreed that federal provincial relations had evolved with the flexing of new political muscle in the provinces, Young et al did not believe province building was a valid paradigm anymore On this point, however, it is atgued below that province-building has a useful role to play in helping us understand New Biunswick's international policies

In particular, Young et al maintain that province-building advocates make six propositions that are problematic, and ought to be challenged They include arguments that provinces have iesisted federal incuisions to areas of provincial jurisdiction, increased human and financial capacity to dehver services in relation to the federal government, have deeper and wider spending powers, centralızed polıcy makıng, are most closely linked with resource industry sectors, and that province-building conflicts with nation-building Instead, they argue that provinces tend to demonstrate docility on jurisdictional matters (787), despite increased revenues provinces actually have less discretionary spending powers (795-798), perception of increased provincial spending power is mitigated by the fact that much of that new spending power comes in the form of conditional giants, centralization is mitigated by the rise of New Public Management (NPM) delivery techniques and intragovernmental differences on spending priorities, resources account for a small portion of provincial revenues (805), and that a zero-sum view of federalısm as being fundamentally uncooperative should not dominate (810)

248 Robert A Young, Philippe Faucher, Andie Bla1s, "The Concept of Province Buılding A Critique," Canadian Journal of Political Science, Vol 17, No 4, December 1984785 
Despite these a1guments, howeve1, the discussion of province building that follows establishes that it is difficult to understand provincial engagement in international affais without using the province-bulding lens, and as such, the ise of paradiplomacy gives the ptovince-bulding thesis new life To illustrate the point, Young et al's counter-atgument that provinces demonstiate docility on juisdictional matters may have weight in a domestic context, but when applied to international policies, falters

To the contrary, much of provincial international policy is done to discourage federal interference in provincial areas of jurisdiction Watts cautions that the constitutional distribution of powers has been troublesome in certain areas, most notably in "foreign affairs where, in many federations, federal jurisdiction may be used to overnde jurisdiction that would otherwise belong to the regional governments "249 For example, as demonstrated by the federal government's engagement in the Kyoto Protocol process despite protestations by provinces that environmental policy is an area of provincial Jurisdiction, it is evident that areas of provincial jurisdiction are of interest to the Government of Canada, ${ }^{250}$ resulting in pressures on the provinces to realize they have clear and new stake in renegotiatıng how Canada's foreign policy is configured and pursued Fry notes this intersection of fedeial and provincial international interests, and recognizes its impact on provision of effective national governance

\footnotetext{
$249 \quad$ Watts, 199940

250 While iatification of the Kyoto Piotocol 1s a recent example of this challenge, tensions over the limits and parameters of intergovernmental international iesponsibilities and jurisdictions date back to the early 1930s The Centie for Research and Information on Canada (CRIC) notes that while the majoitty of Canadians support the ratification of the Kyoto Protocol, "[ ] 52\% say that the federal government should delay iatification unt1 agreement is teached with all the provinces" CRIC, 2002
} 
[ .] as decisions are made and events transpire outside the boundanies of the nation-state that may have an immediate and profound effect on citizens at the grass roots level, these citizens demand that therr interests be protected and enhanced not only by their national governments but also increasingly by the subnatıonal governments closest to where they live. ${ }^{251}$

Provinces build themselves up through international relations to discourage federal interference in provincial areas of jurisdiction, but they do so with varying resources. In the case of larger provinces, a more forward strategy might be followed In the case of smaller provinces, other more collaboratıve and cooperatıve measures may be required to convey the same message- that federal incursions are unwanted Hence, New Brunswick's model of province-building in international affairs will be shown to be distinctly different from that of larger provinces, a line of argument that will resurface later in this dissertation.

\section{Garbage Can Model}

Another important theoretical framework that is employed in this analysis of New Brunswick's international policies and practıces is the Garbage Can Model.

While this dissertation was originally conceived of as a study with which to examine New Brunswick's International Strategy, it was predicated on the assumption that there was a logical relatıonship and ratıonale ${ }^{252}$ between strategıc desıgn formulation prioritıes

\footnotetext{
$251 \quad$ Fry, 1998. 15

252 Rationale- noun "A set of reasons or logical basis for a course of action or a belief." Compact Oxford English Dictionary, URL: http://www.askoxford.com; Accessed: January 2009.
} 
such as a) problem design and resource allocation, b) intia and inter-bureaucratic engagement, and c) resouice (human and financial) acquisition for the purpose of suppoiting policy implementation As this study of New Biunswick's International Strategy and international policies plunged deeper into the subject matter, there giew a concern that conventional theories and conceptual models focussing on collaborative federalism and province-burlding alone would not be surtable for answering simple questions such as

- Was the International Strategy ratıonal?

- Why did it seek certain solutions over others?

- Would proposed action priorities accomplish the intended objectives?

- Does increased executıve federalısm result in policy 1rrationality?

A further concern drew into focus concerns over policy evaluation, and the extent to which conventional theories could be used to analyze non-economic policies of government Consider the following regarding economic decisions Provincial government policies relating to expenditure of budgeted financial resources are subject to legislative oversight and attention by the Opposition, attentive public and Office of the Auditor General Ratıonal actor and principal agent theories of organızatıonal design help decipher what government's interests a1e, how policy is developed and resources are allocated in response to emerging 1ssues, and whether policies undertaken pass various forms of cost-benefit analysis and standard accounting processes Adherence to standard 
accounting practices (for the most part) underpins the work of government and provides a basis for quantitative analysis.

In the case of non-economic policy, however, lack of similar institutionalized oversight mechanisms make it difficult to conduct process and impact evaluations related to that policy's implementation, and draw into use more qualitative methods of analysis. In addition to the inherent subjectivity involved in such forms of policy analysis, the conduct of this work is either left to government to conduct as per its own devices and to serve its own interests, or becomes the task of think tanks, civil society organizations or academia, all of which exist in short supply in New Brunswick. With regard to New Brunswick's International Strategy, how would even the most objective assessor make sense of the underlying suspicion that the International Strategy was logically flawed, and that a fulsome analysis would require an organizational theory that was flexible enough to account for irrationality, circumstantial decision-making and ad hocery? What theories and models pertaining to decision-making chains could be employed to examine the possibility that solutions did not follow issue identification?

Generally speaking, the rational actor concept could have been used to examine New Brunswick's International Strategy as a tool by which the Province sought to realize certain policy or interest-based objectives. Applied to government decision-making and from an organizational perspective, Allison's 1971 analysis $^{253}$ (for example) of bureaucratic decision-making during the Cuban Missile Crisis through the lens of

253 Graham T. Allison, Essence of Decision: Explaining the Cuban Missile Crisis, Michigan, Little, Brown Publishing, 1971. 
government as a "iatıonal actor" might have had relevance in helping explain provincial decision-makeis balance the costs, 11sks and benefits inherent to adopted policies The problem with applying this approach to the study of the inter-and intra-governmental governmental implications of New Brunswick's International Strategy process, however, is that 1ationality is a relative and peispective-based concept, what seems enturely logical and rational to one buieaucratic organization (and the individuals that comprise their ranks who regularly deal with one another) may be seen as irrational to another as each would have its own understanding of rationality.

If we were to apply the concept of rationality to look at New Brunswick's International Strategy as the product of rationally-minded bureaucrats acting in a fashıon to maximize their own self interest, we might accept the argument that individuals and groups of individuals can act as "self-1nterested, short-term maximizers." 254 In takıng such an approach, we might have eschewed concentrating on institutional and philosophical lenses through which to decode political and policy onentations, and instead sought to focus on analysis of individual choice and interests and the reasons for those choices. By extension, we would also keep in mind that organizational pursuit of public interests by bureaucracies is done by rational indıviduals workıng in cliques and organized networks that share self-interested goals such as strategically-promoting another, accumulation of decision-makıng power and flexing organızational mandates to conform with their own desires and inclinations In this extrapolative way we can see that the rational pursuit of

254 Elinor Olstrom, "A Behavioural Approach to the Rational Choice Theory of Collective Action," in Michael Dean McGinnis, (ed.), Polycentric Games and Institutions Readings From the Workshop in Political Theory and Policy Analysis, USA, Un1versity of Michigan Press, 2000: 474 
individual goals by elites within the New Biunswick public service has a deep impact on the way that government organizatıons pursue publıc inteıests The ratıonally-minded and calculative c1vil servant, in fact, pursues public interests as a mechanism and means with which to advance individual goals and aspirations.

In this particular view, as is the case when economists view people making marketoriented choices, decision-makers are viewed as acting "in a rational and calculating fashion to maximize their own interests."255 Moreover, by adopting this approach to analyzıng government policy, ratıonal government decisıon-makıng can be interpreted as having the following three characteristics: a) primary unit of political action is the individual; b) small groups can organıze and mobilize in support of their objectives easier than others; and c) government is not viewed as a neutral political arbiter but rather as a self-interested actor in its own right seeking to advance its own interests. ${ }^{256}$

In terms of bounded rationality frameworks, however, it is acknowledged that rational decision-making is not always possible, with emphasis on instances in which rational decision-makers may not be privy to certain information needed to make rational decisions, or need to make decisions outside the realm of their abilities. ${ }^{257}$ The underlying

255 Robert J. Jackson, Doreen Jackson, Politics in Canada: Culture, Institutions, Behaviour and Public Policy, $6^{\text {th }}$ edition, Toronto, Pearson, 2006: 509-510.

256 See Michael J. Trebilcock et al, The Choice of Governing Instrument: A Study Prepared for the Economic Council of Canada, Ottawa, Supply and Services, 1982. 10 cited in Jackson and Jackson, 2006. 510.

257 See for example Richard Cyert, James March, A Behavioural Theory of the Firm, Prentice-Hall, New Jersey, 1963, or Herbert A. Simon, "Rationality in Political Behaviour," Polntical Psychology, Vol. 16, No 1, 1995: 45-61 who notes, "By a weak definition of rationality, virtually all human behaviour is rational." (45) Some critics of GCM, such as Bendor et al noted below, argue that Garbage Can modeling is more 
assumption, however, is that the decision-maker is a rational and self-interested being, and that decision-making processes seek to provide rational decisions within the scope in which time and knowledge are possessed

Regardless of what approach we use to examme the rationality of the International Strategy, be it fiom an policy, individual or organizational perspective, the hypothesis has been advanced that New Brunswick's policy efforts in international relatıons sometımes seems less then enturely sensible, rational and well-thought out, and as will be demonstrated in later chapters dealing with action priorities introduced by the International Strategy. González cites Klaus Knorr's observation that "it is useful to distınguısh among ratıonal, emotional, technically mistaken, irratıonal, and apparently irrational behaviour. Most of the times a complex behaviour- as the one usually observed in international politics- is a mixture of all of them.."258 Hastie and Dawes note that Irrationality in decision-making can be identified by the presence of the following criteria: a) habit or choosing what we have chosen before; b) conformity, or making whatever choice most other people would make; or c) cultural mandates, as may have been taught by other authorities. ${ }^{259}$

accurately understood as a variant or strain of bounded rationality, a point vehemently countered in a scathing response to the critique See Johan P. Olsen, "Garbage Cans, New Institutionalısm, and the Study of Politics," American Political Science Review, Vol. 95, No. 1, March 2001: 191-198.

258 Servando González, The Nuclear Deception· Nikıta Khrushchev and the Cuban Missile Crisis, InteliNet/InteliBooks, 2002: 229.

259 Re1d Hastie, Robyn M. Dawes, Rational Chorce in an Uncertain Age: The Psychology of Judgment and Decision Making, Sage, 2001: 18 
To help make sense of 1national policy-making, the Garbage Can Model (GCM) as originally conceived by Cohen, March and Olsen in 1972 was based on the premise that the actions of government cannot always be interpreted or analyzed as the end-product of deliberate, rational and calculated decision-making, even in cases where relevant knowledge and time requited to make decisions are avallable. Instead, they aigued,

To undeistand processes within organizations, one can view a choice opportunity as a garbage can into which various kinds of problems and solutions are dumped by participants as they are generated. The $\operatorname{mix}$ of garbage in a single can depends on the mix of cans avarlable, on the labels attached to the alternative cans, on what garbage is currently being produced, and on the speed with which garbage is collected and removed from the scene. ${ }^{260}$

Government decision-making was described as "a collection of chorces looking for problems, 1ssues and feelings looking for decision situations in which they can be the answer, and decision makers lookıng for work,"261 all the while keeping in mind that there is a critical difference between rational decision-making that is erroneous, and decision-making that is fundamentally irrational.

In then review of GCM, Bendor, Moe and Shotts note that the theory is based on the supposition that some individuals cannot be considered entirely rational, or even as individuals that care about solving problems. ${ }^{262}$ When we look at the garbage can model,

260 Michael D. Cohen, James G. March, Johan P. Olsen, "A Garbage Can Model of Organizatıonal Choice," Administratuve Science Quarterly, Vol. 17, No. 1, 1972. 2. 261 Ibid.

262 Jonathan Bendor, Terry M. Moe, Kenneth W. Shotts, "Recycling the Garbage Can: An Assessment of the Research Program," The American Polutical Science Review, Vol 95, No. 1, March 2001: 174. 
the government is seen as a "garbage can" into which a panoply of solutions to not-yet occuned problems opportunities and policy alternatives are generated and deposited Farazmand notes that process becomes more important than the problem in this tarl wagthe-dog inversion of conventional policy development piocesses, "In fact, goals tend to appear and take shape after the fact emerges fiom the process "263

The main value-add that GCM plays in our consideration of New Brunswrck's International Strategy, and the reason that it was chosen as opposed to other theories that may have been used herein, is that it actively diverts our attention away from the highlycalculated and strategic policy design and conceptualızatıon processes we assume exist, and towaids an organizational model that is based on circumstances, situation, fallible individualism and spontaneity It can also be adapted to incorporate within its explanatory framework the effects of elite accommodation and executive federalism, and the effects of political centralization and marginalization of the attentive public This organizational model encouraged analysts to rethink the way they viewed decisionmaking, and towards the understanding that public policy was not always intentional, rational, comprehensible and predictable Instead Cohen, March and Olsen raise the possibility that there is very little about some policy development that is screntific and rational, but rather, that they may be the epitome of selious gaps in logic

In examining the work of Cohen, March and Olsen, Howlett, Ramesh and Perl point out that actors may "simply define goals and choose means as they go along in a policy 263 Alı Farazmand, (ed), "Emergent Theories of Oiganization An Overview and Analysis," Emergent Organizations, $2^{\text {nd }}$ edition, USA, Greenwood Publishing Group, 200264 
process." 264 Citing Mucciaroni, Howlett, Ramesh and Perl also observe that "what gets on the agenda at given points in time is the result of a fortuitous conjunction- whatever the combination of salient problems, available solution, and political circumstances that exist." ${ }^{265}$ Cohen, March and Olsen make the argument that their GCM is best suited to respond to instances where institutions are fraught with difficulties related to their own inherent "organizational anarchy," which is characterized when:

a) It is difficult to impute a set of preferences to the decision situation that satisfies the standard consistency requirements for a theory of choice;

b) Its own processes are not understood by its members; and

c) Participants vary in the amount of time and effort that they devote to different domains; involvement varies from one time to another. ${ }^{266}$

The anarchy mentioned by Cohen, March and Olsen is particularly obvious in public organizations $^{267}$ with studies of seven universities forming the basis of the concept, and upon which they observed decision-making that was so ad hoc and uncoordinated, that they felt justified in pursuing the hypothesis that it would be fundamentally incorrect to label such policies as undergoing incremental metamorphosis, or as being rational. In the GCM model, the authors identified four "streams" within an organization, one or more of which could stimulate the ad hocery they observed,

264 Michael Howlett, M. Ramesh, Anthony Perl, Studying Public Policy, $3^{\text {rd }}$ ed., Toronto: Oxford University Press, 2009: 152.

265 Howlett, Ramesh, Perl, Studying Public Policy, 2009: 152 citing Mucciaroni, 1992: 461.

266 Cohen, March, Olsen, 1972: 1.

267 Ibid. 
- Problems- organicational ability to understand real-hife issues affecting the or ganization,

- Solutions- sometimes answers to questions exist before the questions are evident, which themselves end up formulated to fit solutions that are at hand,

- Participants- variations in the composition of those involved in decision-making introduces valiability and unpiedictability in policy design, and

- Chorce opportunities- instances when the organization forces itself to make decisions, policy or otherwise, based on occasions to make those decisions itself declares 268

One of the most significant critiques of GCM comes from Bendor, Moe and Shotts, who argue that "the theory that has giown up ove1 the years 1s so complex and confusing, and some of 1ts components are so seriously flawed, that there is little reason for thinkıng that it can look ahead to a more fertile future." 269 While their analysis covers nearly every aspect of Cohen, March and Olsen's GCM mode, in partıcular, Bendor, Moe and Shotts focus their comments to two aspects of organized anarchy The first challenges the notion that decisions are not meant to resolve problems, but rather are symptomatic of a flight reaction or oversight by decision-makers The second perspective that they challenge is the assertion that decision makers tend to track one another and make decisions in a coordinated fashion, an aigument that Bendor, Moe and Shotts maintain is inconsistent With the inheient uncoordinated chaiacter of $\mathrm{GCM}^{270}$

Cohen, March, Olsen, 19723 
Othes critics of GCM such as Mucciaroni admit that it can still have applicability in particular markets. and that political and social context are extremely important factors, "Perhaps the mode of policy-making depicted by the Garbage Can model is itself embedded in a particular institutional structure "271 Unlıke the United States where Mucciaronı sees that there is GCM applicability due to the fragmented, pluralistic and flu1d nature of 1ts organization, ${ }^{272}$ he notes that in other countries GCM's relevance is less so given gieater degrees of policy centralızation, integration, limited participants to policy articulation and political and bureaucratic engagement that is structured and predictable Whethei or not that is true, Canadian intergovernmental relations may be sufficiently fragmented to give applicability and functionality to the GCM model ${ }^{273}$

New Brunswick's efforts to coordinate intra-departmental and intergovernmental collaboration on the development and articulation of the International Strategy draw into question the rationality and intent of the Strategy, its framers, and the process and end result of consultations to develop the Strategy Along with the theory of provincebuilding, Chapters 3 and 4 will explore instances in which GCM has explanatory functionality, and Chapter 5 will provide analysis of how the theory helps shed additional light and knowledge of New Brunswick's International Strategy and related processes

$271 \quad$ Mucciaron cited by Howlett, Ramesh, Perl, 2009153.

272 Conceivably a functional by-product of its considerable degree of powers and ${ }_{273}$ redilection towards policy politicization.

273 Application of John W Kingdon's Multiple Stream Theory (1984) was considered, however, lack of sufficient data on the political stream at time of writing made it non-viable See Agendas, Alternatives, and Public Policies, Boston: Little Brown, 1984. 


\section{Chapter III: New Brunswick and its International Strategy}

This main area of concentration for this dissertation 1s New Brunswick's International Strategy, therefore, the goal of this Chapter is to analyze that policy undertaking in deta1l, as well as examine some of the organizational decisions and initiatives pursued under its aegis. In addition to examining aspects regaiding the design and execution of the Internatıonal Strategy (and its orıgins found in the Pıovince's Prosperty Plan), this chapter provides some general facts about the piovince in order to provide a degree of background context.

As suggested in Chapter 1, there ate few foundational academic works that deal specifically with New Brunswick's system of government, process of policy articulation and intergovernmental and inter-jurisdictional relations and processes ${ }^{274}$ (let alone paradiplomatic activities). This chapter therefore provides some political and socioeconomic background upon which Chapter 4 is based, so that challenges it faces with respect to its international policy are better understood Bulding on this foundation, the

274 Donald J Savore's discussion of ACOA's predecessor, the Department of Regional Economic Expansion (DREE), in Federal-Provincial Collaboration: The Canada-New Brunswick General Development Agreement, McGill-Queen's University Press: Toronto, 1981, provides great insight into how the federal government approached intergovernmental relations with the Province, a relationship influenced by the federal government's treatment of it as a conservative-minded, have-not and backward province with respect to its politics and economics, which in turn was manifested in DREE's forward (if not aggressive and controlling) approach to the intergovernmental relationship. Also see H.G Thorburn, Politics in New Brunswick, University of Toronto Press: Toronto, 1961; P.J. Fitzpatrick, "New Brunswick: The Politics of Pragmatism," in Martin Robin, (ed.), Canadian Provincial Politics. The Party Systems of the Ten Provinces, Prentice-Hall: Scarborough, 1972; Dav1d J. Bellamy, "The Atlantic Provinces," in David J. Bellamy, Jon H. Pammett, Donald Cameron Rowat, (eds.), The Provincial Political Systems: Comparatıve Essays, Cambridge Unıversity Press, 1976: 3 18. 
next chapter of this dissertation will proceed to analyze three policy areas ${ }^{275}$ in which piovincial and federal interests intersect- tiade and investment immigiation and membership to and participation in La Francophone

Let us begin with some basic facts and history about New Biunswick and its place in the Canadian federation The following table provides some basic demographic information on the province

\begin{tabular}{|l|l|}
\hline \multicolumn{2}{|c|}{ New Brunswick- General Information } \\
\hline Capital & Fiedericton \\
\hline Population & 760,000 ( $8^{\text {th }}$ largest of 10 provinces $)$ \\
\hline Ared & 28,355 squdie miles $\left(8^{\text {th }}\right.$ ld1 gest of 10 provinces $)$ \\
\hline $\begin{array}{l}\text { Labour } \\
\text { Folce }\end{array}$ & 385,000 \\
\hline $\begin{array}{l}\text { Borde1 } \\
\text { Length }\end{array}$ & 513 kilometres \\
\hline Major C1t1es & $\begin{array}{l}\text { Fredericton, Saint John, Moncton, Edmundston, } \\
\text { Miramichi, Dieppe, Bathurst, Campbellton }\end{array}$ \\
\hline $\begin{array}{l}\text { Key } \\
\text { Industries }\end{array}$ & $\begin{array}{l}\text { Aerospace/Defence, Custome1 Contact Centres, } \\
\text { Environmental Products, Food Processing, } \\
\text { Knowledge Industries, Metalworking, Mining, } \\
\text { Plastics, Text1les, Value-Added Forestry, } \\
\text { Agricultural, Fisheries and Agiculture }\end{array}$ \\
\hline
\end{tabular}

275 New Brunswick's pursuit of international development activities is briefly mentioned within the context of its membership to La Francophonie despite considerable vocational training done by the NBCC as part of its international development and curriculum sales objectives

276 Piovince of New Brunswick general facts and figuies, URL http //www gnb ca, Accessed September 12, 2008 


\section{Brief Mistory}

The fist European landing on North America so1l on what is presently New Biunswick was in 1604, at which time the tellitory was inhabited by Micmac and Maliseet aboirginal people Led by Samuel de Champlain, early French immigrants landed at what 1s today the Isle St Crorx, and gradually migrated up-11ver to the Fredericton area When wat bioke out between the English and French in Europe in the 1750s, Fiancophones (known as "Acadıans") were collectively exıled ${ }^{277}$ for fear by the Britısh Crown that they would ally with Fiance Many of the exiled eventually ieturned to New Brunswick and settled in northern and coastal regions along the Gulf of St Lawience and Bay of Chaleur ${ }^{278}$ This co-habitation resulted in New Brunswick's designation as Canada's only officially bilingual jurisdiction and other legislative measures to ensure the province's biculturalısm and linguistic duality

In 1783 the Amencan Revolution resulted in the northwards migration of settlers wishing to remain loyal to the Britısh Crown Many of these "Loyalısts" settled in Saint John, Canada's first incorporated city, and had significant demographic impact Robertson

277 Literature associated with the "Expulsion of the Acadians" is reviewed by Barry Moody, "Acadia and Old Nova Scotıa to 1784," in Martın Biook Taylor, Doug Owram, (eds), Canadian History Beginnings to Confederation, $2^{\text {nd }}$ ed, Toronto University of Toronto Press, 1994 100-102 Also see Naomi Griffith, The Acadians Cieation of a People, Toronto McGraw-H1ll Ryeıson, 1973

278 It should be added that the expulsion has significant historical value in New Brunswick, and is identified by Bellamy as the "second major cultural fragment existing in the Marıtımes," the fi1st being between Loyalısts and non-Loyalısts See Bellamy, "The Atlantic Provinces," in Bellamy, Pammett, Rowat, 197612 While this acrimonious history does not affect English-French relations in New Brunswick, the administrative state has adopted several measures (later discussed) to ensure that both languages are reflected in the trappings and functions of the provincial government apparatus 
notes that "New Biunswick has long been referred to as the Loyalist province because the 14,000 Loyalısts who were directed there far outnumbered all other inhabitants [they] placed their impint on the new colony at once ${ }^{~ 279}$ The 1800 s brought major waves of Eu1opean 1mmigiants fiom Scotland and Ireland to New Brunswick, followed by migiants of largely Caucasian backgiound Beginning in the 1960s and contınuing to the present date, New Biunswick's immigiant composition diversified as the iesult of relaxation of immigiation laws for non-European migrants, and includes modest influx of migiants fiom China, India, South Korea and the Carıbean ${ }^{280}$

The Lieutenant Governor is the Queen's representative in New Brunswick and formal head of state 55 Members of New Brunswick's Legislative Assembly compise the legislative branch of government New Brunswick has 10 seats in each of the appointed Senate of Canada and elected House of Commons Local municipal governance, which is regulated by the Province, is administered by 8 cities, 28 towns and 68 villages Smaller rural communities without critical mass for dedicated municipal councils are collectively governed through aggregated Local Service Districts (LSDs)

In terms of policy jurisdiction, the Province is constitutionally mandated to provide its residents social services including education, housing, health, income assistance and

279 Ian Ross Robertson, "The Maritime Colonies, 1784 to Confederation," in Taylor, Owian, (eds ), Canadian History, 1984243

280 John Mercer, "Canadian Cities and The11 Immigrants New Realities," Annals of the American Academy of Political and Social Science, Vol 538, Being and Becoming Canada, Sage Publishing, March 1995172 
justice thiough diect involvement ${ }^{281}$ New Brunswick has lour public universities ${ }^{282}$ and a piovincial community college system that piovides vocational and applied training in engineering, licensed tiades, information technology and fine arts Publıc education goes from Kindergarten to Grade 12 and is offered in English and French, administered at the local level The significance of these services is relevant to Chapter 4, as New Brunswick has leveraged its juisdiction in these policy fields as a basis for its international policies and practices

Economy

Toursm constitutes a $\$ 1$ billion per year industry and key component of the provincial economy ${ }^{283}$ As the province 1 s roughly $85 \%$ forested, another major driver of the New Brunswick economy is the forestry sector, which accounts for the direct and indirect employment of approximately 23,000 people with wages estimated to be $\$ 1.1$ billion annually. The industry on whole injects the provincial economy with $\$ 2.1$ billion (11.2\% of provincial GDP), comprising 40\% of provincial exports and bringing in $\$ 264$ million in provincial tax revenues. ${ }^{284}$ In additional to providing hard and softwood products, New

281 See Keith G. Banting, Richard Simeon, (eds), And No One Cheered Federalism, Democracy and The Constitution Act, Toronto: Methuen, 1983, and also, Chapters 2 and 3 of Richard Simeon, Division of Powers and Public Policy, Royal Commission on the Ecomomic Union and Development Prospects for Canada, Toronto: Toronto University Press, 1985.

282 Unıversity of New Brunswıck, Unıversité de Moncton, Saint Thomas Unıveisity, Mount Allison University

283 New Brunswick Department of Tourısm and Parks, Province of New Brunswick, 2006-7 Annual Report, November 20072

284 New Brunswick Forest Products Association, "New Brunswick Forestry at a Glance," Hugh John Fleming Forestry Centre, Fredericton, New Brunswick, 2008 publication. 
Brunswick has capabilities in forest management techniques and practices. From an industrial perspective, New Brunswick's minerals and mines industry employs over 3,500 people and has export revenues in metals (ex. copper, lead, zinc), non-metals (ex. peat moss, potash, silica), fuels (ex. coal), and structural materials (ex. lime, sand and gravel, stone).

Commercial fishing and shellfish harvesting contributes to the province's natural resource-oriented economy. In 2006-7, the fisheries industries comprised over $\$ 795$ million in exports, with a total production value of seafood and seafood-related products at $\$ 1.1$ billion. The industry also provides employment for over 12,000 people, supplemented by indirect employment in areas such as transportation and manufacturing. ${ }^{285}$ Agriculture is an equally important economic pillar in New Brunswick, and in 2007-8 constituted approximately $\$ 444$ million in farm cash receipts, $\$ 1.3$ billion in processed food and beverage shipments and accounts for approximately $10 \%$ of New Brunswick's total industrial output. Many of the roughly 17,000 jobs created directly and indirectly in this sector are in rural areas of the province. ${ }^{286}$

Electric power generation and distribution is managed by the New Brunswick Power Corporation, a provincial Crown Corporation connected with electrical utilities in 285 New Brunswick Department of Fisheries, Province of New Brunswick, 2006-7 Annual Report, November 2007: 5. It is there noted that inter-jurisdictional implications are relevant to this mainstay of the provincial economy. "While management of the resource remains the responsibility of the Department of Fisheries and Oceans Canada, the New Brunswick government plays a very pro-active role in advocating for fair and equitable access to this public resource. New Brunswick has jurisdiction once the resource is landed at the wharf."

286 New Brunswick Department of Agriculture and Aquaculture, Annual Report 2007-2008, 2008: 8 . 
Québec, Nova Scotıa, Pınce Edwad Island and New England, and utılizes hydro, theimal. combustion turbine and nuclear plants.

Many of New Biunswick's traditional economic activities are significant in that global market integration has iesulted in highly volatile commodity pice changes and fluctuations whose negative implications have resulted in social and economic consequences for New Brunswick For example, two textrles companies owned by the Sunflag Group of the UK that located in northern New Brunswick (Atlantic Yarns which opened January 1998 and Atlantic Fine Yarns which opened February 2000) after high profile announcements ${ }^{287}$ were forced to seek bankruptcy protection from the Court of Queen's Bench of New Brunswick on October 26, 2007. ${ }^{288}$ Therr respective farlures were blamed on damaging global market forces such as diminished textıle commodity prices; increasing market integration of lower labour-cost jurisdictions in the South American hemisphere, and increased valuation of the Canadian dollar against the U.S. dollar ${ }^{289}$ The local impact of such closures have immediate and far-reaching effects in the form of job losses, local tax revenues and spending, government financial exposure through loans and other forms of strategic assistance and potential out-migration.

287 See Province of New Brunswick, Economic Development, Tourism and Culture, News Release, "Textıle Plant to Create 350 Jobs on Acadian Peninsula," February 23, 2000.

288 Court of Queen's Bench of New Brunswick, Trial Division, Judicial District of Saint John, Case No. S/M/92/2007.

289 In terms of the Province's financial exposure to this victim of an integrated global marketplace, "The government of New Brunsw1ck is probably going to take another bath on the plants. A big bath. According to Business New Brunswick spokesman Ryan Donaghy, besides the $\$ 37.5$ mullion written off in 2008 , the province still has a $\$ 12$ million debenture, a $\$ 2.5$-million promissory note, and a $\$ 1$ million loan in Atlantic Yarns. In Atlantic Fine Yarns, it has a \$640,000 loan and a \$23-million debenture. It will probably lose all of this money." Tim Jaques, "Buyer Being Sought Atlantic Yarn Closes," The Telegraph-Journal, January 21, 2009. 1. 
To facilitate tiansition of New Biunswick's economy away from the extraction of pitmary, 1esource-hased commodities and towards modern industries such as IT-enabled services (IT-ES), knowledge industries and advanced value-added manufacturing industries, the provincial government has explored opportunities in areas such as online learnıng, e-government, pharmaceutıcals, furniture, plastıcs, electıcal machınery, aircraft and technical instruments, ${ }^{290}$ all of which have international implications of relevance to this study.

\section{Background to the International Strategy}

New Brunswick's international policy sought to bring clarity to what it did on the world stage, what 1t wanted to happen in the future, and bring greater coordination to those efforts both internally and in relation to external partners. As a central policy coordinative minıstry reportıng to the Premier, the Department of Intergovernmental Affarrs played the lead role in developing the international "white paper" known as Prospering in a Global Economy: New Brunswick's International Strategy. A "white paper" can serve more than one purpose. Doerr suggests that white papers can have three roles. They can:

a) Inform and elicit debate, discussion and engagement among interested stakeholders; ${ }^{291}$

$290 \quad$ See Province of New Brunswick, Prosperity Plan, 2002

291 Also see Kim Richard Nossal, "The Democratization of Canadian Foresgn Policy," in Maxwell A. Cameron, Maureen Appel Molot, (eds.), Canada Among Nations 1995 Democracy and Foreign Policy, Ottawa: Carleton University Press, 1995: 29-43; and Mark Neufeld, "Democratızation in/of Canadıan Foreıgn Policy: Critıcal 
b) Facilitate public access to policy development piocesses and information; and

c) Help anticipate social problems and search for solutions before they arise.,292

The white paper has been used in the construction of Canadian foreign policy, a notable example being the Chrétien government's 1995 foreıgn policy white pape1 Canada in the World As an instrument of government, New Brunswick's own international white paper sought to communicate the government's desie to involve interested stakeholders from outside government ranks to participate in its development and implementation especially the federal government. On discussing the intergovernmental aspects of developing New Brunswick's International Strategy Bernard Lord noted,

In developing this International Strategy, I felt we needed to target the office of External Affarrs to educate our own federal government on our interests, so when Trade representatives are talkıng business in New York, they're thinking about what's possible in New Brunswick, not just Ontarıo or Québec. Sometımes when you go places, you realıze that there 1sn't a good understanding of New Brunswick out there- 1t's not malicious, it's just a fact. ${ }^{293}$

With respect to International Strategy's functional value, it was hoped that the policy would provide direction and guidance for routine activities pursued by the government. One IGA official involved in the International Strategy's development noted,

Reflections," Studies in Poltitical Economy, No. 58, Spring 1999: 97-119 for excellent contributions on the democratization of Canadian foreign policy.

292 Audrey Doerr, "The Role of White Papers," in Andrey Doerr and Peter Aucoin, (eds.), The Structures of Policy Making in Canada, Toronto- MacMillan, 1971: 197-200.

293 Interview, Bernard Lord, Premier of New Brunswick, June 8, 2007. 
I understand the value of having an International Strategy every time I leave the province When dealing with our federal and private sector pattness the strategy offers an opportunity for us to justrfy ou involvement, participation and pursuit of very specific objectives [ ] and, in a globalized world full of opportunities, give us a rationale to say 'no' to good ideas 294

Another official with the New Brunswick Community Colleges network of the Department of Training and Employment Development, also a keen supporter of the Province's International Strategy and the work of the ISWG pointed out,

After some twenty years in international development the NBCC needed to refocus such that its strategy would align with the province's economic development plan and export strategy The strategy bings together a number of departments and stakeholders and provides us with a platform for partnership, sharing of information and ideas and market intelligence Basically it gives us a distinct competitive advantage As a province we're able to provide clients (actual and potential) with an integrated solution to their challenges, a one-stop shop if you will The strategy also highlighted the urgency of working together in oider to compete with the rest of the world 295

In an effort to operationalize the International Strategy after its tabling in the Legislative Assembly, Minısters and (moie importantly) departmental Directors of Communication were asked to include overt mention of the International Strategy in news releases, speeches and other medium used to communicate with the public and other orders of government Ministers accepted this course of action as a way to link and rationalize the11 individual and departmental activities as supportive of the International Strategy as a means to reinforce departmental (as well as their own) relevance

\footnotetext{
294 Interview, Arnold Kearney, Director, FOLB, March 29, 2004

295 Interview with Maurice Roy, Director (New Brunswick Community Colleges), Department of Training and Employment Development, Fredencton May 11, 2004
} 
Questions atose fiom within the public service, however, as to whether 1egular and status quo activities not specifically recommended or initiated as a result of the Inteinational Strategy were simply being "1et1o-manufactured" into products of the International Strategy in order to magnify its importance and 1elevance For example, after the 1elease of the International Strategy Percy Mockler was named Minıster responsible for Inteigovernmental Relations and New Brunswick's relationship with La Francophone Mockeı was a very stıong and competent Minıstel, and in conversatıons indicated a genume willingness to ensure that activities undertaken within his ministerial purview were consistent and served the policy disection of the Lord government Upon signing a co-operation agreement with the President of the Conseil Général de la Vienne, René Monory, Mockle1 noted,

This agreement will also help to strengthen Franco-Canadian relations in accordance with Prospering in a Global Community New Brunswick's International Strategy [ . ] Once again, New Brunswick has a chance to demonstrate its leadership in working with our partners in the international Francophonie ${ }^{296}$

While theie is nothing incorrect about this statement, it does suggest that there is some relatıonship or linkage between New Brunswick and Le Département de la Vienne (the area in France from whe1e many Acadians originated) and the International Strategy In reality, the twinning agreement between the Province and la Vienne was concluded durıng the 1970-1987 Premıership of Richard Hatfield, and contınues to be a relatıonship of significance in the post-Loid adminıstration

296 Province of New Brunswick, News Release, "New Cooperation Agreement with Département de la Vienne, Fiance," November 13, 2003 
The expenience of diafting the International Strategy was itself intended to shape the processes of how international pironties were designed, not just the product Fol example, "turf" issues that existed between central agency and line departments had lesulted in a highly dysfunctional and generally uncooperatıve governmental environment in which intra-organizational collaboration was difficult and nearly 1mpossible in the 1ealm of international activities Many line departments viewed central agency efforts to corporatize international activities as thinly-verled attempt to intrude into areas of departmental mandate, and conversely, central agencres viewed line departmental adherence to their own parochial mandates as indicatıve of bureaucratic intransigence and non-cooperation. This dynamic is further discussed in Chapter 5 development thiough development of a contranan view respecting the professed "benefits" of corporate policy and "flattening" vertical hierarchies within government

The sense of need driving New Brunswick's development of this strategy related to mounting pressuies related to recent globalization In the lead up to the International Strategy and Prosperity Plan, one sector in which New Brunswick relied heavily on direct international involvement was the export promotion of goods and services As the Deputy Minister in charge of overseeing development of the International Strategy, Kershaw explains an early driver of the initiatıve hinged on promoting the province's economic interests, namely the promotion of trade. That said, he also viewed the province's small size as a positive factor in being able to coordinate efforts internally, as well as move towards the st1ategy's implementation, 
While New Brunswick was one of Canada's most trade dependent provinces, ${ }^{297}$ we lacked a corporate approach within government to international relations. New Brunswick fully recognized the federal government's jurisdiction in international relations, but knew we needed to do mote to promote and protect our international interests, so we moved to position New Brunswick accordingly.

We firmly believed that New Brunswick's relatively small size should be seen as a strategic asset as we could plan and execute an international strategy more effectively with our partness. When we conducted an inventory of our international travel within government, the range and scope of our global activities surprised a lot of people.

The keys to a corporate international strategy had to be focus, leveraging our assets, and working with our partners. Failure to execute any one of these three elements well, would spell farlure overall. ${ }^{298}$

New Brunsw1ck's reliance on international markets is evidenced by export performance ındicators spanning 1992 to 2002, in which Byrd and Généreux point out that despite weakenıng foreıgn markets for Canadian goods and services and an increased reliance on inter-provincial exports by provincial and territorial governments, New Brunswick was the only jurisdiction whose inter-provincial exports did not increase at a rate greater than its international exports.

In 2002, total exports accounted for $75 \%$ of New Brunswick's gross domestic product, the highest proportion among the provinces, up from $52 \%$ in 1992. New Brunswick's international exports increased at more than twice the pace of interprovincial exports between 2000 and 2002.

297 "New Brunswick has an export-dependent economy. We have always had to export to support our industrial base and to generate sufficient wealth to sustain our quality of life. In 2000, New Brunswick's international exports reached $\$ 7.6$ billion and exports to other provinces were $\$ 5.2$ billion. Together, international and inter-provincial exports of goods and services were equivalent to nearly $69 \%$ of our GDP, exceeded only by Ontario. We export around the globe to more than 100 countries spanning six contınents. More than 57,000 New Brunswickers' jobs flow from trade and exports." Province of New Brunsw1ck, Prosperity Plan, 2002 11.

298 Interview, John Kershaw, Deputy Minister, Education, 2004. 
Foreign sales rose at an annual average rate of $7.2 \%$, second only to Newfoundland and Labrador, compared with $2.9 \%$ for interprovincial sales. ${ }^{299}$

The following charts from Byrd and Généreux's research, which were current at the time of the International Strategy's development, demonstrate this reliance. ${ }^{300}$

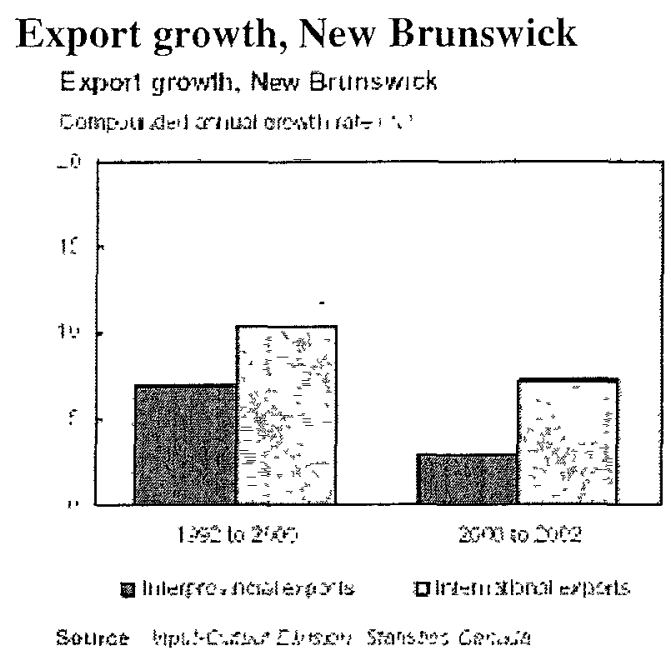

299 Craig Byrd and Pierre Généreux, "The Performance of Interprovincial and International Exports by Province and Territory Since 1992," Input-Output Division, Ottawa: Statistics Canada, 2004: 6.

300 Within the Province of New Brunswick's internationally-active departments and agencies it is widely noted that it is difficult, if not impossible, to accurately measure trade volumes for non-commodity based exports such as trade in services, knowledge industries and information technology. As a result, it is difficult to accurately gauge whether efforts to promote non-commodity-based exports have been successful. 


\section{Ratio of exports to GDP, New Brunswick}

Rotso of exports to GOP How Brutsonck

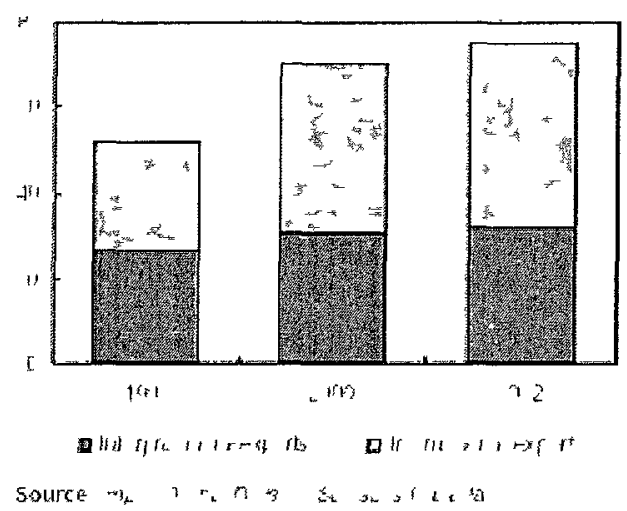

Whether this incieased tiending towards international exports is sustainable, however, has yet to be determined In 1esponse to the New Brunsw1ck government's goal of promoting self sufficiency announced 1 n 2006 by the recently-elected Liberal government of Shawn Graham, sevesal researchers from the University of New Brunswick's Economics department analysed the province's interprovincial and international exports as part of a larger examination of the policy By looking at the province's exports measured in chained ${ }^{301} 2002$ dollars Buckley, Cook and Subash observe that while New Brunswick's interprovincial exports remained farrly static from 1997 to 2002 , they gradually increase from 2002 to 2006 On the other hand, they note that from 1997 to 2000 the increase in New Biunswick's international exports 1s significant, aveiaging a $\$ 500$ million increase pei year with a $\$ 12$ billion increase from $20002001,{ }^{302}$ a jump attributed to major increases in global commodity prices This trend

301 Measured in reference to the real purchasing power of 2002 dollars

302 One of the challenges endemic to being a small province relates to the strong correlation between measuring piovincial economic performance and the performance of individual companies For example, while New Brunswick's international exports sharply in 2000-2001, much of this can be atti1buted to the $\$ 1$ billion upgrade to the Irving O1l 
continued to 2004, at which time incieases in New Brunswick's international exports plateaus and drops sharply in 2006 on account to "a decline in the export of a number of agnicultural and fishing products, which represent a somewhat significant portion of the province's foreign exports.",303

Although the Government of Canada has a fiduciary iesponsibility to work in the interest of all Canadians, it does not have the mandate to champion the interests of any one province to the exclusion of others, and the New Brunswick government felt it must be more assertive at protecting and promoting 1ts own interests to avord socio-economic destitution. A measure of that "self help" includes identifying international interests, communicating those interests with the right stakeholders, and having the discipline to commit resources to pursue those interests in a corporate and coordinated manner- a rational process, but one that would ultimately reveal cracks in its development process and implementation.

Company refinery in Saint John in 2000 which doubled its production capacity. See Sector Report on Petroleum Products, 1999/2000 Annual Report, Office of Energy Efficiency, Natural Resources Canada, http://oee.nrcan.gc.ca/Publications/nfosource/Pub/c1pec/annual_report99-00, Accessed: October 30, 2009.

303 See M Buckley, P. Cook and P. Subash, "Trade Indicators," in M. Anthony Tremblay, Michael Boudreau, Peter Toner, (eds), Exploring the Dimensions of SelfSufficiency for New Brunswick, NBASRDC, 2009. 


\section{New Brunswick's International Strategy}

In the interest of delving deeper into the New Brunswick's International Strategy, policies and practices, the following pages overview

a) Provincial and federal actors significant to the development and articulation of New Brunswick's Internatıonal Strategy;

b) Basic facts concerning New Brunswick's International Strategy; and

c) Strategic considerations underpinning the policy development process as well as internal-to-government and external stakeholder dynamics that merit consideration.

First, we will look at the three main provincial and federal actors significant to the development and articulation of New Brunswick's International Strategy Intergovernmental Affarrs (IGA), Business New Brunswick (BNB), and the Department of Foreign Affairs and International Trade (DFAIT).

Intergovernmental Affairs

The lead provincial department with respect to New Brunswick's International Strategy is (at time of writing) the Department of Intergovernmental Affars (IGA), previously named the Department of Intergovernmental and International Relations (DIIR), which 
prior to 2003 was also called IGA ${ }^{304}$ The department's strategic mandate involves "maximizing the impact of New Brunswick's intergovernmental and international 1elations [and working] with other departments to ensure a corporate and stiategic approach to relationships with other governments, communities and organizations "305 Notwithstanding peirodic reorganizations, IGA is roughly divided into thiee divisions Federal-Provincial Relations (which handles issues pertaining federal-piovincial ielations and relations within the NAFTA), Fiancophonie and International Affarrs, and Trade Policy While it might be expected that IGA would have retained close and collegial relatıons w1th DFAIT prior to the development of the International Stiategy as a regular aspect of its departmental mandate, it had (1n reality) little such contact. Upon arriving at the Pearson Bulding in Ottawa to initiate formal discussions with the DFAIT with respect to New Brunswick's International Strategy and on behalf of IGA, one official from the Federal-Provincial-Territorial quipped, "Welcome to Foreign Affairs, where have you been?"

From an intra-organizational perspective, the lack of coordination with respect to New Brunswick's international relations was surprising for a province as small and interconnected as it is (in light of Kershaw's earlier statement regarding the benefits of

304 Bill 55, An Act to Amend the Executive Councll Act, Legislative Assembly of New Brunswick, Province of New Brunsw1ck, April 2003 The Department was subsequently "re-renamed" Intergovernmental Affarrs.

305 New Brunswick Department of Intergovernmental Affarrs, Annual Report 20062007 1. The mandate of the International Relations and Francophonie Division is noted on $\mathrm{pp}$ 16-17 to include a) maximizing benefits from cooperative agreements and arrangements with Canadian and foreign governments; b) coordinating and assurnng maximum economic, social and cultural benefits for the piovince's participation in international and intergovernmental organizations; c) negotiating and implementing F/P agreements relatıve to official languages; d) coordinating implementation of New Brunswick's International Strategy, and d) coordination of diplomatic visits. 
New Brunswick's small size) To addıess chronic internal organızatıonal disjointedness, in mid 2002 to eatly 2003 IGA $^{306}$ initiated an inter-departmental International Stiategy Working Gioup (ISWG), co chaned the development of the Inteinatıonal Strategy with Business New Biunswick (BNB) and began developing the Strategy through internal and external consultations with government, puvate sector, the federal government, CSOs and academic institutions

Bustness New Brunswick

As the economic development arm of the Government of New Brunswick, the Department of Business New Brunswick is responsible for the promotion and pursuit of inbound investment and immigration, outbound exportation of goods and services and support of businesses already located within the province Some of BNB's international responsibilities include identification of trade opportunities, development of infrastructure and networks in fore1gn markets, co-ordination and participation in strategic trade shows, international dissemination of New Brunswick's economic climate for the purpose of stimulating inwards business investment and location, and promotion of business stream or skilled laboul immigration ${ }^{307}$ The following pages provide

\footnotetext{
306 While cooperative federalısm inherently suboidinates the "power, status, and prestige of individual governments to piogiammatic objectives, executive federalism does exactly the opposite" by concentratıng deteimination of broad governmental policy in to the hands of a small intergovernmental cadie, an interesting point made by Stevenson in Fox, White, 1991127 It is in this world that IGA is particularly relevant, and effective

307 Through the Provincial Nominee Piogram (PNP) Agieement, a joint initiative between the Government of Canada and the Province was signed in February 1999
} 
additional information on BNB's status as one of the Province's most important internationally active departments

As the lead government department responsible for advancing the piovince's economic development objectives, BNB works with various provincial departments and organizations such as IGA (where government-to-government relations ate involved), Tiaınıng and Employment Development (skills development and training), the Regional Development Corporation (RDC) (special fundıng programs for targeted economic development, for example in the north), the Population Growth Sectetariat (PGS) (worker v1sas and permits); and others as required such as Environment, Local Government and Fisheries.

BNB also works in conjunction with other federal organizations such as the Atlantic Canada Opportunities Agency (ACOA), DFAIT, Industry Canada, and C1t1zenship and Immigration Canada (CIC) on an as required basis, as well as non-governmental partners that are arm's length from government, such as the National Research Counc1l (NRC) and Research and Productıvity Counc1l (RPC), and external-to-government, such as the Unıversity of New Brunswick, Unıversité de Moncton, New Brunswick Community Colleges and a wide range of business promotion organizations such as the Enterprise Network, Conse1l Economique and Canadian Manufactu1ers and Exporters Associatıon (CMEA). 
BNB's core lines of business at the time of the International Strategy's development relate strongly to the investment attraction function ${ }^{308}$, and are contained in the 2002-3 Annual Report:

Two key thrusts BNB are to ensure that business develops in New Brunswick and that new investment is attracted to New Brunswick. Business development activities traditionally involve the success of current in-province companies while investment opportunities are targeted towards out-of-province or external jurisdictions. ${ }^{309}$

Business New Brunswick's formal mandate at the time of the International Strategy's implementation is as follows,

As the lead department in economic development, Business New Brunswick (BNB) focuses its efforts on the stimulation of economic prosperity and global competitiveness through the development and support of opportunities for growth, innovation and exports in all regions of the Province. ${ }^{310}$

Despite having intensive relationships with governmental and non-governmental partners involved in the execution of its trade and investment promotion mandate, and despite its formally assigned responsibility for advancing the objective of economic development, $\mathrm{BNB}$ is oftentimes the target of internal provincial government criticism. During the

308 Given concern over a lack of lack of sustainable and well-paying employment, job creation announcements resulting from new investments, strategic partnerships or alliances tend to receive the lion's share of political and media attention in New Brunswick as compared to promotion of trade partnerships.

309 Business New Brunswick, Annual Report 2002-2003, p. 6.

310 Business New Brunswick, Annual Report 2003-2004 p. 7. Interestingly, not a single mention of New Brunswick's International Strategy is made in this 35 page document. 
development of the International Strategy for example ${ }^{311}$, BNB was frequently accused of puisuing its mandate in a highly isolated, silo-style manner, oftentimes impervious or unconcerned with corporate policy architectuies and frameworks

Howeve1, BNB officials are quick to point out imposition of a corporate economic development strategy onto the department without accompanying budgetary resources required for the11 implementation causes policy and operational difficulty ${ }^{312}$ In the case of several action priorities contained in the International Strategy, such as the convening of an International Business Symposium, BNB expressed concern that the while the department was expected to play a lead role in its implementation, it was nether the ISWG member that contributed the 1dea, nor was in a position to fund the initiative on a unilateral basis given the fact that the International Strategy lacked approval of operational financing from Cabinet.

311 Durng deliberations of the International Strategy Working Group, 2002, several former working group members (under condition of absolute anonymity) noted that they questioned the extent to which BNB was willing align its departmental strategic plan to align with corporate prionities

312 Having worked as an architect of New Brunswick's International Strategy at Intergovernmental Affairs and investment officer with the investment attraction division of Business New Brunswick, it is appears to me that whlle central agencies may take on the challenge of developing corporate strategy orientations, such as the International Strategy with gusto, they sometimes fall to incorporate within their framework adequate flexibility to include areas of activity that are core to line departments' mandate execution requirements despite their claim to have engaged in internal and external stakeholder consultations. As noted in the previous Chapter, incongruence between departmental interests and corporate direction can result in dramatic gaps between desired outcomes, actual outcomes, and method of policy implementation. The Province's commitment to host an International Business Symposium (discussed in Chapter 3 as part of the New Brunswick International Day in Ottawa) is one such example. 


\section{Foreign Affairs and International Trade}

The Department of Foreign Affairs and International Trade (DFAIT) is the lead federal department responsible for the development and articulation of Canada's foreign policy. Its Federal-Provincial-Territorial (CFP) Division is responsible for communicating with regional governments. Although de facto federal jurisdiction over a wide range of policy areas since Confederation has diminished since the 1930s, the domestication of Canadian foreign policy and the internationalization of areas of provincial jurisdiction, ${ }^{313}$ places DFAIT in the position of having to balance the need for a singular Canadian voice on the world stage while placating provincial aspirations in areas of their own constitutionallyentrenched jurisdiction. Cursory overview of DFAIT's annual reports around the time of New Brunswick's International Strategy activities reflects growing attention. While in 2001-2 the Business Line of DFAIT's Public Diplomacy Fund there was but a scant mention of interest "to manage the international dimension of F/P/T relations,"314 the 2002-3 Estimates go on to note that,

Foreign and domestic policies can no longer be regarded as distinct or separate aspects of the government's operations. The two are now interconnected and interdependent in a way that this country has never seen before, a reflection of the highly integrated, globalized environment in which Canadians live and work. ${ }^{315}$

313 See Denis Stairs, "Public Opinion and External Affairs: Reflections on the Domestication of Canadian Foreign Policy," International Journal, Vol. 33, Winter 1978. 314 DFAIT, Estimates, Part III, Report on Plans and Priorities, Ottawa: Canadian Government Publishing, 2001: 32.

315 Further, "Working with the other federal partners, the Department will continue to consult with the provinces and territories on a wide range of files [...] It will also provide support for public diplomacy activities of the provinces and territories and establish a framework, based on current practices, to guide interaction between the two levels of 
The 2003-4 Estimates ${ }^{316}$ continue to suggest an inciemental fortification of the federal government's facilitation of provincial international activities In advocating for gieater integration of foreign and domestic policies, it is noted,

Coordination on policy planning will be increased with other federal departments and agencies as well as the provinces and teritories. This will ensure greater integration of foreign and domestic policies, fuller engagement of the provinces and territories in foreign policy, and consistency of federal laws and regulations with Canada's international obligations 317

The 2003-4 DFAIT Estımates also signal a departmental w1llingness to collaborate with other federal patners to ensure that the government's international interests are more integrated, strategic and better cooldinated across both levels of government "The steps the Department is taking to increase its collaboration with government partners involved in international affairs will ensure greater policy coherence." 318 Furthermore,

In enhancing its partnerships with the provinces and territories, the Department will provide support for greater integration of federal, provincial and terntonal policies related to international affairs. This process will help reinforce a climate of trust and dependency. It will also

government on international affairs, ensuring a single, coherent foreign policy for Canada." 315 "The Department is actively supporting those provinces with an interest in establishing or expanding their international presence." DFAIT, Estımates, Part III, Report on Plans and Prorities, Ottawa. Canadian Government Publishing, 2002: 11

316 2003-4 statistics are being used, rather than the most recent and ava1lable figures, in order to provide context related to the time during which the International Strategy was being developed and implemented

317 DFAIT, Estımates, Part III, Report on Plans and Pronties, Ottawa: Canadian Government Publıshing, 2003. 19.

318 DFAIT, Estumates, Part III, Report on Plans and Priorttıes, Ottawa Canadian Government Publishing, 2003: 52. 
better enable other levels of government to play a role in fostering Canadian interests internationally $[\ldots]^{319}$

While from a provincial perspective it is tempting to view DFAIT's treatment of the provinces in terms of Savoie's 2001 characterization of a federal government content on keeping New Brunswick in a position of economic dependency and supplication, cooperative federalism advocates ${ }^{320}$ would maintain that DFAIT appears to be open to working with New Brunswick. For example, in a joint letter issued to the then DIIR Deputy Minister the Deputy Ministers for International Trade and Foreign Affairs observed that,

Following the unveiling of New Brunswick's International Strategy in June 2003 and subsequent discussions between the Department of Foreign Affairs and International Trade and the New Brunswick Department of Intergovernmental and International Relations, we have the pleasure to invite your province to join the Department of Foreign Affairs and International Trade in partnership to hold a New Brunswick International Day in Ottawa. ${ }^{321}$

319 DFAIT, Estimates, Part III, Report on Plans and Priorities, Ottawa: Canadian Government Publishing, 2003: 54.

320 "Under cooperative federalism, the constitutional division of powers was preserved but federal and provincial ministers and public servants engaged in consultation and coordination to reach joint decisions on policies and programs of mutual concern." Kernaghan, Siegel, Public Administration in Canada, 1991: 419. Also see Smiley, Watts, 1985; Stevenson, 1989.

321 DFAIT, Letter to Deputy Minister of Intergovernmental and International Relations (PNB) from Deputy Ministers of International Trade and Foreign Affairs, (acquired through written request to IGA), September 30, 2003. The letter continued, "By forging closer working relationships and facilitating dialogue, the New Brunswick International Day in Ottawa has the potential to benefit both the federal government and the Province of New Brunswick. From the federal perspective, we welcome the opportunity to gain further insights into New Brunswick's International Strategy, as well as the province's interests and perspectives. We also look forward to presenting our priorities, programs and services. The New Brunswick International Day should encourage fruitful discussion and the occasion to examine possible synergies and areas for collaboration." 
While the goal of this International Day in Ottawa was to showcase New Brunswick's International Strategy to relevant DFAIT officials and interested parties within the international affarrs community in Ottawa, its true significance was related to the willingness of the federal government to expend human and financial resources, not to mention political capital, to do so. To that point, no province espousing a formal international strategy had received DFAIT's assistance in rolling it out to the bureaucratic and diplomatic community, and the event was lauded as a significant milestone in the way the federal and provincial governments could work together in this polıcy domain.

DFAIT's regional office for the Atlantic Canada region is located in Moncton, New Brunswick and headed by a STC/Regional Executive Director, who ensures that New Brunswick is the recipient of information on an as needed basis. The working relationship between this regional office and BNB is highly integrated, with representatives from both organizations (for trade and investment 1ssues) frequently sitting shoulder-to-shoulder at the same events.

While the Moncton office of DFAIT works in close collaboration with BNB and IGA on 1ssues related to trade and investment promotion opportunities and methods, some 1ssues suggest the flow of information from the federal government (at the Ottawa level) to the Province is less-than-complete and dogged by chronic federal paranoia of providing full disclosure to the provinces on strategic market intelligence For example, as part of Canada's efforts to raise its share of inbound FDI, the federal government developed and 
administers a database ieplete with information identifying companies with a high likelihood to engage in international expansions. That information, howeves, is not routınely shared with provincial governments, even where there is a neat fit between the company identified and the economic pros and cons of the province. As one federal official openly observed in a F/P/T trainıng environment, "we don't slip information sideways," 322 meaning that in their view, federal information and analysis shared with the provinces was seen as leaking information outside of an envelope of intergovernmental trust.

In other cases, anecdotal ${ }^{323}$ information provided by several New Brunswick government officials noted that they suspected that not all New Brunswick-relevant trade and investment leads had entered into the formal information-sharıng channel noted above. It was their contention that sometımes informal communications channels between Canada's foreign officers and locally-engaged staff and the provinces took on a preferential and off-the-record character which involved: "one-off" communication of market opportunities to specific individuals who had "worked" the post; favouritısm of large provinces such as Ontario and Quebec; and a lack of confidence that bona fide leads could be serviced by small provinces like New Brunswick, thus leading to damage to the Canadian brand.

322 Anonymous DFAIT official, Ottawa, July 2008.

323 None of the officials at BNB with whom I discussed this matter were willing to state as such on the record for fear of damaging relations with their federal colleagues and reprisals from their provincial employers. 
With this overview of the main institutional playeis involved in New Brunswick's international activitics, let us take a closer look at the actual Intcrnational Strategy.

\section{Prospering in a Global Community: New Brunswick's International Strategy}

New Brunswick's Internatıonal Strategy ${ }^{324}$ identıfied New Brunswick's key internatıonal interests and formally communicated them to internal-to-government and external stakeholders. ${ }^{325}$ The Strategy was released in the Legislative Assembly of New Brunswick on April 1, 2003 and was accompanied by the tabling of Bill 55, An Act to Amend the Executive Council Act, whıch highlighted IGA's new internatıonal mandate 326 The IGA news release cited Lord's comment that the International Strategy was "designed to help achieve the province's prosperity targets and is aimed at harnessing our competitive strengths by promoting a focused and coordinated approach to our international activities." 327

After the International Strategy's release, the Deputy Minister of IGA observed that the value of a formal international strategy for New Brunswick lay in its functional and symbolic value and how it helps establish "objectives and targets for the province and designates specific markets for attention." The International Strategy was intended to improve the internal management of the Province's international activities through

\section{${ }^{324}$}

325

326.

New Brunswick Acts 2003. 327 Province of New Brunswick, Prospering in a Global Communtty: New Brunswick's International Strategy, New Brunswick, 2003· 6.

Formal title.

I.e. "Internal" and "external" to the provincial government

Also see Subsection 2 (1,3), Executive Council Act, Assented April 11, 2003, 
promotion of enhanced intra organizational harmonization and policy integiation "The strategy requires depatments to work more closely together in a formal approach to maxımıze var1ous 1esources being applied to talget markets "328

Schematically, the International Strategy was compised of elements dealing with Guiding Pınciples, Stakeholder Relatıons, Success Factors, Return on Investment Ciıte11a, Strategic Elements, and Designated Target Markets Addıtıonal information on these elements is avarlable in the Table below These broad elements led to 58 specific action prionties developed through hoizontal consultations across the provincial government as well as meetings with provincial stakeholde1s outside government as well as with federal officials in Ottawa

\begin{tabular}{|c|c|}
\hline \multirow{2}{*}{\multicolumn{2}{|c|}{ Major Components of New Brunswick's International Strategy }} \\
\hline & \\
\hline $\begin{array}{l}\text { Guiding } \\
\text { Principles }\end{array}$ & $\begin{array}{l}\text { Outhines core principles of the International Strategy, including the } \\
\text { Province's official bilingualism, support of a federal role in } \\
\text { international relations, and search for prosperity for its residents }\end{array}$ \\
\hline $\begin{array}{l}\text { Stak } \\
\text { Rela }\end{array}$ & $\begin{array}{l}\text { Key partners with whom interests in strategic activities will be } \\
\text { pursued, including the federal government, private sector businesses } \\
\text { and commercial ventules, academia, and civil society at large }\end{array}$ \\
\hline $\begin{array}{l}\text { Success } \\
\text { Factor }\end{array}$ & $\begin{array}{l}\text { Fostering a corporate approach to international activities, and } \\
\text { strengthening collaborative federalism international affairs }\end{array}$ \\
\hline $\begin{array}{l}\text { Return on } \\
\text { Investment } \\
\text { Cruteria }\end{array}$ & $\begin{array}{l}\text { Economic (incieased trade, market diversification, immigration, } \\
\text { international development and innovation), Financial (bioader investor } \\
\text { base), Social (higher standard of living, foreign student enrolment, } \\
\text { skilled professionals, global fieedoms), and Environmental (enhanced } \\
\text { piovincial involvement in global envilonmental renewal and } \\
\text { sustainable development piomotion) }\end{array}$ \\
\hline Strategic & Investment and trade targets puisuant to the Prosperity Plan, \\
\hline
\end{tabular}

328 Interview, Jim McKay, Deputy Minister, IGA, May 11, 2004

329 See Province of New Brunswick, International Strategy, 2003 


\begin{tabular}{|l|l|}
\hline Elements & $\begin{array}{l}\text { increasing inbound provincial immigration and services; building a } \\
\text { culture of innovation and education; participation in international } \\
\text { development activities; leveraging the province's reputation as a } \\
\text { resource-based economy; cultivation of a coherent and effective } \\
\text { worldwide image and reputation; and promotion of international } \\
\text { competencies. }\end{array}$ \\
\hline $\begin{array}{l}\text { Designated } \\
\text { Target } \\
\text { Markets }\end{array}$ & $\begin{array}{l}\text { Consultative policy development revealed corporate interests in } \\
\text { markets such as the United States; La Francophonie; Asia (with } \\
\text { emphasis on Japan and China); the United Kingdom; Germany; } \\
\text { Mexico; and Eastern Europe. }\end{array}$ \\
\hline
\end{tabular}

While some of the action priorities were initially viewed to restate existing areas in which the Province was internationally active, IGA hoped that the white paper's theoretical value would be seen by its provincial government counterparts and the general public, and that the formal organization and communication of those activities would somehow clarify New Brunswick's international interests.

At the outset of the International Strategy development process, the Province saw its small size and perceived ability to organize quickly and efficiently to compete on the international stage as a competitive advantage.

New Brunswick's small size can be a tremendous advantage in a competitive world in which speed and collaboration matters. We need to coordinate the efforts of governments, business, labour, communities, universities and other learning and research institutions in a new competitive alliance to build the critical mass that comes from having all partners across the province share a common vision and move with a united purpose toward our clear goals and focused priorities. Greater Opportunity sets out the strategic partnerships we need to achieve prosperity. ${ }^{330}$

330 Province of New Brunswick, Prosperity Plan, 2002: 6. 
This small size factor would prove not to be the advantage orginally envisaged, a point elaborated in Chapter 5. The following sections examine strategic factors associated with the International Strategy fiom the perspective of external interests (that relate to New Brunswick's relationships with actors outsıde its own governmental eco-system in the world), and internal interests (that relate to its relationships with actors within its own bureaucrat1c structure)

External Strategic Interests

The International Strategy was based on calculations regardıng its impact on strategic relations with external stakeholders such as the federal government, and the rmage New Brunswick wanted to project. Some of these external strategic interests were official and related to realızıng the policy goals of the Internatıonal Strategy. Others were unofficial, and related to enhancing relations with the federal government while simultaneously buildng its own capacity to be an effective international actor. The following pages look at each, before moving to a discussion of some of the internal strategic interests that were also at play.

One of the two official interests of the Internatıonal Strategy was to reinforce the notıon that the federal government had pre-emınent jurısdiction ${ }^{331}$ over Canada's international

331 This is to say, although regional governments share jurisdiction over international policy, the Government of New Brunswick appeared to assign jurisdictional primacy over international affarrs to the federal government rather than insist on the existence of jurisdictional equivalence. For example, despite New Brunswick's parochial interests in dealıng in the American marketplace, at a conference in Calgary in 2002 Bernard Lord stated, "There should be one overriding interest that governs our relationship with the 
1elations policies Notwithstanding the legitimate claim that regional governments within the Canadian federation have the right to paricipate in international affaris as actors in areas of constitutionally-established juisdiction, essentially an expiession of the province-bulding spint of the 1960s, the Province respected the federal role in 1epresentıng Canada's views abrodd, and did not echo views such as Québec's that piovinces were entitled to paradiplomatic primacy in a1eas within thei1 jurisdiction The International Stiategy notes, "We tecognize and suppoit Canada's constitutional role in international relations "332 This point requises some elaboration

It seems curious that while much of the scholarly literatuie mentioned in the previous Chapter establishes that central level governments are not untary actors on the world stage, and that constitutionally-assigned areas of provincial jurisdiction cannot be intruded upon by the federal government through projecting that policy area onto the world stage, New Brunsw1ck appeared to profess at length and unequivocally the federal government's jurisdiction in international affairs

The federal government exercises jurisdiction over Canada's international affarrs, treaty ratification, and tiade policy, and shares jurisdiction with the provinces on immigration The Government of Canada offers significant international services within Canada and throughout the world New Brunswick's success in the global community is inherently tied to Canada's success on the international stage We welcome and embrace Canada's enviable international image and will alıgn ourselves closely with the Government of Canada's foreign policy outlook 333

United States - Canada's There should be one motivation that guides us - Canada's There should be one vorce that speaks - Canada's" Speech Delivered by the Honourable Bernard Lord, Premier of New Biunswick, Borderlines Conference, Calgary, Alberta, Septembe1 13, 2002

332 Province of New Brunswick, International Strategy, 20036

333 Province of New Biunswick, International Strategy, 20039 
Even Bernatd Lord expressed the view that the feder al government should enjoy a degree of freedom in representing what Canada was on the world stage He noted,

I support the view that in forergn policy, these should be only one vorce on the world stage-Canada's It is not the provinces' place to challenge that role On socral and economic issues, however, provinces have juisdiction, and Canada must work with provinces to ensure a common and unified vorce is hear d on that world stage ${ }^{334}$

On account of Lord's preference for smooth interaction with the federal government, DFAIT participation in the strategy-bulldng phase included representation from the Federal-Provincial-Territorial (F/P/T) unit Keishaw observed, "We approached the federal department of Foreign Affarrs and International Trade for assistance in both the planning and execution of our plan, and the positive response we received from their officials was overwhelming " 335 This conciliatory approach stands in contrast to the more confrontational, challenging approach of other provinces Québec, for example, tends to deemphasize federal jurisdiction in international affairs in favou of adherence to its Gérnn-Lajoie doctrine which emphasizes that province's autonomy in international affairs To illustrate the point, at the 2004 White Paper conference referred to in the last chapter, the repiesentatıve from Québec's International Affarrs Minıstry noted in a panel discussion on provincial international affairs that the province's international prionties sometımes have "friction" with those of the federal government, and in instances where federal and piovincial interests intersect, "Québec's interests must take precedence "336

\footnotetext{
334 Interview, Bernaid Lord, Premier of New Biunswick, June 8, 2007

335 Inter view, John Kershaw, Deputy Minister, Education, 2004

336 Fiom conference proceedings, White Papers Foreign Policy Management Tools?, Québec City, May 2004
} 
The second official external objective of New Brunswick's International Strategy was to rcorient the Province's pursuit of intcrnational intcrests outside the United States, and capitalize on its English-French character by exploiting its membership to La Francophonle Concerning international trade, for example, the International Stiategy noted,

New Brunswick's special status in La Francophonie offers a strategic gateway to the member countries A new corporate action plan is currently being developed to fully engage all provincial departments and ou international partners in pursuing our trade, investment, 1mmigration and cultural interest in the most effective and efficient manner [..] the Province of New Brunswick will also pursue our specific immigration, investment and trade interests with the most promising member states, with special emphasis on France. ${ }^{337}$

On this point, the following table demonstrates that in the five years leading up to the development and implementation of the International Strategy, a little more than $89 \%$ of New Brunswick's international exports headed to the United States.

\begin{tabular}{|l|l|l|l|}
\hline \multicolumn{2}{|c|}{ Destination of New Brunswick's International Exports (\%) } \\
\hline & \multicolumn{1}{|c|}{1998} & \multicolumn{1}{c|}{2000} & \multicolumn{1}{c|}{ Table 902 } \\
\hline United States & 81.1 & 86.7 & 89.2 \\
\hline Japan & 3.6 & 3.1 & 2.4 \\
\hline United Kingdom & 1.1 & 1.3 & 1.42 \\
\hline Belgium & 1 & .85 & .71 \\
\hline Braz1 & 31 & .10 & .67 \\
\hline Germany & 1.4 & 11 & .65 \\
\hline
\end{tabular}




\begin{tabular}{|l|l|l|l|}
\hline Spain & .95 & .41 & .38 \\
\hline South Korea & .13 & 33 & 38 \\
\hline India & 11 & .08 & .34 \\
\hline $\begin{array}{l}\text { Dominican } \\
\text { Republic }\end{array}$ & .47 & .25 & 34 \\
\hline Otheis & 7.1 & 4.82 & 35 \\
\hline
\end{tabular}

In the five years following the International Strategy from 2003-2007, howeve1, approximately $88 \%$ of New Brunswick's total exports contınued to go to the United States. While Chapter 5 provides more substantıve analysis of the Province's stated International Strategy objectives and the actual results, the following table demonstrates that New Brunswick's attempt to deal with economic over-reliance on the U.S. and diversify its international export markets had mixed results

\begin{tabular}{|c|c|c|c|}
\hline \multicolumn{4}{|c|}{$\begin{array}{c}\text { Table } 10^{339} \\
\text { Destination of New Brunswick's International Exports (\$/thousands) }\end{array}$} \\
\hline & 2003 & 2005 & 2007 \\
\hline United States & 88.9 & 90.5 & 88 \\
\hline Belgium & .45 & .64 & 1.02 \\
\hline United Kingdom & 1.18 & .67 & .74 \\
\hline Span & .49 & .18 & .73 \\
\hline Japan & 1.72 & .83 & .61 \\
\hline Brazıl & .55 & .50 & .61 \\
\hline India & .65 & .46 & .58 \\
\hline Netherlands & .13 & .76 & .47 \\
\hline Romanıa & .16 & .07 & 44 \\
\hline China & .50 & .19 & .43 \\
\hline Others & 5.28 & 5.18 & 6.34 \\
\hline
\end{tabular}


Looking at some of the more implicit, objectives of the International Strategy, one of the Piovince's goals was to buld up its capacity as an international actor in its own i1ght, in part, to mitigate the unaddiessed federal encroachment into ateas deemed to be within provincial juisdiction, particularly those associated with economic development and the education field While this may be seen as contradictory to the goal of engendesing gieater cooperation with the fedetal government, theie is a fine line between promoting collaboration and federal policy pımacy and surrendering juıısdiction in areas that fall clearly within the provincral interest-set In this way, although New Brunswick saw the International Strategy as a policy area with which to build partnership, it also demonstrated an unwillingness to surrender its own prerogative to act in certain policy ateas

The second, unofficial external strategic interest of the Province derives from comments made by varıous Deputy Ministers and other officials who note that New Brunswick developed its International Strategy in a way that facilitated its synchronicity with federal international polıcies As the old sayıng goes, "the squeaky wheel gets the grease," and certain officials argued that the inherent value in the International Strategy lay in its ability to catalyze federal recognition of the province's international activities At about the same time as New Biunswick was developing 1ts International Strategy, the federal government through the Department of Foreign Affarrs was looking to update its own foreign policy piospectus, which had not been placed under substantive scrutiny since Canada and the World had been released by the Liberal government in $1995^{340}$ The Dialogue on Foreıgn Polıcy was publıcly intıated by DFAIT Mınıste Bıll Graham as a $340 \quad$ DFAIT, Canada and the World, Ottawa, 1995 
discussion ("gieen") paper which sought to update Canada's position on a wide variety of issues of foreign policy significance, followed by a final report summanzing the major streams of public input received over the public engagement peirod ${ }^{341}$

While much of the final report's findings were based on populat consultations "conducted through country-wide Town Hall meetings, written submissions from individuals and organizatıons, expert roundtables and electronic submissions on the Dialogue Internet site, ${ }^{342}$ the New Brunswick government requested and was extended the opportunity to address DFAIT representatives from the F/P/T Division on a bilateral basis on 1ssues of significance to the Province The request resulted in a delegation from DFAIT going to Fredericton during the consultation period at which time the Province used its International Strategy as the basis with which to request federal assistance in core areas of activity.

Despite Deputy Minısters' expectation that the report released by DFAIT Minister Graham would acknowledge the fundamentally important role played by the provinces in the artıculation of the Canada's foreıgn policy given the internationalization of areas within provincial jurisdiction, the report mentioned the word "province" twice. The first occurrence made a balanced and jurisdictionally-sensitive observation that,

Comments from provinces and territories urge closer consultation with the federal government on bilateral as well as multilateral trade files and

341 DFAIT, A Dialogue on Foreign Polıcy, Ottawa, January 22, 2003, DFAIT, A Dialogue on Foreign Policy: Report to Canadians, Ottawa, May 1, 2003.

342 DFAIT, Press Release, "Graham Reports on Foreign Policy Advice from Canadian Public," Ottawa, June 27, 2003. 
negotrations, especially as these increasingly bear on areas of piovincial juisdiction such as envilonment, education and health ${ }^{343}$

The second mention of the word "province" offered by a dialogue participant (and selected for publication by DFAIT), however, was less laudatory of provincial efforts to puisue international aspects of the11 constitutionally assigned areas of competence,

We need to define the "Canadian advantage" Canada must overcome the current fiagmentation of messages and activities, with different federal departments and provinces making their own global sales pitches and puisuing uncoordinated policies It is especially ronic that in an era of international interdependence, so many of our domestic initiatives are pursued in isolation from each other ${ }^{344}$

The significance of this diminished presence of the provinces in DFAIT's report suggests that the International Strategy did not have a substantial effect, and that Ottawa was not about to accord to the provinces a heightened stature in terms of the realignment of Canada's foreign policy outlook

Internal Strategıc Interests

The International Strategy also had important internal implications, in that it appeated to be part of an overall effort to centralize power within the Premier's Office, Intergovernmental Affarrs and the Executive Counc1l Office (which served Cabinet in an administrative capacity) thiough the introduction of policy initiatives requiring 343 DFAIT, A Dialogue on Foreign Policy, Ottawa, Januar y 22, 200315

344 Dialogue participant, DFAIT, A Dialogue on Foreign Pollcy Report to Canadıans, Ottawa, May 1, 200319 
corporatısm, and ergo, heavy central agency mobilization. Based on this assertion, we can see that IGA used the Internatıonal Strategy to stiengthen how central agency and line departments defined and pursued theis international objectives in ways consistent with highly centralized interests To ensure that inter and intra-departmental activities were consistent with the International Strategy a number of internal-to-government policy measures and mechanısms were implemented, such as introduction of an Internal Travel Advisory (ITA) and centralized approval procedures requred for government departments and agencies to become signatory to international agreements, that will later be discussed in greater deta1l. Before moving forward, a few words should be said with respect to this drive towards centralızation of polıcy within the New Brunswick government

The drive to centralization in the name of policy efficacy was seen largely as a movement initiated from within the Office of the Premier upon Lord's election as Premier in 1999. The implications for IGA and ECO were considerable given that both ministries were part of the Premier's own portfolio, and were physically located on the same floor in the same bulding as the Premier's Office. Moreover, by convention New Brunswick's international actıvities were largely determined and pursued by Premiers. Former Secretary to Cabinet Kevin Malone notes, "Traditionally, in New Brunswick, the Premiers have had a direct influence on how internatıonal matters are pursued. And since each Premier is different, each one personalized the file to sult their preferences." He contınues, "Each of the four elected Premiers of recent memory (Robichaud, Hatfield, McKenna and Lord) has put therr stamp on New Brunswick's international affarrs in a 
unique and highly personal way" 345 Admittedly a stiong believer in the value of policy as a determinant of government action, ${ }^{346}$ Lord invested considerable political attention 1nto developing interconnected policy fiameworks that ieinforced administrative centralization This policy centralization (some would say "stıffenıng") was most evident in the 11gidity and discipline with which adherence to the Province's social and economic maste1-plan, The Prosperity Plan (of which the International Strategy was an offshoot) was sought.

This policy centralization effort was significant, in that in contrast to the fragmented policy implementation that might occur in larger bureaucratıc ecosystems, New Brunswick's small size facilitated the institutionalization of narrow spans of policy flexibility This meant that deviation from or non-compliance to the Prosperity Plan and its offshoot International Strategy would be met with admonition. To drive home this point, a series of policy briefings were organized in 2002 and 2003 calling for Departments to toe the government's policy line. On the question of being "on board" with those policies, the one Deputy Minister pointed out,

The Prosperity Plan was our core economic agenda. Departmental initiatives had to be on the agenda to move forward. This was a reminder to civil servants of how priorities got set and policy items approved through the Policy and Priorities Cabinet Committee process. It was not 'on board' as to 'you personally had to believe in and support' the

\footnotetext{
345 Interview with Kevin Malone, Secretary to Cabinet, Fredencton, Fall 2003.

346 "New Brunswick is a small province, and the challenge of having limited resources to pursue our interests with required adoption of focused policy frameworks designed to meet our objectıve of social and economic prosperity. Having a formal strategy helps us, and me, to explain to c1vil socrety the policy direction of the government as adopted by Cabinet." Interview, Bernard Lord, Piemier of New Brunswick, Apı11 16, 2004
} 
Prosperity Plan. It was "on board" in the sense of developing ideas and initratives that fit and reflected the agenda Either you have a plan or you do not. We had a plan. ${ }^{347}$

This discussion of the politics surrounding the Prospenty Plan is significant in that it depicts a policy environment where extremely powerful "top-down" pressures are exerted on Ministries to support centrally-driven policy frameworks. This policy environment would in turn pave the way for IGA to articulate an International Strategy with little internal resistance at the outset. Grudgingly or otherwise departments would participate in the International Strategy process lest their respective Deputy be summoned to the Premier's Office for a dressing down. The support IGA received was ultimately manifested in the form of departmental engagement in the development of the Internatıonal Strategy, incorporation of its recommendations into Ministries' existing budgets, and proactive adoption of action priorities by those Ministries for implementation. Given that limited financial and human resources are allocated on the basis of departmental support of the government's agenda, the stage was set for provincial government support of the International Strategy whether they agreed with it, or not.

The year and a half long process of developing the International Strategy, which included regular meetıngs of an International Strategy Workıng Group (ISWG), roundtable panels and external stakeholder meetıngs forced provincial officials to work together in a collegial (if not occasionally heated) manner, which over tıme helped break down silos

347 Interview, David McLaughlin, Deputy Minister, Commission on Legislative Democracy, Aprl 2, 2004. 
within government. In buteaucratic organizations, the silo factor has the effect of perpetuating a parochal and isolated departmental approach to the work of government, and preventing the mobilization of shared fiameworks and promotion of horizontal management. ${ }^{348}$ As studies in public administratıon demonstiate, "turf" in government departments is oftentımes jealously guarded against incursions from other inter and intradepartmental actors, and 1oles and responsibilities are defended against the peiceived efforts of other bureaucratic actors to strip those responsibilities away, take undeserved credit for corporate successes, or create the pretext for reallocation of budgetary resources.

While such bureaucratic tensions exist in New Brunswick (as they do in most government ecosystems) highly horizontalized and integrative techniques used to administer the work of the ISWG promoted cooperation, and for the first time facilitated meanıngful and structured intra-governmental networking, dialoguing and informationsharıng. Policy synergies were 1dentıfied, inter-departmental cooperatıon was harnessed and IGA promised that departmental interests and autonomy would be respected, not steamrolled over in the name of efficacy. The International Strategy noted,

Ministers will continue to exercise full authority over their respective departments' international activities. At the same time, the Department of Intergovernmental and International Relations will provide a leadership role in the implementation of the government's international agenda at a

348 The importance of promoting horizontal management and intra-bureaucratic collaboration is elaborated in Canadian Centre for Management Development, Moving from the Herolc to the Everyday: Lessons Learned from Leading Horizontal Projects, Ottawa $2001 \cdot 2$, where one participant notes that horizontal management is the challenge of "bringing diverse people together and lining up authorities in a complementary way to achieve a common purpose." 
strategic level and ensure cooperation, communications and coordination between departments and with the province's international partners ${ }^{349}$

Post-release, McKay further explained the role of IGA in this piocess:

The Department's role is to coordinate acioss government various international activities that are implemented by line departments. The Department ensures that the strategy's activities contribute to the Province's prosperity goals, and positions the Province in the international marketplace ${ }^{350}$

To allay concerns that IGA sought control over the Province's international policy to the detrıment of line department autonomy, the Deputy Minıster of IGA who had been asked to chair development of the International Strategy requested that the Deputy Minister of BNB co-chair the process. The Deputy Ministers' Steering Committee they headed up was supported by the ISWG, which in turn was comprised of provincial department representatives whose ministries had international actıvities. ${ }^{351}$

Over approximately 18 months in 2002 and 2003 the ISWG met as a group on a bimonthly basis, and in smaller groups on an ad hoc basis. During these meetıngs departments reviewed their respectıve strategic plans and stakeholder interests to identıfy opportunities for international policy development and advancement. A major factor which facilitated intensive internal-to-government dialogue was precisely what has

349 Province of New Brunswick, International Strategy, 2003: 25.

350 Interview, Jim McKay, Deputy Minister, IGA, May 11, 2004.

351 Member departments of the ISWG were: IGA, BNB, Service New Brunswick, Education, Training and Employment Development (which included the community colleges), Health and Wellness, Agriculture, Fisheries and Aquaculture, Tourism, the Office of Human Resources, and ECO on an intermittent basis 
earliet been noted as a challenge New Biunswick's small size With the small size, however, came intensely peisonal rclationship building between departmental 1epresentatives who accepted at face value IGA's assurance that their participation in the ISWG would be meaningful, existing or prospective international departmental objectıves would not be compromised or circumvented, and departmental initiatives would receive corporate exposure and support to assist in their implementation

One of the ISWG co-charrs noted,

The simple fact of engaging all pattes was important Although the process developing a strategic framework is not normally perceived as something 'real,' such as a piece of infrastructure, the value of engaging all parties and promoting a convergence of interests is important ${ }^{352}$

The following sub-section of this discussion of the Province's internal strategic interests takes a close look at programs and procedures that were introduced and administered by IGA with respect to the provincial government's internal mechanics under the aegis of the International Strategy, which in turn provide deeper insight into problems which would later arise

Internatıonal Travel Advisory

Although not an initiative originally articulated in the International Strategy, the introduction of the International Travel Advisory (ITA) policy is highly symbolic and 
repiesentative of the disjuncture between the Province's intended use of its International Strategy and the way it was actually implemented The ongmal intent of the ITA was relatively straightforward, but does require some advance knowledge of the internal process of governmental international travel approvals. Its significance to this study of New Brunswick's international policies and practices is considerable as demonstrated in the following pages.

Prior to the introduction of the ITA, government officials wishing to travel internationally were required by Board of Management (BOM) to formally request permission to travel from the Deputy Minister responsible or his/her designate as per the Provincial government's travel policy. The required international travel would take place, after which the Deputy's approval would authorize for the disbursement of expenses to the employee for travel-related costs incurred. ${ }^{353}$

From an operational and policy perspective, the administrative procedures related solely to grantıng of permission to travel on a department-by-department basis and pay-out of incurred expenses as opposed to promoting overall government efficacy. This is to say, prior to the introduction of the International Strategy, the New Brunswick government was more concerned with approval and expense-oriented process management than with promoting optımization of international travel through inter-departmental collaboration, information-sharing and cross-taskıng where appropriate or required. As a result, it was not uncommon for New Brunswick government officials to inadvertently bump into one 353 See Chapter F-11, Section 6(1)(h), New Brunswick Financial Administration Act, relevant BOM Minutes, and New Brunswick Travel Policy, Administration Manual (volume 2), May 2008. 
anothe1 in faraway international destinations while on public business, or miss opportunities to shate information on international relationships and oppoitunities in anything other than ad hoc and cricumstantial situations In one instance, a Deputy Minister who shall remain unnamed recollected that he/she bumped into a Ciown Corporation colleague in a hotel in Tha1land unexpectedly On asking the nature of the other's visit, he/she was surpised to learn that despite working in adjacent offices, they were to attend the very same conference

The ITA was introduced to government in the Sping of 2004 by IGA, 1ts goal was to collect information on where government officials were travelling in advance of the travel so that the corporate interests of government could be pursued in a coordinated, informed manner Kershaw notes, "When we conducted an inventory of our international travel within government, the range and scope of our global activities surprised a lot of people $" 354$

Initially, all departments in Part 1 of the Public Service (central agencies and line departments) were requested by IGA to participate in the ITA by ensuring that internationally-bound employees fill in a one page questionnaire in addition to the paperwork required by BOM Information that was collected on who was going where would then be strategically shaied with all travelling employees, but this practice was modified by mid 2004 to include distribution to only Deputy Ministers Given the small size of the New Brunswick Public Service, the sharing international travel habits and

354 E-mail from John Kershaw, Januaty 14, 2004 following up on discussion regarding New Biunswick's International Strategy 
practices of employees soon demonstrated there were different and conflictıng views on what some Depaitments deemed as necessary international tiavel from other employees, which in tuin evoked a negative 1eaction fiom Deputy Minısters who viewed the added information-gathering by IGA with some degiee of suspicion Several of the interviewed officials, cited and anonymous, noted that acimony over "who got to go where" was at tımes bitter Busıness New Biunswick, whose p1101 title was the Ministry of Economic Development and Tourısm (EDT) was derısively dubbed the Minıstı y of "Eat, Dink and Tiavel" on account of considerable travel undertaken by its investment attraction aim

An anonymous public servant in a line department who was on the original recipients' list noted on condition of anonymity,

To me, there were three dangers of a broad distribution fisst, the fact that, given the financial situation of the Provincial Government, the significant amount of international travel that was taking place could have been misinterpieted if the list became public, second, the fact that many Departments had significantly cut back travel as a result of budget issues and a broad circulation of the list may generate unrealistic expectations with respect to travel, and, three, over time as individuals made individual trips abroad - for very specific purposes - the distribution list could have become very substantial ${ }^{355}$

\begin{abstract}
Although another layer of bureaucratıc red tape was created by adding the ITA questionnaire to an alieady cumbersome international travel approvals process that involved cost estımates and multıple-levels of approval through the managerial hierarchy, IGA's efforts were tolerated for the meanwhile given the laudable and defensible intent to collect and shate infor mation with three objectives in mind
\end{abstract}

3ग0 Fall, 2008 
a) Inculcate corporate memory of government-related international activities;

b) Coordinate international work plan itineraries to senior managers prior to date of travel; and

c) Facilitate introduction to federal government officials at High Commissions and Embassies in the concerned countries of travel.

While pursuit of these objectives was not opposed, the second and third in particular were viewed with some degree of suspicion and concern from Ministries. The fear, as expressed by public servants with whom the issue was discussed, had to do with IGA's collection of information for the purpose of influencing (or changing) what line departments defined as their own international activities. Given the top-down policy implementation of the government, however, any such lingering concerns regarding IGA's incursions and interventions into what were essentially departmental activities remained unvoiced and unexpressed.

Given the prima facie logic of the ITA as a tool to promote horizontal management and administration, the Premier's Office issued a government department-wide directive for all Deputies to establish that the ITA was a required protocol for all international travel. It only made sense, as drawing from the International Strategy's commitment to more effectively manage resources and promote increased coordination of efforts and resources, that the ITA sought to promote greater teamwork and "cross-tasking" of provincial officials, and has reduced the duplication of international travel expenses. 
By late 2004, the ITA was at a nearly $100 \%$ capture 1 ate of all international tiavel engaged by departments However, an incident conceining two Ministeis tiavelıng to Fiance at approximately the same time claiming the same objectives resulted in the Piemier's Office authorizing the Deputy Minister of IGA to reject any inteinational travel (alieady approved by another Deputy Minister) deemed to be corporately non-essential or potentially politically awkward This created internal and buieaucratic pushback against IGA, forcing it to 1einforce corporate adherence to all Deputy Ministers

You are ieminded of the directive from the Premier's Office in December 2003, that all international travel is to be reviewed by the Department of Intergovernmental and International Relations and approved by the Premier's Office Departments are to proceed with international arrangements only when approved. This brings a corporate and strategic approach to all international travel. ${ }^{356}$

For nearly two years after this admonition the ITA performed well in its new incarnation. While internal complaints regarding its centralıst modus operandi flowed to IGA, the advisory remained in place. By 2007 and the installation of the new Liberal government, however, the Deputy Minister of IGA informed his Deputy counterparts that the ITA would be disbanded, international travel information and activities would no longer be centrally collected, and that individual Deputy Ministers would return to being the final appiovers of international travel by their employees.

While the ITA made sense in principle, it was fraught with implementation-related difficulties since inception for several ieasons One, while IGA (as an expression of its 356 Memoranda to All Deputy Ministers, "International Corporate Travel," Office of the Deputy Minister, IGA, October 5, 2005, (acquired through written request to IGA) 
"ownership" of the intergovernmental telations buteaucratic function) sought to use the ITA as a means to assist hne depatments with their international activities thiough proactive networking with federal government officials situated abroad, line departments frequently sought out their own relationships and side-stepped what they viewed as IGA's desire to bioker relationships and acco1d to itself or gantzational significance

Second, the ITA application process was held in disdain by line departments who loathed the prospect of having departmentally-approved international travel approval forms subject to approval by IGA, and were resistant to sharing information on their whereabouts, business activities and contacts/relationships with other actors across government This tension speaks directly to the struggle for control of the Province's international policy agenda between central agencies and line departments, a problem that never entirely went away during the Lord adminıstration. On a related note, departments also reacted poorly to having to complete two forms for international travel, only one of which was legally required by Board of Management, especially since IGA took little initiative to attempt synchronizing the ITA with the existing BOM approvals process. This administrative inefficiency was evident within even IGA, where ITA questionnaire data was received in Word format from departments and re-entered into the departmental (legacy software) database by hand, after which IT limitations inherent to the database architecture made running even the most rudimentary information reports a laborious (1f not impossible) undertakıng. 
Third, from an operational perspectrve IGA had originally intended that the ITA serve as a source of information for internationally-active officials of the New Biunswick government, and that this information would flow fiom the Deputy Minister to the appiopriate staff downwatds through the chan of command Anecdotal information gained thiough discussion with repiesentatives of various depat tments, however, 1evealed that this t11ckle-down of information for the most part simply did not happen ${ }^{357}$ On a regular basis, quarterly convened meetıngs of the Province's internal International Strategy Workıng Gioup suggested that ITA weekly repoits sent to Deputy Minısters did not tianslate into gieater organizational or international actıvity-related awareness

Fourth, if there is truth to the argument that the degree of importance of a given policy or process is commensurate with the intensity of its human and capital resourcing, IGA took little initiative to migrate the ITA away from its archaic database platform and towards the Oracle architecture that the Province's central IT department was encouraging that all legacy databases be converted into IGA's preference for the status quo was currous, in that a database changeover from FleMaker Pro to Oracle would have allowed integration of ITA reports with actual international travel expense reports housed within the Office of the Comptroller, thereby allowing a highly accurate picture of "who was going where, and at what price"

Perhaps the larger issue in this last respect had to do with the inherently incompatible bureaucratic cultures and stiuctures between IGA, the Comptioller's Office, line departments and the Ptemier's Office, all of which had the cumulative effect of 357 BNB, Education and even IGA 
highlightıng the lack of shared and unifyıng values Moreover, one cannot help but think that one of the main challenges to the success of the ITA, and the International Strategy 1tself, was a petvasive sense between Departments that grand stıategies and approaches that seemed rational at the centre had little effect or significance on the day-to-day work of government

While the ITA initiative did not involve significant consideration of human or financial resources, the larger implementation of the International Strategy had significant budgetaty implications The following section discusses some of those considerations.

\section{Budgetary Allocation}

The International Strategy was approved by Policies and Prorities Committee of the Executıve Council prior to its tabling in the New Brunswick Legislative Assembly in the Spring of 2003. While the policy was approved on the merit of its policy efficacy, it was not brought forward to the Board of Management Committee of the Executıve Council with a request for financial resources earmarked for its implementation

While the precise reasons why IGA did not go to BOM for approval of financial resources to implement the International Strategy have pioved elusive to pinpoint, despite years of research and asking questions within the decision-making strata of the New Brunswick government, three possible results for the International Strategy not being accorded a budget for program and service implementation were realızed 
a) Not all of the 58 action pilorities contained in the International Strategy could be implemented,

b) The strategy would be implemented at the expense of one of more provincial government departments, or

c) Action pirorities to be reported as completed would be departments' status quo activities teported such that they appeat to be newly-completed action pirorities, which for the most part ielates to those policies implemented in point a) above

While it was aigued by Intergovernmental Affarrs that the International Strategy was implemented by virtue of inter-departmental collaboration and financial coopeiation, thereby distributing costs across a number of departments, ${ }^{358}$ the lack of a specific earmarked budgetary allocation for implementation of the International Strategy had significant consequences discussed near the end of this Chapter Moreover, the lack of stand-alone funding for the (coordination of) implementation of the International Strategy for IGA reinforced the notion that there were inconsistencies between the Province's stated objectives and its preparedness to dedicate hard resources to the task at hand This situation does not seem to have changed substantıally from the late $1980 \mathrm{~s}$, when Nossal while examining the international activities of small provinces noted that while "Ontario and Alberta both have modest intergovernmental affarrs agencies created in the late 1970s [ ] Nova Scotia, New Brunswick, Manitoba, and Britısh Columbia have not institutionalized to this extent, their governments content to conduct their international relations in an ad hoc and centralized fashion "359 The significance of Nossal's

\footnotetext{
$358 \quad$ Interview, Mirelle Cy1, Assistant Deputy Minısteı, FOLB, January 14, 2009

359 Nossal, The Politics of Canadian Foreign Policy, 1989266
} 
observation lies not in the fact that small piovinces don't have the same resources as larger ones, but in the fact that despite nearly 20 years of active international affais, the Piovince of New Brunswick farled to allocate stable, piedictable funding for 1ts first and only formally-artıculated Internatıonal Strategy.

Last, implicit in the Province's farlure to fund the International Strategy, there was an underlying belief (rightly or wrongly) that the federal government was in a position to provide financial assistance for 1 ts implementation. In correspondence concerning provincial concerns over jurisdictional creep Kershaw noted that,

The sub-state's engagement in foreign affarrs is to protect their Constitutional areas of jurisdiction, especially given enhanced levels of international trade agreement negotiations. This is true. But it is also true that NB also wanted to create a context to engage the federal government in a very positive and collaborative way, recognizing 'we needed them and their resources.' So it was not driven solely from an us-versus-them context. $^{360}$

\section{Other Aspects of Federal-Provincial Collaboration and the International Strategy}

Development of the New Brunswick's International Strategy involved consultations between the Province and external stakeholders, including the federal government, academia, private sector and community groups and organizations, cutting across both Anglophone and Francophone segments of the populace. ${ }^{361}$ These consultations were

360 E-mail correspondence, John Kershaw, Deputy Mınıster, IGA, September 30, 2003.

361 For example, on September 5, 2002 the following stakeholders were invited to join with Provincial officials to determine prionties that should be reflected in a holistic 
conducted in part due to the province's desire to engage its small-size as a means to conduct consultations with actors outside of government as a means to obtain new 1deas as well as placate potential opponents who would claim that the Province farled to seek their input on the design of the International Strategy Pilor to the development of the International Stiategy, the P1osperity Plan noted,

New Biunswick's small size can be an advantage in today's globally competitive economy when speed and collaboration count By forging an ' $\mathrm{N} B$ Inc' approach of linking all of the partners together, we can find more effective ways to compete with other juirdictions [ ] NB Inc is our definition of an integrated strategic partnership amongst governments, business, workeis, communities, universities and other learning and research institutions Each of these partneis has a crucial 1ole in bringing about prosperity Each has a leading role in some areas and a supporting role in others By having all partnets share a common vision, we can all move together in a common direction From "thinkıng together" to "acting together', the N B Inc Strategic Partnership will enhance our collective ability to achieve prosperity more quickly and effectively ${ }^{362}$

As one of Canada's smallest provinces that relied heavily on federal government support, ${ }^{363}$ IGA felt 1t was necessary to engage Ottawa from the outset The spec1fic purpose of this cooperative approach was to access the federal government's corporate

International Strategy ADI Limited-Andrew Steeves, Vice-President, ACOA- Daiyell Nowlan, Strategic Development Officer, CGI- Dan McBride, Vice-President, DFAITJohn McDowell, Dilector, Federal-Provincial-Territorial Relations, Lyceum- Ken Kıerstead, Pıesident and CEO, Mathıs Instıuments, Chıs Mathıs, Engıneerıng Manager, NB Trainıng Group Inc - Gwen McKay, Pıesıdent, Théorıx- Jean Nadeau, Pıesıdent and CEO, Theımopak- Bernaid Morın, Presıdent and CEO, Unıversıté de Moncton, Yvon Fontaine, Recteu1, University of New Brunswick- John McLaughlın, Piesident

362 Province of New Biunswick, 200237

363 Donald Savore more fully artıculates this point in "Pulling Against Gravity Economic Development in New Brunswick During the McKenna Yea1s", Institute for Research on Public Policy (Winter 2001) Of particular interest is Savoie's elaboration on the concept of "supplication" and New Brunsw1ck's economic dependency on the federal government in most matters relating to economic and industrial capacity-building 
knowledge of fore1gn affarrs, mult1-sectoral networks in foreign markets, as well as better understand the multitude of international programs and services outreach programs avarlable to provincial governments to pursue their international interests. DFAIT was the main federal department whose input was sought, and of particular relevance was the Federal-Provincial-Territorial (CFP) division, which as the bilateial relationship between IGA and CFP intensified, helped as a facilıtator when IGA sought meetings, information or connections within the federal government The benefits of collaboration were profound.

Without having a clear international affarrs task upon which to concentrate, personal and professional connections established at the operation and executive level of both jurisdictions would likely not have happened. Upon completion of the International Strategy, Internatıonal Trade Minıster Pierre Pettıgrew and Foreign Affarrs Minister Bill Graham recognized the collaboratıve intergovernmental role that New Brunsw1ck sought with the federal government through DFAIT in a jointly penned letter to Lord.

We understand that officials from the Department of Foreign Affairs and International Trade offered advice and guidance to the province during the design and drafting of Prospering in a Global Community. We believe that the close rapport established between the two levels of government during the last six months is an excellent example of collaborative federalism. The resulting achievement showcases New Brunswick's willingness to work to forge new partnerships and strengthen existing ones, as well as its forward-thinking commitment to adaptation and innovation.

Acknowledgement of the growing inter-bureaucratic relationship was also noted, 
We want to offer ou1 continued support in the implementation of New Biunswick's international stiategy We undetstand that department officials are already in contact with then counterpat in New Biunswick's Depattment of Intergovernmental and International Relations to discuss conciete ways in which we can assist in this regard ${ }^{364}$

Duing those bilateral meetings the Province acknowledged the role played by the Government of Canada in fore1gn affaris and fore1gn policy, ${ }^{365}$ and in 1eturn, DFAIT officials pointed out that globalization had indeed created new challenges and opportunities for provincial governments to be active in international affairs, and that federal officials at headquarters and posted abroad would rededicate themselves to working with New Brunswick and its International Strategy objectives

Drawing on earlier-posed questıons regarding why DFAIT might be so eager to assist New Brunswick in the development and implementation of its International Strategy, it is 1mportant to determine what interests were at play. Was Ottawa playing a complex, mult1-tiered game in which its cooperation with New Brunswick was meant to draw attention away from its incursions into areas of provincial jurisdiction such as the environment and education? Was Ottawa's main interest mitıgating the autonomous actions of larger provinces on the world stage? There is evidence of the latter, and undertakings such as the New Brunswick International Day in Ottawa and the

\footnotetext{
364 Department of Foreign Affarrs and International Trade, Ministers Pettıgrew and Graham, Letter to Premier Lord, August 13, 2003

365 "The Province of New Brunswick will continue its tradition of supporting Canada in the international arena Our interests are closely aligned with those of Canada and we will work within the federation to promote a strong and unified approach The Province of New Brunswick will continue to work actively to promote and support Canada's enviable international image." Province of New Brunsw1ck, International Strategy, 2003 24
} 
International Business Symposium which are discussed below help obtain a better understanding on how the fedeıal government pursued those interests, and how New Brunswick allowed itself to be used to pursue those interests

New Brunswick International Day in Ottawa (NBIDO)

In orde1 to recognize New Biunswick's development of the International Strategy and demonstrate the federal government's appteciation of the collaboratıve federalist sentiment that underscored New Brunswick's pursuit of its International Strategy and paradiplomatic interests, DFAIT offered to host a "New Brunswıck Internatıonal Day in Ottawa" (NBIDO) on March 9, 2004

The goal of this day was to bring together senior departmental executives from both levels of government to promote greater intergovernmental collaboration in the implementation of the International Strategy, as well as proactively draw in federal executives with the organizational clout to make things happen. The day to be hosted at the Pearson Bulding in Ottawa consisted of: Premier to Prime Minister and Minister to Minister meetıngs, plenary sessions; Premier Lord addressing the entıre assembled foreign diplomatic corps in Ottawa in the Marcel Cadieux Auditorium, Premier Lord facilitating a Question and Answer session with DFAIT employees, a formal luncheon and reception with invited political dignitaries, and a separate Francophonie track in which issues particular to New Brunswick's participation in La Francophone were discussed 
The two Ministers responsible for DFAIT's commercial and political functions were supportive of the initiative Foreign Affais Graham noted, "Reflectning the Prime Ministel's commitment to build stiong and cooperative relations with the provinces and teritories, this first provincial international day sets a new precedent for federalprovincial engagement and dialogue [ ] The various meetıngs held today are an excellent demonstration of these renewed and expanded ties with the provinces and territories" International Tiade Minister Jim Peterson echoing the sentiment that, "A coordinated approach on trade and investment is key to our collective success on the world stage [ ] I look forwaid to wotking closely with New Brunswick to increase commercial flows to and from the province and to attract and retain additional investment, 366

Even the grand front lobby of the Pearson Bu1ling was transformed into a testament to New Brunswick's partnership with DFAIT, with renowned Ganong chocolates and Connors Brothers canned fish being passed out to building staff, in addition to more conventional paper collaterals Internatıonal Trade Deputy Minıster Leonard Edwards and Foreign Affairs Deputy Minister Peter Harder wiote,

By for ging closer working relatıonshıps and facilıtatıng dialogue, the New Brunswick International Day in Ottawa has the potential to benefit both the federal government and the Province of New Biunswick From the federal perspective, we welcome the opportunity to gain further insights into New Brunswick's International Strategy, as well as the province's interests and perspectives We also look forwaid to presenting our priorities, programs and services The New Brunswick International Day

\footnotetext{
366 DFAIT, News Release, "Canada and New Brunswick Discuss Enhanced International Cooperation," March 9, 2004
} 
should encourage frutful discussion and he occasion to examine possible synergies and areas for collaboration ${ }^{367}$

At the culmination of the NBIDO the following initiatives were announced: ${ }^{368}$

- Federal-provincial co-hosting of an International Business Symposium to reach out to provincial businesses to promote fedeial services and programs to maximize partnership opportunities,

- Create a partnership between the University of Moncton and the University of New Brunswick to create an Institute for International Studies,

- Endorse creation of a Congress of young Franco-Canadians on democracy and cultural diversity in preparation for the 2004 Sommet de La Francophonie;

- Funding for two projects in New Brunswick under the Young Professionals International 1nitiative with the Falls Brook Centre in Knowlesville NB and the Faculty of Forestry, University of Moncton, Edmundston Campus.

- Signing of MOU on Canada's Financial Contribution to New Brunswick's participation in La Francophonie for 2004-2005 valued at \$1 million.

The following pages will take a closer look at the International Business Symposium noted above.

367 Deputy Ministers Leonard Edwards and Peter Harder, Letter to the Deputy Minister of IGA (New Brunswick, September 30, 2003).

368 For additional information see Province of New Brunswick, News Release, "New Brunswick International Day Takes Place in Ottawa," March 9, 2004. 
International Business Symposium (IBS)

Another example concerning how the Province and federal government sought to identify concrete ways in which to collaborate on advancement of mutual international goals is manifested in the International Business Symposium (IBS), an action priority contained in the International Strategy and announced at the above NBIDO. ${ }^{369}$ The IBS was intended to be a two to three day event designed to reciprocate DFAIT's hosting of the NBIDO in New Brunswick and enhance the federal government's familiarity with New Brunswick. The main federal participants were intended to be Canadian Senior Trade Commissioners (STCs) posted in European missions. Slated to take place in September 2006, the IBS also sought to bring New Brunswick to top of mind when Canadian commercial officers qualified inwards investment leads, export opportunities and technology transfer opportunities. New Brunswick's small size and diminished financial capacity to act unilaterally in world markets made this relationship-leveraging initiative highly attractive.

While the Province had originally committed to holding the IBS in the Fall of 2003, lack of a stand-alone implementation budget (as previously discussed) meant that no one provincial department would agree to take ownership of the action priority. Ultimately, operational funding came from the Departments of IGA, BNB and Training and Employment Development (TED), each with an equal financial stake. Transitioning the

369 The Province committed to "Host an International Business Symposium in the fall of 2003 bringing together international experts, business and key federal and provincial agencies." Province of New Brunswick, International Strategy, 2003: 14. 
policy commitment towards actual implementation, howeves, would hkely not have happened unless it was spurred on as a follow-up initiative to NBIDO

But despite having commitments from nine Canadian missions in Europe to attend the IBS along with a financial and human resource commitments from DFAIT headquarters in Ottawa, the 2006 provincial election and the change in governing parties resulted in the postponement of the IBS. In the letter sent to DFAIT requesting that the proposed IBS not take place, it was noted by the IGA Deputy Minıster that,

I hope this spirit of federal-provincial collaboration will continue as we explore alternate dates for this event of significant importance in the context of New Brunswick's need and desire to expand its trade relatıons in Europe [...] The core element of this symposium is the participation of our federal trade officials posted in Europe and we thank you for kindly agreeıng to come to New Brunswick. ${ }^{370}$

While the IBS never happened on account of the 2006 New Brunswick election, at which tıme Lord's Progressive Conservatıves lost power, the initıatıve was sıgnificant in that it was seen as a way to leverage federal-provincial collaboration and demonstrate that New Brunswick's International Strategy hinged on cooperatıve efforts, unl1ke some of the larger provinces like Québec. That sa1d, while the NBIDO was a means with which to implement the International Strategy and the IBS did not happen the significance of both initiatives lay in their symbolic and practical integration of New Brunswick and the

$370 \quad$ Province of New Brunswick, Memoranda, "Postponement of International Business Symposium," Department of Intergovernmental Affarrs, Province of New Brunswick, August 18, 2006 (obtained through written request to IGA) 
federal government's efforts Collectively, the initiatives iepiesented efforts to maximize New Brunswick's standing with DFAIT as well as raise attention to 1ts policy interests

\section{Assessing Implementation}

As a measure of public accountability, the International Strategy committed to measure implementation of the 58 action prionties it contained with the Return on Investment factors earlier outlined in Table 8. Based on these "indicators," the International Strategy committed the Province to 1ssuing an annual report card to New Brunswickers consisting of a consolidated statıstics package ${ }^{371}$

In January 2006 the Province of New Brunswick released the Progress Report on Prospering in a Global Community: New Brunswick's Internatıonal Strategy. The report was prepared by IGA, which collected information on what action pronities were fulfilled and which ones were not, through consultation with departments through quarterly meetıngs of the ISWG. Chapter 5 will take a closer look at the International Strategy's evaluation, focussing on aspects of process evaluation and assessing the true impact of action priorities artıculated in specific areas In short, however, IGA's hope that departments would "self assign" 372 therr own department's tasks associated with the International Strategy was met with mixed results A table overviewing the International Strategy's 58 action priorities and the Province's assessment on whether each was

371 Province of New Brunswick, International Strategy, 2003: 26

372 Interview, Arnold Kearney, Director, FOLB, March 29, 2004 
fulfilled as per the 2006 Progress Report on the International Strategy is included in Appendix A of this Chapter.

With this overview of New Brunswick's International Strategy in hand, the following chapters of this dissertation delve deeper into specific policy issues in which New Brunswick's interests run parallel, intersect and come into conflict with those of the federal government due to inter-jurisdictional concurrency. 
Appendix "A"

\begin{tabular}{|c|c|c|c|}
\hline \multicolumn{4}{|c|}{ New Brunswick International Strategy Action Priorities } \\
\hline Act & Ion Prionty & Lead & Status \\
\hline \multicolumn{4}{|c|}{ Investment and Trade } \\
\hline 1. & $\begin{array}{l}\text { Pursue new international investment into the } \\
\text { province consistent with our Prosperity Plan taigets. }\end{array}$ & BNB & $\checkmark$ \\
\hline 2. & $\begin{array}{l}\text { Pursue Integrated Trade Strategy with increased } \\
\text { focus on Designated Target Markets }\end{array}$ & BNB & $\checkmark$ \\
\hline 3. & $\begin{array}{l}\text { Strengthen our partnership with the federal } \\
\text { government in pursuing our investment and trade } \\
\text { interests }\end{array}$ & $\mathrm{BNB}, \mathrm{IGA}$ & $\checkmark$ \\
\hline 4. & $\begin{array}{l}\text { Strengthen our partnership with business and the } \\
\text { academic sector in developing and pursuing trade and } \\
\text { investment opportunities. }\end{array}$ & $\begin{array}{l}\text { ED, IGA, } \\
\text { SNB, TED }\end{array}$ & $\checkmark$ \\
\hline 5. & $\begin{array}{l}\text { Work with the federal government to enhance the } \\
\text { movement of people, goods and services across the } \\
\text { New Brunswick/Maine border through infrastructure } \\
\text { 1mprovement and risk management programs. }\end{array}$ & $\begin{array}{l}\text { DOT, } \\
\text { NBCC }\end{array}$ & $\checkmark$ \\
\hline 6. & $\begin{array}{l}\text { Enhance our corporate approach to participating in } \\
\text { Team Canada and Team Canada Atlantic trade } \\
\text { missions in close partnership with our business and } \\
\text { academic community. }\end{array}$ & BNB & $\checkmark$ \\
\hline 7. & $\begin{array}{l}\text { Identify and request the support of trade and } \\
\text { investment champions currently residing in, or } \\
\text { familiar with, the province's designated target } \\
\text { markets. }\end{array}$ & & \\
\hline 8. & $\begin{array}{l}\text { Focus the presence of New Brunswick's investment } \\
\text { and trade officers in the designated target markets. }\end{array}$ & BNB & $\checkmark$ \\
\hline 9. & $\begin{array}{l}\text { Explore new markets for New Brunswick's cultural } \\
\text { products. }\end{array}$ & $\begin{array}{l}\text { BNB, CSS, } \\
\text { IGA }\end{array}$ & $\checkmark$ \\
\hline 10. & $\begin{array}{l}\text { Continue to assist provincial companies to be export } \\
\text { ready and facilitate contact between export ready } \\
\text { companies and Canada's export trade services. }\end{array}$ & BNB, IGA & $\checkmark$ \\
\hline 11. & $\begin{array}{l}\text { Seek new trade and investment markets within La } \\
\text { Francophonie. }\end{array}$ & $\begin{array}{l}\text { BNB, IGA, } \\
\text { TAP, TED }\end{array}$ & $\checkmark$ \\
\hline
\end{tabular}




\begin{tabular}{|c|c|c|c|}
\hline 12. & $\begin{array}{l}\text { Host an International Business Symposium in the fall } \\
\text { of } 2003 \text { bringing together international experts, } \\
\text { business and key federal and provincial agencies. }\end{array}$ & $\begin{array}{l}\text { BNB, IGA, } \\
\text { TED }\end{array}$ & $\checkmark$ \\
\hline 13 & $\begin{array}{l}\text { Explore new partnership and delivery models for } \\
\text { trade and investment currently underway in other } \\
\text { jurisdictions to assess the potential merits of } \\
\text { application in the province. }\end{array}$ & & \\
\hline 14 & $\begin{array}{l}\text { Pursue partnerships with the private sector to } \\
\text { package health and education related products and } \\
\text { explore markets where potential return on investment } \\
\text { is high. }\end{array}$ & $\begin{array}{l}\text { ED, NBCC, } \\
\text { TED }\end{array}$ & $\checkmark$ \\
\hline 15 & $\begin{array}{l}\text { Continue to participate actively in the Conference of } \\
\text { New England Governors and Eastern Canadian } \\
\text { Premiers Standing Committee on Trade and } \\
\text { Globalization and the Northeast International } \\
\text { Committee on Energy to address trade corridor, trade } \\
\text { policy, trade promotion, energy and other issues of } \\
\text { regional concern. }\end{array}$ & IGA & $\checkmark$ \\
\hline \multicolumn{4}{|c|}{ Immigration } \\
\hline & $\begin{array}{l}\text { Develop a comprehensive Immigration Strategy and } \\
\text { modernize its Provincial Nominee Program } \\
\text { consistent with strategic recruitment, retention and } \\
\text { repatriation targets. }\end{array}$ & BNB & $\checkmark$ \\
\hline 17 & $\begin{array}{l}\text { Pursue a new partnership model with the federal } \\
\text { government on immigration. This new arrangement } \\
\text { will include entering into a formal arrangement with } \\
\text { the federal Department of Citizenship and } \\
\text { Immigration to set out specific objectives and } \\
\text { targets. The Province of New Brunswick will work } \\
\text { with local and overseas federal immigration offices } \\
\text { to build awareness of the Province of New } \\
\text { Brunswick's immigration interests and objectives. }\end{array}$ & PNB & $\checkmark$ \\
\hline 18 & $\begin{array}{l}\text { Enhance its ongoing presence in geographic regions } \\
\text { where recruitment potential is considered high. }\end{array}$ & BNB, IGA & $\checkmark$ \\
\hline 19 & $\begin{array}{l}\text { Advocate for the recognition of credentials and } \\
\text { qualifications from credible international learning } \\
\text { institutions for health professionals. }\end{array}$ & $\mathrm{BNB}$ & $\checkmark$ \\
\hline 20 & $\begin{array}{l}\text { Host an Immigration Conference in Saint Andrews } \\
\text { in } 2004 \text { in conjunction with the province's } \\
\text { celebration of the first European settlement in North } \\
\text { America. }\end{array}$ & IGA & $\checkmark$ \\
\hline 21. & $\begin{array}{l}\text { Strengthen its efforts to assist immigrants to settle } \\
\text { into their new lives in the province, in partnership }\end{array}$ & $\begin{array}{ll}\text { BNB, } & \text { IGA, } \\
\text { TED } & \end{array}$ & $\checkmark$ \\
\hline
\end{tabular}




\begin{tabular}{|c|c|c|c|}
\hline & $\begin{array}{l}\text { with the federal goveinment, local communities, and } \\
\text { multicultural associations }\end{array}$ & & \\
\hline 22 & $\begin{array}{l}\text { Woik with provincial universities, community } \\
\text { colleges and other recognized learning institutions to } \\
\text { encourage forergn students to settle in the province }\end{array}$ & $\mathrm{BNB}$ & $\checkmark$ \\
\hline 23 & $\begin{array}{l}\text { Woik closely with our multicultural organizations to } \\
\text { identify potential candidates for } 1 \mathrm{mmigiation} \text { and } \\
\text { encourage immigiation wheie it strengthens families } \\
\text { and meets skills iequirements }\end{array}$ & NBCC & $\checkmark$ \\
\hline 24 & $\begin{array}{l}\text { Build awareness of the benefits of 1mmigrating to } \\
\text { the province among credible emigration consultants }\end{array}$ & $\mathrm{BNB}$ & $\checkmark$ \\
\hline 25 & $\begin{array}{l}\text { Woik with business, univeisities and community } \\
\text { colleges to adopt programs that allow foreign } \\
\text { students to work in business and government as part } \\
\text { of their accreditation, allowing them to gain valuable } \\
\text { expeilence and meet Canadian work experience } \\
\text { immigiation requirements }\end{array}$ & $\mathrm{BNB}$ & $\checkmark$ \\
\hline 26 & $\begin{array}{l}\text { Encourage the fedeial government to give pirority to } \\
\text { student visa applicants destined to learning } \\
\text { institutions endorsed by the Canadian Ministers of } \\
\text { Education Council }\end{array}$ & $\mathrm{BNB}$ & $\checkmark$ \\
\hline 27 & $\begin{array}{l}\text { Actively promote the benefits immigrants offer to } \\
\text { the province, and encourage understanding and } \\
\text { active participation in fostering a positive experience } \\
\text { for new immigrants as they adjust to their new } \\
\text { environment and begin to contribute to life in the } \\
\text { province }\end{array}$ & $\begin{array}{l}\text { BNB, IGA, } \\
\text { TED }\end{array}$ & $\checkmark$ \\
\hline 28. & $\begin{array}{l}\text { Work to build awareness of the province's rich } \\
\text { francophone heritage and bilingual nature to } \\
\text { encourage settlement of new francophone } \\
\text { 1mmigrants }\end{array}$ & BNB, IGA & $\checkmark$ \\
\hline \multicolumn{4}{|c|}{ Innovation and Education } \\
\hline 29 & $\begin{array}{l}\text { Urge the federal government to establish Chairs of } \\
\text { International Studies at the University of New } \\
\text { Brunswick and the Universite de Moncton }\end{array}$ & IGA & $\checkmark$ \\
\hline 30 & $\begin{array}{l}\text { Encourage the allocation of federal and piovincial } \\
\text { funding to support univeisities and community } \\
\text { colleges establish international partnerships targeted } \\
\text { at facilitating knowledge and technology transfer }\end{array}$ & NBCC & $\checkmark$ \\
\hline 31 & $\begin{array}{l}\text { Encourage the allocation of fedeial and provincial } \\
\text { funding to support universities and community } \\
\text { colleges recruit and ietain highly talented }\end{array}$ & & \\
\hline
\end{tabular}




\begin{tabular}{|c|c|c|c|}
\hline & $\begin{array}{l}\text { tesearcheis with a proven tiack recoid of secuing } \\
\text { 1esearch and development funding }\end{array}$ & & \\
\hline 32 & $\begin{array}{l}\text { Suppoit the collective efforts of our universities and } \\
\text { community colleges to reciuit international students } \\
\text { and identify the seivice and settlement needs of } \\
\text { these students }\end{array}$ & IGA & $\checkmark$ \\
\hline \multicolumn{4}{|c|}{ International Development } \\
\hline 33 & $\begin{array}{l}\text { Align its international development efforts with } \\
\text { Canada's international development focus and } \\
\text { piograms }\end{array}$ & NBCC, TED & $\checkmark$ \\
\hline 34 & $\begin{array}{l}\text { Establish a corporate appioach to stiengthen the } \\
\text { seivices the government offeis to the business sector } \\
\text { and the academic community in their pursuit of } \\
\text { international development opportunities }\end{array}$ & NBCC, TED & $\checkmark$ \\
\hline 35 & $\begin{array}{l}\text { Work with business, ou1 communities, the academic } \\
\text { community and other interested stakeholders to } \\
\text { 1dentify prioity opportunities for international } \\
\text { development based on New Brunswick's existing } \\
\text { strengths and assets }\end{array}$ & & \\
\hline 36. & $\begin{array}{l}\text { Explore new models of collaboration between } \\
\text { business, the academic community, stakeholder } \\
\text { groups and the federal government to build } \\
\text { international development competencies and } \\
\text { credibility w1th funding institutions }\end{array}$ & IGA & $\checkmark$ \\
\hline 37. & $\begin{array}{l}\text { Pursue formal collaboration agreements with federal } \\
\text { international development funding agencies to focus } \\
\text { efforts, enhance communication, and build on } \\
\text { mutual strengths }\end{array}$ & $\mathrm{BNB}$ & $\checkmark$ \\
\hline 38. & $\begin{array}{l}\text { Establish a corporate approach to offering New } \\
\text { Brunswick public service expertise to developing } \\
\text { countries wishing to build their democratic } \\
\text { governance competencies The direct involvement of } \\
\text { the province's public service in international } \\
\text { development projects will be supported wheie cost } \\
\text { recovery is achieved through project funding and the } \\
\text { international competencies of the involved } \\
\text { employees are enhanced }\end{array}$ & IGA, OHR & $\checkmark$ \\
\hline \multicolumn{4}{|c|}{ International Environmental Stewardship } \\
\hline 39. & $\begin{array}{l}\text { Contınue to participate in the Conference of New } \\
\text { England Governors and Eastern Canadian Piemieis } \\
\text { Standing Committee on the Environment to addiess } \\
\text { climate change, mercury, acid rain and other issues } \\
\text { of regional concern }\end{array}$ & IGA & $\checkmark$ \\
\hline
\end{tabular}




\begin{tabular}{|c|c|c|c|}
\hline 40 & $\begin{array}{l}\text { Continue to contribute to the design and } \\
\text { implementation of a national climate change action } \\
\text { plan to address Canada's international obligations. }\end{array}$ & DOE, ELG & $\checkmark$ \\
\hline 41 & $\begin{array}{l}\text { Support firms with environmental expertise } \\
\text { exploring new opportunities in the global market. }\end{array}$ & NBCC & $\checkmark$ \\
\hline 42 & $\begin{array}{l}\text { Continue to ensure that our environmental } \\
\text { regulations are communicated effectively to } \\
\text { international firms interested in investing in New } \\
\text { Brunswick. }\end{array}$ & ELG & $\checkmark$ \\
\hline 43. & $\begin{array}{l}\text { Ensure that the environmental requirements of } \\
\text { governments in our designated target markets are } \\
\text { identified and communicated to our firms interested } \\
\text { in exploring these markets. }\end{array}$ & & \\
\hline \multicolumn{4}{|c|}{ Image and Reputation } \\
\hline 44 & $\begin{array}{l}\text { Develop an international communications strategy } \\
\text { highlighting our key international strengths and our } \\
\text { bilingual capacity. }\end{array}$ & $\begin{array}{l}\text { BNB, CNB, } \\
\text { IGA, NBCC }\end{array}$ & $\checkmark$ \\
\hline & $\begin{array}{l}\text { Position its corporate international communication } \\
\text { strategy to build upon Canada's high-quality } \\
\text { international image and promote a culture of } \\
\text { excellence in product and services offered by New } \\
\text { Brunswick in the international marketplace. } \\
\end{array}$ & BNB & $\checkmark$ \\
\hline & $\begin{array}{l}\text { Engage the province's business and academic } \\
\text { sectors, our communities and other stakeholders in } \\
\text { the design and implementation of the } \\
\text { communications strategy. }\end{array}$ & & \\
\hline & $\begin{array}{l}\text { Strengthen the link between our protocol services for } \\
\text { visiting delegations and our international interests } \\
\text { and ensure a higher level of corporate coordination } \\
\text { in serving the interests of international delegations. }\end{array}$ & IGA & $\checkmark$ \\
\hline & $\begin{array}{l}\text { Review its corporate and departmental web sites on } \\
\text { an ongoing basis to ensure a current and integrated } \\
\text { international message. }\end{array}$ & CNB & $\checkmark$ \\
\hline 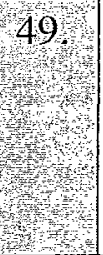 & $\begin{array}{l}\text { Initiate a Friends of New Brunswick Program that } \\
\text { identifies people from New Brunswick operating in } \\
\text { other countries, builds their awareness of New } \\
\text { Brunswick's current international activities and } \\
\text { requests their assistance in promoting our interests. }\end{array}$ & & \\
\hline \multicolumn{4}{|c|}{ International Competencies } \\
\hline 50 & $\begin{array}{l}\text { Add international diplomacy and competencies as } \\
\text { one of the training services offered to companies } \\
\text { preparing to export. }\end{array}$ & IGA & $\checkmark$ \\
\hline
\end{tabular}




\begin{tabular}{|c|c|c|c|}
\hline 51 & $\begin{array}{l}\text { Intioduce an Ambassadors' Progiam within the } \\
\text { public seivice to build international diplomacy } \\
\text { capacity and international competencies with } \\
\text { emphasis on the designated taiget makets }\end{array}$ & & \\
\hline 52 & $\begin{array}{l}\text { Introduce an Ambassadors' Progiam for Youth in } \\
\text { suppoit of New Biunswick's International Strategy }\end{array}$ & & \\
\hline 53 & $\begin{array}{l}\text { Adopt "International competencies" as part of 1ts } \\
\text { core competencies 1equirement for Executive } \\
\text { Development and Advancement }\end{array}$ & & $?$ \\
\hline 54 & $\begin{array}{l}\text { Expand the Career Management Module of the } \\
\text { Office of Human Resoutces to include an on line } \\
\text { inventory of the international expertise and } \\
\text { experience of middle to senior government officials }\end{array}$ & OHR & $\checkmark$ \\
\hline 55 & $\begin{array}{l}\text { Establish an on-line roster of New Biunswickers } \\
\text { with specialized international expertise and } \\
\text { experience that will seive as a skills inventory for } \\
\text { both the province and our international partners }\end{array}$ & NBCC & $\checkmark$ \\
\hline \multicolumn{3}{|c|}{ Other } & 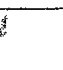 \\
\hline 56 & $\begin{array}{l}\text { The Province of New Biunswick will establish } \\
\text { Designated Target Market Advisory Committees } \\
\text { comprised of representatives of our business sector, } \\
\text { academic community, and other stakeholder groups } \\
\text { to provide input on an ongoing basis to the design } \\
\text { and implementation of action plans for the } \\
\text { province's designated target markets }\end{array}$ & IGA & $\checkmark$ \\
\hline 57 & $\begin{array}{l}\text { The government of New Brunswick is open to } \\
\text { considering new partnership models and will } \\
\text { actively engage our international partners in the } \\
\text { assessment of alternative vehicles for pursuing our } \\
\text { international interests }\end{array}$ & IGA & $\checkmark$ \\
\hline 58. & $\begin{array}{l}\text { Return on investment criteria identified earlier in } \\
\text { Prospering in a Global Community New } \\
\text { Brunswick's International Strategy will be used as } \\
\text { indicators to assess progress Data will be collected } \\
\text { to monitor these indicatois and an annual report card } \\
\text { will be issued to New Brunswickers through a } \\
\text { consolidated statistics package }\end{array}$ & IGA & $\checkmark$ \\
\hline
\end{tabular}




\section{Chapter IV: Intersecting Policies and Jurisdictions}

\section{Introduction}

To this point, this dissertation has discussed several aspects of New Brunswick's pursuit of its international interests, including. a) how size plays a factor in its paradiplomatic activities, b) the efficacy of its International Strategy, c) how its relationship with the federal government has affected pursuit of those interests, and d) conceptual aspects such as "province-bu1ling" and Garbage Can Modeling in helping us understand those efforts

This Chapter builds on that foundation and takes a closer look three areas- Trade promotion and investment attractıon; Immıgratıon; and New Brunswick's participation in La Francophonie

While most policy issues are of some degree of interest to both the provincial and federal orders of government (such as transportatıon, agnculture, fisheries, educatıon...) and will necessarily require some modicum of direct or indirect intergovernmental cooperation and collaboration, these three particular policy areas were selected given that they involve significant inter-jurisdictional concurrency and/or dependency. In these policy areas, there is a heightened importance on processes such as intergovernmental relations, executive federalısm and bureaucratıc politıcs, as both orders of government attempt to minimize frictions and optımize interest pursuit through collaborative initiatives. Through examination of the Province's promotion of tiade and investment, 1mmigration and 
relationship with La Francophonie, it is possible to also examine the synchronicity between intergovernmental entities and conflict points. The next several pages provide a brief, high-level overview of these policy areas and their relevance to this study, and lays out the framework with which each is analyzed.

In the case of trade and investment promotion (the two most important functions of regional economic development) the federal-provincial relationship is generally noted to be productive and collaborative, and efforts have been made to integrate the activities of both orders of government, as well as engage in joint activities where possible. In the case of immigration, it was noted that the federal-provincial relationship was more strained and bordered on conflictual given the degree of incompatibility between the Province's constitutional jurisdiction over, and vested interests in, immigration and population growth, and the federal government's POGG-derived right to provide for the security of the state by having unfettered powers over visitor visa issuances and border control. With both of these policy issues, New Brunswick's pursuit of interests in the India market had applicability and relevance.

In the case of the Province's participation in La Francophonie, a different dynamic is at play that involves more strategic calculations by both Ottawa and Fredericton, namely using New Brunswick's formal participation in La Francophonie to counterbalance Québec's aggressive positioning for foreign policy autonomy to bolster international support for its claims to self-determination and separation from Canada. In this regard, the international policies of New Brunswick are highly unique in comparison to the rest 
of Canada, and offer a cleares picture into how collaborative federal-piovincial telations can be employed on the international fiont to accomplish international, and domestic, interests

Within each of these policy areas, the following three elements a1e examined
a) New Biunswick's interests,
b) Federal interests, and
c) Policy intersections and collaborative mechanisms

At the heart of this policy by policy examınation of New Brunswick's international interests is the goal of reinforcing the following three assertions made in Chapter 1

a) New Brunswick's International Strategy is not an implementable strategy, but rather a re-expression of status quo activities for action prionties reported as successfully implemented, and outright failure for action prionties that have not been reported on,

b) Despite the Province's attempts at engaging cooperation with the federal government due to its small size many of the actions undertaken aie ad hoc and (ultımately) of very little ielevance to the stated objectives of the International Strategy, but nonetheless can be seen as contributing to a renewal of provincebuilding, and 
c) That some of what the Province does internationally can be more accurdely understood and evaluated as actions designed to protect the Province's intergoveinmental and juisdictional interests and pursue the objective of province-burlding tather than as a strategy per se

With these introductory thoughts expressed, attention is now turned to aforementioned three elements of the International Strategy

\section{Trade Promotion and Investment Attraction}

This section on trade promotion and investment attraction is divided into three subsections The first deals with New Brunswick's interests as they relate to trade and investment 1ssues, each of which is considered in stand-alone sections The second provides an overview of the federal government's interests as they relate to the same The third sub-section examines ways that both orders of government work together to pursue common objectives.

\section{Provincial Interests}

New Biunswick's economic development interests 1equire it to engage in the piomotion of foreign trade, attraction of foreign disect investment (FDI) to the Province, and encouraging inwards technology transfer from abroad Sometımes this involves unilateral 
actıon, in other tımes it means working in partneıship with the federal government ${ }^{374}$ Douglas Biown notes that the Canadian model of fedesal and provincial international engagement is unique in its "degree of involvement of its provinces in the formation of external trade polıcy. ${ }^{375}$ This bifurcated approach is significant because provincial and federal interests do not always alıgn, and since New Brunswick lacks the financial clout to "go it alone" like larger provinces such as Ontarı and Québec, it must either bend 1ts policies to align with its federal counterparts (voluntarily or involuntarily), o1 find a way to act in a unilateral fashion.

\section{Investment}

Investment attraction is one of BNB's most significant and high profile functions. In a province plagued with high unemployment levels; regional economic development disparity between north and south and rural and urban areas; and continued difficulties in traditional natural resource-based industries, the challenge of job creation and wealth generation is taken seriously. In this sense, New Brunswick's investment attraction interests are predominantly aligned to job creation (with special economic incentives available for businesses that establish operations in northern and rural areas) and increasing the total dollar value of Foreign Direct Investment (FDI) into the Province.

374 For example, in BNB's 2003-4 Annual Report, the section on annual highlights notes, "During the period of review, BNB continued to forge strategic, collaborative relationships among all partners: governments (federal, provincial and municipal); businesses, communities; universities; and other research and learning institutions." BNB, Annual Report 2003-4: 11.

375 Douglas M. Brown, "The Evolving Role of the Provinces in Canada-U.S. Trade Relations," in Douglas M. Brown, Early H. Fry, (eds), States and Provinces in the International Economy, Calıfornia, Institute of Governmental Studies, 1993 93, 
The International Strategy (as mentioned in the latter pages of Chapter 3) notes the following investment orlented objective (as part of the 58 "action priorities."

\begin{tabular}{|l|l|}
\hline $1 .:$ & $\begin{array}{l}\text { Pursue new international investment into the } \\
\text { province consistent with our Prosperity Plan targets. }\end{array}$ \\
\hline
\end{tabular}

During the 2002-2003 Fiscal Year, ${ }^{376}$ BNB reported that the number of investment leads identified and pursued was 915 , which translated into the creation of 128 active projects which resulted in 12 projects successfully closed resulting in 812 new jobs being created through seven outside investment projects and 490 new jobs being created through five in-province expansions of companies with operations already existing in the province. Markets in which investment prospecting took place included the northeast United States (Boston, New York), mid-Atlantic United States, California, Texas, Toronto, Germany, Austria and the United Kingdom. ${ }^{377}$

As part of the International Strategy's goal of diversifying inward investment attraction efforts there was an expectation that the Province's economic prospectus would seek out opportunities in new geographic markets. This emphasis on exploring opportunities in new and emerging markets was reflected in a 2005 speech by then Minister of International Trade Minister Jim Peterson, 
Canada must take the need for global competitiveness seriously as we confiont the ise of new economic powers, especially the BRICs [Brazil, Russia, India and China] For established players, the rise of new economic powers is a double-edged sword of promise and piedicamentand for Canada, the challenge is real. But we cannot turn inwards and hope the world goes away. ${ }^{378}$

In the Department's 2006-2007 Annual Report, ${ }^{379}$ however, it was evident that little had changed over several years during which time the Province sought to diversify and grow 1ts investment attraction strategy vis-à-v1s 1ts International Strategy and Prosperity Plan, not to mention the federal government's exhortation for Canadian players to explote new markets. By comparison to the 2002-2003 Annual Report, the 2006-2007 Annual Report also noted that the total number of leads for the year was 1,326 (561 of which were qualified and pursued), resulting in 58 projects and 10 successfully announced projects. No total jobs created figure was provided. Moreover, the Report noted that key markets in which investment was sought included central Canada, Massachusetts, Delaware, Maryland, New Jersey, New York, Pennsylvanıa, Washıngton (DC), Calıfornıa, Texas, Germany, France, Austria, the UK and India. ${ }^{380}$

When considered in the light of the International Strategy's assertion that markets such as the United States; La Francophonie; Asıa (w1th emphasis on Japan and China); the United Kingdom; Germany; Mexıco; and Eastern Europe would have an increased prominence in the Province's new approach to global markets, it becomes apparent that

378 Notes for An Address by the Honourable Ilm Peterson, Minuster of International Trade, to the Canadian Association of Importers and Exporters, $74^{\text {th }}$ Annual Conference, Trade Show and Gala, Toronto, October 24, 2005.

379 Business New Brunswick, Annual Report 2006-2007.

380 Busmess New Brunsw1ck, Annual Report 2006-2007, p. 27. 
BNB's investment attraction efforts focused largely on the US with some attention to Germany, France and the UK, a departure from the earhes assertion of emphasis on Austria and India.

While other departments may play a role in developing projects with some return on investment for New Brunswick in the foreign markets identified in the International Strategy, it is telling that the lead economic development ministry opted to pursue investment attraction opportunities in well-trodden markets of comfort in the several years directly following public release of the International Strategy, namely the United States. The significance of this disjuncture is that it demonstrates a division between the government's preferred policy objectives and how the bureaucracy chose to pursue its own direction, but in light of the government's decision not seek new money for the implementation of the International Strategy's desire to explore new markets, BNB's pursuit of the status quo is understandable. In the absence of an estimate on jobs created, 1t also becomes apparent that the increase in New Brunswick's FDI intake was negligible, suggestıng that New Brunswick's strategic policy positioning on investment attraction had a marginal effect at best.

The means by which FDI is pursued by the Province of New Brunswick has not substantially changed either, with the majority of emphasis placed on marketing the province's "value propositions" such as: low labour and operatıng costs in comparıson to other North American locations; low land and bullding costs, financial incentıves, tax credits and customized packages; 1deal geographic situation conducive to accessing 
north/east North American markets and low workforce attrition rates. The Province regularly flaunts its status as a cost efficient and geographically advantageous North American location in its marketing materials, as well as third party analyses such as those produced by firms such as KPMG. ${ }^{381}$ As suggested earlier though, such selling propositions are neither unique nor novel to New Brunswick, and are employed by regional government jurisdictions across Canada (such as Nova Scotia, Ontario and Manitoba), North America (Massachusetts, Ohio and Arizona), and around the world (Wales, England, Northern Ireland, Singapore, Germany, Philippines). ${ }^{382}$

While a wide range of information related to trade (geographic and product) is publiclyaccessible from Industry Canada's on-line trade statistics website, ${ }^{383}$ the same cannot be said for the availability of landed FDI to New Brunswick. The reasons for this are multifaceted, and depend heavily on different academic and governmental interpretations as to what constitutes the real value of incoming FDI to provincial jurisdictions, as opposed to the overall Canadian impact. The significance of this shortcoming is that the lack of investment attraction performance indicators makes it very difficult to measure the impact of the International Strategy and determine the success or failure of initiatives undertaken by the provincial government. Business intelligence on what companies are doing in particular provincial jurisdictions is notoriously difficult to find. In the case of

381 ACOA News Release citing 2004 KPMG Competitive Alternatives Study, "Canada Most Cost-Competitive of G-7 Countries- Three Atlantic Canadian Cities Rank in Top Five Internationally," February 20, 2004. URL: http://mediaroom.acoaapeca.gc.ca/e/media/press/press.shtml?2774, Accessed: June 17, 2007.

382 Interview with Anonymous Deputy Minister, Fredericton, May 29, 2008. These jurisdictions were mentioned in light of their aggressive marketing efforts in sectoral and geographic markets in which New Brunswick has pursued opportunities.

383 Industry Canada, see URL: http://www.ic.gc.ca/eic/site/cis-sic.nsf/eng/home, Accessed: December 2008. 
New Brunswick, new foreign investment to the province is measured in terms of jobs created in eligible sectors and total volume of inbound invested capital, information that Is avarlable through public announcements ${ }^{384}$ Moreover, measurement of FDI based on job creation announcements made in the media can be inaccurate. Politicians, in the effort to convey positive job creation messages to the public and media, tend to maximize (1.e. exaggerate) workforce creation numbers by announcing the total number of jobs expected to be created over multi-year business ramp-up periods Given, however, that over 3 to 5 years a company's hiring plans can be affected by changes in the economy or business plan), New Brunswick's tendency to use public announcement of job creation creates unreliable reported statistics

A Conference Board of Canada study ${ }^{385}$ that examıned Atlantıc Canada's ability to attract FDI points out that even the most fundamental key performance indicators used to gauge a province's ability to attract foreign investment depends on establishing the distinction between new or "greenfield" investments and Mergers and Acquisitions (M\&A) investments. In 1ts review of various studies on the impact of FDI, the study pointed out that research in the field had falled to,

384 For example, as part of a high-profile provincial involvement in the re-opening of a shuttered mill in Nackawic, New Brunswick, the Province took a proactive role in facilitating the joint acquisition of the asset by India-based Aditya Birla Group of Companies and the Québec forestry product company Tembec. "Business New Brunswick Minister Peter Mesheau announced today that the Government of New Brunswick has signed an agreement of purchase and sale with A V. Nackawic Inc., a Birla/Tembec company, for the assets of the St. Anne-Nackawic mill. This agreement is the next step in the ongoing process to reopen the facility after 1ts closure Sept. 14, 2004." Business New Brunswick, News Release, "Province Signs Agreement for St. Anne-Nackawic Mill," August 3, 2005.

385 Conference Board of Canada, The Employment Effects of Foreign Direct Investment in Atlantic Canada, February 2008. 
Distinguish between $\mathrm{M} \& \mathrm{~A}$ and greenfield investment $\mathrm{A}$ common practice for the new owners of a firm after a merger or acquisition is to streamline the existing operation, resulting in job losses. Thus, since M\&A activity accounts for the majority of FDI, this type of situation is clouding the results. ${ }^{386}$

Given that the Province tracks job creation announcements as indicative of investment attraction but does not differentiate between whether investments are from international (outside Canada), domestic (withın Canada) or internal (within New Brunswick) sources, it is difficult to determine how much FDI flows to NB from foreign sources. Rather, the Province chooses to report FDI by categorization of investments as coming from outside or inside New Brunswick, and correlating the effect of those investments on job (positional employment) creation. But this doesn't really measure the impact of international investment attraction strategies at all.

True measurements of FDI flows are further obfuscated by the tendency of various jurisdictions to count the acquisition of a domestic company by a foreign one as an influx of foreign investment. In fact, the opposite intended effect is normally the case, as foreign takeovers of domestic companies often result in the downsizing of the acquired corporate target. The following table demonstrates the number of jobs created in the years spanning the design and implementation of the Internatıonal Strategy and percentage of change from year to year.

386 Conference Board of Canada, The Employment Effects of Foretgn Direct Investment in Atlantic Canada, February 2008, p. 13. 


\begin{tabular}{|l|l|l|}
\hline $\begin{array}{l}\text { Jobs Created from } \\
\text { Investment }\end{array}$ & Outside $\begin{array}{r}\text { Table 12 } \\
\text { (non-NB) }\end{array}$ \\
\hline $\begin{array}{l}\text { Fiscal } \\
\text { Year }\end{array}$ & Jobs created & \% change \\
\hline $2001-2$ & 410 & \\
\hline $2002-3$ & 812 & 495 \\
\hline $2003-4$ & 741 & -8.75 \\
\hline $2004-5$ & 1,891 & $155.2 \%$ \\
\hline $2005-6$ & 860 & -545 \\
\hline $2006-7$ & 607 & -29.5 \\
\hline $2007-8$ & 797 & 313 \\
\hline
\end{tabular}

On a cumulative basıs, the table demonstrates that in spite of having a renewed strategic commitment to diversifying New Brunswick's investment attraction agenda and two notable increases in job creation in 202-3 and 2004-5, the Province has enjoyed a flat to negative rate inbound FDI growth on a year to year average. This suggests that from an investment perspective, the International Strategy and Prosperity Plan's goal of stımulatıng job creation from internatıonal sources has not transpired.

From the perspective of diversifying where in the world that investment leads onginate from, and how they are approached, the International Strategy's goal of tapping into investment opportunities in jurisdictions other than the United States also went largely unfulfilled, as demonstrated by the table below which conveys information on global investments to New Brunswick from 2000 to 2007 This suggests that the New Brunswick International Strategy did not have a substantial impact in the quality, quantity

387 Business New Brunswick, Annual Report 2001-2002 to Annual Report 20072008. 
or origin of how trade and investment leads are generated, ttacked, implemented and translate into job announcements

\begin{tabular}{|l|l|l|}
\hline \multicolumn{2}{|c|}{ Table 13 } \\
\hline \multicolumn{2}{|c|}{ Global Investment to New Brunswick (2000-2007) } \\
\hline Country of Orgin & $\begin{array}{l}\text { Number of } \\
\text { Projects }\end{array}$ & Asset Value (\$000) \\
\hline Belgıum & 1 & C \\
\hline Bermuda & 3 & C \\
\hline Cyprus & 2 & C \\
\hline Czech Republic & 1 & C \\
\hline Finland & 1 & C \\
\hline France & 3 & C \\
\hline Germany & 1 & C \\
\hline India & 1 & C \\
\hline Ireland & 1 & C \\
\hline New Zealand & 1 & C \\
\hline Nigeria & 1 & C \\
\hline China & 1 & C \\
\hline Singapore & 1 & C \\
\hline Spain & 1 & C \\
\hline Sweden & 1 & C \\
\hline Switzerland & 1 & C \\
\hline United Kingdom & 5 & 10,812 \\
\hline United States & 25 & 628,756 \\
\hline TOTAL & 51 & $2,732,591$ \\
\hline${ }^{\circ}$ C = Confidential & \\
\hline
\end{tabular}

To conclude this section, some of the key indicators with respect to New Brunswick's abrilty to attract FDI demonstrate that the International Strategy did not bring about the 
jesults sought Moreover upon closer examination the methodology used by BNB to t1ack total jobs created, its main key performance indicator with respect to measuring FDI, 1s unieliable and inaccurate The following section deals with New Biunswick's tuade promotion policies, and examines the extent to which the International Stiategy sought to transform New Brunswick's trade selations in an age of globalization

Befole doing so, however, it could be argued that indeed government programs can be poorly focused, measuned and evaluated, and that government often takes credit for change that is conelated with but not the di1ect result of a specific government policy or practice, which in part is reflective of incrementalism Is this simply how government opetates? Certainly this section has demonstrated this is tiue in the case of New Brunswick That said, the confluence of the International Strategy's introduction, newlyelected Lord administration, and relatively new importance accorded to international policy afforded the Government of New Brunswick the opportunity to start afresh and avoid some of these customary and ineffective behaviors of government in general

It is on this basis that this dissertation takes the failures of government to task

\section{Trade}

On the trade side, the Province has a vested interest in assisting companies explore international opportunities for the exportation of pioducts and services thiough facilitatıng business-to-business and intergovernmental networking, training, business 
plan development; participation in trade shows, conferences and sourcing forums; recruitment for trade missions; and provision of market qualıfication advice and intelligence. This export promotion function is a natural one for provinces, McNiven and Cann observe that "By far, the most important Canadian provincial international concern relates to economic development. ${ }^{1389}$ With respect to trade and export targets established in the International Strategy, action priorities that were identified for implementation that relate to the diversification of where business would be pursued include:

\begin{tabular}{|r|l|}
\hline 2. & $\begin{array}{l}\text { Pursue Integrated Trade Strategy with increased } \\
\text { focus on Designated Target Markets. }\end{array}$ \\
\hline 8. & $\begin{array}{l}\text { Focus the presence of New Brunswick's investment } \\
\text { and trade officers in the designated target markets. }\end{array}$ \\
\hline 11. & $\begin{array}{l}\text { Seek new trade and investment markets within La } \\
\text { Francophonie. }\end{array}$ \\
\hline
\end{tabular}

As with the search for FDI, The Province's goal of diversifying where New Brunswick businesses prospect for trade and export opportunities involved looking at markets other than the United States. By looking to orient trade towards the Designated Target Markets, direct trade and investment officers towards those markets, and seek opportunities in markets of La Francophonie, New Brunswick sought to diversify and grow its range of global partners. However, as we see from the following two tables the New Brunswick government has not always met these objectives.

389 James D. McNiven, Dianna Cann, "Canadian Provincial Trade Offices in the United States," in Fry, Brown (eds.), The Expanding Role of State and Local Governments in U.S. Foreign Affairs, 1993: 168. McNiven and Cann note that while most provincial offices in the United States were on ginally envisaged as trade promotion offices, they eventually became more involved in FDI attraction efforts and tourism promotion. p. 172. 
From 2001 to 2003, an approximate average of $89 \%$ of New Brunswick's total exports went to the United States. The following chart provides a snap-shot on where New Brunswick companies exported to in this three year period leading up to the implementation of the province's International Strategy.

\begin{tabular}{|c|c|c|c|c|}
\hline New Bruin & swick s Glo & bal Trading & Partners 2 & 012003 ( $\$$ thousands) $14^{390}$ \\
\hline 3. & 2001 & 2002 & 2003 & $\%$ of multi-year total trade \\
\hline United States & $7,433,851$ & $7,376,966$ & $7,620,546$ & 89 \\
\hline Wapan & 174,568 & 197,035 & 147,381 & \\
\hline $\begin{array}{l}\text { Whited } \\
\text { Kingdom }\end{array}$ & 80,319 & 117,470 & 100,954 & \\
\hline Gerinany & 58,757 & 54,151 & 66,752 & \\
\hline India & 17,624 & 28,461 & 55,926 & \\
\hline Brazi & 67,698 & 55,450 & 47,421 & 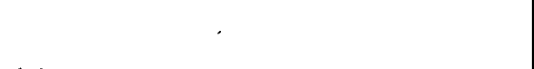 \\
\hline Whina & 20,676 & 26,003 & 42,834 & 11 \\
\hline Spain & 39,756 & 31,802 & 42,354 & \\
\hline Korea, South & 29,450 & 31,286 & 39,207 & \\
\hline Belgium & 55,348 & 58,721 & 38,453 & \\
\hline Subtotal & $7,978,047$ & $7,977,345$ & $8,201,827$ & \\
\hline Others & 373,409 & 291,737 & 371,909 & \\
\hline Countres) & $8,351,456$ & $8,269,082$ & $8,573,736$ & 100 \\
\hline
\end{tabular}

In the 2005 to 2007 timeframe following the International Strategy, the total volume of trade from New Brunswick to the United States increased to $89.5 \%$ of all trade, while non-US trade actually decreased to $10.5 \%$; demonstrating that the goal of diversifying the Province's range of geographic trade partners had not been reached. While on the

390 Industry Canada, http://www.ic.gc.ca; Report Date: September 11, 2008. 
bright side the overall value of exports had increased, sharp escalations in the price of natural resources, commodities and energy exports are argued to have been the catalyst for those higher volumes In retıospect, the Assistant Deputy Minister iesponsible for development of the International Strategy notes that,

From a trade diversification perspective, the New Brunswick International Strategy had no impact, as it did not change our trade partners. It should be noted, though, that the Francophonie statistics do not count our cooperative developmental activities, as trade and export statistics report on the movement of raw product, and exclude almost entirely the export of our soft knowledge and expertise ..our mattères gris. ${ }^{391}$

The inability to measure this soft knowledge and expertıse, despite its obvious value and significance to New Brunswick, was raised with this Assistant Deputy Minıster as well as others in IGA as a shortcoming to the way economic development success and farlure is determined, to which it was noted that performance measurement metrics simply did not exist, and that economic drivers such as technology transfer, commercialization of knowledge and trade in professional services were nearly impossible to track in hard numbers.

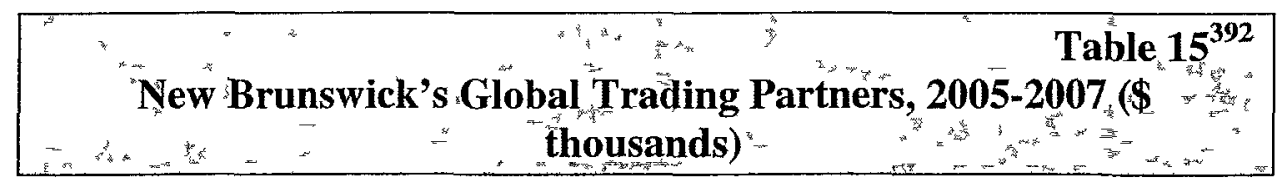

391 Interview with Mirelle Cyr, Assistant Deputy Minister, Francophonie and International Relations, Department of Intergovernmental Affarrs, Province of New Brunswick, January 14, 2009 It should be clarified that New Brunswick's trade volume data does not include trade-in-services data for any geographıc regıon, not just the Francophonie

392 Industry Canada, http.//www.ic.gc.ca; Report Date: September 11, 2008. 


\begin{tabular}{|c|c|c|c|c|}
\hline Vis & 2005 & 2006 & 2007 & $\begin{array}{l}\text { o of nulti } \\
\text { year total } \\
\text { trade }\end{array}$ \\
\hline Wnited States & $9,706,272$ & $9,373,080$ & $9,840,706$ & 89.5 \\
\hline Belgilun & 68,364 & 54,244 & 114,321 & \multirow{11}{*}{10.5} \\
\hline $\begin{array}{l}\text { United } \\
\text { Kingdon }\end{array}$ & 73,524 & 59,675 & 82,983 & \\
\hline Spain & 19,825 & 23,285 & 81,435 & \\
\hline Japan & 88,465 & 55,413 & 68,579 & \\
\hline Brazil & 53,530 & 67,054 & 67,938 & \\
\hline Inda & 49,035 & 57,653 & 65,399 & \\
\hline Netherlands & 80,972 & 7,905 & 52,617 & \\
\hline Romania & 7,573 & 45,502 & 49,334 & \\
\hline China & 20,102 & 36,621 & 48,483 & \\
\hline Sub-total & $10,167,663$ & $9,780,431$ & $10,471,795$ & \\
\hline Others & 555,196 & 628,477 & 709,327 & \\
\hline $\begin{array}{l}\text { Total (Al } \\
\text { Countries) }\end{array}$ & $10,722,859$ & $10,408,908$ & $11,181,122$ & 100 \\
\hline
\end{tabular}

Clearly, New Brunswick's failure to diversify where it engaged in trade was accompanied by the failure to also diversify what it traded.

New Brunswick's Prosperity Plan laid down the Province's objective of transforming economic activity concentration away from extracted raw natural resources and towards value-added products, information technology and its related enabled-services (IT-ES), and other innovative goods. It notes "Our export mix was, and continues to be, dominated by resource-based commodities such as petroleum, paper, wood, woodpulp and fish, while some of the fastest growing Canadian exports during the same time were higher value-added products including pharmaceuticals, furniture, plastics, electrical machinery, 
aircraft and technical instruments." 393 The International Strategy builds on the sentiment, noting that "Expanding trade and the number of exporting firms is essential. The province's Integrated Trade Strategy, which was cancelled shortly after the International Strategy was released, is founded on this direction and on the need to increase the contribution of the knowledge sector and add more value to existing resource-based products through greater cooperation and collaboration between the Province, federal government, private sector and regional economic development organizations."394

The following two tables demonstrate that little substantive change in major exported commodities was realized from 2001-3 to 2005-7 despite the Province's goal of a "diversified market base and sector product lines."395

\begin{tabular}{|c|c|c|c|}
\hline 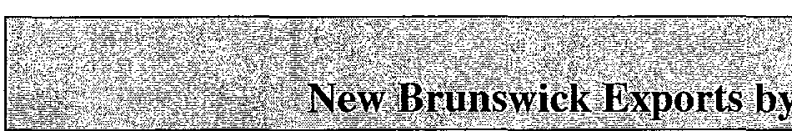 & Product & housands) & Table 16 \\
\hline 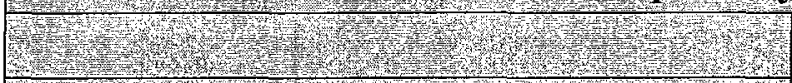 & 2001 & 2002 & 2003 \\
\hline $\begin{array}{l}\text { Light Petroleum OilPreparations (Including } \\
\text { Gasoline) }\end{array}$ & -- & $1,873,360$ & $2,156,221$ \\
\hline Heavy Petroleum OilPreparations & -- & $1,203,673$ & $1,442,013$ \\
\hline Lumber ( 6 minn) & 582,670 & 510,386 & 431,518 \\
\hline bighweightedper & -- & 321,171 & 372,161 \\
\hline Searood IISH Prodicts & 680,707 & 702,408 & 638,101 \\
\hline Newsprint & 231,576 & 231,037 & 207,283 \\
\hline Hotatoes Erozen & 120,875 & 152,949 & 180,876 \\
\hline Electrical Energy & 247,043 & 165,368 & 168,673 \\
\hline
\end{tabular}

$393 \quad$ Province of New Brunswick, Prosperity Plan, 2002: 12.

394 Province of New Brunswick, International Strategy, 2003a: 12. The Integrated Trade Strategy was reported obsolete shortly after publication of the International Strategy.

395 PNB, 2003a: 11.

396 Industry Canada, http://www.ic.gc.ca; Report Date: September 12, 2008. 


\begin{tabular}{|c|c|c|c|}
\hline Chemical Woodpulps (various) & 388,172 & 395,923 & 389,609 \\
\hline Paper Ene & -- & 206,269 & 150,199 \\
\hline Builders Joinery and (Garpentry of & 63,997 & 79,314 & 106,914 \\
\hline Particleboards OSB. Waferboards & -- & 36,064 & 98,043 \\
\hline Petroleum Bitumen & 68,266 & 62,759 & 97,494 \\
\hline Hquefed Petroleun, Hydro & 84,622 & 87,138 & 87,576 \\
\hline Wood Articles & 67,214 & 82,102 & 84,212 \\
\hline Zine Ore and concentrates & 88,790 & 78,403 & 75,557 \\
\hline Semi Chemical Fluting Pap & -- & 87,526 & 63,494 \\
\hline Potassium Chloride & 76,328 & 74,149 & 56,858 \\
\hline Subtotal & $2,700,259$ & $6,349,999$ & $6,806,831$ \\
\hline Others & $5,277,787$ & $1,627,346$ & $1,394,995$ \\
\hline Total (All Products) & $7,978,047$ & $7,977,345$ & $8,201,826$ \\
\hline
\end{tabular}

In the years that followed, note that few changes are evident in the export blend.

\begin{tabular}{|c|c|c|c|}
\hline New Brunswick Exp & orts by Produc & (S thousa & Table $17^{307}$ \\
\hline A. & 2005 & 2006 & 2007 \\
\hline $\begin{array}{l}\text { Wight Petroleum O1 Preparatio } \\
\text { (ncluding Gasoline) }\end{array}$ & $3,448,957$ & $3,172,841$ & $3,358,484$ \\
\hline Heav yetruleum Oil Preparat & $2,387,001$ & $2,276,175$ & $2,930,775$ \\
\hline Limber $(>6 \operatorname{mm})$ & 485,689 & 364,820 & 296,385 \\
\hline Paper Bine & 306,288 & 258,163 & 281,740 \\
\hline Zine Ote and Concenirates & 112,736 & 181,158 & 276,410 \\
\hline $\begin{array}{l}\text { Iiquefied Petroleum, Hydrocarbo } \\
\text { Gases }\end{array}$ & 184,608 & 195,611 & 218,085 \\
\hline Semi Chemieal Woodpulp & 72,347 & 132,901 & 191,335 \\
\hline Petroleum Bitumen & 98,140 & 157,441 & 183,486 \\
\hline Seafood, Fish Product & 617,111 & 620,792 & 512,025 \\
\hline Etassium Chloride & 146,724 & 138,531 & 173,654 \\
\hline
\end{tabular}




\begin{tabular}{|l|l|l|l|}
\hline Lightwe1ght Paper & 58,280 & 276,747 & 166,735 \\
\hline Potatoes- Frozen & 149,791 & 138,693 & 144,808 \\
\hline Chemical Woodpulps (various) & 169,297 & 213,907 & 221,782 \\
\hline Newsprint & 135,225 & 127,505 & 136,477 \\
\hline Electrical Energy & 235,959 & 131,860 & 110,856 \\
\hline Semi-ChemicalFluting Paper & 65,818 & 68,011 & 89,196 \\
\hline Lead (various) & 71,497 & 90,799 & 168,774 \\
\hline Peat & 69,142 & 72,793 & 76,953 \\
\hline $\begin{array}{l}\text { Bulders Jornery and Carpentry of } \\
\text { Wood }\end{array}$ & 160,418 & 154,209 & 76,891 \\
\hline Sub-total & $8,975,026$ & $8,772,957$ & $9,614,850$ \\
\hline Others & $1,747,832$ & $1,635,950$ & $1,566,271$ \\
\hline Total (All Products) & $10,722,859$ & $10,408,907$ & $11,181,121$ \\
\hline
\end{tabular}

A quick scan of these two tables shows that from 2001 to 2007, the export mix remained heavily onented towards extracted natural resources and refined petroleum products, with firm figures regardıng trade-in-services impossible to quantıfy Savoie provides historical and retrospective perspective on the matter, notıng that although similar reforms ${ }^{398}$ were attempted durıng the McKenna admınıstration from 1987 to 1997,

New Brunswick was not very successful in making a transition away from resource-based activities It was able to strengthen its position in the Canadian market in pulp and paper products, lumber, sawmill and other wood products, machinery and equipment and in non-metallic mineral products But it lost ground in retall services, forestry products, wholesale services and personal and miscellaneous services ${ }^{399}$

398 In this respect, it appears that the International Strategy was yet another project in a long series of economic diversification projects

399 Savoie, Pullıng Against Gravity, 2001158 
To summarize, the Province's International Strategy called for an evolution (if not transformation) in the way that investment and trade activities would be pursued in the context of globalization and scholarly reassurances that regional governments in federations have a role to play on the world stage. However, there is little evidence that these objectives were reached or that patterns were changed in any substantive way. With this examination of the Province's efforts in the trade and investment in hand, the following section looks at the Government of Canada's interests.

\section{Federal Interests}

This section provides insight into how the federal government pursues its international commercial interests, a critically important function to which New Brunswick officials pay close attention. The Government of Canada takes the wider view that it plays a central role in the promotion and pursuit of the country's macroscopic trade and investment objectives, and pursues economic development interests in ways that are complementary and overlapping with the provinces. Some of those activities include: actively promoting Canada as a cost efficient and safe place in which multinational corporations can establish or relocate operating facilities; promotion of two-way trade with Canadian partners; facilitating Ministerial and other senior level missions to international markets (such as erstwhile Team Canada missions); hosting inbound missions to Canada by foreign delegations; negotiation of international agreements, MOUs and treaties pertaining to bilateral and multilateral economic relations; 
development, negotiation (with the provinces) and implementation of trade policy and representation of Canadian interests in trade dispute adjudication. ${ }^{400}$

To pursue these objectives the federal government attempts to synchronize the activities of a range of central agencies, line departments and Crown Corporations including: DFAIT, Industry Canada, CIC and ACOA. For the most part, however, the International Trade section of DFAIT handles the majority of Canada's projection of economic development interests worldwide. Financial instruments that are leveraged by the federal government to promote trade and investment objectives include the Business Development Bank of Canada (BDC); Export Development Corporation (EDC); and the Commercial Credit Corporation (CCC). Additionally, a wide range of other ministries are engaged on an as-needed basis, including: Human Resources Development Canada (HRDC), Agriculture Canada, Environment, Fisheries and Oceans, the Privy Council and PMO.

From a jurisdictional angle, section 132 of the Constitution of Canada gives jurisdiction over regional economic development to the provinces. ${ }^{401}$ Keeping in mind the federal

400 The last two items are sole federal jurisdiction, but are done in consultation with representatives of the Province's Trade Policy Division of IGA.

401 In his examination of the treaty-making powers of Canadian provinces, Mathieu Roy, Treaty-Making Powers of Canadian Provinces: Revisiting the 1960s Debate in Light of Subsidiarity and Federal Loyalty, Master's Thesis, Graduate Department of Law, University of Toronto, 2005, advances the notion that provinces should have more autonomy in the field of external affairs, and that treaty limitations as established in the Constitution are paternalistic, incorrect, and should therefore be modified. He cites Patry in J. Brossard, A. Patry, and E. Weiner, Les pouvoir éxteriurs de Québec, Montreal: Les Presses de l'Université de Montreal, 1967: 87. 'En réalité, il n'est plus admissible que les États members de federations ne puissant négocier et signer eux-mêmes les conventions qui les intéressent directement en tant qui collectivités autonomes, et qu'ils 
power to enter into foreign treaties and agreements and the need to keep federal action away from being deemed ultra vires (outside of jurisdiction) as was the case during the JCPC hearings of the 1930s, Ottawa has entered into a multitude of international agreements oriented towards the promotion of Canada's international commercial interests over the past several decades, the goal of which is to create an environment in which Canada's commercial interests can be advanced. Officials at IGA who requested anonymity, however, raise questions regarding the extent to which the federal government should be leading versus supporting provincial efforts to stimulate economic growth in the provinces, especially in areas that are consistent with provincial economic development objectives.

But in the area of promoting Canada and by extension New Brunswick's economic interests, how is the federal government to proceed when the province lacks the financial and marketing clout to go it alone? Should the federal government be concerned with the promotion of all of Canada as a collective and inclusive federation, or should it take into consideration special factors that influence the small, poor and dependent regional governments and jurisdictions? At what point should the federal government recognize the differences between big and small provinces through the extension of asymmetric methods of engagement? These are important questions to New Brunswick, and factor high into Provincial undertakings such as working and Minister-led missions to foreign markets; pursuit of commercial interests; and articulation of region-specific policies and initiatives.

ne soient point habiles à participer par leurs propres représentants aux conferences internationals de fins qui sont, par leur nature, de resort exclusive des états fédéres." p. 2 
One way that the Government of Canada promotes the nation's economic interests is to become a member and signatory to a wide range of organizations, agreements and associations that facilitate its trade and investment objectives. Such agreements help create a positive or proactive environment in which commercial relations between companies located in each jurisdiction can deal with and relate to one another, as well as have recourse to reparative mechanisms and processes where disputes may occur (such as violations of balance of payment obligations, adherence to intellectual property regulations, imposition of trade or investment-related barriers or tariffs, or compliance with other regulatory requirements). Skogstad, for example, discusses how the Government of Canada leverages collaborative relations with the provincial governments to not only negotiate international trade agreements, as well as develop highly institutionalized mechanisms (such as CTRADE) through which those interactions can transpire. ${ }^{402}$

From a global perspective Canada is involved with the: World Trade Organization (WTO), International Monetary Fund (IMF), World Bank, Asia-Pacific Economic Cooperation Council (APEC), La Francophonie, the G8, and Organization for Economic Cooperation and Development (OECD). Within North America, Canada entered into the Canada-U.S. Free Trade Agreement (FTA) with the US, which evolved into the North American Free Trade Agreement (NAFTA). On the investment attraction front the federal government is signatory to a range of Foreign Investment Protection Agreements 402 Grace Skogstad, "International Trade Policy and Canadian Federalism: A Constructive Tension?," Canadian Federalism: Performance, Effectiveness, and Legitimacy, 2002. Also see Christopher John Kukucha, Duane Bratt, (eds.), Readings in Canadian Foreign Policy: Classic Debates and New Ideas, Toronto: Oxford University Press, 2006: 226. 
(FIPAs), other (than North America) Free Trade Agreements and bilateral and multilateral agreements in areas such as Science and Technology that have a bearing on inbound and outbound investments.

Lest it be thought that the federal government enters into these agreements on a unilateral, non-consultative manner, Ottawa actively solicits provincial input into proposed and desired agreements pertaining to development and implementation of, for example, trade agreements. The annual report of the Trade Policy division of the New Brunswick Department of Intergovernmental Affairs suggests that regular quarterly meetings between federal and provincial government international trade officials helps ensure that discussions and negotiations remain institutionalized, and ensure that intergovernmental dialogue continues to take place,

Via quarterly meetings of federal-provincial/territorial officials responsible for International Trade Policy, DIIR represented the views of New Brunswick stakeholders to the Chief negotiators for Canada on various international trade and investment agreements, i.e., the WTO fisheries subsidies; Canada's improved offer in the on-going Services negotiations; the future of NAFTA; Canada's relationship with emerging markets; potential Free Trade Agreement with Korea; the Canada-EU Trade and Investment Enhancement Agreement. ${ }^{403}$

While it proved impossible to obtain further comment on the effectiveness of these discussions on the record in the form of an interview, officials that have been associated with these sorts of $\mathrm{F} / \mathrm{P} / \mathrm{T}$ vehicles have candidly stated that quarterly meetings are largely ceremonial and perfunctory events designed to perpetuate the notion that effective 
intergovernmental meetings are taking place in a dynamic, back-and-forth fashion. What the outside observer doesn't see, it is noted, is the typical modus operandi where provinces come to the table with self-interested concerns that they attempt to negotiate with the federal government that do not get resolved at the multilateral negotiation table, and a federal government whose primary interest seems to be presenting numerous reports, "powerpoint" presentations and statistics on how effective their representation of Canada's interests are. Instead, it was noted, the most effective process by which intergovernmental dialogue takes place is on a one-to-one basis in a non-institutionalized environment, as the inter-bureaucratic mechanisms described here play a role best described as symbolic and ineffectual.

\section{Bureaucratic Organization}

Ottawa's role in promoting trade and investment opportunities abroad (in a manner that serves the needs of all provinces whether large or small) requires an accurate understanding of the bureaucratic organization and structuring of federal missions abroad, as well as familiarity with the organizational and institutional channels through which market information, intelligence and opportunities are generated abroad and transferred to provincial governments for their further pursuit. While formal and informal dialogue between political and intergovernmental officials may perfunctorily lend support to the notion that federal government services and institutions serve all Canadians, in reality those functions may be inherently geared (intentionally or unintentionally) to the large provinces. While the federal government is within its rights 
to prospect for, generate and qualify investment or trade opportunities for Canadian companies, it should work collaboratively with the provinces in light of the concurrent nature of federal and provincial interests in the area of economic development.

DFAIT can be understood as a two-way swinging door to Canada's global economic interests, swinging outwards to promote Canadian exports to international markets, and inwards to attract FDI. On the trade promotion side, the federal government attempts to stimulate Canadian exports to foreign markets through services provided by the Canadian Trade Commissioner Service (TCS) division of DFAIT. Trade Commissioners located in posts and missions around the world also provide services related to the inwards investment attraction function.

The TCS is headquartered in Ottawa with offices in major commercial centres around the world in countries of significance to Canada's commercial interests. The TCS helps Canadian businesses do business outside of Canada by assisting them: a) prepare for international markets; b) assess market potential; c) find qualified contacts; and d) resolve problems. ${ }^{404}$ The federal government also provides Canadian businesses with access to online resources that identify and quantify potential business opportunities, such as the Virtual Trade Commissioner (VTC) service.

404 See http://www.tradecommissioner.gc.ca/eng/home.jsp, Accessed: December 2008. For a critical view of the TCS modus operandi, see Gene Swimmer, How Ottawa Spends, 1997-98: Seeing Red, A Liberal Report Card, Montreal: McGill-Queen's Press, 1997: 122-123. 
In the case of promoting FDI flows into Canada, the federal government uses its Invest in

Canada initiative to help companjes considering business expansion to or within North America consider Canada as an investment destination of choice. ${ }^{405}$ In most cases, Trade Commissioners posted abroad are responsible for generating and qualifying trade and investment attraction leads, which in turn are transmitted to headquarters and the provinces for further pursuit. The other objective of the Invest in Canada initiative is to develop and disseminate marketing intelligence on why Canada is an ideal international location for multi-national corporations to establish operating facilities. ${ }^{406}$ From an interinstitutional linkage perspective, the Invest in Canada initiative has been leveraged by the DFAIT as a means to synchronize federal and provincial efforts at attracting FDI through education, a point discussed in the following section dealing with collaborative mechanisms.

405 See http://www.investincanada.gc.ca/eng/default.aspx, Accessed: December 2008.

406 The federal government (and to some extent the provinces by extrapolation) has been called to task over its promotion of outward flow of products and services (exports) and inwards attraction of FDI, while giving short shrift to promoting increased importation of goods and services and outwards flow of investment. At the 2006 World Outsourcing Forum hosted at the University of New Brunswick, for example, former BNB Minister Norm Betts noted that this tendency has the net effect of preventing New Brunswick from integrating itself into global value chains (GVCs) and related valueadded processes, as well as gaining valuable beach heads in other markets through the establishment of foreign investments. In Betts' estimation, both Ottawa and Fredericton had fallen prey to the seductive tendency of pursuing surplus balance of trade and investment attraction. While both have the net effect of demonstrating positive economic growth, they do so in a manner that precludes New Brunswick's integration into international production and manufacturing processes that rely on the inwards flow of goods and services, as well as establishment of foreign investments that demonstrate to the opposite jurisdiction a willingness to encourage mutual economic development, an example of which is McCain Foods' US \$14.6 million frozen foods packaging facility in north-western India in 2005. See "McCain Foods to Build Potato Processing Plant,"Frozen Food Digest, July 1, 2005. 
Case Example: Canada's Mission in India

While understanding Canadian foreign policy is an important consideration related to this examination of New Brunswick's international policies, Canadian foreign policy administration is an area that is less known to provinces such as New Brunswick. The significance of this gap relates closely to New Brunswick International Strategy process, in that when the province seeks federal partnership in exploring international opportunities, be they in the areas of immigration attraction, trade and investment promotion, educational partnerships or intergovernmental partnerships and agreements, knowing how decisions are made, policies are developed and human/financial resources are deployed are of importance.

In the case of small provinces like New Brunswick this knowledge is especially relevant given the strong need to work in cooperation and leverage services of the federal government through headquarters and foreign posts and missions abroad. Given the importance of India to New Brunswick's international activities despite the fact that it was not identified as a priority market in the International Strategy, the following pages discuss how the Canadian government pursues commercial interests in India, and proceed to discuss how this information is relevant to the Province.

From a policy coordination perspective, as the federal government continually develops and modifies its prospectus on engaging the world, decisions are made on which geographic regions to focus efforts. While issues of significance will arise related to 
Canada's interests in all regions of the world, in the effort to rationalize and justify targeted efforts, the federal government since the early 2000s has evolved its BRIC (Brazil-Russia-India-China) approach, and has sought the input of the provinces in shaping and developing Canada's global commercial interests. Through F/P/T consultations on the development of the federal government's Global Commerce Strategy (GCS) in 2002, DFAIT sought and obtained feedback from the provinces on issues they felt should be reflected in Canada's engagement of the world.

As part of this new federal strategy, new resources became available for pursuit of greater political and economic engagement of Canada-India relations in light of India's rapid rate of growth, and strong bilateral relations underpinned by strong immigration trending, economic relations (originating with agro-fertilizer exports to India during its Green Revolution in the 1960s), and shared experience as former colonies of the British Empire and members of the Commonwealth. At mission headquarters in Delhi, political and diplomatic relations are managed by the High Commissioner, while economic development matters are handled by the Senior Trade Commissioner (STC) through the head of mission office in Delhi and commercial offices in other major business hubs such as Mumbai, Bangalore, Chennai, Hyderabad and so forth. While the High Commissioner and STC work collaboratively, the STC leads the work of Trade Commissioners (comprised of Canadian-originated officers as well as locally-engaged staff) engaged in trade and investment promotion in particular sectors and/or geographic areas. Leads and opportunities that are identified and qualified through research, company calls and 
generation of strategic market intelligence then flow from the post to Headquarters and the regional trade offices, discussed later.

Since the advent of the BRIC approach to focussing Canada's international commercial strategies, India has been a destination of choice for the trade and investment promotion efforts of nearly all provincial governments, with the most active being Ontario, Alberta, Québec and British Columbia. These provinces have deployed Premier-led missions to market, as well as engaged in hiring on-the-ground consultants, entered into co-location agreements with the federal government or established stand-alone offices.

To support the activities of provincial government officials, the India mission provides mission planning, organization and execution support, as well as facilitation of meetings, prior to which (in most cases) the post would request that the visiting jurisdiction complete a Business Mission Agreement (BMA) which would provide a notional overview of the nature and intention of the incoming mission. The India mission also generates and disseminates news and business media information for wide $\mathrm{F} / \mathrm{P} / \mathrm{T}$ audiences through Infoflow, a regular electronically-distributed information service provided to federal and provincial government officials that is comprised of news summaries from domestic media sources as well as notifications of upcoming events, agreements and studies. Given the amount of dignitary-level travel to India from other jurisdictions around the world, where elected members and other senior members of the executive cadre seek to meet their governmental counterparts DFAIT encourages that 
provinces work directly with the Canadian mission in India to organize government-togovernment meetings so that federal involvement is not circumvented.

In order to establish the connection between this federal commitment to the India commercial market and the provinces, the next few paragraphs overview how the federal government facilitated New Brunswick's international interests while also advancing the Atlantic region's collective interests and the India commitment as per DFAIT's Global Commerce Strategy. As part of the development of the GCS and reorientation of Canada's commercial policy, a new emphasis was placed on building two-way economic relations with India in the early 2000s. Large provinces such as Ontario, ${ }^{407}$ Alberta, Québec and British Columbia were quick to send Premier and Minister-led delegations to market to pump up bilateral trade volumes and support federal FDI promotion efforts; smaller provinces such as New Brunswick were nowhere to be seen in those markets as the result of scant resources, lack of market awareness, lack of commercial interests in those markets and greater comfort with pursuing opportunities in the United States.

ACOA and the New Brunswick DFAIT office sought to promote Atlantic Canada's participation in exploring trade and investment opportunities in India. To support this costly undertaking, three Atlantic Provinces entered into a federal-provincial cost-sharing program to participate in the 2008 National Association of Software and Services Companies (NASSCOM) Leadership Summit taking place in Mumbai, India in February

407 For example, the Province of Ontario along with the Canada-India Business Council (C-IBC) undertook a mission to India from February 4-13, 2003 to explore trade opportunities in the area of infrastructure-oriented goods and services. http://www.ontarioexportsinc.com. Accessed: June 2007. 
2008 As a result of the partneiship between the Provinces of New Biunswick, PEI and Newfoundland, ACOA's regional office, and DFAIT, the federal government provided 70 percent funding to the provinces' thiee way split of the remaining 30 percent of costs associated with on-site matchmaking services for the purposes of 1dentifying leads for investment attiaction activities In this case ACOA's customized appioach for dealing with Atlantıc Canada's dımınıshed capacity to partıcıpate in market exploratıon actıvitıes in India resulted in New Brunswick being able to pursue opportunities in areas such as creatıng partnerships with Indian outsourcers lookıng to establish near-shore operatıng facilities in North America and companies lookıng to establish advanced manufacturing facilities within easy reach of the United States market This region-specific initiative led to New Brunswick's decision to follow-up the trip with an ongoing commitment to exploring commercial relations opportunities in India, and by extension, the value of such asymmetric and region-specific initiatives.

Polıcy Intersections and Collaboratıve Mechantsms

Given that both the federal and provincial government have overlapping interests in economic development, both must work with one another From a macroscopic perspective, it appears that on issues related to intergovernmental collaboration between both orders of government, there is a good level of policy integration, commitment to collaborative federalısm, and desire to limit friction points Indeed, Hale and Kukucha cast light on the increasing rate of federal-provincial investment and trade policy integration in Canada, arguing that, "A significant side effect of these policy shifts has 
been the evolution of federal-provincial policy cooperation that accommodates both the ongoing integration of Canada's varied regional economies in North America and provincial participation in shaping federal trade policies and rules within an overall framework of federal leadership." 408 This complementary approach, they believe, is based on the federal and provincial government's pursuing interests in a way that enables them to "accommodate significant differences in regional economic interests in responding to economic change rather than pursuing a 'zero-sum' politics of dominance and dependence.,"409

In many cases, these intersections bring Canada's international trade policy undertakings into areas of provincial jurisdiction. For example, with the focus of Canadian trade policy moving away from tariffs imposed on agricultural and manufactured goods and towards service sectors, questions arise with respect to the province's jurisdiction to engage in policy implementation. Vengroff and Rich note that, "[...] most trade treaties now go well beyond tariffs; they focus on items such as intellectual property, trade in services and investment. Many of these recent international trade agenda items fall squarely within provincial jurisdiction in Canada." ${ }^{410}$ New Brunswick's International Strategy professes to be cognizant of these overlaps, and outlines a number of action priorities that aim to maximize the power of collaboration and intergovernmental cooperation. The following action priorities contained in the Strategy purport to:

408 Geoffrey Hale, Christopher Kukucha, "Investment, Trade, and Growth: Multilevel Regulatory Regimes in Canada," in Bruce Doern, Robert Johnson, (eds.), Rules, Rules, Rules, Rules: Multilevel Regulatory Governance, Toronto, University of Toronto Press, 2006: 180 .

409 Hale and Kukucha, "Investment, Trade, and Growth," 2006: 181.

410 Vengroff and Rich, "Foreign Policy by Other Means," 2006: 111. 


\begin{tabular}{|r|l|}
\hline 3. & $\begin{array}{l}\text { Strengthen our partnership with the federal } \\
\text { government in pursuing our investment and trade } \\
\text { nterests. }\end{array}$ \\
\hline 5 & $\begin{array}{l}\text { Work with the federal government to enhance the } \\
\text { movement of people, goods and services across the } \\
\text { New Brunswick/Mane border through infrastructure } \\
\text { improvement and risk management programs. }\end{array}$ \\
\hline 6 & $\begin{array}{l}\text { Enhance our corporate approach to participating in } \\
\text { Team Canada and Team Canada Atlantic trade } \\
\text { missions in close partnership with our business and } \\
\text { academic community. }\end{array}$ \\
\hline 12. & $\begin{array}{l}\text { Host an International Business Symposium in the fall } \\
\text { of 2003 bringing together international experts, } \\
\text { business and key federal and provincial agencies. }\end{array}$ \\
\hline
\end{tabular}

But few of the action priorities noted above constitute a new way for the Province to pursue new trade and investment efforts, nor do they constitute an appreciable deviation from, or augmentation to, status quo activities pursued by Business New Brunswick. Economic interactions with the State of Maine have transpired for many decades previous to the International Strategy, and even recent innovations to the Canada-US border crossing have either happened before or independent of the Strategy goals.

As an example, the NEXUS initiative was a joint Canada-United States central government undertaking to provide Canadian and US travelers with a fast access ID card to facilitate rapid border crossings as part of the broader commitment to the Western Hemisphere Travel Initiative (WHTI), and as such, had little to do with provincial jurisdiction. There is no evidence suggesting that the International Strategy influenced that process; Department of Transportation officials would convey the results of their work with the ISWG from time to time, but there was no meaningful interplay between IGA's "implementation" of the International Strategy and DOT's pursuit of 
infrastructural improvements to New Brunswick- Maine border crossings. Nevertheless, there are significant connection points between both orders of government in this policy domain. The following sections examine some ways in which the Province and federal government have attempted to work in collaboration and in accordance with Canada's system of federalism by looking at initiatives such as: the Federal/Provincial/Territorial Co-location Program, Atlantic Trade and Investment Partnership, Promotion Agreement, Trade Team New Brunswick, CTRADE, Trade Team New Brunswick, and shared training initiatives.

Federal/Provincial/Territorial Co-location Program

The F/P/T co-location program is another mechanism by which the federal government attempts, for its part, to incorporate the participation of the regional governments into its missions abroad within the diplomatic envelope. Under this scheme, provinces are able to establish their own presence in a given post or mission abroad through the deployment of a provincial government representative into an office located within the respective mission. The individual occupying that position would have access to a physical office within the mission, communications architecture, administrative assistance from post staff and the other normal amenities provided to regular federal diplomatic staff. As per the Memoranda of Understanding (MOU) signed between the federal and provincial governments, provincial governments agree that situating their officials within a federal mission abroad includes recognizing the over-arching authority of the Canadian Head of Mission (HOM). 
During a 1998 debate over provincial representation at Canadian embassies in the House of Commons, the Liberal government of the day noted that their experience with the program to that point had shown that,

Co-locating provincial staff within Canadian missions abroad provides for a closer co-ordination and a better sharing of the workload between federal and provincial officials that is likely to occur between a Canadian embassy and a separate provincial government office. Co-locations make optimal use of scarce resources and reflect the team Canada spirit. ${ }^{411}$

This type of extra-territorial representation has been attempted in the past by New Brunswick, such as its effort to establish an Atlantic Provinces office in London in 1958. This attempt failed. Bringing us back to the Chapter 1 assertion that small size is a significant factor in the analysis of Canadian provinces' external affairs policies, Hilliker observes that while the Province of Manitoba opened its own office in London in 1964, it closed it shortly thereafter in 1965 . "Recognizing that a smaller province was in difficulty competing with Ontario and Quebec, the Premier concluded that trade promotion was better left to Ottawa." ${ }^{, 412}$ New Brunswick did consider opening a dedicated provincial office in Paris to support its activities within La Francophonie, with Premier Louis Robichaud taking up the matter with Prime Minister Pearson. Although Pearson and Robichaud settled on an agreement for New Brunswick to create a provincial office within the Paris office of the Canadian mission in France, and the Province officially

411 House of Commons Debates, September 21, 1998, p. 8176, cited in Donald M. McRae, The Canadian Yearbook of International Law, Canada: UBC Press, 1998: 374375.

412 Hilliker, 1995: 321. 
named J.-Gérard Degrâce as its representative, the project never materialized. ${ }^{413}$ And as indicated in the section dealing with New Brunswick's trade promotion efforts, it did open and subsequently close a mission in the Boston consulate office.

The benefits of this initiative are that it allows provincial representatives to pursue the interests of their respective jurisdiction from within the Canadian mission; liaise closely with federal diplomatic and economic development officers; gain high levels of commercial intelligence under the Canada "brand;" and attain top-level access to relationships likely otherwise not available to regional orders of government. In India for example, provinces such as Ontario, Quebec, Alberta and British Columbia have taken part in this program at various points in time.

The major downside for the Government of New Brunswick, however, is that the buy-in price for a co-location is approximately $\$ 250,000$ to $\$ 300,000$ per year, excluding staff salary, expenses, relocation costs and other ad hoc and incidental expenses. While various Deputy Ministers have gazed longingly at the initiative, they realize that the inordinate cost of the opportunity, its inherent value notwithstanding, makes it prohibitive for the Province. One also suspects that despite the benefits that participation in this scheme could offer, it may elicit a skeptical or incredulous reaction from a largely rural

413 See Benoît Bourque, La Participation du Nouveau-Brunswick dans la naissance et le développment de la Francophonie, Travail présenté à Monsieur Michel Tétu, director d'essai et professeur à la faculté des Lettres, Maîtrise en relations internationales, Université Laval, 4 novembre 2000. 
New Brunswick population, resulting in potential loss of political support ${ }^{4 / 4}$ In the words of one former Deputy Minıste1 who had consideted the benefits of the piogram,

It would be ideal if we could set up a New Biunswick representative in a foreign market that we can't access as easily as the United States Problem 1S, who's got the cash to fund 1t? The feds have the bar set pretty high for small governments like ours, and I can't rationalize that kind of draw on my budget whether it be worth it or not ${ }^{415}$

The high cost associated with this initrative allows larger provinces to participate in it much more easily and pending the particular internatıonal orientations of the government of the day, whereas it remains inaccessible to smaller provinces of lesser human and financial means While the issue has been ratsed with DFAIT in ad hoc and formal intergovernmental communications, the standard response from officials has been that the program runs on a cost-recovery basis, and that discretion to subsidize some provinces' participation in the co-location program has implications that would have to be reckoned with at the highest bureaucratic and political levels given the costs involved As some like Savoie and Thorburn might argue, the politics of supplication are thusly manifested in the unequal access to federal economic development initiatives by smaller, economically-dependent provinces

414 This particular aspect of New Brunswick's political culture 1s mentioned in greater detail in Chapter 5

415 Anonymous, Interview with Deputy Minister, January 2006 
Atlantic Trade and Investment Partnership (ATIP)

The Atlantic Trade and Investment Partnership (ATIP) was signed by the four Atlantic Canadian provincial governments and the federal government in 2002 as a five year initiative whose goal is to assist Atlantic Canada realize greater success in the areas of international trade and investment attraction. Upon examination, however, despite the date of its inception and overt raison d'être of promoting meaningful intergovernmental collaboration on extraterritorial commercial relations, the ATIP initiative appears unrelated to the Prosperity Plan and New Brunswick's International Strategy, and seems to have evolved separately from the International Strategy process. The ATIP was organized on the principle that ACOA should work in conjunction with private sector, academia, provincial government departments and other federal departments to promote Atlantic Canada's export economy and location as a desirable location for the attraction of FDI. According to ACOA, ${ }^{416}$ the ATIP is comprised of the following elements:

- Team Canada Atlantic missions: offer export-ready Atlantic Canadian businesses the training, partnerships and connections they need to successfully enter international markets, particularly those in the United States and other strategic markets.

- Sector Export Strategies: support the assessment of export opportunities and the implementation of export development strategies for specific industry sectors.

416 ACOA, URL: http://www.acoa-apeca.gc.ca; Website, Accessed: January 2009. 
- Trade Education and Skills Development: enhances trade awareness and competencies of small and medium enterprises and provides the necessary tools to help them increase their export activity.

- Export Internship for Trade Graduates: provides employment opportunities for international trade graduates and offers in-house expertise to businesses wanting to capitalize on international markets.

- Atlantic Investment Strategy: accelerates investment research, awareness and promotion activities that internationally position Atlantic Canada as a profitable place to do business.

\section{Trade Team New Brunswick (TTNB)}

Trade Team New Brunswick was developed during the early years of the Lord administration (1999-2006) as a mechanism with which to coordinate federal, provincial and local level entities within the province having mandates related to promotion of exports. Some of the main features of this partnership include: increased interorganizational dialogue; skills development for companies; and promoting coordination between strategic planning and trade activity. Members of this initiative include Federal/Provincial organizations such as: ACOA, Agriculture Canada, BNB, Export Development Corporation (EDC), DFAIT and the New Brunswick Enterprise Network. ${ }^{417}$ Like the ATIP, however, examination of the (scant) material regarding

417 The New Brunswick Enterprise Network was created on July 18, 2002 and was jointly announced by federal Minister of Labour Claudette Bradshaw and BNB Minister Norm Betts. The goal of the 15 Enterprise Agencies located throughout the province was to synergize efforts between municipal, provincial and regional orders of government in 
TTNB revealed no obvious connection between its creation and the Province's International Strategy.

The significance of this policy-practice disconnect has dire implications. From the perspective of ensuring horizontal policy consistency within the provincial government, it is evident that there is little connection between the International Strategy and what government departments were actually doing. From a vertical policy consistency perspective, there appeared to be little by way of a relationship between prescribed policy and its translation into what government "did." But why the disjuncture?

While it proved impossible to get anyone from BNB to comment on the question of why provincial trade promotion and investment attraction efforts were virtually uninformed by the International Strategy, the fact that the strategy was unsupported by a stand-alone budget approved by the Board of Management committee of Cabinet spoke volumes. Indeed, why should BNB alter its policies for "IGA's International Strategy?" Why should the "silo" approach be jettisoned for the sake of broad-based goals that pulled BNB away from its own mandate and objectives?

the area of local economic development. For more information see ACOA, News Release, "15 Community Economic Development Agencies in New Brunswick Unveil as Enterprise Network," July 18, 2002. As a joint federal-provincial announcement, the creation of the Enterprise Network was the result of major contributions from both orders of government in order to stimulate grassroots economic development as well as harmonization of federal, provincial and local strategic interests, labour force training and mobilization, business capacity-building and inter-organizational coordination. 
CTRADE

CTRADE ${ }^{418}$ recognizes the generally-accepted constitutional legitimacy of provincial international activity, and creates an environment in which trade and intergovernmental officials from both orders of government can meet on a regular basis to discuss issues such as Canada's negotiation and implementation of international trade agreements, which in turn provides valuable regional government perspective on the local impact of federal policy.

New Brunswick has been an active and cooperative member of this intergovernmental forum, and has endeavoured to clearly articulate its own areas of international interest in recent times. When the Trade Policy unit of the Government of New Brunswick was housed within Business New Brunswick, that department noted,

The Federal Government, through the Minister responsible for International Trade, is responsible for representing Canada's interests in international trade negotiations. However, it has been the tradition since 1985 that the provinces are consulted on an on-going basis with respect to matters concerning international trade policy. The Minister of Business New Brunswick represents the trade interests of New Brunswickers to the Government of Canada. ${ }^{419}$

418 Few Canadian scholars have dedicated as much attention to the issue of provincial governmental activity in the area of international trade within the context of Canadian federalism as has Christopher Kukucha. For more information, see "Domestic Politics and Canadian Foreign Trade Policy: Intrusive Interdependence, The WTO and the NAFTA," Canadian Foreign Policy, Vol. 10, No. 2, Winter 2003; and "The FederalProvincial Committee System on International Trade: CTRADE - An Extension of Executive Federalism?," in an anticipated collection by Luc Bernier, Nelson Michaud, (eds.), The Administration of Foreign Affairs: A Renewed Challenge?, Toronto, University of Toronto Press, forthcoming.

419 Business New Brunswick, "International Trade," 2003. 
Post-release of the International Strategy, the Trade Policy division was moved to IGA ${ }^{420}$ in order to coordinate and integrate policy development related to international affairs. Since then, the Trade Policy division has leveraged its membership to CTRADE to partake in discussions affecting New Brunswick stakeholders such as ongoing WTO fisheries subsidies, Free Trade discussions within NAFTA and other trade blocs such as Central America, and various investment promotion agreements. The significance of moving Trade Policy to IGA is noteworthy, in that it is consistent with the government's desire to bring a degree of centralization and coordination to the way New Brunswick works with the federal government on commercial development policy areas of shared jurisdiction.

\section{Team Canada Atlantic}

Team Canada Atlantic (TCA) is a federal-provincial initiative that involves partnership between ACOA and the four Atlantic Provinces, along with support from DFAIT, Agriculture Canada, Industry Canada and other federal departments on an as-needed basis. Initiated in 1998 under the Council of Atlantic Premiers (CAP), the TCA initiative was a regional expression of federal government's commitment to the larger-scale Team Canada missions that scoured the world for international opportunities to promote Canadian trade and investment objectives. In this case, however, outbound TCA

\footnotetext{
$420 \quad$ "New Brunswick's International Strategy recognizes the federal government's jurisdiction over Canada's international affairs, treaty ratification, and trade policy, and that New Brunswick's success in the global community is inherently tied to Canada's success on the international stage." IGA, Annual Report 2004-2005, 16-17.
} 
missions' exclusive focus exclusive is scoping opportunities in the United States, ${ }^{421}$ and are geared towards promoting the commercial interests of small to medium sized enterprises (SMEs) versus larger business interests, a focus that is apropos given the prevalence of smaller-sized business in New Brunswick and Atlantic Canada.

Despite the benefits brought by the TCA, neither New Brunswick nor any of the other Atlantic provinces can afford to keep it operating without the extension of federal funding. Vengroff and Rich cite the federal Treasury Board of Canada Secretariat's estimate that from 1999-2006, approximately $\$ 4.1$ million was spent on TCA missions, ${ }^{422}$ of which the federal government contributes $60 \%$, with the remaining $40 \%$ divided between the four Atlantic Provinces. As of early 2009, the Pan Atlantic Cooperation Agreement on International Business Development Agreement (IBDA) through which federal dollars flow from Ottawa's coffers to the TCA program will expire, and to date the agreement has not been renegotiated or renewed.

421 The Team Canada Atlantic website notes that since its inception, missions have been undertaken to New England, New York, Atlanta, Washington D.C., Chicago and Florida. The same site also provides testimonials from New Brunswick companies, suggesting that the increased profile offered by this initiative help regional SMEs identify opportunities to expand their business. Horizon Mouldings' VP and CEO Pierre Côté notes, "I had taken part in U.S. trade shows in the past and had made initial contacts with Boston area companies. The Boston TCA trade mission allowed me to meet one-on-one with these contacts and to solidify the relationships I had with them. I also met with other potential clients, including large retailers and distributors, and finalized an agreement with one of those distributors." URL: http://www.teamcanadaatlantic.com. Accessed: February 10, 2009.

422 Vergroff and Rich, 2006: 129. 


\section{Shared Training}

The federal government offers a series of courses to DFAIT officers (and other federal officials) on investment promotion best practices, the first of which is called Investment (INV) 101, followed by INV 102, 201, etc... The goal of these courses is, from a human resource capacity-building perspective, to better prepare federal government employees to appreciate and consider Canada's FDI attraction goals through knowledge building on subjects such as lead generation and qualification, market intelligence, client outcalls, the strategic planning, maximizing the use of missions abroad, leveraging the Canada "brand" in international marketing initiatives, and so forth. "Students" from provincial bureaucracies tasked with economic development (investment) promotion receive notification of course availability through electronic notifications from a federal portal attached with the Invest in Canada initiative.

Provinces are regularly kept abreast of the INV course calendar and are welcome to enroll on a non-cost recovery basis, with the Province of New Brunswick regularly sending its investment officials to the courses. In addition to promoting inter-institutional linkages through joint education, federal government international marketing officials convene with their provincial counterparts on an annual basis to share best practices, discuss issues of mutual concern and air differences.

While the International Strategy notes the need for training provincial staff in order to increase their capacity and competency for international work, it is significant to note that 
inclusion of provincial government officials into the Invest in Canada training modules is not a consequence of New Brunswick's Inteinational Strategy, nor were follow-up commercial skills-training initiatives initiated For example, to facilitate greater awareness of the cultural and social differences between major cultures, religions and peoples from around the world among provincial government officials, the New Brunswick Department of IGA and Office of Human Resources worked in conjunction with the Canadian Foretgn Service Institute (CFSI) and DFAIT to include federal curriculum on cultivation of intercultural awareness into the provincial human resources course offerings as a class titled "Intercultural Effectiveness Training Progiam" The International Strategy called for the addition of "international diplomacy and competencies as one of the training services offered to companies preparing to export," however, the training was only provided to provincial government officials and on a single occasion ${ }^{423}$

The course was delivered to representatives from the Departments of Education, PostSecondary Education, BNB, IGA, Office of Human Resources, Fisheries and Finance on March 28-29, 2007 While the training provided benefit for the Province from a human resource capacity-building capacity, it did not result in any appreciable strengthening provincial companies' ability to work effectively and in an increased culturally-effective manner in world markets, thereby signifying yet another farlure in the ability of the Province to implement its International Strategy

423 Province of New Brunswick, 200322 The following action prionty, however, was fulfilled by the adoption of this federal training module- "Adopt 'international competencies' as part of its core competencies requirement for Executıve Development and Advancement" 
Some issues related to New Brunswick's bilingualism were reflected in the delivery of the Intercultural Effectiveness Training Program. Given that New Brunswick is an officially bilingual jurisdiction, as is the Government of Canada, it is standard policy to ensure that all training opportunities are: a) delivered with simultaneous, side-by-side translation; b) delivered in parallel English and French languages sessions; or c) presented in one language or the other with bilingual facilitation and participant interaction.

As such, during the planning phase of this initiative IGA received and propagated concerns that the pilot course was to be conducted in English (with bilingual facilitation), and would use in the market case studies jurisdictions such as China, India and Latin America, markets where use of English was prevalent. Given that New Brunswick French language interests (related to the work of, for example, francophone immigration attraction efforts, New Brunswick's participation in La Francophonie, and the work being done by the five French campuses of the New Brunswick Community College (NBCC) in the sale of proprietary training and skills development courseware in developing international markets) were more relevant to discussion of markets such as western Africa and Europe, internal consultations suggested that a better approach would be to offer the two courses separately.

As a small province, however, the challenge of offering provincial officials this training in both official languages was fraught with difficulties. First, given IGA's role in coordinating the training and its role in coordinating the Province's Official Languages 
Act, the issue could not avoid being politically-charged and politically-sensitized to the point where intra and interdepartmental dialogue on training implementation was difficult (according to a participant who insisted on absolute anonymity). Second, as a small province New Brunswick was challenged to pay for the training twice since while the CFSI owned the curriculum and was willing to make it available to New Brunswick, it did so on a cost-recovery basis. On a third point, related to the second, while the Province had officials that sought to benefit from the training opportunity, they lacked the critical numbers to justify the financial costs of offering the course twice.

To conclude, the trade promotion and investment attraction portfolios particularly illustrate the complexity of intergovernmental relations between the federal and New Brunswick governments, even when they share common concerns and each order of government is not having their jurisdiction contested. While both the federal and provincial governments work with one another on promotion of commercial interests, New Brunswick's simultaneous dependency on and desired autonomy from the federal government creates a unique relationship.

We will now look to the issue of immigration, and how it particularly illustrates the complexity of shared jurisdiction between the federal and New Brunswick governments, especially given the conflicting objectives of each. As will be demonstrated in this next part of Chapter 4, fragmentation of the federal and provincial governments' interests regarding immigration has resulted in significant dysfunctionalities. 


\section{Immigration}

The challenge of growing and maintaining a sustainable population base has been one of the most pressing challenges for the Province of New Brunswick. The interrelationship between provincial government immigration promotion and the mounting importance of regional governments in international affairs underscores this challenge. Despite the policy intersection between federal and provincial responsibility for immigration as established in the Canadian Constitution, policy-based inter-jurisdictional divergences have thwarted New Brunswick's interests.

As outlined in Chapter 1, New Brunswick is a small province with a highly, rural population. With relatively static population growth that periodically undergoes contraction, New Brunswick's ability to attract and retain new immigrants has been an issue of concern for many years. As the result of these challenges, the International Strategy stated that one of its key objectives was to ensure "increased immigration levels of skilled workers, entrepreneurs, foreign students and researchers," an element of which hinges on the ability of both provincial and federal governments to work together in a collaborative, complementary intergovernmental fashion.

As Canada's only officially-bilingual province, the Province also purports to take active measures to ensure that immigration attraction efforts aim to retain a linguistic balance of 1/3 Francophone and 2/3 Anglophone. 
New Brunswick's difficulties in attracting and retaining a viable population base have had widespread causes such as: negative political attention on successive Liberal and Progressive Conservative administrations; limited growth of the domestic economy vis-àvis diminished workforce; and relative homogeneity of its local communities. The reasons for New Brunswick's less-than-stellar performance in this area are contested and argued, but likely relate to:

- Predominantly rural and bucolic character;

- Lack of high-paying, sustainable employment in traditional resource-based and emerging information technology sectors;

- Relatively weak efforts to promote economic migration while in foreign markets;

- New Brunswick's relatively homogenous ethno-cultural demography;

- Inability to retain immigrants that choose to move to New Brunswick but eventually leave for larger metropolitan and cosmopolitan urban areas; and

- Poor financial backing of settlement and cultural acculturation services at the level of local government.

From a "province-building" perspective, there is a clear connection between the Province's increasingly proactive role in immigration-attraction and Chapter 1's assertion that regional governments are playing a more efficacious role in international relations. This section of the chapter more fully lays out some of the policy-based and interjurisdictional factors underlying New Brunswick's immigration interests. 
Highlighting the importance of this issue, approximately one year after the introduction of the International Strategy (which was preceded by the Prosperity Plan) the leading provincial newspaper called on Premier Lord to adopt tough forward measures to deal with population and immigration related issues. In a tersely-worded editorial, the New Brunswick Telegraph Journal pointed out that the province's population was in serious decline as the result of the simultaneously converging factors of: stagnant immigration attraction efforts, negative birth-to-death population replacement trends and interprovincial out-migration. It was argued that the Province must adopt aggressive measures to grow the population, including aggressive immigrant attraction and retention of foreign students post graduation for the purpose of workforce integration, noting,

Despite it being a have-not province of 1.17 million people, about onethird larger than New Brunswick, Manitoba's Premier Gary Doer is attracting 10 times as many immigrants a year to his province than Premier Lord is to ours. Neither has Mr. Lord made immigration a priority like Nova Scotia's Premier John Hamm, who is expected to soon appoint the country's first provincial minister of immigration. Mr. Lord's Prosperity Plan, like last week's throne speech, sees immigration as merely a way to bring a few hundred investors or skilled workers here each year. We need thousands a year. ${ }^{424}$

As part of the same series of articles outlining some of New Brunswick's main concerns related to immigration, the Telegraph Journal notes,

While the number of people around the world eager to live in Canada is overwhelming, no more than one in 200 newcomers to Canada each year comes to live in New Brunswick. Like all the Atlantic provinces, New Brunswick gets less than its share, compared to its percentage of Canada's population. As they try to counter a looming population decline and severe 
shortage of skilled workers, New Brunswick is trying to attract immigrants. But how does New Brunswick compete with Toronto, a city known the world over? ${ }^{425}$

In response to such criticisms and questions concerning provincial efforts to bolster inwards immigration and consequent augmentation of the population, New Brunswick's International Strategy contained 13 action priorities intended to promote a range of actions such as greater immigration ranging from development of a stand-alone Immigration Strategy, hosting of a provincial immigration conference and working constructively with the federal government. As will be demonstrated in the following pages, despite the introduction of these priorities there was no subsequent population increase.

\section{Provincial Interests}

Immigration to New Brunswick takes place through one of two gateways- federal and provincial. On the provincial side of things, immigrants can be nominated to come to New Brunswick on direct invitation by the Province through the Canada-New Brunswick Provincial Nominees Program (PNP) through one of two streams: job offer or business. In the former instance, a prospective immigrant must have a valid offer of employment in a skills area in which the province has a labour market shortage. In the latter instance, prospective immigrants must have a certain net worth, viable business plan and preliminary site visits to New Brunswick on business visa. The following pages provide greater insight into these and other aspects of New Brunswick's immigration interests.

$425 \quad$ New Brunswick Telegraph-Journal, "Attracting newcomers no easy task," December 8, 2004, p. A1/4. 


\section{Bureaucratic Organization}

The question of "who" within the Government of New Brunswick handles immigration and immigration-related issues was a moving target in the years prior to, during development of, and immediately after New Brunswick's International Strategy. Unlike the federal system where immigration issues are for the most part handled by CIC, the Province subsisted for several years in a game of immigration policy "hot-potato"426 with no one department stepping up and taking responsibility. Prior to changes in the New Brunswick government structure on announced on February 14, 2006, which resulted in the creation of the Immigration and Repatriation Secretariat, the Lord government had resisted calls for the creation of a stand-alone department responsible for handling all aspects of immigration. Prior to February 2006, the following departments exercised jurisdiction over immigration-related issues:

a) BNB- management of the Canada-New Brunswick Provincial Nominees Program (PNP);

b) IGA- policy advocacy with federal government, Francophonie issues;

c) Education- foreign student exchange programs involving inbound students;

426 "Don't be mistaken in thinking that there weren't attempts to centralize the handling of immigration issues by reorganizing government here in New Brunswick. A few years ago the opportunity to have all the immigration components rolled into a unit to be housed at IGA failed. Word is, they thought it was a political hot potato, and they didn't want the province's stagnant population to be an albatross hanging around their neck." Interview, Anonymous, September 2006. 
d) Training and Employment Development- repatriation and retention of expatriot New Brunswickers, labour force and foreign worker education and experiential accreditation evaluation.

e) Wellness, Culture and Sport- Francophone immigration.

The main driver of New Brunswick's immigration involvement was done through the Immigration division of Business New Brunswick. Immigration activities can be broken down into four functions: promotion and attraction, application processing, retention and consultations. While promotion is one of the most important parts of immigration attraction, the Provinces lacks resources to carry out promotional activities, in which case BNB worked closely with third parties such as immigration lawyers and consultants.

Given the economic implications of the PNP, BNB aimed for a mix of skilled workers (40\%) and business plan applications (60\%) in markets such as India and Pakistan (skilled IT sector workers), China and Korea (business plan applications), Germany (business plan applications), and the United Kingdom (mix of skilled workers and business plan applications). In addition to these markets, the Province aimed to attract francophone immigrants to New Brunswick from markets such as France, Belgium, Romania and Lebanon. To attract these immigrants, PNP representatives would employ a range of federal-provincial collaborative mechanisms such as: seminars at the post or mission, one-on-one meetings, trade fairs and provision of materials to the Canadian mission abroad. 
From a processing perspective, the ability of New Brunswick to bring prospective economic immigiants to the province in roughly 8-12 months rather than the normal 3-5 years through Canada's front door makes fast-tracking migration possible Once the Province assesses and recommends an economic migrant for 1mmigiation to New Brunsw1ck, howeve1, from the time stamped papers are sent from New Brunswick to the home country post or mission it is nearly impossible to track when the "nominee" leaves their country and arrives to Canada, as the constitutionally-guaranteed right to internal movement allows all migrants the right to live where they may In 2003 , however, the Province began negotiations with the federal government on a Memoranda of Understanding to access a portion of the federal immigration data bank to determine place of landing and allow for PNP program adminıstratıon evaluation

\section{Facts and Figures}

The following table shows New Brunswick's population growth rate from 1981 to 2006 alongside the Canadian average The percentage of change for the last two Census Canada reportıng periods are indıcated to quantıfy on a percentıle basis the magnitude of change during the years during which New Brunswick's International Strategy was designed and implemented

Population of Canada and New Brunswick

427 Sources Statistics Canada, censuses of population, 1956 to 2006, http //www12 statcan ca/english/census06/analysis/popdwell/ProvTerrl cfm, Accessed September, 2007 


\begin{tabular}{|l|l|l|}
\hline Year & Canada & New Brunswick \\
\hline 1981 & $24,343,000$ & 696,000 \\
\hline 1986 & $25,309,000$ & 709,000 \\
\hline 1991 & $27,297,000$ & 724,000 \\
\hline 1996 & $28,847,000$ & 738,000 \\
\hline $\begin{array}{l}\% \\
\text { Change }\end{array}$ & 402 & -122 \\
\hline 2001 & $30,007,000$ & 729,000 \\
\hline $\begin{array}{l}\% \\
\text { Change }\end{array}$ & 535 & 014 \\
\hline 2006 & $31,613,000$ & 730,000 \\
\hline
\end{tabular}

The International Strategy takes note of this disparity between Canada's positive growth rate and New Brunswick's decline, noting that "The 2001 Statıstics Canada Census Report covering the perrod from 1996 to 2001 shows that New Brunswick's population declined from 738,133 to 729,498, a 12 per cent drop, whereas the overall Canadian population rose from $28,846,761$ to $30,007,094$, an increase of 4 percent " 428 The Conference Board of Canada notes that the challenge of ensurnng robust 1mmigration policies is closely related with demographic changes taking place in Canada, and that the viability of its labour market force is closely related to positive immigration flows It argues, however, that Canada on the whole has missed the mark, arguing,

How successful are we at selecting, settling and integrating the immigrants we value so highly? The answer is that Canada is falling short in many respects Our immigrant selection processes are not ensuring that the best qualified or most needy applicants are selected with all possible speed, with fairness and with full regard to national securty And once they are 
here, we are also not adequately supporting their own efforts to achieve happy and productive lives for themselves and their families. ${ }^{429}$

In addition to the social and economic benefits of positive immigration intake, there are other unconventional consequences. For example, a robust immigration-attraction system can impact on provincial equalization payments. A $1 \%$ decrease of New Brunswick's total population (estimated to be approximately 750,000 ) can influence on the provincial welfare. In 2003-4 dollars, a 1\% decrease would result in the loss of nearly $\$ 20$ million. By 2026, the cumulative loss of federal equalization transfers from the federal government to the Province of New Brunswick would have a total value of over $\$ 685$ million. $^{430}$

The challenge of maintaining and growing New Brunswick's population is one of the most difficult and significant challenges facing the province. The provincial division of the Canadian Broadcasting Corporation (CBC) notes,

[...] New Brunswick needs immigrants now more than ever. Young people are leaving, and those who stay are having fewer children. The rest are simply getting older and costing the system more money. As the population continues to decline, so does the government's ability to raise money to pay for services. The province is bracing for a demographic disaster. Companies complain they can't find enough skilled workers. The health-care system is in desperate need of more doctors and nurses.

Political leaders and visionaries seem to agree that immigration is the

429 Conference Board of Canada, How Can Canada Prosper in Tomorrow's World: Performance and Potential 2004-05, Canada, 2004: 121

430 APEC points out that in comparison to the traditional population, newcomer immigrants have a lower unemployment rate, higher than average median income and lesser reliance on publicly accessible government services. See Atlantic Provinces Economic Council (APEC), Report Card: Nominee Programs Boost Atlantic Immigration, July 2008. 
answer. But they must ask one key question: why are immigrants coming and not staying? ${ }^{431}$

New Brunswick's challenges in attracting immigrants in relation to other provinces are demonstrated from Citizenship and Immigration Canada's immigration statistics in the year before the International Strategy's release. In 2002, CIC showed that New Brunswick received 710 immigrants, which represents approximately $0.31 \%$ of total immigration to Canada. ${ }^{432}$ If New Brunswick was aiming to attract immigrants to the province representative of its population in relation to Canada's total population, that figure should have been approximately 10 times higher- 7,089. The Atlantic Provinces Economic Council (APEC) noted that demographic trends will affect the Atlantic provinces- "Slower population growth and an ageing population will erode the expansion of the labour force and the associated tax base." Moreover, "New Brunswick's population is projected to begin shrinking by 2008 , declining about $3 \%$ by $2026 . " 433$ To the detriment of New Brunswick, that $3 \%$ population decline by 2026 will result in 22,518 less people. In order to compensate for that loss, New Brunswick's total inbound immigration would have to rise to 1,024 per year.

While certain citizenship and immigration related policy issues involve federal jurisdiction, most notably the prerogative to allow or disallow foreigners physical access to Canadian soil, it is worth taking note that the Canada's regional governments are also constitutionally-assigned the right to unilaterally pursue their immigration interests, as

$431 \quad$ Feature news story aired by the Canadian Broadcasting Corporation's New Brunswick outlet, http://nb.cbc.ca/features/perfectstrangers Accessed: April 30, 2004.

432 CIC, 2002: 7.

433 APEC Report, July 2002. 
well as through federal-provincial agreements. Section 95 of the Constitution Act, 1982 establishes the concurrency of the federal and provincial governments to legislate in areas related to immigration policy,

In each Province the Legislature may make Laws in relation to Agriculture in the Province, and to Immigration into the Province; and it is hereby declared that the Parliament of Canada may from Time to Time make Laws in relation to Agriculture in all or any of the Provinces, and to Immigration into all or any of the Provinces; and any Law of the Legislature of a Province relative to Agriculture or to Immigration shall have effect in and for the Province as long and as far only as it is not repugnant to any Act of the Parliament of Canada.

Despite legitimate provincial claims to sharing jurisdiction over immigration, the mandate of the provincial Population Growth Secretariat suggests that while New Brunswick has jurisdiction in visa matters. "In Canada, immigration is a shared responsibility of the Federal and Provincial governments. However, accepting immigrants and issuing visas is done by the Federal Government. This is to ensure national security and integrity in the system." ${ }^{.434}$ This view seems to convey a type of intergovernmental docility and willingness to voluntarily accord to the central government jurisdictional centricity, a view that does not seem to percolate to other provinces of similar size. ${ }^{435}$

\footnotetext{
434 Population Growth Secretariat, http:/www.gnb.ca/Immigration/ immigratingCanada2007-e.asp, Accessed: January 8, 2008.

For example, the Nova Scotia Nominee Program (NSNP) serves a similar function as New Brunswick's PNP, but by contrast notes that "The program is administered by the Nova Scotia Office of Immigration in partnership with Citizenship and Immigration Canada, the federal department responsible for immigration." While nuanced, the difference in tone is evident. NSNP, http://novascotiaimmigration.com/ immigrating-to-nova-scotia, Accessed: September 15, 2009.
} 
With respect to the Province's engagement of external-to-government stakeholders, during consultative meetings of the International Strategy Working Group and external stakeholder forums, benefits of an efficiently managed immigration system were recognized to include: an increasingly globalized and cosmopolitan population; renewed professional, academic and entrepreneurial class; investment capital; and adequate labour supply necessary for expansion of the economy. Immigrants were also observed as being able to serve as a networking, linguistic and cultural bridge to new commercial opportunities for provinces while prospecting in new and emerging markets around the world. Demonstrating the value of relying on the on-the-ground savvy of New Brunswick's ethno-cultural communities, the Department of Intergovernmental Affairs developed a "China Action Plan Stakeholders Group",436 in the Fall of 2006 that included members of the New Brunswick Chinese community as well as representatives of academia, government, private sector and other actors with interests or knowledge of engage China. ${ }^{437}$

436 Development of a series of regional action plans was outlined as a deliverable under New Brunswick's International Strategy.

437 While the final Action Plan was not tabled in the New Brunswick Legislative Assembly, it comprised a de facto model through which the Province's China interests were pursued. Upon the visit to Fredericton of Mr. Lu Shumin, Ambassador of the People's Republic of China to Canada, the Province's goal of developing a China Action Plan was publicly discussed. "With the provincial government's commitment to provide interested Chinese students, teachers and professors with a list of provincial governmentrecognized post-secondary institutions - such as the University of New Brunswick, St. Thomas University and the Maritime Forest Ranger School - New Brunswick hopes to increase the number of those coming into the region. [...] The agreement will answer a number of objectives in the province's developing China Action Plan, which is expected to be unveiled in the fall. The plan is expected to address a variety of international relationship concerns, including investment and immigration." New Brunswick Telegraph Journal, "Province Trying to Attract Chinese Students, Professors," May 20, 2006. 
Given that an ageing workforce and declining population affects New Brunswick's general economic competitiveness, the Department of Business New Brunswick had responsibility for the PNP when the International Strategy was developed. This raised concerns from the multicultural community that the Province viewed immigrants only in terms of their inherent economic worth, and discounted the value of robust and ethnoculturally diverse communities. ${ }^{438}$ During stakeholder meetings such as for China, ethnocultural and immigration/settlement promotion organizations raised serious concerns that the Province failed to consider the holistic value of immigrants, instead preferring to quantify immigration attraction efforts through focussing on skilled and highly trained professionals from abroad.

For example, during a keynote address at the 2004 Rendez-vous Immigration Conference in Saint Andrews, New Brunswick hosted by the provincial government in June 2004 (a deliverable of the International Strategy) Lawrence Solomon ${ }^{439}$ castigated provincial governments who use their powers to nominate prospective immigrants to Canada in favour of inordinate emphasis on highly-skilled professionals. Instead, he argued, regional governments along with the federal government should place a premium on poor and unskilled workers who will actively assume and retain employment opportunities seen as unpalatable for the local population. ${ }^{440}$ Solomon's argument, while controversial,

438 It proved difficult to obtain statements to this effect on the record from members of the multicultural and immigration community given their fear of retribution for publicly criticizing the provincial government's focus on the economic value of immigrants.

439 Also see Lawrence Solomon, "Best Immigration Policy is the Freest," The National Post, November 29, 2005.

440 See Hélène Destrempes, Joe Ruggeri, (eds.), Rendez-Vous Immigration 2004: Immigration in New Brunswick, Issues and Challenges, (Proceedings of a Conference 
was very well received by conference representatives spanning across multicultural and immigrant settlement organizations, government and business participants.

The goal of this conference was to "bring together different sectors of New Brunswick society to promote an awareness of immigration as a valid choice for the province and to establish areas of cooperation between the various stakeholders to make New Brunswick a destination of choice for immigrants."441 Over the two days of the conference, members of New Brunswick's English and French language ethno-cultural organizations presented views to the Province on how a viable, sustainable long-term immigration policy could be developed and implemented.

While the majority of discussions in the break-out committees and plenary sessions appeared to focus on issues surrounding rural and remote settlement difficulties, EnglishFrench disparities in attraction and settlement issues, education, and retention issues, there was a noticeable absence of participation from CIC, Human Resources Development Canada (HRDC) and DFAIT despite widespread calls for: increased openness and transparency in the immigration application processing system, licensed ${ }^{442}$

held in St. Andrew's, New Brunswick, August 2004), Policy Studies Centre/ Atlantic Metropolis Centre, Canada, December 2005.

441 Discussion of Rendez-vous Immigration 2004 Conference in 2004-5 Annual Report of the New Brunswick Department of Intergovernmental and International Relations, p. 29. For more information on the conference proceedings, see Hélène Destrempes, Joe Ruggeri, (eds.), Rendez-vous Immigration 2004: Immigration in New Brunswick Issues and Challenges, Policy Studies Centre, University of New Brunswick, December 2005.

442 The issue of non-licensure for immigration consultancy has been of concern to the Province since the introduction of the Canada-New Brunswick Provincial Nominees Program. As the result of a lack of governmental oversight in this area, civil legal actions have been launched against immigration consultants, such as Yao Shao-Min (Plaintiff) 
immigration consultancy to navigate complicated application and bureaucratic processes, and an apparent lack of intergovernmental coordination between the Province of New Brunswick and the federal government. No reason for the absences was given.

\section{Federal Interests}

Over the course of research conducted in the preparation of this dissertation, several New Brunswick government officials mistakenly stated that the federal government has exclusive jurisdiction over immigration. This position was also expressed during consultations related to the development of the Province's International Strategy and stakeholder negotiations. In fact, immigration is in fact an area of shared jurisdiction with the provinces as established in Section 95 of the Constitution Act, 1867, the Citizenship Act, and Section 8 Immigration and Refugee Protection Act. This section therefore examines the federal government's role in immigration.

For the most part, ${ }^{443}$ the Government of Canada's interests in the area of immigration are managed and pursued by the Department of Citizenship and Immigration Canada (CIC).

and Pierre Rouleau, Paul's Flower Shop Ltd., a body corporate, and Mark Farwell (Defendants), Court of Queen's Bench of New Brunswick, Trial Division, Judicial District of Saint John, Court File No.: S/C/331/07, July 24, 2007. In a second lawsuit against the same consultant, "An immigration consultant working in New Brunswick is facing a second lawsuit from another former client. Pierre Rouleau is a vice-president with KBL International Services Inc., a company that has been helping entrepreneurs from China qualify as immigrants. In documents filed in court in Saint John in August, Mei Ping Sun accuses Rouleau of not living up to his agreement with her." CBC News (New Brunswick), " $2^{\text {nd }}$ Lawsuit Brought Against Immigration Consultant," http://www.cbc.ca/canada/new-brunswick; Accessed: September 2007. 443 Other federal ministries and organizations such as DFAIT, Human Resources Development Canada, the CIDA, Revenue Canada, Service Canada, Transport Canada 
In 2003-4, CIC officers were active in advancing Canada's immigration interests through its headquarters in the National Capital Region in Ottawa and in Canadian posts and missions located abroad. Some of CIC's core interests include:

- Attracting inwards migration through attracting new immigrants through professional, academic, family reunification or humanitarian channels and determination of national annual intake volumes;

- Developing and implementing security clearance processes to manage who is allowed to enter Canada irrespective of regional destination; and

- Managing the citizenship-granting process.

In theory, $\mathrm{CIC}$ recognizes that it cannot work in a unilateral fashion, and must engage stakeholders outside of the federal government. As noted in the Department's 2004 Annual Report, "This means working with a broad range of partners, including federal departments and agencies, provincial and territorial governments, municipalities, community service providers from the voluntary sector, international organizations, foreign governments, researchers and other stakeholders." 444 Nonetheless, given the asymmetrical nature of the division of power between the federal and provincial government in favour of the former by way of its power to unilaterally deny issuance of entry visas to Canada, it is not inaccurate to say that power of immigration determination lies squarely in the federal prerogative.

and the Privy Council Office have direct or indirect interests related to Canada's immigration policy.

444 Citizenship and Immigration Canada, Annual Report to Parliament on Immigration 2004. 
Policy Intersections and Collaborative Mechanisms

The points of overlap between provincial and federal immigration efforts and interests are complicated at best and messy at worst and are compounded by New Brunswick's small size and lack of expendable resources for autonomous immigration attraction efforts, as well as the high rate of exodus of "landed" immigrants. Various other intra and intergovernmental issues with respect to incompatible policy interests and disjointed inter-organizational relations present challenges to the analysis, despite CIC's assurance that it understands that the Constitution accords to provinces the ability to pursue immigration policies consistent with their interests. As noted in the CIC Annual Report for fiscal reporting period 2004-5,

Jurisdiction over immigration is shared between the federal government and the provinces and territories. Ongoing intergovernmental consultation and cooperation are critical aspects of managing the immigration program, related policies and legislative initiatives. ${ }^{445}$

This section examines some of the challenges of these intersections, mechanisms designed to engender collaboration and cooperation and examples of complete breakdown of policy synchronization efforts.

First from a bureaucratic perspective, the organization of federal and provincial immigration-related ministries has been fraught with difficulties. Prior to creation of the Population Growth Secretariat (PGS) on April 1, 2007 (and its subsequent staffing and 445 Citizenship and Immigration Canada, Annual Report to Parliament on Immigration, 2005: 13. 
assignment of budgetaty 1esources) whose 1esponsibllities would include "1mproving and incieasing immigration and settlement seivices to 1etain newcomeis [and] aggressively marketıng New Brunswick as a great destınation to live and work, ${ }^{, 446}$ the P1ovince had no single cohesive government ministry thiough which immigration and population giowth issues could be articulated

Instead, New Brunswick's immigration interests were managed in a disjointed and uncoordınated manner BNB managed the PNP, Post-Secondary Educatıon, Traınıng and Labour (PETL) managed university, college and workforce and traınıng 1ssues, incidental matters were spread between IGA, Education and other departments on an ad hoc basıs, with settlement services handled by municipalities and CSOs As suggested earlier in this section, albeit cited under condition of anonymity, several senior officials with IGA, BNB and Post-Secondary Education noted that in the past, provincial jurisdiction over immigration related issues has been bounced around government such that one official described it as a "policy orphan" IGA passed on the opportunity to house the 1mmigration attraction function within itself in the late 1990s and early 2000s, and BNB limited the inbound immigration function to attraction of skılled labour (to the detriment of settlement, education and retention onented issues), and (most notably with respect to the International Strategy)

Lord, by virtue of his adherence to the conservative ideology that less government is better than more, was resistant to creating a stand-alone department under whose mandate 446 Province of New Brunswick, News Release, Office of the Premier/Business New Brunswick, "New Brunswick to Establish Population Growth Secretarıat," February 16, 2007 
immigration and immigration-related issues could be dealt with in a corporate manner. Nonetheless, on February 14, 2006 the Lord administration announced creation of an Immigration and Repatriation Secretariat that would combine the "immigration components of the Department of Business New Brunswick and the former Department of Training and Employment Development; also, the Repatriation Program from Training and Employment Development." 447

By contrast, the federal government's interests regarding immigration were largely concentrated within the mandate of $\mathrm{CIC}$. As a result of these two diverging organizations, the degree of variance between the mandates and activities of federal and provincial governments resulted in few direct bilateral channels through which intergovernmental dialogue could transpire to facilitate inter-jurisdictional cooperation and collaboration, ironically, even where there appeared to be a genuine willingness to work together.

While final decisions on applicant admissibility are under federal jurisdiction, New Brunswick partakes in regular federal-provincial consultations under the Canada-New Brunswick Letter of Agreement on Immigration, a part of which includes regular intergovernmental meetings on shaping federal immigration policies. Meetings are held both regionally in the Atlantic area, and federally in Ottawa, and New Brunswick specific working groups have been developed in which officials from multiple departments at each order of government as well as local settlement groups and civil society entities are able to dialogue and discuss issues of concern.

447 Office of the Premier, Press Release, "Changes to Cabinet and Departments Aimed at Helping Province Achieve New Goals," February 14, 2006. 
Second, despite the federal government's use of foreign missions to assist the immigiation attraction efforts of all regions and provinces of the country in an equitable fashion irrespective of their territorial, demogiaphic or economic size, ${ }^{448}$ and that use of federal embassies and high commissions for favoured treatment of certain provinces constitutes an improper practice, there are deep-seated suspicions that prospective ımmigiants that approach Canadian missions abroad regarding immigratıng to Canada are discouraged from coming to New Brunswick

In the case of the Canadian Embassy in Paris, a CBC television interview with a recent 1mmigrant to New Brunswick revealed allegations of systemic bias towards promoting francophone 1mmigratıon to Québec and discouragıng prospectıve PNP nomınees from coming to New Brunswick:

I thınk New Brunsw1ck has to be more aggressive as Québec are [s1c]. There is a big problem in Paris, in the [Canadian] Embassy When you go the Embassy in Pans, if you are French...they will say to you to go to the Québec delegation And if you say 'no,' I want to go to New Brunswick, they say 'why?' Go to the Québec delegation. ${ }^{449}$

$448 \quad$ "The Canadian Embassy in France serves as the representative of the Government of Canada to the Government of France. Its role is to represent Canadian interests in France in economic and commercial and cultural fields and, in more general terms, to promote these areas of expertise and excellence to specialized contacts (media, academic, political institutions, corporations) or the general public. [...] The Canadian Embassy in France, moreover, handles procedures for anyone who wishes to apply to go to Canada, either permanently or temporanly (Immigration Division). (Canadian Embassy in France website, “The Embassy's Mission, http.//www.dfa1t-maeci.gc ca/canadaeuropa/france/ ambassade/mission-en.asp, Accessed: September 5, 2003.

449 CBC Radio Broadcast, 2004. While systemic bias of this type was widely alleged by provincial government officials (representing multiple departments) interviewed for the purpose of this dissertation, the challenge of finding other documented or citeable occurrences of bias proved difficult. The reasons for this are likely varied, and related to the unwillingness of provincial government officials to provoke the 1re of federal colleagues whose support is sought and so badly-needed in various policy undertakings. 
Third, under the Canada-New Brunswick Agreement on Provincial Nominees that was signed on February 22, 1999 and amended on March 29, 2005 to become permanent, New Brunswick is permitted to nominate up to 200 individuals and their families for immigration settlement. But even from an attraction perspective, New Brunswick's ability to fully implement and reach the targets established by the PNP is highly problematic. Whereas in 2002 New Brunswick brought 104 new immigrants through the PNP, that figure represents $52 \%$ of the total allowable number as set forth in the agreement. ${ }^{450}$ Furthermore, when retention rates of immigrants are factored in, anecdotal information suggests that the intake numbers are even more dismal.

Through the PNP, the Province sends New Brunswick based employees to international markets in which there is interest for immigration to Canada, at which time prospective skilled immigrants apply to emigrate to Canada to New Brunswick. While the idea of having in-market based New Brunswick representatives is discussed periodically, the costs involved in establishing foreign offices is routinely deemed as prohibitive. A key concern that BNB (and later the Population Growth Secretariat) has with respect to the execution of the PNP is that immigrants who are nominated by the Province to come to and settle in New Brunswick may decide to leave for larger urban centres elsewhere in Canada, more often time than not to metropolitan centres such as Montreal, Toronto and Vancouver (derisively referred to as "MTV" by many Maritimers.) ${ }^{451}$

450 By comparison, the Province of Manitoba was able to attract 1,527 immigrants to the province through their respective PNP agreement, representing $764 \%$ of the allowable quota. (CIC, 2002: 110)

451 The notion that Atlantic Canada's interests regularly compete against MTV for FDI, immigrants and other resources is demonstrated by former Nova Scotia Premier John Hamm's comments upon the launch of a provincial immigration discussion paper in 
Unfortunately for the Province's immigration strategy, the Constitution permits free and unfettered internal movement of residents of Canada within Canada, and prohibits provincial governments from attaching conditionality of residency to the province with extension of entry to Canada and subsequent rights to application for Canadian citizenship. In order to therefore prevent provincial nominees from heading to other provinces immediately after entering Canada through the New Brunswick door, the Province must exercise diligence in its nominee attraction efforts. That said, the agreement continued to make sense for New Brunswick, and is demonstrated by its decision to extend the program post-release of the International Strategy. As noted in BNB's annual report,

The Province of New Brunswick entered into a five year renewable agreement with the federal government for delivery of the Provincial Nominee Program (PNP) in 1999. The PNP permits the province to play a more active role in the immigrant recruitment and selection process, however, all final immigration decisions remain under federal jurisdiction. ${ }^{452}$

Fourth, in recognition of the importance of immigration to New Brunswick for a wide range of social, economic and cultural reasons, the International Strategy promotes the proactive pursuit of partnerships with the Government of Canada, which shares jurisdiction over immigration matters with the provinces, to increase New Brunswick's total population while at the same time promoting and maintaining the officially bilingual

August 2004- "With a comprehensive, focused strategy for immigration - and a matching commitment to seeing this effort through - we can demonstrate to potential immigrants the world over that Canada is more than just Toronto, Montreal or Vancouver." Saint John Telegraph Journal, "N.S.'s Immigration Strategy Ambitious," December 7, 2004, p. A4.

452 Business New Brunswick, Annual Report 2002-2003: 15-16. 
character of the province. This predilection to cooperative immigration attraction efforts with the federal government is expressed as the Province's objective to:

Pursue a new partnership model with the federal government on immigration. This new arrangement will include entering into a formal arrangement with the federal Department of Citizenship and Immigration to set out specific objectives and targets. The Province of New Brunswick will work with local and overseas federal immigration offices to build awareness of the Province of New Brunswick's immigration interests and objectives. $^{453}$

While negotiating such a "new arrangement" might have offered some credence to New Brunswick's International Strategy as well as forward momentum in its goal of "province building," what would this new arrangement have looked like? Consider the following: At the time of the release of the International Strategy, provincial participation in federal immigration attraction efforts failed to yield significant return on investment. Although from 1986 to 2000 the Province of New Brunswick paid 2.87\% of Canada's total effort to attract landed business immigrants through the Immigrant Investor Program, the province received $0.44 \%$ of Canada's total business immigrant draw. As demonstrated, even the Province's pursuit of the PNP met with little success; what would another "new arrangement" hope to accomplish, especially when the International Strategy would provide no new funding for whatever new human and financial obligations that new approach would entail?

453 Province of New Brunswick, International Strategy, 2003: 15. 
Fifth, from the perspective of contending visions on what should comprise each order of government's respective immigration policy, one of the most serious issue in federalprovincial relations on immigration policy, however, relates to the disjuncture between:

a) The province's general objective of wanting to increase the population through retention of foreign students, nominations through the PNP, and attracting economic migrants in areas of significance and relevance to local needs; and

b) The federal government's desire to manage Canada's annual intake of immigrants through retention of authority over who is allowed to remain in Canada and who is not. $^{454}$

Finally, since the introduction of the International Strategy several organizational efforts at collaboration have been attempted, such as the establishment of a provincial F/P/T working group on immigration issues; shared cost partnerships on Language Instruction for Newcomers (LINC) program and promotion of francophone immigration to rural parts of New Brunswick. ${ }^{455}$ Despite such efforts, the objective of increasing New

454 The federal power of disallowance via its jurisdiction over issuance of entry visas is covered in greater detail later in this Chapter.

455 "The Government of Canada is investing $\$ 996,100$ to research a unique approach to attracting and integrating francophone immigrants into rural communities. This approach was developed by Carrefour d'immigration rurale Inc. in Saint-Léonard, which will lead the initiative [...] 'I am very pleased to say that together we have successfully developed an innovative approach to immigration in rural communities and more particularly in francophone communities,' [IGA] Minister Percy Mockler said. 'The Province has worked very closely on this initiative since June 2004, and we plan to continue the partnership in order to ensure the success of the Carrefour d'immigration rurale. I am very proud that this concept is being developed in Madawaska for New Brunswick and for all of Canada, a model to build upon in order to tackle the challenges of immigration and prosperity in rural communities'." IGA, News Release, "Innovative Approach to Rural Community Development," April 26, 2005. 
Brunswick's overall population has proven elusive, and no substantive spikes in population have been experienced.

Inter-Jurisdictional Breakdown: The Modern School in India Debacle

While this dissertation has employed the case example of India to demonstrate that in the area of trade and investment promotion there has been good federal-provincial collaboration, the same geographic market can be employed to demonstrate that in the area of immigration, the relationship has been less productive. In fact, it has been downright dysfunctional.

Pursuant to the Province's goal of internationalizing New Brunswick's education curriculum, the Department of Education signed a five year agreement to offer its high school programs online at the Modern School in Nagpur, India (MSI) on February 7 , 2006. As part of this arrangement, provincial high school curriculum would be taught to Grade 11 and 12 students by Indian teachers using the province's curriculum over four semesters, with the final semester to be delivered to the student in New Brunswick. ${ }^{456}$ The MSI program was initiated and in April 2007 eight students enrolled in the program applied to $\mathrm{CIC}$ for student visas to complete the fourth and final semester in New Brunswick.

456 Department of Education, Province of New Brunswick, News Release, "New Brunswick High School Courses to be Taught to Students in India," February 7, 2006. 
Of the eight visa applications for permission to enter Canada for study purposes, seven were rejected by CIC, with all seven rejected a second time on resubmission of the required documentation While the Province assisted in the preparation of these documents, ensuring that program acceptance, guardianship and other letters and requined documentation was in order, the challenge remained that CIC was not convinced that the students would return to India after the1 term of study As such, the policy disjuncture between the Province's desire to attract foreign students and increase immigration numbers and the federal government's restrictive "gatekeeper" function in light of 1ts POGG onented obligation to control Canada's immigration gateway was becoming increasingly clear

The issue, however, takes another turn

On Tuesday, June 19, 2007 Canada's High Commissioner to India David Malone was invited to address the members of the Focus India Plenary Working Group at DFAIT This committee, comprised of representatives from the federal and provincial governments, private sector and various segments of civil society (1ncluding educational institutions, Canada-India commercial promoters..), had as its mandate the goal of meeting twice per year to stimulate broad-based dialogue on Canada's efforts to engage India as part of the GCS and BRIC approach

During his presentation which initiated the session (after which he left, missing the F/P/T Q\&A period), Malone provided a pointed (yet collegial) admonishment to his federal 
colleagues and the provincial governments that Canada's promotion of educational opportunities and partnerships in India was far inferior to the marketing efforts of other jurisdictions such as the United Kingdom and Australia. ${ }^{457}$ Later on the day of the Focus India Plenary, New Brunswick along with several other provinces challenged Malone's suggestions, not along the lines that provinces had jurisdiction over education, but rather on the draconian manner by which CIC appeared to be exercising its mandate. Despite that New Brunswick requested that officials from CIC appear at the next planned session of the Focus India Plenary, nothing materialized from the interactıon, and the Focus India Plenary ceased holding its biannual meetings.

By way of concluding this section of Chapter 4 and moving onto consideration of New Brunswick's relationship with La Francophonie, it should be said that while trade and investment relations are characterized by complex intergovernmental relations in pursuit of fundamentally comparable goals, immigration is better described as being affected by overlapping junsdictions, conflicting prionties and seemingly mutually exclusive goals. The following pages will now move onto consideration of the third policy area, La Francophonie.

457 Proceedings of the Focus India Plenary, Robertson Room, DFAIT Headquarters, Ottawa, June 19, 2007. 


\section{La Francophonie}

New Brunswick's unique combination of French and English ethnic groups complicates any discussion of its political culture. ${ }^{458}$

Throughout this dissertation, mention has been made to New Brunswick's unique status as Canada's only officially bilingual province, and to the fact that this has afforded it various strategic opportunities to leverage federal assistance that allow it to "punch above its weight" in international matters. ${ }^{459}$ As such, the mechanisms and modalities through which the Province of New Brunswick pursues its international interests have particular significance vis-à-vis its membership to the multilateral organization collectively known today as La Francophonie, and require dedicated discussion in this third section of Chapter 4. Unlike other policy areas in which New Brunswick and other regional governments in Canada have interests such as promotion of trade and investment objectives, immigration and international development, New Brunswick's position in $L a$ Francophonie introduces a F/P/T dynamic that is anomalous to the other regional governments, and has definite implications with respect to the intergovernmental relationship.

This said, it is curious that New Brunswick's efficacious use of its role in La Francophonie and leveraging of the federal government's concern with the Québec government's pursuit of the Gérin-Lajoie principle discussed earlier has received little

$458 \quad$ Rand Dyck, Provincial Politics in Canada: Towards the Turn of the Century, $3^{\text {rd }}$ edition, Prentice Hall Canada Inc., Scarborough, 1996: 176.

459 Interview with Bernard Lord, Fredericton, June 8, 2007. 
attention from academic observers. As one of the very few academic commentators on New Brunswick's membership to La Francophonie, Benoit Bourque notes that although the Province participates as part of the Canadian delegation alongside the Province of Québec, and had (at time of writing) just hosted the $8^{\text {th }}$ Sommet de la Francophonie in Moncton in 1999, it was and has been the subject of very little academic research. ${ }^{460}$

This section examines New Brunswick's membership and pursuit of interests within the La Francophonie, how pursuit of specific action priorities contained in the International Strategy should be assessed, and some of the strategic intergovernmental considerations underpinning the alliance. In order to provide important context for understanding the strategic and power-oriented aspects of the Province's participation in the $L a$ Francophonie with the assistance of the federal government, as well as emphasize the deep weight that Québec's international activities have had on New Brunswick's own international policies and practices, the following pages provide some rather extensive historical and political context.

The term "La Francophonie" is used in broad parlance to identify the world aggregate of French-speaking persons in a non-state specific manner. It is by many accounts a difficult term and concept to grasp given its organizational imprecision- it is simultaneously and concurrently a social and linguistic umbrella, an intergovernmental organization with policy interests, and a vehicle of international development and summitry. ${ }^{461}$ Though the

460 Bourque, La Participation du Nouveau-Brunswick dans la naissance et le développment de la Francophonie, $2000: 1$.

$461 \quad$ See Jean-Philippe Thérien, "Canada and Francophone Multilateral Cooperation," in John English, Norman Hillmer, (eds.), Making a Difference? Canada's Foreign Policy 
term has been used to describe the worldwide diaspora of French-speaking peoples since the late $19^{\text {th }}$ century, its institutional application to the multilateral organization began in 1970 with the creation of the ACCT in Niamey, Niger. Creation of the ACCT resulted in its evolution to the Agence intergouvernementale de la Francophonie, which evolved into its present form, the Organisation internationale de la Francophonie (OIF).

The OIF is the international and intergovernmental institution through which orders of government meet in a collective fashion to discuss issues of shared significance. In 2007, the OIF was comprised of 55 member governmental jurisdictions with either a substantial French-speaking population or socio-cultural affinity with the French language. Its general mandate is to preserve, promote and advance the cause of French-speaking nations and participating orders of government. ${ }^{462}$ At the $5^{\text {th }}$ Francophonie Summit of the OIF held in Ouagadougou, Burkina Faso in 2004, the participating governments agreed to a ten-year strategic framework that conveyed the goal of exerting high level influence on the global Francophone population, with special emphasis in the following four areas where members demonstrate expertise and know-how:

- Promotion of the French language, culture and diversity;

- Promotion of peace, democracy and human rights;

- Support of education, training and higher education and research; and

in a Changing World Order, Toronto, Lester Publishing Limited, 1992: 54-5; and Greg Donaghy, Neal Carter, "There Are No Half-Countries: Canada, La Francophonie, and the Projection of Canadian Biculturalism," in James, Michaud, O'Reilly, (eds.), Handbook of Canadian Foreign Policy, 2006: 133-164.

462 Actions: Organisation Internationale de la Francophonie, URL: http://www.francophonie.org/actions/index.cfm, Accessed : November 2008. 
- Encouraging cooperation and solidarity in sustainable development. ${ }^{463}$

As an intergovernmental organization, the OIF offers membership to states that have a French-speaking population, or socio-cultural, historical connections to the worldwide Francophone diaspora. In recognition that federations sometimes include regional governments with particularly strong French language affinities, membership privileges to the OIF were extended, with a proviso. According to Article 10 of la Francophonie's Charter, ${ }^{464}$ in recognition of state sovereignty regional governments that sought the right to sit at the Francophonie table as participants were required to have the approval of their respective central governments. With respect to Canada, Québec was granted status of participant government in 1971, and New Brunswick was granted the same in 1977.

Since 1986 Francophonie member governments ${ }^{465}$ gather at a biannual summit where issues pertaining to the organization's mandate and work are discussed. As the result of its receipt of annual funding for the purpose of sitting at the Sommet table, New Brunswick is a regular participant to these summits, as well as the Conférence ministérielle which precedes the Summit for planning purposes. The only instances that

463

Ibid.

464 "Dans le plein respect de la souveraineté et de la compétence internationale des États membres, tout gouvernement peut être admis comme gouvernement participant aux institutions, aux activités et aux programmes de l'OIF, sous réserve de l'approbation de l'État membre dont relève le territoire sur lequel le gouvernement participant concerné exerce son autorité, et selon les modalités convenues entre ce gouvernement et celui de l'État membre." Article 10, Francophonie Charter adopted by the Ministerial Charte de la Francophonie adoptée par la Conférence ministérielle de la Francophonie, Antananarivo, le 23 novembre $2005: 7$.

465 While a multitude of non-governmental organizations are associated with the international Francophonie and are dedicated to promote worldwide preservation and proliferation of the French language and culture, this dissertation only considers the intergovernmental functions of the La Francophonie. 
New Brunswick does not routinely send a representative to delibeiations of the OIF or its associated appendages is when the issues for deliberation clearly fall outside the competencies of the Canadian provinces and are the preserve of the central government, such as those relating to $\mathrm{POGG}^{466}$

Under the umbrella of La Francophone are a number of institutions, the oldest of which is the Conference of Ministers of Education in French-Speaking Countries (CONFEMEN) Through CONFEMEN, the Minısters of Education of the member states and governments work together to coordinate and promote efforts atound education, technical and vocational trainıng, reduction of poverty and educational capacity-building. Given the constitutionally-based division of federal and provincial government policy jurisdiction in Canada, participation in the CONFEMEN is an area in which intergovernmental collaboration has been important. ${ }^{467}$

Another institution of La Francophonte that involves Ottawa and the provinces working 1n cooperation 1s the Conference of Youth and Sports Ministers of French-Speaking Countries (CONFEJES). Created in 1969, the goals of CONFEJES include: promotion of youth and sport involvement with members; encourage social and financial backing of 466 For example, the Province did not send representatives to sit in on meetings of the OIF's Conseil permanent de la Francophonie (CPF) which deliberated the organization's response to government instability and coup d'etat efforts in Mauntania 2008, Guinea 2008; and Madagascar 2009.

467 New Brunswick has typically favoured Minister-level participation at the CONFEMEN rather than the CONFEJES; as such the Minister of Education participated in the meeting of the CONFEMEN in Lomé, Togo in November 2007 as well as the 53rd session of the CONFEMEN in Caraquet, New Brunswick from June 1 to 8, 2008 During that session, Minister Kelly Lamrock was appointed President for a two-year term. Department of Education, 2007-2008 Annual Report, p 16. 
young entrepreneurs; foster greater community harmony; develop athletic and competitive skills; and encourage sporting events and other exchanges where young Francophones can share ideas and make contributions to a healthy world.

\section{Provincial Interests}

The following paragraphs discuss New Brunswick's interests in La Francophonie, and provide some background on the "big picture" political and organizational culture that influences its participation in this multilateral organization.

Globalization has resulted in provincial governments having to adopt more active roles in international matters while at the same time minding their relationship with Ottawa. In the case of New Brunswick, factors relating to its "smallness" make these calculations and machinations even more important, in that such regional governments must balance a proactive international agenda with sensitivity of the federal government's concern over any one province dominating Canada's writ-large projection of identity abroad. In the case of New Brunswick's interests in La Francophonie, however, the need to tread lightly has been less important than is the case with other policy issues (such as trade and investment promotion and immigration) given pressures already exerted by Québec's aggressive paradiplomatic and protodiplomatic modus operandi pursuant to the GérinLajoie doctrine. Interestingly, New Brunswick's interests in La Francophonie are one of the few policy areas involving paradiplomacy in which the federal government stands to benefit from greater inter-provincial penetration and activism. 
Before further discussing the political aspects of New Brunswick's participation in La Francophonie though, some social and historical context is required.

Given that approximately $1 / 3$ of New Brunswick's population is Francophone, and that as a result of the Province's linguistic and cultural duality there are long-standing misgivings over the poor treatment of Francophones in New Brunswick and the Maritimes region, the Province has tried to reflect linguistic duality in the extension of services to the general public, as well as entrenched rights for the public to access government services in the language of their choice. Under the Premiership of Louis Robichaud, legislation was enacted to give equal weight and applicability of the French language to the publication of government literature, provision and performance of government services and implementation of regulatory functions.

In 1981 the Province introduced An Act Recognizing the Equality of the Two Official Linguistic Communities in New Brunswick, which effectively recognized that Anglophones and Francophones in New Brunswick were entitled to equality of status, rights and privileges, and the right to institutions through which to pursue cultural, educational and social activities. In addition, an Official Languages Act was enacted to ensure that the work of government in providing services and enforcing regulations was done so in both official languages. ${ }^{468}$ Moreover, the Province has enacted wholesale amendments to its own internal bureaucratic structure and modus operandi with the introduction of Anglophone and Francophone Deputy Minister in charge of English and

468 For more information see Official Languages Act, Assented to: 1969 and 2002 and An Act Recognizing the Equality of the Two Official Linguistic Communities in New Brunswick, Assented to: July 17, 1981. 
French language services respectively, jointly reporting to a single Minister in charge of the portfolio in Ministries such as Health and Education.

It is also significant to note that New Brunswick's official bilingualism was, at the behest of the Province, enshrined in the Constitution Act, 1982 and Canadian Charter of Rights and Freedoms. The significance of these social and legal commitments would prove to play a significant calculus in the provincial government's orientation of New Brunswick's international activities, as well as strategic engagement with the federal government.

Nevertheless, it is precisely this strong emphasis on the French and francophone character of New Brunswick, as well as its commitment to official bilingualism, that underpins the seriousness with which it considers its membership to La Francophonie, and intergovernmental relationship with the OIF.

At the time of the International Strategy's development in 2002-2003, the Francophonie and International Relations Division of IGA was responsible for the administration of the federal-provincial Official Languages Program, coordination of francophone stakeholders with interests in international relations, and administration of federal funding for New Brunswick's participation in La Francophonie. Civil servants working on any issue attached to the Francophonie were members of the Francophonie and Official Languages Branch (FOLB), which coordinated and promoted within the province (i.e. in the work of the Province's ISWG and with civil society organizations), 
Canada (i.e. in collaborating with other provinces and the federal government), and throughout the world.

In the corporate policies that have been discussed in this dissertation, there are numerous references to the Province's interests as they relate to La Francophonie, but little actual detail on how those interests are to be achieved. For example, the only reference to La Francophonie made in the 2002 Prosperity Plan is made on page 40 of the 41 page document, and simply calls for an "enhanced level of activity in La Francophonie." 469 The International Strategy provides greater detail on the objectives sought, but provides little by way of a pathway to attain those objectives other than advancing general support,

New Brunswick's special status in La Francophonie offers a strategic gateway to the member countries. A new corporate action plan is currently being developed to fully engage all provincial departments and our international partners in pursuing our trade, investment, immigration and cultural interests in the most effective and efficient manner. In its relations with l'Organisation internationale de la Francophonie, the Province of New Brunswick will participate in discussions on priority issues for the province and promote its interests. The Province of New Brunswick will also pursue our specific immigration, investment and trade interests with the most promising member states, with special emphasis on France. ${ }^{470}$

Similar principles are advanced in the context of internal work planning; IGA's commitment to advancing itself as a bilingual jurisdiction was reflected in its Intergovernmental Affairs Corporate Strategy, which notes the goal to promote "the 
cultural diversity and vitality of New Brunswick's two official linguistic communities on the provincial, national and international stage.,"471

New Brunswick became a "participating government" in the OIF in 1977 (the reasons for which are articulated later in this section). Since then, the Province has sought to remain an active member of the intergovernmental organization through its bilateral agreement with the federal government. As noted by former Minister of IGA and Minister responsible for the Francophonie,

New Brunswick's participation as a government member of the International Organization of the Francophonie is a chance for us to show our commitment to developing partnerships to help build a better world [...] International Francophonie Day is an opportunity for the people of New Brunswick to celebrate this link that unites about 170 million French speakers around the world. ${ }^{472}$

New Brunswick's desire to pursue its International Strategy and relations with the federal government as they relate to the Francophonie is openly professed, and spans multiple

471 Intergovernmental Affairs Corporate Strategy, URL: http://www.gnb.ca/0056/Publications/strategy-e.asp, Accessed: November 2008. This strategy also notes that IGA's core business areas include: "Promoting the benefits and vitality of New Brunswick's two official linguistic communities; and Maximizing the economic and cultural benefits to New Brunswick as a member government of L'Organisation internationale de la Francophonie," and that strategic priorities include enhancing, "the current level of public involvement in New Brunswick's preparation for and participation in La Francophonie, including the bi-annual Francophone Summit." Although the access date for this citation does not match up with the 2002-2003 timeframe, the IGA mandate and core services descriptions had not changed for several years.

472 Province of New Brunswick, IGA, Press Release, "International Francophonie Day, March 20 (04/03/19)," March 19, 2004. 
sectors. The following table provide a detailed look at the sum-total of New Brunswick's tie-ups with La Francophonie:

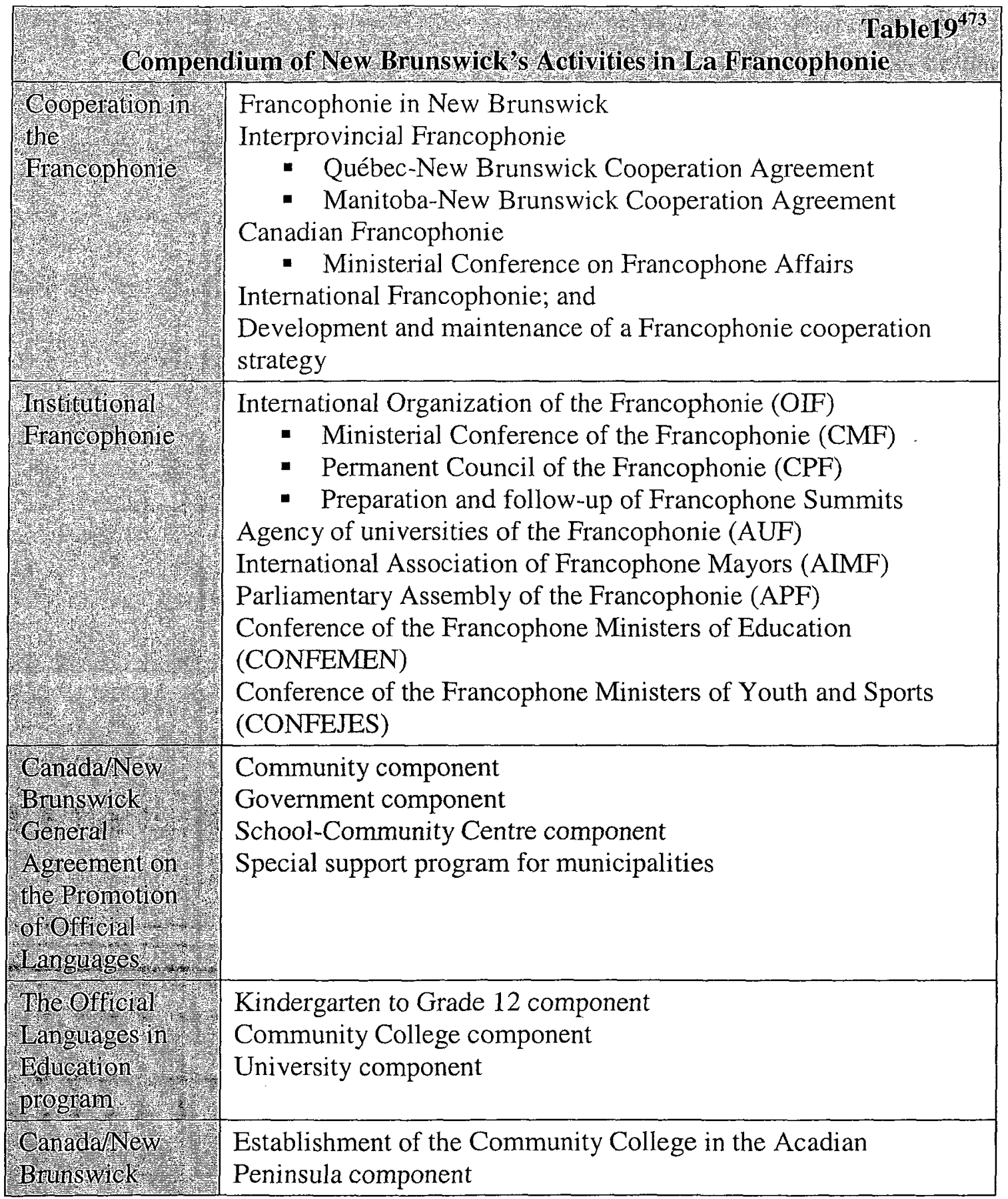

473 Province of New Brunswick, IGA, "Francophonie/ Official Languages," URL: http://www.gnb.ca/0056/Francophonie/index-e.asp, Accessed: January 12, 2009. 


\begin{tabular}{|l|l|}
\hline Special & Development of the Université de Moncton component \\
Agreement & \\
related to Post- & \\
secondary & \\
education & \\
\hline
\end{tabular}

In the Guiding Principles of the International Strategy it is noted that, "We are an active member of the La Francophonie and will buld on our success in this important forum." ${ }^{474}$ Near the conclusion of the International Strategy, the Province provides a more multi-sectoral, expansive insight into the role it believes its special relatıonship and connection with La Francophonie can play,

\begin{abstract}
New Brunswick's special status in La Francophonie offers a strategic gateway to the member countries. A new corporate action plan is currently being developed to fully engage all provincial departments and our international partners in pursuing our trade, investment, immigration and cultural interests in the most effective and efficient manner. In its relations with l'Organisation internationale de la Francophonie, the Province of New Brunswick will participate in discussions on priority issues for the province and promote its interests. The Province of New Brunswick will also pursue our specific immigration, investment and trade interests with the most promising member states, with special emphasis on France. ${ }^{475}$
\end{abstract}

Despite this close relationship envisaged with France, New Brunswick is unwilling to pursue greater representation and empowerment of its Francophone population and the cause of effective articulation of French-language interests by any political or intergovernmental means necessary, such as unilateral or proto-diplomatic activity that may conflict with the interests of the federal government. It is these same lines that

$\begin{array}{ll}474 & \text { Province of New Brunsw1ck, International Strategy, 2003: } 7 . \\ 475 & \text { Province of New Brunsw1ck, International Strategy, 2003: } 23 .\end{array}$ 
Québec has dared to cross in support of its commitment to foreign policy independence, and which has had the effect of directly strengthening New Brunswick's relationship with the federal government.

For example, in 1967 French President Charles de Gaulle paid a state visit to Canada during which time there were powerful and growing "province-building" and "Québecbuilding" forces at play, which were of concern to the federal government. Despite Prime Minister Pearson's fears that de Gaulle may further fan the flames of Québec separation, he was extended the courtesy to address a large crowd of well-wishers from the balcony of Montreal City Hall by then Mayor Jean Drapeau on July 24. During the speech, de Gaulle declared "Vive le Montréal, vive le Québec, vive le Québec libre, vive le Canada français, vive la France!"476 to thousands of cheering Québecois. Upon learning of this challenge to Canada's sovereignty and nationalistic stability then New Brunswick Premier Louis Robichaud, architect of New Brunswick's official bilingualism policies, wrote to Prime Minister Pearson to register his disagreement with de Gaulle's statement supporting the view that an independent Québec was desirable, as well as canceling his invitation to a state dinner in the General's honour. ${ }^{477}$ In doing so, Robichaud was able to demonstrate a clear contrast between Quebec and New Brunswick, presumably to the province's benefit in its relationship with the federal government.

476 See Arthur E. Blanchette, "Vive le Québec Libre," Discours de Charles de Gaulle, July 24, 1967, Montréal City Hall, Canadian Foreign Policy, 1945-2000 : Major Documents and Speeches, Durndurn Press Ltd., 2000: 229-230.

477 Bourque, La Participation du Nouveau-Brunswick dans la naissance et le développment de la Francophonie, $2000: 8$. 


\section{Federal Interests}

The Government of Canada's interests with respect to La Francophonie can be categorized into:

a) Its organizational-related interests relating to advancing the Canada's writ large interests within the Francophonie; and

b) Its strategic, intergovernmental-related interests that include positioning the federal government in relation to the positioning efforts of the provinces, namely Québec.

By way of structure, the remainder of this section will discuss the federal government's organizational goals, and the final part of this discussion of La Francophonie as a policy area will look at the federal government's pursuit of strategic goals as a function of policy intersection and a mechanism of strategic collaboration.

\section{Organizational Goals}

Membership in La Francophonie is one of the main thrusts of Canada's foreign policy. From a domestic perspective, Canada's involvement in la Francophonie highlights the country's linguistic duality and supports and promotes Canada's French community. Internationally, la Francophonie is a natural sphere of influence for Canada, similar to the Organization of American States [OAS] and the Commonwealth. It is also a multilateral forum for cooperation and dialogue in which Canada can use its influence to promote the values its citizens wish to share. ${ }^{478}$

478 DFAIT, “Canada's Goals in La Francophonie," URL:
http://www.international.gc.ca/franco/index.aspx, Accessed: November 12, 2008. 
Given the importance of the French language to Canada's past and present, and the notion of les deux peuples fondateurs, the Government of Canada has taken a keen interest in the creation and advancement of La Francophonie. The importance of the demographic factor is illustrated by taking a cursory view of recent Canadian figures related to self-identification of language skills. Data from the 2006 Canadian population census (see table below) demonstrates that Canada as a nation is comprised of a significant population of native French speakers as well as bilingual (English-French) and multilingual (plus French) speaking Canadians.

From a provincial distribution perspective, there is evidence that the majority of French speakers in Canada is concentrated between Ontario (4\% French as mother tongue), Québec (80\%) and New Brunswick (33\%). The overall Canadian national average of native French speakers stood at $22 \%$.

\begin{tabular}{|c|c|c|c|c|}
\hline Population by mother tong & 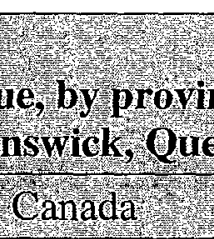 & ceand te & 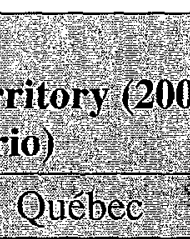 & 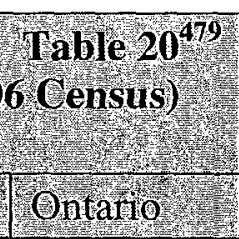 \\
\hline otalipopilation & $31,241,030$ & 719,650 & $7,435,905$ & $12,028,895$ \\
\hline gle respons & $30,848,270$ & 714,490 & $7,339,495$ & $11,853,565$ \\
\hline nglish & $17,882,775$ & 463,190 & 575,555 & $8,230,705$ \\
\hline & $58 \%$ & $64.8 \%$ & $7.8 \%$ & $69.4 \%$ \\
\hline & $6,817,655$ & 232,975 & $5,877,660$ & 488,815 \\
\hline$p h$ & $22.1 \%$ & $32.6 \%$ & $80 \%$ & $4.1 \%$ \\
\hline & $6,147,840$ & 18,320 & 886,280 & $3,134,045$ \\
\hline 县 & 392,760 & 5,160 & 96,405 & 175,330 \\
\hline
\end{tabular}

479 Source: Statistics Canada, 2006 Census of Population, http://www40.statcan.gc.ca/101/cst01/demo11b-eng.htm. Accessed: May, 2008. 


\begin{tabular}{|c|c|c|c|c|}
\hline English and French & 98,625 & 4,450 & 43,335 & 32,690 \\
\hline $\begin{array}{l}\text { English and non-official : } \\
\text { language }\end{array}$ & 240,005 & 560 & 16,200 & 131,290 \\
\hline $\begin{array}{l}\text { French and non official } \\
\text { language }\end{array}$ & 43,335 & 120 & 31,350 & 7,790 \\
\hline $\begin{array}{l}\text { English, Frênchand non-n- } \\
\text { official language }\end{array}$ & 10,790 & 30 & 5,520 & 3,565 \\
\hline
\end{tabular}

Canada's participation in La Francophonie is expressed on a political level and a cooperation-onented level On the political level, high level and diplomatic representation by the federal government is managed by the Francophonie Affarrs Division of DFAIT From an organizational perspective, this group provides corporate federal leadership on issues such as intra- and inter-departmental mobilization and coordination, financial and budgeting considerations, political and economic interactions with the organization; planning of events such as Summits and Ministerial conferences, and liaison with the provincial governments Similar to the central agency function played by IGA, the Francophonie Affarrs Division coordinates its activities with the federal departments and agencies of CIDA, Industry Canada, Justıce, Environment, Canadıan Heritage and the Privy Councıl and PMO

The federal government's financial contributions to underwrite operational costs associated with the operation of the OIF are largely managed through CIDA, given that the majority of its members are developing African nations with considerable financial, organizational and human resource-oriented shortcomings. Through its Francophone Program, during the 2007-2008 fiscal year CIDA made over $\$ 9$ million of contributions to the various international cooperation programs of the OIF and its associated 
appendages. ${ }^{480}$ In some cases, certain jurisdictions that receive multilateral funding assistance through the OIF are also eligible to receive bilateral financial assistance through CIDA through the Canadian Overseas Development Assistance (ODA) program, as well as integrated non-financial assistance through other federal departments and agencies such as Industry Canada, Heritage Canada, the International Development Research Centre, Environment Canada and Justice Canada.

In terms of benefits, Canada's participation in La Francophonie affords a wide range of benefits, the most important of which is enabling it to strengthen its image as a Frenchspeaking country, allowing it to adapt to the changing international environment, and have greater influence in diplomacy and international relations (specifically in NorthSouth relations). ${ }^{481}$ Other benefits realized by the federal government's membership to La Francophonie include:

a) Allowing multilateral expression of Canada's foreign policy and avoidance of cultural assimilation with the United States;

b) Counterweight to Canada's membership to the Commonwealth;

c) Forum in which to pursue human rights, international development and environmental protection objectives;

d) Prospect new commercial markets (not as significant); and

480 Canadian International Development Agency (CIDA), "CIDA and La Francophonie," URL: http://www.acdi-cida.gc.ca/CIDAWEB/acdicida.nsf/En/JUD1211134328-PY8, Accessed: January 11, 2009.

481 Thérien in English and Hillmer, 1992: 61. 
e) Demonstrate to Québec a commitment to Francophone issues thereby exerting a positive influence in favour of national unity.

Policy Intersections and Collaborative Mechanisms

A Brief Historical Recap

From a historical perspective, earlier chapters in this dissertation have discussed how the evolution of Canada's system of federalism has inherently favoured a high degree of centralization and "ownership" of foreign affairs by Ottawa. Specifically, it was noted that Prime Minister Macdonald deeply held the view that regional governments should not be active on the world stage despite the international aspects of areas within their own constitutionally-determined spectrum of power. Given Wheare's notion of airtight compartments of intergovernmental jurisdiction and Livingstone's belief that civil society should have an enhanced role in the administration of the federal state, foreign affairs policy in Canada provides a strong counterfoil to this unitary conception of the state's jurisdiction over international policy. Such views, however, failed to gain political currency during formative years of La Francophonie though- note Prime Minister Pierre Trudeau's comment that Canadian foreign policy cannot be fragmented given that although there are big states and small states, there are no half states. ${ }^{482}$

482 Pierre Elliott Trudeau cited in Bourque, 2000: p. 13 citing Michel Tétu, Qu'est-ce que la Francophonie, $1997: 241-2$. "La politique étrangère du Canada ne peut être fragmentée. Il existe de grands et de petits pays : il n'existe pas de demi-pays." 
In light of these sensitivities, it should come as no surprise that with the dawning of Québec nationalism during the Quiet Revolution and calls for greater self-expression on the international stage came resistance from Ottawa. Even though Québec may have been within its rights to press for greater autonomy in international matters, fear of irrelevancy, loss of the influence and the need to discourage other provincial recalcitrance played heavily in Ottawa's domestic management of its foreign policy calculus. In order to give some context to its use of New Brunswick as a counterbalance to the independent foreign policy of the Province of Québec, the following paragraphs take a closer look at the process by which Québec agitated to become a member of the Francophonie.

\section{Québec, Ottawa and the Road to the ACCT}

In light of the federal government's historic belief ${ }^{483}$ that it alone should represent Canada's interests through the articulation of foreign agreements and treaties, Québec's assertion that it had the right to join the organization as a participating government (on the grounds that policy issues to be explored by the ACCT related to areas within the

483 See reference to a statement issued by Secretary of State for External Affairs (SSEA) Paul Martin in Ottawa, April 23, 1965 with respect to the Provinces and their Treaty-Making Powers cited in Arthur E. Blanchette, Canadian Foreign Policy, 19452000: Major Documents and Speeches, Durndurn Press Ltd., 2000: 229. "[...] once it is determined that what a province wishes to achieve through agreements in the field of education or in other fields of provincial jurisdiction falls within the framework of Canadian foreign policy, the provinces can discuss detailed arrangements with the competent authorities of the country concerned. When a formal international agreement is to be concluded, however, the federal powers related to the signature of treaties and the conduct of over all foreign policy must necessarily come into operation." Vengroff and Rich (2006: 110), however, do point out that in Canada, "[...] lack of constitutional clarity makes paradiplomacy possible, though their respective national governments typically frown upon it and try to circumscribe it as best they can." 
provincial jurisdiction) was met with consternation in Ottawa. This tension would eventually drive New Brunswick's strategic entry to the OIF.

As a state level member of the OIF, the Government of Canada is granted the power to allow or disallow provinces from joining the organization through Article 10 of the Francophonie Charter. While the federal government notes that in keeping with the spirit of openness it allows Québec and New Brunswick to join as participating governments, close examination of the wording of its rationale for doing so (noted below) reveals a subtle wording choice that conveys the idea that the provinces were "invited" by the federal government to join the organization, and that the provinces had to "negotiate" those invitations with Ottawa alone.

Under agreements negotiated with the federal government in 1985 , these two provinces are full participants in matters of co-operation. Also, after consulting with and obtaining the approval of the Prime Minister of Canada, Québec and New Brunswick can act on global economic issues of interest to them. The agreements also give them status as "interested observers" when international political issues are discussed during the summits. For a number of years, the Government of Canada has invited the governments to take part in the summits by appointing a representative to the Canadian delegation. ${ }^{484}$

Québec's 1971 accession into OIF came at a time when Québec nationalism and the sovereignty effort was very strong, and when the province had already challenged the unity of the Canadian state by participating in other international multilateral activities normally reserved for the Government of Canada. New Brunswick's entry into the ACCT 484 DFAIT website, "Canada in La Francophonie," URL: http://www.international.gc.ca/franco/index.aspx?menu_id=1\&menu=R, Accessed: January 30, 2009. 
in 1977 as a participant government was a consequence and by-product of these political and strategic manoeuvrings between Ottawa and Québec City. In order for New Brunswick to play this mediating role for the federal government, however, it was necessary for Ottawa to take into consideration the financial imperative of the Province's participation in this multilateral organization. There were little questions for Ottawa that New Brunswick would embrace a spirit of cooperation and collaborative, and would counter-balance Québec's independent presence in La Francophonie.

To quantify this tension, in January 1968 the Government of Québec was directly invited to send representatives to attend a CONFEMEN meeting in Libreville, Gabon. As suggested by Canada's External Affairs Minister Paul Martin Senior, it was the federal position that the Government of Canada should lead the delegation, under whose aegis the provinces could pursue representation and participation. Due to diplomatic and political tensions between France and Canada (presumably as the result of de Gaulle's incendiary Vive le Québec libre speech in Montreal the year previously) Québec, and not Canada, was extended the official invitation for participation in the conference.

This move caused considerable diplomatic waves, causing Canada's freshly-appointed Ambassador to Gabon, J.E. Thibault, to take up the matter with the Gabonese Foreign Minister. Despite the obvious negative consequences of this move, Gabon aimed to quell tensions; DFAIT historian John Hilliker recounts,

Eventually, Gabon notified Ottawa that, as had long been the view in Libreville, Paris, and Quebec City, the province's minister of education, 
Jean-Guy Cardinal, was being invited to the meeting on a personal basis. This modest status was not apparent when the conference took place from February 5 to 10, 1968, for Québec's delegation was accorded national state treatment. On his return, Cardinal claimed 'an important precedent that showed Québec's desire to participate' in la Francophonie. ${ }^{485}$

The response from Ottawa was one of outrage.

SSEA Martin was outfoxed by the Québec delegation, and even his attempts to position Thibault as Canada's chargé d'affaires in Gabon and secure a meeting with Gabon's President Omar Bongo (Thibault was rebuffed as he had not yet presented his ambassadorial credentials to the government) had failed. ${ }^{486}$ Immediately after the conference at which the Québec government had purported to conduct itself with air of sovereignty, Canada suspended diplomatic relations with Gabon. Just as relations between Gabon and Canada smoothed over, the federal government did not receive an invitation to attend another reunion of French Education Ministers in Paris in April 1968, which in turn reignited the ire of Ottawa given that according the Government of Québec with diplomatic status gave it yet one more legitimate claim to its push for unfettered autonomy, and eventually, independence. Although Canadian academics such as the well-respected Louis Sabourin called for restraint from both sides and a commitment to

485 John Hilliker, Donald Barry, Canada's Department of External Affairs, Volume II, Coming of Age, 1946-1968, Montreal, McGill-Queen's University Press, 1995: 401-2, quoting from J.L. Granatstein, "External Affairs and National Defence," in John Saywell, (ed.), Canadian Annual Review, 1968 (Toronto: University of Toronto Press, 1969), p. 223.

486 See Robin Stewart Gendron, Raoul Dandurand, Towards a Francophone Community: Canada's Relations with France and French Africa, 1945-1968, Montreal, McGill-Queen's Press, 2006: 131-134 for a well-rounded discussion. 
"mutual trust," $" 487$ Ottawa was in no mood to place what it saw as the future of a unified Canada in the hands of the Québec government.

This time, prior to the Paris follow-up meeting, Ottawa had conveyed its desire to see a Canadian delegation attend the conference with Québec's Minister of Education as mission head accompanied by officials from New Brunswick and Ontario, both of which as demonstrated in the above table have significant francophone populations. While Ontario did not accept the invitation for fear of damaging Ontario-Québec relations, New Brunswick accepted the invitation in order to advance its own educational interests as well as position itself between the Ottawa and Québec City.

J.F. Bosher observes that after the Gabon conference, the federal government attempted to position several provinces in addition to New Brunswick to join La Francophonie as a way to deemphasize the weighty position being cultivated by Québec, ${ }^{488}$ a tactic that was recognized by Québec's Deputy Minister of Intergovernmental Affairs Claude Morin as a tactic to subsume the Province's participation in international conferences as but one of many Canadian provinces with interests of their own. Nevertheless, New Brunswick did

487 "If Québec demands too much in the field of international affairs, this cannot but lead to the establishment of a dual image of the country on the world scene which is an inevitable step towards breaking up Canada. On the other hand, if English-speaking Canadians do not recognize that Québec has every right to develop international activities which will favour the self-fulfilment of French Canadian society, this will give ample proof that they do not wish to accept French Canadians as equal partners in Canada." Louis Sabourin, "Special International Status for Québec?," in Stephen Clarkson, (ed.), An Independent Foreign Policy for Canada?, Toronto, The Canadian Publishers, 1968: $108-9$.

488 J.F. Bosher, The Gaullist Attack on Canada, 1967-1997, Montreal, McGillQueen's Press, 2000: 57. 
ultimately leverage the federal government's fear that an internationally autonomous Québec would fan international sympathies for its campaign for separatism, and used the opportunity to broker some significant benefits. ${ }^{489}$

Furthermore, Bosher notes that as Canada's Under-Secretary of State for External Affairs, Marcel Cadieux took particular efforts to position Canadian diplomats strategically so as strengthen relations across La Francophonie and combat perception that Québec's voice was in fact the de facto voice for Canada in the French-speaking world. As part of this bolstering of the Canadian brand within La Francophonie, proxies for the federal government such as New Brunswick were tasked with aggressively stepping up their participation in some of the developmental functions associated with the organization.

By cultivating strong cultural relations with the French-speaking countries Canada might hope to engage Quebec together with other provinces, particular New Brunswick, Ontario, and Manitoba, in Canadian policy abroad and thereby weaken bilateral links between Quebec and Paris. It was to this end that Ottawa began to offer more aid and stronger diplomatic links with French-speaking countries in Africa. ${ }^{490}$

By the time that the next major meeting relating to La Francophonie was to take place in Niamey, Niger where the foundations of what would become the ACCT were to be laid

489 Bourque, 2000: 15. Speaking about New Brunswick's acceptance of the federal invitation to participate in La Francophonie as a participant government, Bourque notes, "Encore une fois, le Nouveau-Brunswick entre en scène à côté du Canada pour contrebalancer le poids du Québec."

490 Bosher, 2000: 98-99. He further observes, "Stirred by Quebec's involvement in la Francophonie, Ottawa endeavoured to recover the leadership of Canadian participation by bringing in representation from New Brunswick, Ontario, and Manitoba." 117. 
in February 1969, the Pearson administration in Ottawa, Johnson administration in Québec City and de Gaulle administration in Paris had changed, resulting in a softening of tense trilateral relations and pitched tone of negotiations surrounding participation in international multilateral summitry.

Prior to the Niamey Conference, however, External Affairs came to learn that the President of Niger Hamami Diori, as chair of the conference, planned on extending the Canadian invitation to the Government of Québec, a decision that was made with the counsel of France's Minister of Education, and that Diori was under the (mistaken) impression that Québec spoke for the French population of Canada. To counter the possibility of another debacle reminiscent of Gabon, Canada's new incoming Ambassador to Niger Thomas Malone met with Diori on the occasion of his presentation of diplomatic credentials to advise the President that Ottawa considered it a breach of protocol for Québec to receive the Canadian invitation of participation. "Malone went on to explain that French Canadians did not just live in Quebec- he pointed to New Brunswick as an example- and this fact surprised Diori so much that he asked the ministers and other dignitaries if they had been aware of it." ${ }^{491}$ And so was yet another example of how New Brunswick's bilingualism and biculturalism has been leveraged by the federal government as a tool with which to temper Québec's internationalism.

After the fact, to avoid the risk of unfettered political support for Québec autonomy reminiscent of the Gabon and Paris meetings, Prime Minister Trudeau met with Niger President Diori Hamani in September 1969 to discuss the terms of Canada's participation 491 See Gendron and Dandurand, 2006: 130. 
in the new ACCT, as well as convey subtle signals that the Canadian government would be in the position to bankroll the fledging organization provided that the federal government's prerogative to participate was respected. He noted that

Canada has promised its full support in this project; we have already made a financial contribution to the agency's provisional secretariat. We shall maintain our support [...] The Canadian Government intends to support African efforts towards economic expansion and social development. ${ }^{492}$

As another result of these changes in political representation, there was a marked diminution of the diplomatic gamesmanship that was being played between Québec, Ottawa and Paris. The Government of Canada consented to support Québec's membership to the OIF effective in 1971, with New Brunswick's participation finalized in 1977. At time of writing this inclusion retains the same significance; New Brunswick's membership to the OIF is the only multilateral international intergovernmental organization in which the Government of New Brunswick has direct participation. As noted by Mirelle Cyr, Premier's Sherpa to the Francophonie, the strategic value of the deal was immediately recognized,

Québec wanted to be a member of the ACCT, and the federal government thought that only their participation as a Canadian province would not result in a good power equilibrium between Québec's position and Canada's interests. It was on this basis that the federal government invited New Brunswick to join the Francophonie as a participating government, and that we saw strategic value in pursuing this partnership with Ottawa. ${ }^{493}$

$492 \quad$ Statement by PM Pierre Trudeau, On the Occasion of the Signing of Agreements with the President of Niger, Mr. Diori Hamani, Ottawa, September 19, 1969, in Blanchette, 2000: 237.

493 Interview, Mirelle Cyr, Assistant Deputy Minister, FOLB, January 14, 2009. 
At time of writing, New Brunswick is the beneficiary of an agreement with the federal government to provide approximately $\$ 1$ million every two years for the financing of New Brunswick's activities within the OIF, including participation in meetings of the Conférence Ministérielle, Sommet de la Francophonie, CONFEMEN, CONFEJES and ad hoc meetings as required. ${ }^{494}$ This funding vehicle has been in existence since New Brunswick first decided to join the ACCT, and has remained remarkably resilient to recessions, program spending reviews and the peering eyes of central agencies. This degree of cooperation and collaboration stands in stark contrast to New Brunswick's pursuit of interests in other areas like trade, investment and immigration promotion, where it struggles for comparable levels of intergovernmental cooperation, funding and/or support. This federal funding for francophonie-related activities is crucial, without which New Brunswick would likely not be able to participate in the OIF to the extent that it does. Bourque points out,

Le gouvernement du Canada a fourni et fournit l'ensemble des fonds nécessaires pour financer les actions gouvernementales néo-

494 For the latest information on this federal-provincial agreement, see Government of Canada, News Release, "Signing of An Ottawa-Fredericton Memorandum of Understanding on New Brunswick's Participation in International Francophonie," March 18, 2009. "With its Acadian and francophone communities, New Brunswick has made a concrete contribution to strengthening the influence of the international francophone community since joining the international Francophonie in 1977. New Brunswick's participation in the international Francophonie is consistent with the province's economic and social development goals. Canada is proud of its linguistic duality and participates actively in the promotion and dissemination of the French fact throughout its territory and on the international scene through concrete action, like the Ottawa-Fredericton memorandum of understanding, which will help it meet its Francophonie commitments. New Brunswick played a major role in the recent Francophonie Summit in the city of Québec, not only as a participant, but also in planning and executing the event. The strong collaboration between the governments of Canada and New Brunswick allows important International Organization of $\mathrm{La}$ Francophonie (OIF) issues to progress significantly. 
brunswickoises dans le domaine. Sans cet argent, le Nouveau-Brunswick ne participerait pas aux activités de la Francophonie. ${ }^{495}$

In addition to participation in the institutional mechanisms of the OIF, New Brunswick leverages its membership and position in La Francophonie to pursue other interests that dovetail with its International Strategy. The following paragraphs provide a brief look at some of those areas.

International Development

The Province of New Brunswick directs most of its work in international development towards La Francophonie, focussing on long-term sustainable development, capacity building and empowerment of developing societies through exchange of educational services, infrastructure development and other areas in which the province has

commercial capacity. ${ }^{496}$ In addition to these efforts the Province actively supports the work of post-secondary institutions and private sector companies who participate in international development dealings through direct staff support or participation in federal funding programs requiring "matching funds" from non-federal stakeholders.

$495 \quad$ Bourque, 2000: 40.

496 In the case of New Brunswick, international development activities are one of two types- those with immediate economic return and investment and those contributory to governance or humanitarian-related objectives such as poverty reduction, basic education, gender equality, investment in community health systems and services and sustainable development. In keeping with the consideration that financial resources are limited, "The direct involvement of the province's public service in international development projects will be supported where cost recovery is achieved through project funding and the international competencies of the involved employees are enhanced." Province of New Brunswick, International Strategy, 2003: 19. 
A good example of this kind of provincial government support for international development activities is seen in its role as a partner organizer for the $10^{\text {th }}$ Francophonie Summit in Burkina Faso. During the conference various partnerships were established, including a literacy project designed to help women in the workplace coordinated by the Bathurst campus of the New Brunswick Community College and funded by CIDA. ${ }^{497}$ By working together through the vehicle of the Province's community college, New Brunswick and Canada worked together to work towards the Burkina Faso government's 2001-2011 basic education program goal of offering "high-quality literacy services to adults (especially women and residents of disadvantaged areas) and raise the literacy rate from $22 \%$ to $40 \% . " 498$

Despite New Brunswick's small size and limited ability to engage in international development activities on a unilateral basis, it does so willingly and with specific objectives in mind unlike many larger provinces such as Ontario, where a general reticence to get involved in international assistance-related activities has been noticed. Dyment notes that although Atkey argued "of all the forms of transnational activity in which provinces might participate on their own initiative, [international development] has the greatest scope" ${ }^{, 499}$, the Government of Ontario has demonstrated a tendency "not to fully embrace the possibilities of provincial involvement."500

497 DIIR, 2004-2005 Annual Report, 2005: 24.

498 CDDA, Programming Profile for Burkina Faso: 2001-2011, Sahel and Côte d'Ivoire Program, Africa and the Middle East Branch, October 2000: 22.

$499 \quad$ Atkey cited in Dyment, 1996: 138

500 "The evidence, general speaking, shows a component government that is nudged and prodded to take-up international assistance activities; and, to the extent that it does, has done so grudgingly and largely on an ad hoc basis." (Dyment, 1996: 138) Dyment does, however, note that international assistance can be categorized as being of two 
Within La Francophonie (specifically in the North and West African regions), New Brunswick's International Strategy has stimulated participation in international development activities in sectors such as: information technology capacity-building, elearning; competency-based learning design in technical and vocational ${ }^{501}$ training (through the francophone division of the New Brunswick Community College). New Brunswick's emphasis on youth engagement, a central theme of the 1999 Sommet de la Francophonie held in Moncton, reinforces its ability to be an advocate of youth involvement in international development issues, in the hope that such partnerships will open commercial doors.

We recognize that engaging our province in international development activities strengthens societies by promoting stable government, generous social programs and free and open trade practices. This stimulates economic growth, which in turn creates trade and investment opportunities for New Brunswick in new and emerging markets. ${ }^{502}$

types: disaster relief and international development aid, and that Ontario government has ventured into international assistance/development activities where very little expense (and possibility of profit) is incurred.

501 An official at the Organization for Economic Cooperation and Development (OECD) notes, "The last decade has witnessed explosive growth in international trade in education services, particularly at the tertiary level and in specialized training fields, covering all modes of supply and involving a mosaic of institutional arrangements among a great diversity of public and private players (on their own and in combination) in developed and developing countries alike. The trade in education services is big, diverse, innovative and growing fast. It will almost certainly continue to grow as societies place an increased premium on human capital enhancement as a source of development and as a means of better equipping individuals and societies to confront, adjust to and take advantage of the demands arising from closer economic integration. The continuous upgrading of skills is increasingly seen as a key ingredient of - and perhaps a precondition for - orderly adjustment in labour and product markets." Sauvé, 2002.

502 Province of New Brunswick, International Strategy, 2003: 18. 
Benefits of a proactive international development agenda for provincial governments involving collaboration with the federal government suggest that such efforts constitute an important way to gather market intelligence and incieased visibility in regions of the world where future engagement is sought, create sustanable business relationships, improve the way international development activities take advantage of fedetal progiams and services for risk mitigation, ${ }^{503}$ and promote the province as a credible partner in global development Unfortunately, however, a quick scan of New Brunswick's global list of trading partners reveals little has been accomplished on this front, as demonstrated earlier in this chapter

\section{Other Activitzes}

Despite periodic differences between Fredericton and Ottawa on Francophonie 1ssues, the Province's International Strategy states that "The Province of New Brunswick will continue to be an active participant with Canada as a member of La Francophonie and help Canada promote its bilingual character and culturally diverse image within this important international organization "504 As such, the Province of New Brunswick hosted the Eighth Francophone Summit in Moncton in 1999 at which Member governments affirmed the OIF's steadfast commitment to preserving peace, security, protecting c1vilians and ensurng human rights This put New Brunswick squarely on the

503 For example, increase awareness and effectıve use of federal risk mitigation agencies such as Export Development Canada (EDC), Canadian Commercial Corporation (CCC) and the services of the Business Development Bank of Canada (BDC) This is to say, international development projects supported by such federal initiatıves alleviate funancial risk in addition to the services provided by regional development banks and various international financial institutions (IFIs)

504 Province of New Brunwick, 200324 
Francophonie stage, although many of the issues contained in the final summit declaration included issues related to national and international security, peace, order and good government, whose pursuit is seen to legitimate the federal government's intrusion into areas of provincial jurisdiction. ${ }^{505}$

New Brunswick's International Strategy acknowledges the value of the province's membership to La Francophonie, while at the same time recognizing that the Government of Canada has a fiduciary responsibility in international affairs to preserve and protect the interests of all provinces in foreign policy dealings. Rand Dyck captures the strategic value of this cooperation, noting that,

In recent years, the province has benefited from federal funding of bilingualism, for the more bilingual Ottawa can make New Brunswick, the less distinctive Quebec can claim to be. The federal government literally pushes New Brunswick onto the world francophone stage, such as in $\mathrm{La}$ Francophonie, an organization comprised of the world's francophone countries. $^{506}$

In conclusion of this section, New Brunswick's international policy interests as they relate to La Francophonie have been exceptionally well supported by the federal government for the overarching strategic reason of limiting Québec's claims of autonomy and proto-diplomacy on the international stage. This cooperation can be seen

$505 \quad$ Watts notes that these actions "have been the result of their founders about the prospects of potential balkanization or disintegration. The most extensive examples of such quasi-unitary powers are found in the Indian and Malaysian constitutions, but the Canadian constitution also includes some such powers (e.g. the reservation and disallowance powers; the declaratory power; and the peace, order and good government clause as interpreted by the courts." Watts, 1999: 39.

506 Rand Dyck, Provincial Politics in Canada: Towards the Turn of the Century, $3^{\text {rd }}$ edition, Prentice Hall Canada Inc., Scarborough, 1996: 175. 
in the form of cozy intergovernmental relations, Canada's support of New Brunswick's political accession to the OIF as a participating order of government, and the creation and sustenance of financial funding vehicles through which the Province pursues a range of activities that do not, on the face of it, overtly support its objectives in other action priority areas associated with the International Strategy- namely promotion of trade, investment and immigration-attraction interests. Rather, it appears that the main purpose of New Brunswick's relationship with the Government of Canada in the OIF is designed to provide political leverage for Ottawa's ongoing tension-wrought relationship with Québec.

As noted above, the generally cooperative approach adopted by the federal government and New Brunswick over participation in La Francophonie does not translate into the other two policy areas examined. In the case of trade and investment promotion, the interests of each order of government are generally synchronous and supported by the Constitutional division of powers. The financial and human resources available to each, however, leads to a disjointed approach to the overarching goal of economic development in that while the Province of New Brunswick has limited financial resources to pursue and promote regional economic development, the federal government has proportionally larger financial and organizational assets with which to pursue broad national (but not always New Brunswick-oriented) interests.

In the area of immigration the divergence of interests is even more pronounced, in that the objectives of each order of government appear to stand in stark contrast to one 
another. While the Constitution gives the provinces some degree of jurisdiction over immigration attraction functions, the federal government retains jurisdiction of issues related to Peace, Order and Good Governance, which translates into the federal government's ability to deny visa issuance and the right to enter Canada for people the Province may wish to attract. In some cases, the divergence of views has led to heated federal-provincial exchanges in $\mathrm{F} / \mathrm{P} / \mathrm{T}$, a sharp contrast to the intergovernmental fraternity endemic to La Francophonie.

The next and final chapter of this dissertation will seek to synthesize the discussion so far in relation to the four main arguments advanced in Chapter 1. 


\section{Chapter V: Analysis and Conclusion}

\section{Introduction}

The challenge of this fifth and final chapter is to ensure an effective liaison between the four hypotheses introduced in Chapter 1, the theoretical and conceptual frameworks outlined in Chapter 2; and the discussion of New Brunswick's International Strategy and international policies outlined in Chapters 3 and 4 . By returning to the fundamental questions, the arguments advanced should lend credence to the assertions made and advance our understanding of how New Brunswick's international policies and practices can be used to understand various forces that affect the study of Canadian federalism, international relations and internal provincial government policy-making.

This segment of the dissertation also relates back to the two assertions outlined near the end of Chapter 1, namely that: a) from a foundational knowledge perspective, enough room should be left for doubt, disagreement, questions and concerns such that further research agendas may be undertaken; and b) from an applied perspective, that bureaucrats responsible for the articulation of New Brunswick's intergovernmental and international policies be able to benefit from academic attention to the object of their work and gain valuable perspective on how their efforts to advance New Brunswick's international interests can be optimized in future policy development and operational undertakings.

This chapter is divided into the following sections: 
- Assessment of the International Strategy's design, implementation and evaluation

- Does size matter?

- Towards a hybridized model of province-building

- Garbage Can Modeling

- Implications regarding Canadian federalism

- Issues for future consideration

- Final remarks

\section{Assessment of the International Strategy's Design, Implementation and Evaluation}

Sound public policy should be the product of government recognizing a problem or issue facing society and putting into motion measures with which the administrative state can react to those problems or issues. This process should be deliberative, considered, and undertaken with clear objectives in mind, and ideally should not be ad hoc and done on the fly. As one provincial government employee associated with the development of the International Strategy who requested anonymity noted, "If there is anything worse than making the wrong policy or the wrong decision, it's holding on to that wrong

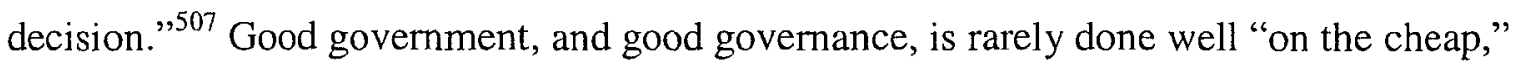
so bureaucratic mandarins and the political executive would do well to remember that public policy initiatives worth doing should be accompanied by the financial and human resources required for their implementation.

507 Anonymous, Telephone Interview, April 14, 2009. 
Neither should the design, implementation and evaluation of public policy be subject to vagaries associated with the personalization and individualization of bureaucratic decision-making. The public deserves more. Public consultations and public engagement would translate into meaningful policy and should not be conducted as a formality or façade. Central and regional governments around the world have grappled with these issues since the dawn of the legal-rational state, and in New Brunswick, historic tendencies towards nepotism, patronage, bias and politicization have presented challenges to the advent of a professional civil service dedicated to the preparation and implementation of sound public policy. Nevertheless, New Brunswick's Public Service continues to be affected by the proliferation and stiffening of informal elite configurations designed to perpetuate the advancement of interests and careers, which cast a pallor of disillusionment and disenfranchisement over public servants interviewed for this dissertation. As the same public official noted,

The International Strategy's fabric was interwoven with the advancement of individual agendas and interests, and personal commitments were made, that were not informed by government or department mandate. It was a delicate area, and we [mid-level staff] didn't know whether to correct things and point them out, or just go along with the flow. ${ }^{508}$

While there are numerous models with which to analyze public policy, ${ }^{509}$ a parsimonious approach sequentially assesses a policy's: a) conceptualization and design; b)

508 Anonymous, Telephone Interview, April 14, 2009.

509 See for example B.W. Hogwood, L.A. Gunn, Policy Analysis for the Real World, Oxford: Oxford University Press, 1984; D.C. McCool, (ed.), Public Policy Theories, Models and Concepts: An Anthology, New Jersey: Prentice-Hall, 1995; Pal, Beyond Policy Analysis, 2006; Michael Howlett, M. Ramesh; Anthony Perl, Studying Public Policy: Policy Cycles \& Policy Subsystems, $3^{\text {rd }}$ Ed., Toronto: Oxford University Press, 
implementation; and c) evaluation. In the case of New Brunswick's International Strategy, Chapter 3 has provided an overview of the process used to design the document that was tabled in the Legislative Assembly of New Brunswick, the collaborative methods leveraged to implement the 58 action priorities contained in the Strategy, and evaluation of the Strategy's implementation vis-à-vis the 2006 Progress Report. In this chapter, we will further critically evaluate the Strategy by examining aspects of each of these three elements.

While this study looked at the entirety of the International Strategy's design, implementation and evaluation, assessment of the process associated with the strategy provided particularly insightful in shedding light on the cooperative, competitive and negotiated interplay between interested parties and stakeholders. From this process evaluation perspective, it should be noted that policy evaluation is oftentimes the most under-appreciated element of public policy. ${ }^{510}$ After all, as Pal points out, evaluation "often delivers unpleasant truths, creating great temptations to shoot, or at least ignore, the messenger." ${ }^{, 511}$ In policy exercises such New Brunswick's International Strategy that rely heavily on intra and intergovernmental relationship-building, communication, collegiality and coordination, the consequences of process breakdown are substantial. In this regard, the second hypothesis advanced in Chapter 1, which argues that (although flawed) the International Strategy has functional value and should not be jettisoned, is 2009; and the case example rich study by Randy S. Clemons, Mark K. McBeth, Public Policy Praxis: A Case Approach for Understanding Policy and Analysis, $2^{\text {nd }}$ Ed., New York: Pearson Education, 2009.

510 This general point is elaborated in Chapter 1 of the Auditor General of Canada's Fall Report to the House of Commons. See Chapter 1: Evaluating the Effectiveness of Programs, Fall 2009.

511 Pal, Beyond Policy Analysis, 2006: 286. 
supported by its effect of intensifying federal-provincial communications and dialogue on international issues, as well as casting into sharper focus dysfunctionalities inherent to internal-to-New Brunswick bureaucratic interactions.

The idea that a process can yield value apart from the intended output is not new. In discussing DREE's negotiations with the Province over the General Development Agreement (GDA) in the 1970s, Savoie suggested that the process of engendering interorganizational cooperation had positive benefits.

DREE officials stressed time and again the flexibility of the GDA approach to demonstrate its viability. One senior DREE official remarked that the most positive contribution of the approach may not be the new programs it has generated, but the intergovernmental decision-making process that has been put in place. He argues that politicians in smaller provinces are compelled to look at longer-term solutions to economic development and that jurisdictional disputes with the provinces over which level of government is responsible for what can now be avoided. ${ }^{512}$

We will look at New Brunswick's International Strategy through the three policy phases of design, implementation, and evaluation.

\section{Design and Implementation}

Relying on my own experiences and drawing on interviews and conversations with numerous civil servants, it is reasonable to argue that the design of New Brunswick's International Strategy was flawed from the beginning, and given its attempt to explain

512 Donald J. Savoie, Federal-Provincial Collaboration: The Canada-New Brunswick General Development Agreement, Montreal: McGill-Queen's Press, 1981: 159. 
what the Province was already doing internationally, constituted affirmation of the status quo. Radically new directions or solutions were not advanced, nor were underlying assumptions regarding the historically subordinate role that New Brunswick assumes when in the federal presence brought into question despite bureaucrats' recognition that the Province needed to pay attention to federal tendencies towards jurisdictional creep, ${ }^{513}$ a tendency that has historical precedent since the JCPC hearings of the 1930s.

But this inconsequentiality and disconnect between the International Strategy and New Brunswick's actual international challenges and issues does not easily reconcile with even the most rudimentary agenda-setting modeling.

Howlett, Ramesh and Perl note that the agenda-setting imperative is the most critical stage of the policy cycle, and influences the entire policy consideration cycle and processes that follow. ${ }^{514}$ Citing Baumgartner and Jones' work, they note that, "At its most basic, agenda-setting is about the recognition of some subject as a problem requiring further government attention. ${ }^{, 515}$ Key policy solutions and their corresponding problems, however, are noted to have been developed within the New Brunswick bureaucracy by a concentrated group of actors and limited-constituency groups which essentially prevented input from the broader intra-governmental policy community to meaningful input,

\section{See Chapter 1.}

514 Howlett, Ramesh, Perl, Studying Public Policy, 2009: 92.

515 Howlett, Ramesh, Perl, Studying Public Policy, 2009: 92, citing Frank R. Baumgartner, Bryan D. Jones, "Agenda Dynamics and Policy Subsystems," Journal of Politics, Vol. 53, No. 4, 1991: 1044-1074. 
underscoring what Baumgartner and Jones call policy monopolization. ${ }^{516}$ While public input may have been sought, it can perhaps more accurately be seen as a public relations measure whose objective is to allow the government to plausibly say it engaged public feedback in the development and implementation of the International Strategy.

Even in policy areas where New Brunswick's experiences constituted a unique area of opportunity and provincial competence, such as its relationship with La Francophonie, few deviations from the status quo were proposed in the design of the International Strategy. Whether this was a function of there being no new financial resources being attached to the International Strategy can be assumed, but not proven conclusively. Prior to the tabling of New Brunswick's International Strategy, the Francophonie section of IGA developed a Francophonie Action Plan in consultation with external CSOs and federal stakeholders. This plan required budgetary allocation for implementation above and beyond financial resources contained in the Canada-New Brunswick Francophonie Agreement, and was pushed as a spin-off of the International Strategy despite the fact that it was completed before the first draft of the International Strategy was even developed. Moreover, this Francophonie Action plan called for new budgetary resources for its implementation, even after it was known that there would be no stand-alone budgetary consideration, a move for which no definitive answer was provided by officials to whom this question was posed.

$516 \quad$ See Frank Baumgartner, Bryan D. Jones, Agendas and Instability in American Politics, Chicago: University of Chicago Press, 1993. 
In retrospect, the International Strategy appeared to be a vehicle through which IGA recommitted the Province to international activities it was already doing. Ironically, the Province was also failing to meet many of the targets it had set itself in these policy areas, i.e. diversifying trade, increasing investment, facilitating wholesale growth of the provincial population through inwards immigration). This aspect of the International Strategy's design is discussed to greater detail in the section dealing with GCM.

Implementation of the International Strategy was not a smoother proposition than its design. As demonstrated in Chapter 3, and later discussed in the section dealing with GCM, IGA's belief that the International Strategy could be corporately implemented without stand-alone human or financial resources was misled. One official noted,

The original Terms of Reference for the International Strategy specified that it would be accomplished within existing budgets. Without resources it doesn't have a good chance of success. We will either have to drop priorities or get some money, but we can't do both; i.e, something with nothing. ${ }^{517}$

As such, it appears that the discussion of the International Strategy's implementation is somewhat truncated here.

\section{Evaluation}

Program evaluation of the success or failure of the International Strategy's implementation can take on three directions that Pal categorizes as: a) Impact evaluation-

517 Anonymous, Interview, Fredericton, March 31, 2009. 
did the program have the intended effects? If not why? b) Process evaluation- what are the components of the program? How is the program delivered? and (c) Efficiency evaluation- what was the ratio of benefits to costs in this program? Given what was spent, did we get the most out of $\left.\mathrm{It}^{7}\right)^{518}$ This section will examine the first two components of this thiee-part evaluation model, and omits the third component given the New Brunswick government's decision not to seek new program funding for implementation of the Internatıonal Strategy through Board of Management Committee of Cabınet

\section{Impact Analysis}

While the International Strategy had a marginal to nil effect as reflected by key indicators of progress related to monitoring the efficacy of trade, investment and immigration activities outlined in Chapter 4, it provided a valuable tool and causal chain with which the Province could relate to and work with the federal government, as evidenced by joint initiatıves such as the NBIDO, planned IBS and partnerships in foreign market exploration efforts such as in India In this respect, the International Strategy's inherent value should be seen not in terms of the execution of the so-called action priorities, but rather, in the intergovernmental relationships its existence helped promulgate, propagate and perpetuate

Without the International Strategy in hand as a formal 1teration of the Province's international interests, IGA had difficulties engaging support for priorities that were not codified Whether the International Strategy represented new initiatives or simply $518 \quad$ Pal, Beyond Policy Analys1s, 2006 290, see 285-328 
rehashed existing interests, the actual physical document stimulated intergovernmental dialogue and enhanced coordination of activities, as well as reinforced the government's symbolic commitment to an international policy.

Process Analysis

Given the intensity of the consultative and intergovernmental relations involved in the design, implementation and evaluation of New Brunswick's International Strategy, there is tremendous inherent value to focusing on process evaluation. Process evaluation does not seek to discuss what was accomplished by a strategy or policy, but rather the extent to which the process of implementation affected or influenced the concerned actors and the means by which policy translated into practice. As M.Q. Patton points out in his volume on qualitative research and evaluation methods, "A focus on process involves looking at how something happens rather than or in addition to examining outputs and outcomes."

As importantly, Patton notes that process orientation can be a salient factor if members and participants feel "what is happening is given as much attention as the results achieved." He points out that when process evaluation is given enhanced attention,

The journey, not the destination, is what matters [...] a planning process for a community or organization may be carried out with a heavy emphasis on participation and involvement such that building relationships and mutual understandings along the way is at least as important as the focus of the actual plan produced. The process, in such a case, becomes the outcome. That is, producing a plan (the apparent intended outcome) 
actually becomes a means to building community (the real desired outcome). ${ }^{519}$

From this perspective, we can discern a sharp bifurcation between the International Strategy's effect on IGA's relationship with line departments within the New Brunswick government, and between the Province and the Government of Canada. In the first instance, factors such as the loss of trust experienced between ISWG members and line departments and IGA as lead coordinator of the International Strategy was highly negative, and in the end, trusting relationships that had grown between central agency and line departments with interests in international relations deteriorated significantly. By the end of the second Lord mandate in 2006 , IGA had lost nearly all of its credibility for eliciting partnership and collaborative action within the provincial government system through voluntary partnership and collaborative relationship-building, and instead had to rely on more formal techniques such as Premier and Ministerial mandate, formal intragovernmental Memoranda and other coercive measures like adherence to the International Travel Advisory process. Machinations surrounding the politics of the ITA quantify this trend.

While it is suggested that the International Strategy's implementation resulted in the breakdown of relations between agencies within government, such an argument may not appear consistent with the observation that elite patterns in the bureaucracy also existed. On this point it should be noted that while elite patterns persisted, the corporate reach and interconnected of those linkages on international matters fragmented. Indeed, fiefdoms

519 Michael Quinn Patton, Qualitative Research and Evaluation Methods, $3^{\text {rd }}$ ed., California: Sage, 2002: 159. 
within departments remained, and fiefdoms dealt with other fiefdoms across government, however, corporatism on activities related to pursuing the Province's interests outside of Canada was all but eliminated.

On the other hand, the process of developing the International Strategy, pursuing its communication and implementation (status quo or not) in cooperation with the federal government through DFAIT (which played a very helpful and positive role in coordinating meetings, organizing the New Brunswick International Day in Ottawa (NBIDO) event and visiting New Brunswick for policy consultations) opened the door to cooperative dialogue between the two orders of government. New Brunswick had a vested interest to work in partnership with the federal government on a wide range of issues given the pathology of its small size, dependency and lack of resources to pursue its interests in a wholly unilateral fashion. The focus and goodwill brought by the International Strategy resulted in initiatives such as the NBDO, planned IBS and perpetuation of cost-sharing initiatives such as ACOA support for New Brunswick's market exploration activities in India, TCA and TTNB. Through this process, the relationship between IGA and DFAIT's CFP division in particular grew stronger and was leveraged as an intergovernmental point between the Province and Government of Canada that could assist in non-political, sectorally-oriented intergovernmental matters.

Not surprisingly, the bifurcation mentioned above resulted in the New Brunswick International Strategy being seen in a positive light in the Province's relationship with 
external stakeholders, and in a negative light in IGA's relationship with intragovernmental stakeholders.

Admittedly, we should not overstate the benefits of the process alone; "process evaluation is clearly linked to implementation and can be thought of as the evaluation of implementation procedures." ${ }^{250}$ It takes a critical look at the quality of value of a program minus consideration of outcomes and costs, and might consider a policy's content, implementation modus operandi, or any other features that may influence its outcome. ${ }^{521}$ By this measure, it is less clear what the net benefits of the International Strategy were, if there were any.

The process employed by IGA to implement the International Strategy was negatively impacted by the deterioration of relations between it and the line departments whose cooperation was required to implement the action priorities outlined in the strategy. To an extent, IGA's efforts to coordinate implementation of the International Strategy were moot, as the majority of action priorities in the International Strategy did not deviate too much from existing department mandates. In this light, the voluntary self-assignment of the 58 action priorities that IGA hoped line departments would undertake was a fait accompli.

The real challenge would be to get bureaucratic buy-in and cooperation to assign action priorities that did not represent existing activities of departments, and for which no stand$520 \quad$ Pal, Beyond Public Policy, 2006: 299.

521 E. Jane Davidson, Evaluation Methodology Basics: The Nuts and Bolts of Sound Evaluation, Sage, 2004: 56. 
alone financing would be provided. Case in point- the International Business Symposium was included in the International Strategy and announced as a follow-up event to the NBIDO. Despite the inherent focus on business and relationship of this initiative with $\mathrm{BNB}$, officials from that department were not quick on the uptake in claiming ownership of the priority as its source was undetermined. One official who worked closely with the ISWG and BNB who requested anonymity noted,

I didn't know what the International Business Symposium was about. It was never brought up at the International Strategy Working Group meetings. If it wasn't brought up by Business New Brunswick or the Working Group, then who? And, why should Business New Brunswick be responsible for implementing it? ? $^{52}$

From 2002 to 2006, the relationship between IGA and line departments that were involved in the implementation of the International Strategy deteriorated and were marked by reluctant cooperation in the ISWG, IGA frustration with departments who would not proactively and voluntarily implement policies in their areas of competence, and growing mistrust between line departments and IGA resulting in increased siloization of government.

As a small province that sought to pursue its paradiplomatic interests in collaboration with the federal government, New Brunswick lacked the size and jurisdictional magnitude to have its international policies and strategies assessed and evaluated. The work done by Denis Stairs on Newfoundland and Labrador's place in the federation as it relates to foreign policy was a rare exception rather than commonplace, and the lack of 
think tanks, arm's length policy oversight organizations and an effective, independent media make it difficult to introduce outside scrutiny to the International Strategy implementation process. Québec's international policies, by contrast, attracted far greater attention from some of the afore-mentioned actors given its emphasis on autonomy, its size, and willingness to challenge the federal government's desire to be the dominant Canadian voice in international intergovernmental relations. As a result, and per the International Strategy commitment to provide a report card on the implementation of the Strategy, IGA coordinated the Province's execution of the 58 action priorities. In essence, government sought to evaluate its own work, a messy proposition at the best of times and in the best of circumstances, on account of the lack of other alternative assessors or evaluators. Indeed, it is instructive that the Province's flagship university and oldest incorporate university in Canada, the University of New Brunswick, has no effectively functioning International Relations program in its Political Science faculty.

\section{Does Size Matter?}

New Brunswick's small size has undoubtedly constituted one of its greatest impediments with regards to its pursuit of international interests, and has not played as great a positive role as had been hoped early in the International Strategy development process, namely that small size would result in greater intra-organizational coherence, collaboration and coordination. In terms of operational efficacy, there are ample examples presented in this dissertation that demonstrate that the Province's ability to pursue in-country trade representation like Ontario, or promote its immigration interests in locations in which it 
has competitive advantages, such as francophone countries, like Québec, are hampered by its paucity of expendable human and financial resources. In this dual sense, New Brunswick's size has a double-edge- on one hand and in theory, it facilitates organization and coordination of efforts. On the other hand, however, this small size encourages and to some extent operationalizes an unchecked elite cadre that creates, sustains and perpetuates government processes that support a wide variety of international interests that may or may not support the International Strategy.

Despite this lack of resources, however, New Brunswick demonstrates a historic predilection towards pursuing self interest in the tradition of rational actor modelmaximization of collaborative relations with the federal government by positioning itself to be used by Canada to offset Québec in La Francophonie, and engage in joint intercultural awareness training and promotional trade activities with the federal government vis-à-vis the TCA model. Whereas New Brunswick has scant finances to support its international interests, its agreement with DFAIT to support its participation in La Francophonie leaves IGA's FOLB in the enviable position of having to spend approximately $\$ 1$ million every two years. This incredible spending power comes with very little by way of federal conditionality on spending attached to fund disbursal, thus allowing the Province incredible leeway in its participation in the international Francophonie. 
Again, a sharp bifurcation can be seen between New Brunswick's well-funded but commercial questionable membership to La Francophonie, and the scant resources dedicated towards the Province's goal of "prospering in a global community."

Size in the Future

Ultimately, what effect will New Brunswick's small size have on its international prospects? The answer to this question continues to be elusive and defy any definitive answering. It may be that New Brunswick has (by chance or circumstance) been able to translate its small size into some obvious concessions vis-à-vis its participation in $L a$ Francophonie. Nevertheless, small size has not meant increased internal organizational coherency, clear leadership or harmonization of policy direction and bureaucratic performance. Instead, New Brunswick's small size has turned into a cliché that is noted as an asset, but has little resulted in little success outside partnership with the Government of Canada to limit Québec's autonomy within La Francophonie.

Canadian federalism has undergone tremendous change over the past 130 years, ${ }^{523}$ and tracing this evolution can help predict what the future of federal-provincial relations may look like in the future. Brown points out evolutionary patterns of federalism may mean that,

523 Brown notes a series of phases of Canadian federalism: 1867-85 early consolidation and centralization; $1885-1911$ provincial rights and increasing national autonomy; 1911-26 war and de facto independence; 1930-39 Depression; 1939-45 war again; 1945-70 build-up of the welfare state; 1970-90 growing fiscal and economic power of the provinces. 
One cannot predict the nature of the next era-- say by 2020 -except to say that it will likely differ significantly from our own. From the perspective of the federal regime, the long historical view reinforces an assessment of Canadian federalism as able to adapt to sharp changes in the governing environment $[\ldots]$ the future will bring its own challenges the shape of which we may be just discerning. ${ }^{524}$

Depending on which direction those changes will take place, smaller provinces may find that macro changes on the world stage will further loosen the already loosening grip that the federal government has over the conduct of Canada's international relations policy. In light of Roy's assertion that provinces should have increased autonomy (if not sovereignty), in areas of their exclusive sovereignty, in May 2006 the Government of Canada announced that the Province of Québec would receive special status as part of Canada's delegation to the Paris-based United Nations Education, Science and Culture Organization (UNESCO). This dispensation would include the ability of full, formal and direct participation, "in response to the province's demands for a more direct role in negotiations on the international stage in areas that affect provincial jurisdiction, such as culture and language." ${ }^{25}$ The danger to smaller provinces, however, is that the federal government appears destined to continue holding the purse strings and resources needed by small provinces.

Unfortunately for those of a centralist bent, however, the federal spending power is far more significant when dealing with the have-not provinces than it is when dealing with the wealthier provinces. The bargaining process at the root of cooperative federalism is, thus, not only one-sided in

524 Brown, 1999: 18.

525 CTV National News, "Harper Announces UNESCO deal with Québec," May 5, 2006. URL: http://www.ctv.ca, Accessed: May 6, 2006. 
favour of the federal level but it is also quite asymmetrical in its effect on the various provinces. ${ }^{526}$

As researchers in other small Canadian provinces and regional government in federations around the world pay increasing attention to the role that small regional units of federal systems might play in international affairs, the net effect on cooperative and competitive federalism, and methods to deal with inter-jurisdictional convergence, will become increasingly clear.

\section{Towards a Hybridized Model of Province-Building}

The extensive system of intergovernmental consultation built up over the years has given added support to province-building. It has become standard practice to deal with most important domestic policy issues through an extensive network of federal-provincial conferences. These conferences take place at virtually every level of federal and provincial administration. ${ }^{527}$

The theory of "province-building" discussed in Chapter 2 provides a helpful model with which to conceive of New Brunswick's international policies. Contrary to Young, Faucher and Blais' argument that the concept ought to be abandoned, New Brunswick's experiments with its international policies and paradiplomacy suggest that the concept can be revisited, recast and given new relevance as the Province tries to assert its interest

526 Richard J. Van Loon, Michael S. Whittington, The Canadian Political System: Environment, Structure and Process, ( $4^{\text {th }}$ edition), Canada: McGraw-Hill Ryerson Ltd., 1987: 512. See also Kenneth McRoberts, "Unilateralism, Bilateralism and Multilateralism," in Richard Simeon (ed.), Intergovernmental Affairs, Toronto: University of Toronto Press, 1985: 71-129.

527 Leach, "Canadian Federalism Revisited," 1984: 12. 
in pursuing areas in which it has constitutional and jurisdictional primacy on the international stage, in collaboration with the federal government.

A fundamental element of Young, Faucher and Blais' condemnation of province-building involves their identification of six basic characteristics associated with the concept, for each of which they provide a well-thought out and justified rebuttal. Nonetheless, a lot has changed over the past 25 years since the refutation was published, and the recent internationalization of areas squarely in the provincial jurisdiction justifies revisiting the concepts and principles. After all, in the 1930s the federal government challenged the provinces' jurisdiction in areas of their own competence under the pretence that international affairs were a federal responsibility. Since the wave of apparent provincebuilding in the 1960s and 1970s, the likelihood of this happening is less and less. The following pages examine several ${ }^{528}$ of Young, Faucher and Blais' critiques to the six propositions of province-building in the context of New Brunswick's international policies, upon which an alternate, hybridized view of a modern province-building theory is presented.

I do not challenge all of Young, Faucher and Blais' critiques of the six province-building propositions; in several instances they are as correct now as they were when they were first published in 1984. For example, their rebuttal to Proposition 2's insistence on improved human resource functionality (i.e. greater technical skills, size of labour pool and code of professionalism) in the provinces is especially accurate when applied to New Brunswick's human resource capability as it relates to federal government expertise at 528 Young, Faucher, Blais, “The Concept of Province-Building," 1984: 790-794. 
DFAIT in terms of baseline competency to work effectively in international markets. However, I will focus on three propositions where I disagree with their assessment.

Proposition 1-Provincial Resistance to Federal Incursions

In the section dealing with province-building in Chapter 2 , it was noted that one key principle involves staunch provincial resistance to federal incursions into areas of their jurisdiction $^{529}$, and an increase of self-serving demands on Ottawa. We can reasonably extrapolate this proposition to also include provincial opposition to federal opposition to provincial initiatives where provinces have constitutional jurisdiction that rely on federal cooperation, and equate federal intransigence and uncooperativeness as trampling provincial rights in areas in which they have the right to pursue their interests.

For example, although Canadian provinces have jurisdiction in the promotion of immigration, they are functionally and effectively prevented from acting within the bounds of their jurisdiction given the federal government's POGG-derived right to deny any person entry to the country, which it has demonstrated a willingness to do. How could, for example, business immigrants legally settle in New Brunswick if they were successfully nominated under the Province's PNP program but were denied entry visas? In this way of thinking, a province's ability to administer programs and policies in areas of their jurisdiction, even if on the international front, can be blocked by the federal government.

529 Young, Faucher, Blais, "The Concept of Province-Building," 1984: 787. 
Young, Faucher and Blais note that in several fields of social policy federal incursions into areas of provincial jurisdiction are accepted, and that in some social fields, "jurisdictional docility is very evident, especially among the weaker provinces," $" 530$ and point out that New Brunswick was willing to accept federal funding for, and influence over, the construction of elementary and secondary schools. During the Lord administration, however, this weakness did not translate into the kind of jurisdictional docility Young and his collaborators assign to a small and weak province like New Brunswick, neither in the Province's willingness to back down over its jurisdiction over property rights in relation to acceptance of the federal gun registry despite its headquartering in Miramichi, New Brunswick, ${ }^{531}$ or regarding jurisdiction over social programs such as national day-care program. ${ }^{532}$ While history may prove that Bernard Lord as Premier made miscalculations in various areas of policy, his government tended to assume unequivocal positions in areas in which there existed constitutionally-assigned provincial jurisdiction. ${ }^{533}$

530 Young, Faucher, Blais, “The Concept of Province-Building," 1984: 787.

531 See Samuel A. Bottomley, "Locked and Loaded: Gun Control Policy in Canada," Chapter 1 in Robert M. Campbell, Leslie A. Pal, Michael Howlett, (eds.), The Real Worlds of Canadian Politics: Cases in Process and Policy, 4th Ed., Peterborough: Broadview Press, 2004. Despite the Liberal federal government's effort to placate New Brunswick's opposition to the Gun Registry by setting up the centre in this high unemployment riding, the provincial Tories refused to allow the site selection and jobcreation decision to temper its position against it.

532 See for example, Brian Laghi, "East Coast Premiers Lobby for New Deal on Daycare Dollars," Globe and Mail, October 5, 2005: A3. While Lord did not wish to draw jurisdictional lines in the sand with the Paul Martin Liberal federal government, he disagreed with Ottawa's attempt to use the lure of federal funding to enter areas of provincial jurisdiction, notwithstanding the normative goal of providing daycare spaces for young children, as well as establish federal controls on how those dollars could be spent for all provinces except Québec for which it signed an asymmetric side deal releasing it from such conditionalities and controls.

533 Interview, Bernard Lord, Premier of New Brunswick, May 8, 2007. 
As demonstrated in the example dealing with the Province of New Brunswick's education partnership in Nagpur, India, federal jurisdiction over visa issuance through CIC resulted in 7 of 8 students involved in the pilot offering of the Modern School of India project being rejected from entry to Canada. The reaction from New Brunswick was immediate and visceral, expressed in detail at a packed-house F/P/T and public meeting on India at DFAIT headquarters which time CIC was called to task to explain why it rejected entry visas for students enrolled in a New Brunswick high school program for which a final semester in New Brunswick was required. While Young, Faucher and Blais note whereas docility varies by issue, province and ideological orientation of the provincial government, Atlantic Canada tends to demonstrate jurisdictional permeability, ostensibly suggesting that New Brunswick's position would vary depending on the policy issue, and that labeling province-building as a descriptor to varying levels of resistance to federal incursion only serves to impede the search for variation and causality. ${ }^{534}$

In the case of international education, however, there is a confluence of domestic policy, provincial program delivery, international relations and concurrent, intersecting intergovernmental jurisdiction- essentially, what advocates of "perforated sovereignty" had argued for some time already. While New Brunswick expressed its concern in a public format, it also through its Departments of Education and IGA sought to find an intergovernmental solution to the issue and protect its interests over the international articulation of a policy located squarely in its constitutionally-defined responsibilities in a collaborative fashion with the federal government.

$534 \quad$ Young, Faucher, Blais, “The Concept of Province-Building,” 1984: 790. 
In this limited sense, attaching the label of "province-building" accurately describes what New Brunswick was trying to accomplish. In a larger sense, however, the Province's de facto desire to resist federal incursions in an area in which it could not dedicate financial resources is itself telling, and suggests that the International Strategy itself can be seen as an overall attempt to formally stake its claim in extraterritorial relations, even if in collaboration with the federal government. As Cairns pointed out in 1977,

The protection of jurisdictional authority and the protection and expansion of provincial territory have been accompanied by an ever more vigorous employment of provincial legislative competence. Related to this as both cause and effect has been a concomitant increase in government personnel. A similar expansion of personnel, and a no less aggressive exploration of the limits of its constitutional responsibilities, have been displayed by the federal government. ${ }^{535}$

In this way, the International Strategy displays what Cairns describes - a province staking out its claim, seeming for the point of maintaining its ownership rather than actually exercising it.

As with the case with Proposition 1, looking back to Chapter 2 allows a view of province-building that links it with the widening scope of provincial public policy, especially in the economic realm. Young, Faucher and Blais pay homage to Cairns' observation that provinces had steadily extended themselves into unclaimed or concurrent areas of jurisdiction in relationship to the federal government. They cite Cairns' observation that provinces "work toward the creation of limited versions of a politically

535 Alan C. Cairns, "The Governments and Societies of Canadian Federalism," Canadian Journal of Political Science, Vol. 10, No. 4, December 1977: 702. 
created provincial society and economy, and the national government works toward the creation of a country-wide society and economy." 536

Young, Faucher and Blais argue, however, that advocacy concerning expansion of provincial policy are misleading, and that increased provincial expenditures can be related back to conditional grants, which ultimately "do not change provincial priorities." ${ }^{, 537}$ The basic message here is that federal assistance is what drives major changes in provincial expenditures on so-called province-building efforts, and not increased provincial investment under its own steam and to its own devices. Furthermore, they note that provincial efforts to stimulate economic growth are not new but historic pursuits, and that provincial governments may be more willing (now than in the past) to use direct measures to attain their growth objectives; and that sweeping concepts such as province-building obscures significant questions such as:

a) What sectors are provinces most preoccupied in increasing spending;

b) What instruments are they using to pursue those goals; and

c) Did this lead to conflict with Ottawa? ${ }^{538}$

Effort has been expended in Chapters 3 and 4 to demonstrate that the Province has attempted to broaden the scope and activities of departments involved in advancing New Brunswick's interests on the world stage, one of which is Business New Brunswick, the economic development arm of the province. Through the twin goals of advancing New

536 Cairns, "The Governments and Societies of Canadian Federalism," 1977: 706.

537 Young, Faucher, Blais, "The Concept of Province-Building," 1984: 795.

538 Young, Faucher, Blais, "The Concept of Province-Building," 1984: 799-800. 
Brunswick's parochial economic growth objectives of promotion of trade, attiaction of investment and facilitation of technology transfer, as well as Canada's comparable goals of trade and investment promotion, the Province has giadually modified yearly strategic plans to place greater importance on opportunity identification and acquisition in foreign matkets such as India, China, the EU and of course the US

Departmental figures, however, do not provide conclusive evidence that overall BNB funding (actual, not budgeted, expenses) for these functions has steadily incieased given the added cost of working in foreign markets. When administrative, small business and industrial development, and strategic assistance total budget expenditures incurred by the Province were calculated, they showed the following inconclusive indication of increased provincial government spending power*

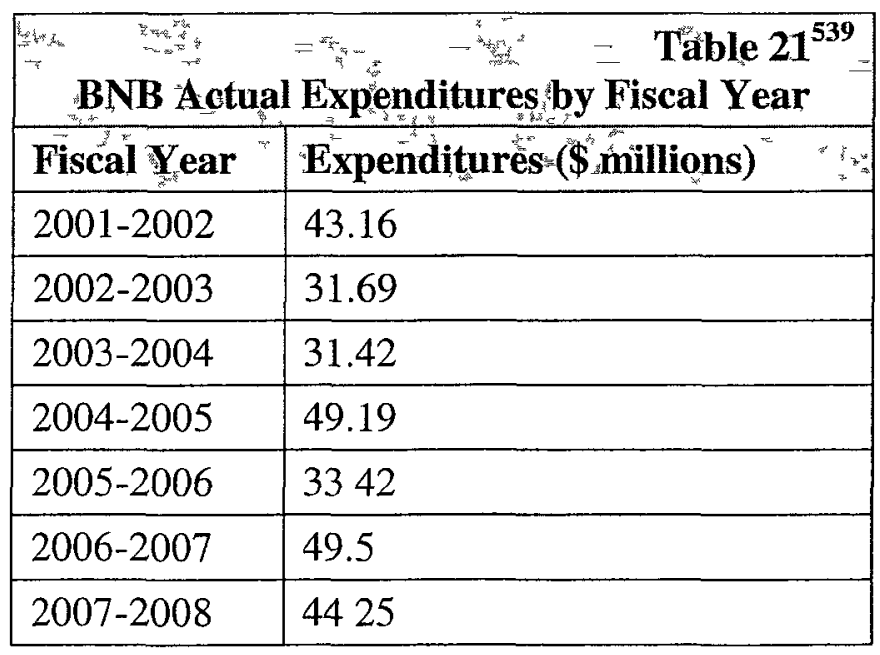


While there are few indicators that can demonstrate increased provincial expenditures in support of its growing attention on commercial expansion and growth, there are a number of collaborative federal-provincial vehicles in which shared federal-provincial funding is being used to support provincially-determined objectives, such as the TCA missions, TTNB and ad hoc activities such exploration of the Indian market through shared federalprovincial partnerships and strategic reallocations of existing provincial budgets to pursue new opportunities.

In this third and last examination of Young, Faucher and Blais' critique of the provincebuilding concept, attention is drawn to the proposition that provincial governments have undergone a transformation that has increased their ability to respond to a growing and diverse range of social, economic and political interests, they have demonstrated strong tendencies towards centralization, and have effectively replicated federal government features such as central agencies, cabinet committees, and elaborate control systems to guide and shape the handling and management of complexified policy formations. The ITA discussed in Chapter 3 is a good example of this kind of planning system shift.

The critique provided by Young, Faucher and Blais regarding the centralization of provincial policy, however, raises the argument that in order to be effective, "planning groups and agencies must persuade other bureaucratic units to accept their formulations." 540 They further note that central planning units face challenges when exerting suasion over line departments, and that policy implementation poses problems for provinces because change can be resisted by intra-bureaucratic organizations who 540 Young, Faucher, Blais, “The Concept of Province-Building," 1984: 802. 
may be at schismatic odds with the central agency responsible for corporate delivery of the initiative or policy in question. ${ }^{541}$

They conclude with the thought-provoking observation that "given the paucity of studies of the normal functioning of provincial governments, policy coherence may have been noticed most when their projects have collided with those of the central government- - but this will occur precisely when some coherence has been achieved."

Despite the challenges that are inherent to the International Strategy's internal consistency and rationality, IGA as the central agency most responsible for the management of New Brunswick's International Strategy was extremely efficacious in the administration and discharge of its duties, whether at the beginning by voluntary cooptation and encouragement of corporate voluntarism on the ISWG, or at the end when line departments were less willing to cooperate with IGA but continued to work towards and in compliance with the International Strategy and its associated protocols under directive of the Premier and or his Ministers.

The policy coherence Young, Faucher and Blais allude to is less of a factor with respect to provincial paradiplomacy, in that New Brunswick's purported International Strategy coherence never sought to displace, challenge or subvert federal prerogative over foreign policy and international relations. In fact, despite its incoherence, the International Strategy openly acknowledged federal policy jurisdiction over international affairs, and

541 Young, Faucher, Blais, "The Concept of Province-Building," 1984: 803-804.

542 Young, Faucher, Blais, "The Concept of Province-Building," 1984: 804. 
sought to build New Brunswick's capacity for international action through co-optive and collaborative engagement with the federal government. In conclusion, the provincebuilding arguments advanced by Young, Faucher and Blais still have currency, and retain their relevance when modified and applied to New Brunswick's international policy efforts. In the following several paragraphs, I argue that a hybridized province-building model should be pursued by the Province of New Brunswick.

\section{A Hybridized Province-Building Model}

A modern and hybrid province-building model would have as its central organizing principle the notion that province-building need not be a wholly competitive, dog-eat-dog proposition, but rather, one that places a premium on balancing collaboration and cooperation with pursuit of self interest and interest articulation, a position advanced by Urquhart cited in Young, Faucher and Blais' argument. Since Confederation the notion of provincial capacity-building (whether on the domestic or international front) is seen by the provinces and federal government as a relative process where gains by one jurisdiction are a loss by another. While this argument has an alluring logic to it, it overstates the conflict between provinces and between the provinces and federal government. Moreover, in a modern globalized international political economy, it unnecessarily diminishes the importance of intergovernmental collaboration in promoting paradiplomacy. 
If this dialogue was solely concerned with province-building in a national context the arguments advanced by Young, Faucher and Blais would be difficult to refute. With the rise in provincial paradiplomatic activities in Canada, however, there is new relevance to the notion of province-building, especially since areas of provincial such as education, health, trade, investment and commerce, immigration and even the environment are becoming internationalized and are coming to the attention of DFAIT. In this way, province-building can be seen as the reincarnation of the old trend of stiffened provincial resistance and capacity-building to retain autonomy in areas of their own jurisdiction, with the notable difference being that this power rebalancing dynamic is happening outside rather than inside the nation-state. Nevertheless, despite the insistence of Québec for foreign policy autonomy, New Brunswick has yet to adopt a hostile or poweraggrandizing role in its relationship with Ottawa over foreign relations, and has favoured engaging in province-building through more collaborative mechanisms.

While Young, Faucher and Blais argue that "the concept inflates normal provincial efforts to preserve their areas of jurisdiction and to enhance their resources," and that the "Maritimes' blustering subordination" cannot reasonably be equated with "Ontario's fundamentally ambivalent role in the federation" and "Newfoundland's desperate optimism," ${ }^{, 53}$ on the international front it appears that all three provinces have comparable self interests, a commitment to work with and leverage resources from the federal government, a willingness to shift coordinative functions towards empowered central agencies, and reflect those functions in the form of policy White Papers such as New Brunswick's International Strategy.

543 Young, Faucher, Blais, "The Concept of Province-Building," 1984: 814. 
Province-building in this global context need not be associated with conflict between regional and central government, nor with anti-federalism. After all, in international relations provincial governments such as New Brunswick have more to gain when they work in cooperation with the federal government than against it or in competition with it. In this sense it is argued that the notion of province-building has value, and relevance in assessing New Brunswick's paradiplomatic activities, and requires further academic attention.

\section{Garbage Can Modeling}

This section revisits the assertion previously advanced that the Garbage Can Model of public policy-making provides a useful tool through which to understand New Brunswick's International Strategy. As the fourth hypothesis advanced in Chapter 1 maintained, New Brunswick's International Strategy development, implementation and evaluation reflect qualities that defy logic, especially if we apply theories of pluralism, public choice and rational actor theory. While it would be erroneous to say that the entire International Strategy lacked the policy coherence expected of a major government initiative, irrationalities that were detected suggest weaknesses in the design-toevaluation spectrum.

Exploration and application of the GCM model does not mean conventional approaches that could have been employed do not hold water, or lack explanatory power. Rather, the lack of a rigid methodological orthodoxy as related to this dissertation topic affords a 
certain intellectual and poetsc license for conceptual unorthodoxy In this sense, while this section of this Chapte1 discusses how GCM 1s relevant to this consideration of New Brunswick's international policies, it also plays a devil's advocate function by exploring how pluralısm and ratıonal actor theory may also play an 1llumınatıve role, in that what were seemingly irrational moves and decisions by IGA were in reality highly calculated moves The following few pages will review what we can learn from these alternative approaches to GCM

\section{Pluralısm}

In the case of the pluralist ${ }^{544}$ model, an emphasis is placed on policy development through the imputation of interests by a broad range of actors from within the bureaucratıc framework as well as civil society at large ${ }^{545}$ As Pal notes, government has attempted to consult and engage the public as a way to address the decreased fath that c1tizens have in their governance structures, as well as to serve an instrumental function (by tapping into their knowledge, experience and expertıse) and legitımatıng functıon. ${ }^{546}$ But more than promoting broad-based engagement, pluralıst approaches sought to play a role in managing intra-governmental and bureaucratic actors' urges for a place at the

544 See Wrlliam E Connolly, Samuel Allen Chambers, Terrell Carver, (eds), Democracy, Pluralısm and Political Theory, Routledge, 2008

545 "The Province of New Brunswick recognizes the benefits of forging meaningful partnerships with business, communities, academia, stakeholders and other levels of government in pursuing our international interests We are committed to strengthening our traditional relationships and building new alliances and partnership opportunities Collaborative action is a stiategic choice for the Province of New Brunswick "Province of New Brunswick, New Brunswick's International Strategy, 2003 8-10

546 Pal, Beyond Public Policy, 2006266 
International Strategy design table that would afford the chance for participation and meaningful input.

In this view, the Province's International Strategy would, in theory, be the product of a two-tier competitive process to be heard; the first being between the Province and external stakeholders such as the federal government, provincial businesses, academic community and ethno-cultural organizations, the second being within the provincial government in the form of:

a) Interdepartmental negotiations with departments as equals;

b) Between line departments (with larger budget allocations for delivery of programs or extension of services to the public) and central agencies (whose policy coordinative mandates have far-reaching horizontal reach but comparatively meagre spending prerogative); and

c) By elites in central agencies and/or line departments who sought to carry on the guise of participatory policy development while at the same time unilaterally advancing their own ideas on what the Strategy should look like, thereby revealing hitherto latent and hidden lines of vertical hierarchy and bureaucratic stratification.

With respect to these three points, development of the International Strategy involved months of consultations with provincial businesses, community and ethno-cultural groups, municipalities, representatives of the federal government, 3 of the 4 provincial 
universities and various members of civil society at large who had a vested interest in the New Brunswick's international activities over the summer and fall of 2002. The ISWG also held to an aggressive calendar of meetings in order to develop the rough framework of the International Strategy, including development of its action priorities. As for the notion that elites within IGA would incorporate both streams of input into the International Strategy, serious concerns were raised as to whether the final strategic document that would be submitted to the Planning and Priorities Committee of Cabinet would be reflective of these broad-based negotiations and consultations, and that central agency actors did not have a strategy "canned" and ready in their figurative back-pocket. One provincial government official closely associated with the work of the ISWG as well as implementation of the International Strategy recollected,

Everybody who was asked to join the ISWG did so with scepticism, like this was going to be just another committee where central agency wouldn't take our advice and wouldn't listen to our input. Individuals at the meeting table didn't think that their recommendations would be incorporated into the International Strategy, and that decisions had already been made on the second floor ${ }^{547}$ as to what it would look like. In any event, IGA assured the ISWG that its input would be reflected. ${ }^{548}$

The competing and collaborating tendencies of bureaucratic positioning to collectively influence the International Strategy, however, have implications at the intersection of: how broad-based consultations are reflected in policy; elites position themselves as policy development gatekeepers; and small provinces predisposed are susceptible to having their policy undertakings become highly personalized by bureaucrats. Regarding

547 Premier's Office and IGA are located on the second floor of the Centennial Building in Fredericton.

548 Anonymous, Interview, Fredericton, March 31, 2009. 
this last point, White points out that smaller bureaucracies and tendencies to overcentralization and personalization of policy results leads to a diminution of policy efficacy.

Smaller scale in bureaucracy may mean more personal fiefdoms; more idiosyncratic, unpredictable behaviour, which in turn may reduce morale and effectiveness; and less scope for change because of rigidity and the top reflecting the influence of a small, closed elite. Taken in concert with the narrower range of expertise and resources available in smaller bureaucracies, such size-related factors make for far less effective, less manageable bureaucracies. ${ }^{549}$

White's observation is particularly relevant when considered in the light an anonymous government official's observations regarding the work of the ISWG,

Once reassured that their input would be included in the International Strategy, the ISWG worked cooperatively up to the time that the final draft was given to the Deputy Minister of IGA. Then the process went completely sideways. The draft that ended up moving forward was different than what the committee had wanted. Sure there may have been mistakes in the Strategy, but if it had been allowed to run its course there would have been more buy-in from stakeholders. Essentially, the agenda was hijacked, and the prior genuine interest by participants to make it happen disappeared. One individual, not IGA as a whole, may have hijacked the final report when the ISWG's work was about $2 / 3$ the way through its work, a person who lacked the expertise to make good policy. If this person had the expertise [he/she] should have sat down with the ISWG instead of rewriting the strategy. ${ }^{550}$

549 Graham White, "Big is Different From Little: On Taking Size Seriously," Canadian Public Administration, 33, Winter 1990: 527-534.

$550 \quad$ Anonymous, Interview, Fredericton, March 31, 2009. 
Deviations from the ISWG to the Legislature

For all the critical comments made about the deviation of the International Strategy from what the ISWG suggested to the final product, what were the changed items? Were they slight grammar modifications and inflected phrases reworded to account for political sensitivities and strategic interests beyond the International Strategy but related to the Province's overall interests, or were they significant additions that were not based on research, need or fact, but rather "wish list" items? Confidential discussions with ISWG members revealed two (among other) major structural shifts that ran counter to the desire of the ISWG.

First, the ISWG dedicated considerable thought into sectors of activity in which the Province had capabilities, and conscientiously chose not to make specific geographic markets that it would target. It was felt at the time that emphasis on core areas of provincial competency and/or need should be emphasized, and that focusing corporate efforts and attention on certain regions would discourage or prevent departments from pursuing their interests in countries that were not on that list. Moreover, if the Province was attempting to use its International Strategy as a formal means to communicate its priorities to DFAIT and the federal government at large, to what extent would the federal government be predisposed to assisting provincial initiatives in countries that were not listed in the International Strategy as priorities? 
Somewhere between the ISWG drafting table and the tabling of the International Strategy in the Legislative Assembly, it was determined that the U.S., nations of La Francophonie (with emphasis on France), Asia (with emphasis on China and Japan), the U.K., Germany, Mexico and Eastern Europe, would be flagged as Designated Target Markets. ${ }^{551}$ The International Strategy noted that, "The Province of New Brunswick will target a limited number of geographic markets for an enhanced level of focus and corporate effort ${ }^{\prime \prime 52}$ despite the strong insistence from the ISWG members that identification of one country as a target over another would detract from individual departmental interests in regions that may not show up on that list. As an official simply shrugged when asked about the rationale for the selection of various countries and continents for targeting, "Why did they [meaning IGA] want to go there? I don't get it. ${ }^{, 553}$

So in the end, why were these markets selected? Was it to provide politicians with an easy answer to the question of "where" the International Strategy would take the Province? Or, were there other bureaucratic or personal interests that were being served?

A second major addition to the International Strategy was the wholesale inclusion of "International Environmental Stewardship," a move that surprised many ISWG members given that the Department of Environment was not a member of the ISWG. This policy area is discussed in the section of this Chapter that discusses the connection between Garbage Can Model and the Province's International Environmental policies.

551 Province of New Brunswick, International Strategy, 2003: 22-23.

552 Province of New Brunswick, International Strategy, 2003: 22.

553 Anonymous, Interview, Fredericton, March 31, 2009. 


\section{The Value of Participation}

The lack of meaningful engagement between the Province and non-governmental stakeholders leaves out a key element of the pluralist model. Here Patton's warning to engage active participation in policy inquiry, development and articulation is valuable, in that he notes engaged policy stakeholders take ownership of policy processes and implementation because they perceive a vested stake in the exercise. Given the real (or perceived) organizational hierarchy between IGA as central agency and line departments, breaking down the impression of super-ordinate and sub-ordinate is important. He notes,

Participatory evaluation is bottom-up. The trick is to make sure that participation is genuine and authentic, not just token or rhetorical, especially in participative evaluation, where differing political and stakeholder agendas often compete. ${ }^{554}$

The significance of this argument is readily visible in the detachment of public servants from the implementation of the International Strategy. My interviews with civil servants associated with the International Strategy revealed deep concerns over the personalization of policy development, lack of coherence of the strategy, and a high degree of reluctance to speak (on or off the record). With respect to interdepartmental power dynamics in the policy development process, an overwhelming majority of comments from across the line department spectrum related to the intense sense of disenfranchisement and disempowerment that provincial government officials felt when dealing with IGA, and the frustration of seeing policy commitments advanced that represented central agency,

554 Patton, Qualitative Research and Evaluation Methods, 2002: 184 citing Fricke and Gill, 1989. 
versus line department, interests with respect to the International Strategy. Robert Mandel points out, "If the government is small and highly centralized, then daredevil irrationality seems more likely among the top leaders because of the absence of checks and balances or input from below and the exclusive significance of the whims of the autocrat [... $]^{3555}$

By extension, this dissertation suggests much of New Brunswick's International Strategy is comprised of policy assumptions that are demonstrative of the work of a small clutch of officials in central agency operating in an environment in which their input is not called into question by other central agencies or line departments, solid theory, research or discovered fact. As part of an ongoing research agenda this aspect of the central agency -line department relationship provides fodder for future research, as it remains an argument not systematically or thoroughly advanced in this dissertation..$^{556}$

555 Robert Mandel, "The Desirability of Irrationality in Foreign Policy Making: A Preliminary Theoretical Analysis," Political Psychology, Vol. 5, No. 4, December 1984: 650 citing J. Frankel, The Making of Foreign Policy: An Analysis of Decision Making, London: Oxford University Press, 1963: 169.

556 Elite theory provides valuable context for such future undertakings. Note "Public policy does not reflect demands 'of the people' so much as it reflects the interests and values of elites. Changes and innovations in public policies come about when elites redefine their own values. However, the general conservatism of elites-that is, their interest in preserving the system-means that changes in public policies will be incremental rather than revolutionary. Public policies are often modified but seldom replaced." Thomas Dye, Harmon Zeigler, "The Irony of Democracy," in Eva EtzioniHalevy, (ed.), Classes and Elites in Democracy and Democratization: A Collection of Readings, New York: Garland Publishing, Inc., 1997: 156. For a fuller understanding of elite theory, see Ettore Albertoni's work on Gaetano Mosca's writings on elite theory, Mosca and the Theory of Elitism, Oxford: Blackwell, 1987, and Richard P. Bellamy, Modern Italian Social Theory: Ideology and Politics from Pareto to the Present, Cambridge: Polity, 1987, and Gaetano Mosca's translated work, The Ruling Class, New York: McGraw-Hill, 1939. 
Public Choice Theory

Public choice approaches encourage conceptualization of policy decision-making as an expression of pursuit of self-interest and self-maximization. Drawing from use of the theory in classical liberal economics, the individual is seen in decision-making as if in a market-oriented environment where choices are made in strategic, highly rationalized ways. Mueller notes that public choice can be defined as "the economic study of nonmarket decision making, or simply the application of economics to political science [and that man] is an egoistic, rational, utility maximizer." ${ }^{357}$ As applied to political science, public choice theory involves the following principles that establish individual choice as the basis of: organizational or collective actions; rules to provide stability in a process or system; satisficing rather than maximizing strategies by individuals in pursuit of their self interests; and incremental change in collective and individual decisions made in organizations. ${ }^{558}$

In terms of this dissertation, the argument that public choice theory draws our attention towards examination of government as a complex process of interactions, negotiations and trade-offs has explanatory value. Those versed in the analysis of bureaucratic decision-making will recognize there is utility in the notion that bureaucrats rationalize their support or opposition to policies "that will expand their departmental budgets,

557 Dennis C. Mueller, Public Choice III, Cambridge: Cambridge University Press, 2003: 1-2. For a good collection of papers regarding Public Choice theory, also see Dennis C. Mueller, (ed.), Perspectives on Public Choice: A Handbook, Cambridge: Cambridge University Press, 1997.

558 Michael M. Harmon, Richard T. Mayer, Organization Theory for Public Administration, USA: Little, Brown Publishing, 1986: 242-243 cited in Farazmand, 2002: 35 . 
increase the number of programs or staff under their responsibility or enhance their opportunities for promotion and influence." ${ }^{559}$ By extension, this logic can be inverted to suggest that decision-makers will also rationalize their lack of support for policies that will squander their departmental budgets, redeploy human and budgetary resources to policy commitments that do not serve the department's strategic plan, or proactively feed into strategic policy-making that establishes departmental priorities that require fulfillment but lack the dedicated budgetary allocations necessary for their implementation.

Using this line of argument, it is plausible that knowledge that IGA would not pursue or provide financial or human resources for implementation of the International Strategy would encourage line departments to propose International Strategy action priorities that were merely "rehash" of existing priorities, or policy issues for which they felt they already had the answers and or resources to advance. After all, if IGA was not bringing new resources to the table for the implementation of the solutions proposed by the International Strategy, and at the same time departments were asked to pitch solutions to issues that they dealt with, why would a rationally-acting department propose anything but the status quo? Why propose anything new? Conversely, what benefit would the ISWG participating line department realize if it provided new input and new directions that would ultimately prove to be a drain to the departmental mandate? Can it be argued that there was functional value to IGA deviating from the International Strategy draft

559 Jackson, Jackson, 2006: 510. As the Province's decision-making processes are examined in light of the GCM, the value of public choice-based analysis will be revisited. 
developed by the ISWG, replacing it with an un-vetted version that provoked the ire of its members?

IGA may have amended the International Strategy action priorities knowing that no new spending on its implementation was forthcoming, and that it would be better to propose status quo actions that could be continued as opposed to new measures that could not be implemented in the face of departmental pushback. Along this line of argument, IGA may have modified International Strategy draft recommendations to prevent line departments from adopting new policy initiatives (while accepting at face value the argument that those new responsibilities came with no program delivery dollars), only to go back and lobby BOM for unilateral increases after-the-fact to ensure that the department would be able to delivery IGA's International Strategy. Alternatively stated, it is conceivable that IGA re-worded a number of action priorities drafted by the ISWG as a way to ensure that departments would not be able to approach BOM for new money after-the-fact because they so closely represented existing department mandate items for which program delivery budgeting had already been fixed. This would have been breathtakingly Machiavellian.

On the other hand, IGA may have recognized that priorities advanced by the ISWG demonstrated policy stasis, and sought to fine-tune the Strategy to propose solutions and activities to problems that did not exist, or were not yet identified, a move that offended ISWG members. In both scenarios, IGA adopted a course of action designed to maximize 
its position as a central player in corporate policy while tempering expectations of what can be accomplished.

It is here that this study considers the utility of GCM as an explanatory factor to New Brunswick's International Strategy.

\section{The Garbage Can Model}

The basic tenets of GCM as established in Chapter 2 relate to a presence of irrationality in: policy design and implementation; intra and inter-bureaucratic engagement; and resource acquisition required for policy implementation. From a behavioural perspective, it was also established that irrationality could be identified by reliance on habit, conformity, and adoption of culturally-ordained mandates and solutions. As such, policy solutions were seen to pre-empt identification of the problems they purported to solve, thus transforming government into a garbage can or repository into which sundry policy solutions could be deposited and stored until they could be used, or until problems could be developed that matched the solutions in hand. It should be noted that the term "garbage" should not be equated or construed to mean that policies are actually garbage (i.e. useless), but rather that they are "dumped" into government as if it were a repository of unused policy items to be stored for later use. Those dumped items according to Cohen, March and Olsen, however, (the original theorizers of GCM) cannot always be judged to be the product of rational development processes. 
If we apply this paradigmatic model to New Brunswick's International Strategy, the analysis can be modified in several ways.

Solutions Leading Problems

In an ideal and rational process of policy development, New Brunswick's International Strategy would have been developed as a solution to an identified problem. Sequentially, this relationship may look like:

$$
\text { Problem } \rightarrow \text { Solution }
$$

By extension, the inverse or corollary of this relationship may look like:

$$
\text { Solution } \rightarrow \text { Problem }
$$

The Prosperity Plan of 2002 called for the development of the International Strategy, however, no immediate or prospective issues for which the International Strategy would be required were outlined in that strategic document. As if an afterthought, mention of development of an International Strategy came exclusively on a single line on the $40^{\text {th }}$ of 41 pages, requiring its architects to establish the strategy's parameters in response to problems that had yet to be identified.

What were the specific policy domains that this International Strategy should address? If IGA was to develop this International Strategy, what would be its broad objectives? As 
noted earlier, the International Strategy that was ultimately proposed and finalized sought to:

a) Promote intra-governmental collaboration and policy integration;

b) Advance provincial interests on the world stage in specific policy domains; and

c) Optimize intergovernmental relations and strategic collaboration with the Government of Canada in areas of concurrent policy jurisdiction.

Regarding point b), a two-tier game was being played.

On one hand, at the outset of the International Strategy development process officials in IGA began scanning the Provincial government landscape to understand what activities internationally-active departments were engaged in, and how the International Strategy that was expected could support those activities. A circuitous logic to developing the Strategy was applied, wherein problems the International Strategy was being developed to address were not yet known, while IGA at the same time started accumulating solutions that could be articulated in the Strategy, unilaterally as well as within the context of the ISWG.

These solutions, such as the development of an ITA were not in response to pressing problems, but rather seen as predisposed to being quick "hits" with which the International Strategy's (and IGA's) ability act quickly and decisively could be operationalized. Strategic solutions being pre-developed were designed to support 
existing policy priorities that did not deviate from the status quo, or reaffirmed existing policies and practices.

Ironically, even with an inversion of the problem/solution dynamic, the overview of policy sectors in which federal and provincial priorities intersected reveal that the solutions did not solve the problems they sought to address. An anonymous official at Business New Brunswick notes,

The International Strategy was not a tight document. On the trade and investment side, it didn't match the markets we were actually involved in. We ended up matching our markets to those in the International Strategy, not vice-versa. China may have been a focus for IGA, Immigration and Education, but what we supposed to do there? It didn't make sense. Actually it does...there was one person at IGA who was challenging on this market and exerted authority to make it a fait accompli. It was based on an individual, and wasn't supposed to be the intent of the Strategy. ${ }^{560}$

From a macro-perspective, in the absence of a clear mission deriving from the Prosperity Plan, development of New Brunswick's International Strategy sought to affirm its commitment to federalism and its willingness to work in partnership with various stakeholders, and to develop action priorities that would help New Brunswick take advantage of new opportunities afforded by recent globalization.

For example, while the 58 action priorities posited in the International Strategy purport to do precisely this, the overwhelming majority of them represented status quo activities already pursued by line departments and initiatives that were brainstormed in ISWG

$560 \quad$ Anonymous, Interview, April 3, 2009. 
meetings that were solutions to problems that had not been formally identified, including introduction of the Friends of New Brunswick Program ${ }^{561}$ (a suggestion from DFAIT to mirror a similar initiative in Scotland) and the addition of "international diplomacy and competencies as one of the training services offered to companies preparing to export."

The disconnect between the solution of international diplomacy and competency training for businesses preparing to export and the actual need for such policy is telling. As we saw in the chapter dealing with policy issues related to the International Strategy, during its development, approximately $90 \%$ of New Brunswick's exports were bound for US markets, a trend that did not require the type of training the Strategy called for. What was the rationale for its inclusion to the Strategy? Why was it pitched? Who would take responsibility for the cost of the training's design and delivery? Such rhetorical questions do not have definitive answers, yet are important to keep in mind as the International Strategy's various non sequiturs are noted. Furthermore, action priorities concerning augmenting trade and FDI attraction, increasing immigration, and supporting New Brunswick's participation in La Francophonie did not represent a deviation from what the Province had been attempting for the previous few decades.

\section{Demonstrations of Irrational Policy Articulation}

One demonstration of irrational policy articulation in the International Strategy called for an augmentation of the province's participation in international development. In this area,

\begin{tabular}{ll}
\hline 561 & Province of New Brunswick, International Strategy, 2003: 21. \\
562 & Province of New Brunswick, International Strategy, 2003: 22.
\end{tabular} 
deliberations of the ISWG demonstrated a common belief that outside of some projects being pursued by the New Brunswick Community Colleges (NBCC) in the area of costrecovered curriculum training and delivery in some limited markets in the developing world, the Province did not have: appreciable financial resources to commit; formal jurisdiction; past track record of successes; or potential to translate international development opportunities into increased trade, FDI or immigration. Nonetheless, the Province developed and pursued several objectives noted in Chapter 3 on the basis that it wanted to act "in concert with Canada's international development agenda," 563 an action priority whose apparent goal was to align New Brunswick with the federal interest.

While strategic reasons for pursuing international development as an area in which New Brunswick can support Canada's Overseas Development Assistance (ODA) mandate may have been designed to serve interests such as bolstering intergovernmental cooperation in Francophonie Africa, the years following release of the International Strategy only demonstrated a continuation of status quo relationships and partnerships already in place. $^{564}$ In this instance neither gains nor losses were realized as a result of the International Strategy. Rather, they were impact neutral--it mattered not that they existed or not.

In another instance of decision-making that can be examined from a GCM perspective, the International Travel Advisory introduced in Chapter 3 demonstrates how solutions that are pre-conceptualized can be illogically implemented and constitute the source of

563 Province of New Brunswick, International Strategy, 2003: 18.

564 Province of New Brunswick, Progress Report, 2006: 13-14. 
intra-governmental tensions, conflict and friction. Given the significance of this particular initiative to the GCM arguments, this section revisits the ITA from a slightly different perspective (at the risk of seeming somewhat repetitious). The original intent of the ITA was to better coordinate international travel by provincial government officials, as well as to facilitate IGA's ability to gather information on where efforts were being expended. The original idea for what became the ITA was generated during the homework phase of developing the International Strategy, at which time answering the "where is New Brunswick active" question proved difficult.

While the ITA summary reports were originally sent to a wide group of provincial government officials who tend to travel as part of their work-plan, circulation of the ITA was soon limited by IGA to only be sent to Deputy Ministers in response to fears from some officials that their travel to foreign markets would be questioned by those who were jealous or harboured resent over their international trips. In another modification to the original intent of the ITA, IGA was established as the lead agency responsible for the corporate approval of all provincial government international travel (with the exception being the State of Maine), with powers to approve and reject departmentally-sanctioned international travel requests as per existing standard operating procedures as indicated in the Province's travel policy. In this way, the ITA demonstrated operational, administrative and policy-based incongruence with dyadic relationships between: a) BOM and ITA processes; b) Departmental autonomy and IGA "coordination;" and c) financial efficiency and financial inefficiency. 
In discussing the migration of the ITA from information coordination tool to central permission granting body, an anonymous official involved with the Province's economic development interests notes that the transformation had little to do with bona fide operational concerns, but rather, with a fear from the Premier's Office that a public relations gaffe involving two Ministers' travel to France (and claiming the same accomplishments within a short span of time) would be repeated. ${ }^{565}$ In this instance, two Ministers of the Crown traveled to France within a relatively short time frame of one another. Upon returning to New Brunswick each claimed to have accomplished the same objectives, causing the Opposition, media and ordinary New Brunswickers to openly question whether the government had adopted sufficient measures to ensure nonduplication of departmental activities while undertaking expensive international travel. The subsequent political embarrassment prompted the Premier's Office to seek transformation of the ITA from an information gathering tool to a gateway mechanism by which similar embarrassments could be avoided, a move that caused significant internal turmoil among ministries engaged in significant amounts of operations-related international travel.

The International Travel Advisory created a lot of animosity in the public service. IGA told us that they weren't going to use this initiative to decide who travels where, that this wasn't the purpose. In the end, that's what they did. We couldn't make sense of it. ${ }^{566}$

565 See Andrew Philips reporting on IGA Minister Percy Mockler's mission to France, "Province Leading Eight-Day Mission to France," New Brunswick Telegraph Journal, November 1, 2003, followed by Shawn Berry reporting on Tourism and Parks Minister Joan MacAlpine's mission to France and Germany, "Province Will be Promoted at European Tourism Exhibition," New Brunswick Telegraph Journal, December 2, 2003. 566 Anonymous, Interview, Fredericton, March 31, 2009. 
When asked about the same issue, an official in a line department function noted,

I think that IGA can play a necessary role for government. But when it gets in the way of line departments by interfering in the autonomy of Deputies to approve departmental travel, it's a real sore spot. When they switched from collecting and sharing information to approving our travel, it cost government lots of money in flight costs, missed flights and lost opportunities. Didn't really make a lot of sense. I see value in the coordinating role, but whoever decided to get into travel approvals overstepped their boundaries. ${ }^{567}$

Despite the disjuncture between the goal of the ITA as a knowledge-sharing tool and its metamorphosis into an approvals process, the Province reported in January 2006 that "Within government, the Province has introduced an International Travel Advisory intended to facilitate greater cooperation between departments with converging interests in foreign markets." 568

GCM and International Environmental Stewardship Commitments and Reported Progress

The garbage can model of solutions pursuing problems is also seen in the International Strategy Progress Report's discussion of the "International Environmental Stewardship" action priority. Irrational solutions were proposed to problems not yet identified, and when the time came to report on implementation progress of the International Strategy, the progress reported largely relied on status quo activities whose initiation and/or completion date pre-dated the International Strategy's publication in 2003.

568 Province of New Brunswick, Progress Report, 2006: 19. 
By way of background ISWG deliberations did not involve effective representation of officials from the Department of the Environment. To the surprise of several members of the ISWG whose departments have secondary or fiduciary obligations related to the environmental elements (such as administration of the Environmental Impact Assessment (EIA) process and working with international companies involved in "Brownfield" industrial processes), there had been virtually no consultative dialogue on the matter. Nevertheless, the final draft of the International Strategy contained several action priorities precisely on this subject matter, presumably added by IGA, the Premier's Office or other elite group or representative within the senior echelons of the New Brunswick government, which are mentioned in the Chapter 3 iteration of the International Strategy.

Accordingly, the 2006 Progress Report, the following action activities (in plain font) were reported as "progress made to date." Underneath each of the itemized action activities, however, is a critical explanation (italicized) of the progress indicators associate to each, suggesting that in reality little meaningful or actual progress was realized:

a) The Province is a committed member of the NEG/ECP Committee on the Environment and co-chairs its subcommittees on Acid Rain and Mercury, which addresses issues of regional concern and has a strong role in the work of the Gulf of Maine Council on the Marine Environment.

With New Brunswick as a member, the NEG/ECP began deliberations on the Environment in the 1980s. The Acid Rain and Mercury subcommittee was created in $1998 .^{569}$ 
b) The Province is party to the Commission Mixte France/Canada regarding fisheries and Gulf of Saint Lawrence governance relating to Saint Pierre and Miquelon.

The Commission Mixte France/Canada was created under an agreement between the Government of Canada and the Government of France in 1994. There are 8 Canadian government partners along with representatives from each of the 4 Atlantic Canadian provinces. $^{570}$

c) The NBCC/CCNB works with provincial businesses, including those with environmental expertise, to explore global opportunities. Example: In early $2004 \mathrm{NBCC} / \mathrm{CCNB}$ was instrumental in linking a New Brunswick engineering firm with the Cuban government so that Cuban poultry farms would meet international environmental regulations.

Despite several seed potato purchase and sale agreements and tie-ups with Cuba, New Brunswick companies have very little trading relationships with this country. As such, it is difficult to determine whether this progress realized is a sustainable and replicable "win," or if it is one of a very short list of "environmental" wins.

d) As part of its investment attraction efforts, the Province communicates its environmental regulations to international firms considering expanding their operations to New Brunswick, and promotes provincial businesses with expertise in environmental industries. ${ }^{571}$

The New Brunswick Department of Environment coordinates assessments under the Environmental Impact Assessment Regulation that was established in 1987. Economic development officers responsible for attracting inbound investment to the Province have routinely conveyed information about the Province's EIA process to target companies since 1987, without which proposed projects do not receive provincial and/or federal approval to continue with project commencement. $^{572}$

570 See ACOA, News Release, "France-Canada Joint Regional Cooperation Commission Spawns Opportunity for New Brunswick Company," June 27, 2003.

571 Province of New Brunswick, Progress Report on Prospering in a Global Community: New Brunswick's International Strategy, January 2006: 15.

572 See New Brunswick Department of the Environment and Local Government, "Environmental Impact Assessment in New Brunswick," URL: http://www.gnb.ca/0009/0377/0002/0020-e.pdf; Accessed, January 2009. 
Based on these four examples of "progress" related to implementation of the International Strategy, indeed, little real progress was realized. Despite the incidence of this style of misleading performance reporting, the following section will discuss other instances in which intra-governmental stakeholders simply refused to allow the design of policy undertakings for which the realization of implementation success was slim to nonexistent.

Rational Actor Response to Perceived Irrational Demands

While IGA might be criticized for pursuing policy initiatives that did not appear entirely rational to colleagues in line departments, the same irrationality cannot be assigned to the decision-making chains at play in the line departments whose input was sought by IGA in the development of action priorities in the International Strategy.

Early in the International Strategy development process it was suggested to ISWG members that no new funding would be sought or assigned to the International Strategy, and that its implementation would have to come from existing resources from departments under whose mandate the policy imperatives fell. Once publicly-released, the International Strategy would be implemented by government departments voluntarily and proactively taking responsibility for action priorities (referred to by IGA in a number of communiqués to line departments and ISWG members as "self assignment"). 
For those with experience in departmental strategic planning and policy development, the flaw in IGA's logic was immediately obvious- if implementation of the International Strategy came with no new resources, and departments were free to pitch action priorities for the International Strategy without having to base them on existing or clear-andpresent problems, what value would there be to pitching anything but continuation of the status quo? A rational policy determination chain may look something like:

$$
\begin{gathered}
\text { Problem } \rightarrow \text { Solution } \rightarrow \text { Alternatives for Implementation } \rightarrow \text { Action }= \\
\text { Intended Results }
\end{gathered}
$$

In the case of New Brunswick's International Strategy, however, seemingly big changes were attempted, incremental change was hoped for, and analysis of trade and investment and immigration figures for example demonstrate that the anticipated change was simply not realized. That particular policy determination chain might have looked something like:

\section{Solution $\rightarrow$ Create Policy Option to Fit Solution $\rightarrow$ Implement Solution $=$ No Effect or Maintenance of Status Quo}

This disjointed policy determination chain brings the observer to some rather important questions, namely- what are the costs and effects for ineffectual policy choices, what policy oversight mechanisms may be engaged to prevent future repeats, what are some of the factors that prompt government agencies to engage in such administrative practices, and should punitive consequences be considered to avoid the institutionalization of such 
practices? Building on this discussion, the following section goes on to examine the implications of New Brunswick's international policies and practices on Canadian federalism.

\section{Implications Regarding Canadian Federalism}

The following two citations contained in annual reports of DFAIT suggest that the federal government places a great deal of emphasis on inter-jurisdictional policy harmonization, cooperation and partnership, which in turn will positively impact on advancing Canada's writ-large interests in international relations.

Coordination on policy planning will be increased with other federal departments and agencies as well as the provinces and territories. This will ensure greater integration of foreign and domestic policies, fuller engagement of the provinces and territories in foreign policy, and consistency of federal laws and regulations with Canada's international obligations. ${ }^{573}$

In enhancing its partnerships with the provinces and territories, the Department will provide support for greater integration of federal, provincial and territorial policies related to international affairs. This process will help reinforce a climate of trust and dependency. It will also better enable other levels of government to play a role in fostering Canadian interests internationally $[\ldots]^{574}$

573 Department of Foreign Affairs and International Trade, Estimates, Part III, Report on Plans and Priorities, Ottawa: Canadian Government Publishing, 2003: 19.

574 Department of Foreign Affairs and International Trade, Estimates, Part III, Report on Plans and Priorities, Ottawa: Canadian Government Publishing, 2003: 54. 
The central message relating to Canada's federal system and this dissertation is relatively simple-Canada's system of federalism has not evolved sufficiently in the face of recent globalization to provide clear parameters regarding central and regional government relations. While lack of intergovernmental and inter-jurisdictional clarity is a normal feature of most federal systems, it provides new challenges as they relate to paradiplomatic activities. While, as demonstrated by the two passages above, DFAIT is willing to start working with the provincial governments on a more proactive and substantive basis, they are only statements of principle if unaccompanied by real action. The inter-jurisdictional challenges, tensions and opportunities for collaboration are macrocosmic of those within the nation-state though, and as in those domestic situations and circumstances, the conduct of collaborative intergovernmental relations helps both orders of government serve the interests of the populations they serve.

The International Strategy continually stresses New Brunswick's desire to engage in cooperative rather than competitive federalism in its relations with the Government of Canada, and this principle is demonstrated in the Province's pursuit of interest in the three policy areas discussed in Chapter 4. This cooperation, it has been argued, leverages the International Strategy's symbolic value to promote cooperation through promoting increased linkages between political and (but mostly) bureaucratic executives. While it occasionally veers towards competitive federalism and advancement of provincebuilding/ competitive federalism, New Brunswick's pursuit of international priorities is rarely conducted farther than arm's length from the federal government. 
In the case of the Province's interests in La Francophonie, the confluence of its own Francophone composition and the federal government's desire to contain the Province of Québec's strident international modus operandi resulted in the Canada-New Brunswick Francophonie Agreement that is the financial basis for the Province's activities in the French-speaking world. That said, despite the Province's efforts to align its interests along the federal government's BRIC strategy, or in strategic sectors of interest to the federal government, it is also true that New Brunswick has not been the beneficiary of any special "one-off" deals that do not directly serve the federal government's own interests. Although the asymmetric consideration that New Brunswick has received has resulted in positive gains for the province, and have increased its comfort level in exploring opportunities in global markets, the following paragraphs outline several difficulties New Brunswick has had in working with the Government of Canada abroad.

In international markets, DFAIT officials frequently tell provincial representatives (as they do in F/P/T - public tables such as the Focus India Plenary) that they should not "go it alone," and that without leveraging the Canada brand, they will not receive the same level of success as if they work collaboratively with their federal colleagues. Implicit in this is a warning undercurrent that provinces that seek international opportunities through active exclusion of the federal government will find federal officials less likely to assist in areas of concurrent or federal jurisdiction. In other words, "play with us nicely now so we play nicely with you later." As provinces continue to engage in province-building in their areas of competence and realize greater levels of success on the world state, the federal government will increasingly lose its influential grip over the provinces. 
Despite 1ts failings, one of the positive aftermaths of the International Strategy was that $1 \mathrm{t}$ placed a premium on line departments more proactıvely engaging DFAIT officials posted abroad while on international travel, as well as closer relations between DFAIT officials at Pearson and IGA officials That said, the ITA's farlure to provide IGA with strategic intelligence on the international activities of other departments represents a missed opportunity to engage DFATT officials in foreign markets in a cooperative fashion, a tendency that seems natural for New Brunsw1ck In this light, it is helpful to note that in the title of his doctoral dissertation David Dyment referred to Ontario as the "reluctant traveler," ${ }^{, 575}$ whose international forays ebbed and flowed as opportunities presented themselves Given New Brunswick's reliance on the federal government for strategic intelligence and partnershıp, cooperation, financial programmıng and goodwill, perhaps New Brunswick can be called the "friendly hitchhiker"

Intensifying globalization, increased transnationalism and proliferation of constituent orders of government on the internatıonal stage may be used as a rationale supportıng a new foreign policy calculus that values the efficacy of the state and regional government inputs Through examination of New Brunsw1ck's 1nternational relations, policies and practices, it has been argued that federal-provincial and inter-provincial asymmetry supports a strong and contınued role for the central government in international relations, both as a measure of assisting those provinces whose asymmetry is defined by their diminished capacity for autonomous action, as well as on account of their self-serving

575 David Dyment, The Reluctant Traveller Understanding the International Actlvities of a Non-protodiplomatic Component Government The Case of the Ontario Government from 1945 to 1995, Ph D Dissertation, Un1versité de Montréal, April 1996 
desire to mitigate the seemingly insatiable efforts of other larger provinces to take an active and direct role in the international economy.

Canada's flexible and highly decentralized federal tendencies borne of its geographic expansiveness, linguistic fragmentation, social heterogeneity and fluid political culture have contributed to confusion regarding a formal and institutionalized understanding of who does what on the world stage. James, Michaud and O'Reilly note, "Canada, which lacks clear constitutional guidelines to orient its foreign policy, must reconcile its obligations as a sovereign state with its recognized responsibilities to its provinces, which implement international treaties within their spheres of jurisdiction.. ${ }^{.576}$ Given the considerable degree of asymmetry between the provinces and their relationship with the federal government, it can be argued that greater clarity may be sought by examining what is done in other jurisdictions. Michelmann for example argues ${ }^{577}$ that Canada might look at best practices in federal (but more centralized) jurisdictions such as Germany to see how regional (Länder) governments are formally included into the Central Government's negotiation of international agreements and treaties. Moreover, examining constitution-altering mechanisms such as how the composition of the Federal German upper house allows for greater regional government interest representation and articulation than the Canadian Senate may shed light into how representation of New Brunswick's (and the provinces') paradiplomatic interests has been disastrous.

576 Patrick James, Nelson Michaud, Marc J. O'Reilly, "Conclusion: Understanding Canada's Foreign Policy Challenges," in James, Michaud, O'Reilly, (eds.), Handbook of Canadian Foreign Policy, 2006: 515.

577 See Hans J. Michelmann, "The Federal Republic of Germany," in Michelmann, Soldatos, (eds.), Federalism and International Relations, 1990: 211-244. 
On this point, based on the research conducted, both in policy areas where collaborative $\mathrm{F} / \mathrm{P} / \mathrm{T}$ relations were evident and in areas where the relationship was more strained (if not completely fragmented), the lack of integration between federal diplomatic and commercial activities and provincial paradiplomatic activities is encouraged and perpetuated by disjointed intergovernmental structures. In this dichotomous sense, while Canada's decentralized federal system does not feature the restrictive features of other more unitary or centralized federal systems such as the U.K., Australia or the U.S., ${ }^{578}$ which limit the extent to which constituent orders of government may participate in paradiplomatic activities, the Canadian system must deal with a structural de-linkage between the federal and provincial governments.

This lack of integration, however, may be mitigated through federal and provincial recognition of the distinction Dupré ${ }^{579}$ makes between summitry-based intergovernmentalism and functional relationships as expressed through collaborative federalism, the latter of which suggests a greater emphasis on co-determination of international policies. Moreover, as was the case as Canada emerged from the post-war period, the need for intergovernmental tempering of jurisdictional clash would be influenced by the confluence of provincial jurisdiction and federal spending and policymaking powers.

578 Earl Fry notes, "the U.S. Constitution clearly stipulates that foreign policy is controlled by the U.S. Congress [...] Undoubtedly, growing interdependence will provoke periodic clashes among the different levels of government." in The Expanding Role of State and Local Governments in U.S. Foreign Affairs, 1998: 99-100.

579 See J. Stefan Dupré, "Reflections on the Workability of Executive Federalism," in Richard Simeon (ed.), Intergovernmental Relations, Toronto: University of Toronto Press, 1985, 1-32, and Richard Simeon, Ian Robinson, State, Society and the Development of Canadian Federalism, Toronto: University of Toronto Press, 1990. 
While there are various bilateral and multilateral mechanisms through which issues of interest and concern can be articulated, it is also true that centrifugal forces in Canadian federalism empower and encourage new levels of extra-territorial province-building that the federal government must come to grips with. And neither the 1867 BNA Act and 1982 Constitution Act provide any formal and structural mechanisms through which provincial paradiplomatic interests could be advanced.

The time has come to address that deficiency.

\section{Issues for Future Consideration}

As we come to terms with the past several years of New Brunswick's international affairs, questions come to mind on what the future has in store. If we were to forecast what issues for future consideration are most important and relevant to New Brunswick and its international interests, what would they be? Following is an admittedly mechanically-presented list of issues that may form the basis of future work concerning small provinces and their paradiplomatic activities.

1. Issues regarding conflicting and concurrent jurisdiction may require Canadian legislators to look to new forms of multi-level governance, which have been embraced in Europe as a means to deal with increasingly direct regional government involvement in international affairs. Given Canadian provinces' international interests and their integration to the North American market through NAFTA, 
regional associations such as the $\mathrm{NEG} / \mathrm{ECP}$ and simple regional proximity, how might the emerging field of multi-level governance (and its emphasis on the integration of "sub-national," national and supranational orders of governance) further inform our examination of New Brunswick's paradiplomatic activities?

2. Robert Putnam noted that "[...] we need to move beyond the mere observation that domestic factors influence international affairs and vice versa, and beyond simple catalogs of instances of such influence, to seek theories that integrate both spheres, accounting for the areas of entanglement between the two." 580 Canadian scholars such as Christopher Kukucha have attempted to design research that establishes theoretical parameters in which the paradiplomatic activities of provinces (especially in the area of trade and commerce) can be examined. This remains a worthwhile agenda, and as the viability of province-building is reestablished, should be revisited.

3. In an age of intensified globalization, should the Maritime provinces consider informal and formal union as a mechanism to increase their own size and ability to compete on the world stage? Are regional economic development projects such as the Atlantic Gateway and the unifying concepts such as Atlantica viable and worth exploring, and what are the political issues that support and problematize leveraging more formalized mechanisms of regional cooperation?

580 Robert Putnam, "Diplomacy and Domestic Politics: The Logic of Two-Level Games, International Organization, 42(3), 1988: 433. 
4. How might Canada's federal system be re-balanced to account for the increasingly international forays of the provinces? Are there ways to rebalance the system to account for paradiplomacy within the existing parameters of Canadian federalism, or are Constitutionally-altering mechanisms required to make substantive changes to the system? And, not to discount other dynamic factors, what consideration should be given to the political ramifications of the federal government ceding and facilitating greater paradiplomatic powers to the provinces?

\section{Final Remarks}

This last section provides a few pointed policy recommendations and final remarks.

\section{Policy Recommendations}

Based on the research conducted in this dissertation, the following policy recommendations might be considered by the New Brunswick government.

1. In 2003 the Council of the Federation (COF) was created to foster greater collaboration in inter-provincial relations and $\mathrm{F} / \mathrm{P} / \mathrm{T}$ relations. Given the importance of a vibrant international policy to New Brunswick, and Canada, the Province should exhort the COF to establish a standing committee to deal with F/P/T Relations in International Relations. ${ }^{581}$

581 See Nossal, The Politics of Canadian Foreign Policy, 1989: 265. 
2. Pressure DFAIT to restart the F/P/T Focus India Plenary, corresponding China Committee, and institute quarterly meetings between the CFP division of DFAIT and the Intergovernmental Affairs units of Canadian provinces to discuss foreign policy conduct.

3. Explore options to take advantage of hitherto untapped $\mathrm{F} / \mathrm{P} / \mathrm{T}$ partnership opportunities, such as: co-location and staff interchange programs.

4. Break down IGA's insular and protected pursuit of activities undertaken within the Francophonie envelope in favour of defining and redefining new ways to leverage the Canada-New Brunswick Agreement for commercial, trade and investment promotion activities.

5. Redraft the 2003 International Strategy to account for lessons learned in its implementation and the 2006 Progress Report with a front-end commitment to seek funds for its implementation from BOM after successfully passing through the P\&P Committee of Cabinet.

6. Reinstitute the ISWG and ITA with measures in place to prevent power grabbing by IGA and facilitate maximum corporate benefit.

7. Arrange adequate human and financial resources with which to support line departments' implementation of action priorities that may require their 
cooperation through successful passage through the P\&P and BOM Committees of Cabinet.

8. Take seriously the process requirement for meaningful corporate consultation and engagement, and implement measures to repudiate elite accommodation and personalization of policy development and articulation.

9. In the absence of new funding, ensure strategic inclusion of departmental interests that represent a strategic blend of existing and new activities that represent solutions to existing and/or identified problems and issues.

10. While the Province's pursuit of international opportunities places the government of the day in a vulnerable position to face criticism by the Opposition as well as the province's general public, highly concentrated media and civil society should resist the urge to view paradiplomatic activities undertaken by the executive and legislative branches of government as a target for attack for political points, especially when seat margins in the Legislature are narrow.

11. Institute regular and ongoing gatherings with the objectives originally advanced by the International Business Symposium as a measure of federal-provincial collaboration. 


\section{Conclusion}

As New Brunswick faces a new and uncertain world full of opportunities, it is clear that regional governments will play a larger and enhanced role on the world stage. That international arena is far different than the one known by John A. MacDonald, in which a highly centralized strain of federalism and foreign relations was viewed as a hedge against foreign dangers. In this new world provinces can adopt their own measures of self help, including through the adoption of international strategies, strategic policy-making and direct involvement in areas in which they enjoy constitutional jurisdiction. Reliance on the federal government for protection of regional interests is waning; institutions whose original intent was to safeguard regional interests, most notably the Senate of Canada have been criticized for their ineffectiveness for straying from the role originally envisaged by Canada's founding fathers.

Although this dissertation has cast (unexpectedly) critical views and perspectives on New Brunswick's international policies, we should not be quick to chalk up the Province's International Strategy initiative as a failure. While problems associated with the New Brunswick International Strategy are wide-ranging and span consideration of design, implementation and evaluation perspectives, and display characteristics of the garbage can model's inversion of the problem identification-solutions generation relationship, the Province's decision to develop a formal International Strategy was a positive move. 
Vengroff and Rich point out that "New Brunswick might be relatively small in terms of population, but in recent years its government has become increasingly aware of and committed to an active international presence as a core part of its economic development strategy." 582 Notwithstanding various policy, organizational and process-oriented problems New Brunswick caused while developing those international policies mentioned by Vengroff and Rich, it serves us well to recall these problems were caused by a small jurisdiction prepared to make mistakes and take risks in pursuing its fortunes on the world stage.

In this sense, application of GCM as an analytical concept suggests that the Province of New Brunswick developed solutions to international problems not yet identified as a way to subsequently define problems for which the solutions were already in hand. Whether this was in deference to uniquely political objectives sought in the international arena, or to proactively limit the Province's exposure to committing itself to an aggressive international policy it could neither afford nor have a reasonable chance of successfully implementing, the opportunity for the Province to learn from this experience has been lost given routine bureaucratic "churn," change in government and shifting policy goals that deemphasize the need for an "international policy."

Fragmentation of federal-provincial efforts on the international stage offers little hope for the future. The ebb and flow between central governments' cyclical efforts to centralize and decentralize international policies with intergovernmental implications result in incoherence and missed opportunities in areas examined such as trade, investment and 582 Vengroff and Rich, "Foreign Policy By Other Means," 2006: 120. 
1mmigration promotion. Instead, a new commitment to co-operative federalism in this era of globalization will go a long way to reinforce collaboration and interdependence. The ability to engage such interdependency is seen in the way that federal and provincial institutions work together within La Francophonie. The question for the future is whether such cooperation can be replicated in othe1 policy areas of joint interest. When dealing in new policy frontiers, however, especially in paradiplomatic affairs that may push New Brunswick outside its comfort zone of quiet acquiescence of the Government of Canada's objectives, the Province's willingness to experıment, push and err will be paramount. 


\section{BIBLIOGRAPHY}

\section{Published Works}

$44^{\text {th }}$ Annual Premier's Conference (APC), "Premiers Announce Plan to Build a New Era of Constructive and Cooperative Federalism," (press release), July 10, 2003.

$44^{\text {th }}$ Annual Premier's Conference (APC), "Canada-United States Relations," (press release), July 11, 2003.

ACOA, News Release, "15 Community Economic Development Agencies in New Brunswick Unveil as Enterprise Network," July 18, 2002.

ACOA, News Release, "France-Canada Joint Regional Cooperation Commission Spawns Opportunity for New Brunswick Company," June 27, 2003.

ACOA News Release, "Minister Mackay to Lead Canada's Atlantic Gateway Business Mission to India," Fredericton, New Brunswick February 14, 2008

ACOA News Release citing 2004 KPMG Competitive Alternatives Study, "Canada Most Cost-Competitive of G-7 Countries- Three Atlantic Canadian Cities Rank in Top Five Internationally," February 20, 2004. URL: http://mediaroom.acoaapeca.gc.ca/e/media/press/press.shtml?2774, Accessed: June 17, 2007.

Agranoff, Robert, (ed.), Accommodating Diversity: Asymmetry in Federal States, BadenBaden: Nomos Verlagsgesellschaft, 1999.

Aguirre, Iñaki, "Making Sense of Paradiplomacy? An Intertextual Enquiry about a Concept in Search of a Definition," in Francisco Aldecoa, Michael Keating, (eds.), Paradiplomacy in Action: The Foreign Relations of Subnational Governments, USA: Routledge, 1999

Alberta Department of International and Intergovernmental Relations, URL: http://www.international.alberta.ca, Accessed: September 2008. 
Albertoni, Ettore, Mosca and the Theory of Elitism, Oxford: Blackwell, 1987.

Atlantic Institute of Market Studies (AIMS) affiliated website for the Atlantica project, URL: http://www.atlantica.org, Accessed: September 2008.

Atlantic Institute for Market Studies, Brian Lee Crowley, "Equalization's Good Intentions are Not Enough," Citing Public Accounts 2001, Volume 1, Table 3.8, URL: http://www.aims.ca/equalization, Accessed: February 13, 2007.

Allard, Réal; Landry, Rodridgue, "French in New Brunswick," in John R. Edwards, (ed.), Language in Canada, Cambridge: Cambridge University Press, 1998

Allison, Graham, Essence of Decision, Boston: Little, Brown Publishing, 1971.

Allison, Graham, Halperin, Morton, "Bureaucratic Politics: a Paradigm and Some Policy Implications," in Tanter, Raymond; and Ullman, Richard H., (eds.), Theory and Policy in International Relations, Princeton: Princeton University Press, (DATE?).

Atkey, Ronald G., "The Role of the Provinces in International Affairs," International Journal, Winter, 1970.

, "Provincial Transnational Activity: An Approach to a Current Issue in Canadian Federalism," Ontario Advisory Committee on Confederation: Background Papers and Reports, Volume 2, Toronto: Queen's Printer, 1970.

Atlantic Provinces Economic Council (APEC), Report Card: Nominee Programs Boost Atlantic Immigration, July 2008.

Baier, Gerald, Courts and Federalism: Judicial Doctrine in the United States, Australia and Canada, Vancouver: UBC, 2006

Baier, Gernald, The Courts, the Division of Powers, and Dispute Resolution, in Bakvis and Skogstad, (eds.), 2008. 
Banting, Keith G., "The Three Federalisms: Social Policy and Intergovernmental Decision-Making," in Herman Bakvis, Grace Skogstad, (eds.), Canadian Federalism: Performance, Effectiveness, and Legitimacy, $2^{\text {nd }}$ Edition, Toronto, Oxford University Press, 2008

Bakvis, Herman; Skogstad, Grace, (eds.), Canadian Federalism in the New Millennium, Toronto: Oxford University Press, 2002.

Bakvis, Herman, "Canadian Federalism: Performance, Effectiveness, and Legitimacy," in Bakvis, Skogstad, (eds.), Canadian Federalism: Performance, Effectiveness, and Legitimacy, Don Mills: Oxford University Press, 2002

Balthazar, Louis, "Québec's International Relations: A Response to Needs and Necessities," in Brian Hocking, (ed.), Foreign Relations and Federal States London: Leicester University Press, 1993.

Balthazar, Louis, "The Quebec Experience: Success of Failure," in Francisco Aldecoa, Michael Keating (eds.), Paradiplomacy in Action, London: Frank Cass; and Luc Bernier, "De Paris à Washington: La politique internationale du Québec, Montreal: UQAM Press, 1996.

Balthazar, Louis; Bélanger, Louis; Mace, Gordon, Trente Ans de Politique Extérieur du Québec, 1960-1990, Québec : Centre québécois de relations internationales/ Les éditions du Septentrion, 1993.

Barber, Benjamin J., Jihad vs. McWorld: How Globalism and Tribalism are Reshaping the World, New York: Ballentine Books, 1996

Baumgartner, Frank; Jones, Bryan D., Agendas and Instability in American Politics, Chicago: University of Chicago Press, 1993.

Beck, J.M., (ed.), The Shaping of Canadian Federalism: Central Authority or Provincial Right?, Toronto: The Copp Clark Publishing Company, 1971.

Bellamy, David J., "The Atlantic Provinces," in David J. Bellamy, Jon H. Pammett, Donald Cameron Rowat, (eds.), The Provincial Political Systems: Comparative Essays, Cambridge University Press, 1976. 
Bellamy, Richard P., Modern Italian Social Theory: Ideology and Politics from Pareto to the Present, Cambridge: Polity, 1987.

Bélanger, Claude, "Cooperative Federalism," Studies on the Canadian Constitution and Canadian Federalism, Marianopolis College, 2001.

Bendor, Jonathan; Moe, Terry M.; Shotts, Kenneth W., "Recycling the Garbage Can: An Assessment of the Research Program," The American Political Science Review, Vol. 95, No. 1, March 2001.

Bernier, Ivan, International Legal Aspects of Federalism, London: Longmans, 1973.

Berry, Shawn, "Province Will be Promoted at European Tourism Exhibition," New Brunswick Telegraph Journal, December 2, 2003.

Blanchette, Arthur E., "Vive le Québec Libre," Discours de Charles de Gaulle, July 24, 1967, Montréal City Hall, Canadian Foreign Policy, 1945-2000 : Major Documents and Speeches, Durndurn Press Ltd., 2000.

Black, Edwin R.; Cairns, Alan C., "A Different Perspective on Canadian Federalism," Canadian Public Administration, 9, 1966.

Bird, Richard M.; Vaillancourt, François; "Changing with the Times: Success, Failure and Inertia in Canadian Federal Arrangements, 1945-2002," in T.N. Srinivasan, Jessica Seddon Wallack, (eds.), Federalism and Economic Reform, USA: Cambridge University Press, 2006.

Blanchette, Arthur, "The Provinces and Foreign Policy," Canadian Foreign Policy, 1977 1992, Montreal: McGill-Queen's Press, 1994

Bosher, J.F., The Gaullist Attack on Canada, 1967-1997, Montreal, McGill-Queen's Press, 2000.

Bottomley, Samuel A., "Locked and Loaded: Gun Control Policy in Canada," Chapter 1 in Robert M. Campbell, Leslie A. Pal, Michael Howlett, (eds.), The Real Worlds of 
Canadian Politics: Cases in Process and Policy, 4th Ed., Peterborough: Broadview Press, 2004.

Bourque, Benoit, La Participation du Nouveau-Brunswick dans la naissance et le développment de la Francophonie, Travail présenté à Monsieur Michel Tétu, director d'essai et professeur à la faculté des Lettres, Maîtrise en relations internationales, Université Laval, 4 novembre 2000.

British North America Act, 1867, Article 132.

Brooks, Stephen; Miljan, Lydia, Public Policy in Canada: An Introduction, $4^{\text {th }}$ edition, Ontario: Oxford University Press, 2003.

Brossard, J. ; Patry, A. ; Weiner, E., Les pouvoir éxteriurs de Québec, Montreal: Les Presses de l'Université de Montreal, 1967.

Brown, Douglas M., "Provinces Have a Role in Canadian Foreign Policy," Federation: What's New in Federalism World-wide, 2002a.

Brown, Douglas M., "Aspects of Multilevel Governance in Australia and Canada," Globalization, Multilevel Governance and Democracy: Continental, Comparative and Global Perspectives, (Conference paper), Kingston: Queen's University, May 2002b.

Brown, Douglas M., "A Baseline Study of International Relations and the Federal System," (revised draft), Kingston: Institute of Intergovernmental Affairs, Queen's University, December 1999.

Brown, Douglas M., "The Evolving Role of the Province in Canada-US Trade Relations," in Douglas Brown, Earl Fry, (eds.), States and Provinces in the International Economy, Institute of Intergovernmental Relations, Queen's University, 1993.

Brown, Douglas M.; Earl H. Fry, (eds.), States and Provinces in the International Economy, California: Institute of Governmental Studies, 1993.

Brown, Douglas M.; Fry, Earl H.; Groen, James; "States and Provinces in the International Economy Project," in Douglas M. Brown, Early H. Fry, (eds.), States and 
Provinces in the International Economy, California, Institute of Governmental Studies, 1993.

Brown, Douglas M.; Groen, James, Review of Michelmann and Soldatos, Federalism and International Relations, 1990, in Publius, Vol. 24, No. 2, Spring 1994.

Brown, Douglas M.; Murray G. Smith, (eds.), Canadian Federalism: Meeting Global Economic Challenges?, Institute of Intergovernmental Relations, Queen's University, 1991.

Brown, Seyom, "The World Polity and the Nation-State System: An Updated Analysis," International Journal, Summer 1984. (527)

Bull, Hedley, The Anarchic Society, London: MacMillan, 1977.

Burgess, Michael; Gagnon, Alain, (eds.), Comparative Federalism and Federation: Competing Traditions and Future Directions, Toronto: University of Toronto Press, 1993.

Burton, John "World Society and Human Needs," in International Relations: A Handbook of Current Theory, Margot Light; A.J.R. Groom (eds.), London: Pinter, 1985.

Business New Brunswick, "International Trade," URL: http://www.gnb.ca/0398/trade/internat-e.asp, Accessed: October 7, 2003.

Business New Brunswick, News Release, "Province Signs Agreement for St. AnneNackawic Mill," August 3, 2005.

Byrd, Craig; Généreux, Pierre, "The Performance of Interprovincial and International Exports by Province and Territory Since 1992," Input-Output Division, Ottawa: Statistics Canada, 2004.

Cairns, Alan C., "The Judicial Committee and its Critics," Canadian Journal of Political Science, IV(3), 1971. 
Cairns, Alan C.; "Constitution-Making, Government Self-Interest, and the Problem of Legitimacy," in Allan Kornberg, Harold D. Clarke, (eds.), Political Support in Canada: The Crisis Years: Essays in Honor of Richard A. Preston, USA: Duke University Press, 1983.

Cairns, Alan C., "The Governments and Societies of Canadian Federalism," Canadian Journal of Political Science, Vol. 10, No. 4, December 1977.

Cairns, Edwin R., "The Governments and Societies of Canadian Federalism," Canadian Journal of Political Science, 10, December 1977

Cameron, David R., "Canada," in Griffiths, Nerenburg, (eds.), Handbook of Federal Countries, 2002, 2003

Cameron, David, "Intergovernmental Relations in Canada," Forum of Federations, date?

Cameron, David; Simeon, Richard, "Multilevel Governance and Democratic PolicyMaking," Paper delivered to Israel Association of Canadian Studies, 1998.

Canadian Broadcasting Corporation's New Brunswick outlet, http://nb.cbc.ca/features/perfectstrangers Accessed: April 30, 2004.

Canadian Broadcasting Corporation's News (New Brunswick), "2 2 nd Lawsuit Brought Against Immigration Consultant," http://www.cbc.ca/canada/new-brunswick; Accessed: September 2007.

Canadian Centre for Management Development, Moving from the Heroic to the Everyday: Lessons Learned from Leading Horizontal Projects, Ottawa: 2001.

Canadian Institute of International Affairs (CIIA), "Culture and Canadian Foreign Policy," Report of the CIIA Foreign Policy Conference, November 2000.

Canadian International Development Agency (CDA), "CIDA and La Francophonie," URL: $\quad$ http://www.acdi-cida.gc.ca/CIDAWEB/acdicida.nsf/En/JUD-1211134328-PY8, Accessed: January 11, 2009. 
Canadian Study of Parliament Group, "The Future of Canadian Federalism," Ottawa, November 9-10, 1990.

Carr, E.H., The Twenty Years' Crisis, 1919-1939, London: MacMillan, 1946

Centre for Research and Information on Canada (CRIC), "Canadians Say Kyoto Won't Hurt Jobs, But Most Say Ratify Only After Provinces Onside," Press Release, Ottawa, November 5, 2002.

Chandler, William; Bakvis, Herman, "Federalism and the Strong-State/Weak State Conundrum," Publius:The Journal of Federalism, 19(1), 1989.

Citizenship and Immigration Canada (CIC), Facts and Figures 2002: Immigration Overview, 2002.

Citizenship and Immigration Canada, Annual Report to Parliament on Immigration 2002; 2004.

Clarkson, Stephen, (ed.), An Independent Foreign Policy for Canada?, Toronto, The Canadian Publishers, 1968.

Clemons, Randy S.; McBeth, Mark K. McBeth, Public Policy Praxis: A Case Approach for Understanding Policy and Analysis, $2^{\text {nd }}$ Ed., New York: Pearson Education, 2009.

Clokie, H.M., "Judicial Review, Federalism, and the Canadian Constitution," Canadian Journal of Economics and Political Science, Vol. 8, No. 4, November 1942.

Conference Board of Canada, The Employment Effects of Foreign Direct Investment in Atlantic Canada, February 2008.

Conference on the Provinces and Foreign Policy of the CIIA, Edmonton, March 30, 1985. 
Cohen, Andrew, "Too Many Cooks? Provinces Promoting Their Interests Around the World are Challenging Ottawa's Monopoly on Foreign Policy. Think of the Confusion They're Causing Abroad," Saturday Night, September 1989.

Cohen, Maxwell; Molot, Maureen Appel, (eds.), Democracy and Foreign Policy: Canada Among Nations 1995, Ottawa: Carleton University Press, 1995.

Cohen, Michael D.; March, James G.; Olsen, Johan P., "A Garbage Can Model of Organizational Choice," Administrative Science Quarterly, Vol. 17, No. 1, 1972.

Cole, Richard L.; Kincaid, John; Parkin, Andrew, "Public Opinion on Federalism in the United States and Canada in 2002: The Aftermath of Terrorism," Publius, Vol. 32, No. 4, The State of American Federalism, Oxford University Press, 2001-2002, Autumn 2002.

Communications New Brunswick, "Transportation Minister in India to Promote Atlantic Gateway," February 15, 2008

Communications New Brunswick, News Release, "Government Releases New Prosperity Plan for New Brunswick," February 5, 2002

Compact Oxford English Dictionary, URL: http://www.askoxford.com; Accessed: January 2009.

Conference Board of Canada, How Can Canada Prosper in Tomorrow's World: Performance and Potential 2004-05, Canada, 2004.

Conference on the Provinces and Foreign Policy of the Canadian Institute of International Affairs (CIIA), Edmonton, March 30, 1985.

Connolly, William E. Connolly; Chambers, Samuel Allen; Carver, Terrell, (eds.), Democracy, Pluralism and Political Theory, Routledge, 2008.

Cook, Ramsay, Provincial Autonomy, Minority Rights and the Compact Theory, 18671921, Ottawa: Queen's Printer, 1969. 
Cooper, Andrew, (ed.), Canadian Culture: International Dimensions, Toronto: Canadian Institute of International Affairs, 1985

Cooper, Andrew; Higgott, R.A.; Nossal, K.R., (eds.) Relocating Middle Powers: Australia and Canada in a Changing World, Melbourne: Melbourne University Press, 1993.

Courchene, Thomas, "ACCESS: A Convention on the Canadian Economic Systems," Toronto: Ministry of Intergovernmental Affairs, 1996.

Courchene, Thomas, "Celebrating Flexibility: An Interpretive Essay on the Evolution of Canadian Federalism," C.D. Howe Institute, Benefactors Lecture, Montreal, October 16, 1995a.

Courchene, Thomas, "Glocalization: The Regional/International Interface," Canadian Journal of Regional Science, 18:1, Spring 1995b.

Court of Queen's Bench of New Brunswick, Trial Division, Judicial District of Saint John, Case No. S/M/92/2007.

Cox, Robert W.; Sinclair, Timothy J., Approaches to World Order, USA: Cambridge University Press, 1999.

Creighton, Donald Grant; Waite, P.B., John A. Macdonald: The Young Politician, the Old Chieftain, Toronto: University of Toronto Press, 1998.

Cyert, Richard; March, James, A Behavioural Theory of the Firm, Prentice-Hall, New Jersey, 1963

Davidson, E. Jane, Evaluation Methodology Basics: The Nuts and Bolts of Sound Evaluation, Sage, 2004.

Davies, Carl, "There'll Be No High-Priced, Wrap-up Dinner This Time," New Brunswick Telegraph-Journal, November 5, 2003. 
Dehousse, Renaud, "Fédéralisme, asymétrie et interdépendance : Aux origines de l'action internationale de composants de l'Etat fédéral, Études internationales, Vol. XX, No. 2, June 1989.

Department of Education, Province of New Brunswick, News Release, "New Brunswick High School Courses to be Taught to Students in India," February 7, 2006.

Department of Finance, Canada, URL: http://www.fin.gc.ca/fedprov/eqpe.html, Accessed: February 13, 2007.

Destrempes, Hélène; Ruggeri, Joe, (eds.), Rendez-Vous Immigration 2004: Immigration in New Brunswick, Issues and Challenges, (Proceedings of a Conference held in St. Andrew's, New Brunswick, August 2004), Policy Studies Centre/ Atlantic Metropolis Centre, Canada, December 2005.

DFAIT, A Dialogue on Foreign Policy, Ottawa, January 22, 2003.

DFAIT, A Dialogue on Foreign Policy: Report to Canadians, Ottawa, May 1, 2003.

DFAIT, Canada and the World, Ottawa, 1995.

DFAIT, "Canada's Goals in La Francophonie," URL: http://www.international.gc.ca/franco/index.aspx, Accessed : November 12, 2008.

DFAIT, Estimates, Part III, Report on Plans and Priorities, Ottawa: Canadian Government Publishing, 2001.

DFAIT, Estimates, Part III, Report on Plans and Priorities, Ottawa: Canadian Government Publishing, 2002.

DFAIT, News Release, "Canada and New Brunswick Discuss Enhanced International Cooperation," March 9, 2004.

DFAIT, Press Release, "Graham Reports on Foreign Policy Advice from Canadian Public," Ottawa, June 27, 2003. 
DFAIT, Letter to Deputy Minister of Intergovernmental and International Relations (PNB) from Deputy Ministers of International Trade and Foreign Affairs, (acquired through written request to IGA), September 30, 2003.

DFAIT, Estimates, Part III, Report on Plans and Priorities, Ottawa: Canadian Government Publishing, $2003 \mathrm{~b}$.

Diehl, Paul F., (ed.), The Politics of Global Goverance : International Organizations in an Interdependent World, Boulder: Lynne Rienner Publishers, 2001.

Dion, Stéphane, "Collaborative Federalism in an Era of Globalization," Notes for an Address to the Institute of Public Administration of Canada, Government of CanadaPrivy Council Office, Ottawa, Ontario, April 22, 1999.

Doerr, Audrey, "The Role of Coloured Papers: Information, Debate or Advocacy?," Canadian Public Administration, Vol. 25, Fall 1982.

Doerr, Audrey, "The Role of White Papers," in Andrey Doerr and Peter Aucoin, (eds.), The Structures of Policy Making in Canada, Toronto: MacMillan, 1971.

Dror, Yehezkel, "Muddling Through- 'Science' or Inertia?," Public Administration Review, Vol. 24, No. 3, September 1964.

Drucker, Peter, “The Changed World Economy," Foreign Affairs, Spring 1986.

Duchacek, Ivo, The Territorial Dimension of Politics, Within, Among, and Across Nations, Boulder: Westview Press, 1986.

Duchacek, Ivo, "Perforated Sovereignties: Towards a Typology of New Actors in International Relations," in Hans J. Michelmann, Panayotis Soldatos, (eds.), Federalism and International Relations: The Role of Subnational Units, USA, Oxford University Press, 1990.

Duchacek, Ivo; Latouche Daniel; Stevenson, Garth, (eds.), Perforated Sovereignties and International Relations: Trans-Sovereign Contacts of Sub-national Governments, New York: Greenwood Press, 1988. 
Dyck, Rand, Canadian Politics: Critical Approaches, $3^{\text {rd }}$ ed., Ontario: Nelson Thomson Learning, 2000.

Dye, Thomas, Understanding Public Policy, Michigan: Prentice-Hall, 1987.

Dye, Thomas; Zeigler, Harmon, "The Irony of Democracy," in Eva Etzioni-Halevy, (ed.), Classes and Elites in Democracy and Democratization: A Collection of Readings, New York: Garland Publishing, Inc., 1997

Dyment, David, The Reluctant Traveller: Understanding the International Activities of a Non-protodiplomatic Component Government: The Case of the Ontario Government from 1945 to 1995, Ph.D Thesis, Université de Montréal, April 1996.

Dyment, David, "The Ontario Government as an International Actor," Regional \& Federal Studies, vol. 11, no. 1, London: Frank Cass, Spring 2001.

Eayrs, James, The Art of the Possible: Government and Foreign Policy in Canada, USA: University of Toronto Press, 1961.

Economic and Social Research Council of the United Kingdom, Project on Federalism and Foreign Policy (INVESTIGATE)

Elazar, Daniel J., Federalism and the Way to Peace, Kingston: Institute of Intergovernmental Relations, 1994.

Elazar, Daniel J., (ed.), Federal Systems of the World: A Handbook of Federal, Confederal and Autonomy Arrangements, Jerusalem Institute for Federal Studies, United Kingdom, Longman Group, 1991.

Elkins, David J.; Simeon, Richard, (eds.), Small Worlds: Provinces and Parties in Canadian Political Life, Taylor \& Francis, 1980.

Fafard, Patrick; Harrison, Kathryn, Managing the Environmental Union: Intergovernmental Relations and Environmental Policy in Canada, School of Policy Studies, Queen's University: Kingston, 2000. 
Fanjoy, Emery M., "A View From the Inside: The Conference of New England Governors and Eastern Canadian Premiers," Canadian Parliamentary Review, Autumn 1990.

Farazmand, Ali, (ed.), "Emergent Theories of Organization: An Overview and Analysis," Emergent Organizations, $2^{\text {nd }}$ edition, USA, Greenwood Publishing Group, 2002.

Fearon, James D., "Domestic Politics, Foreign Policy, And Theories of International Relations," Annual Review of Political Science, 1998.

Feldman, Elliot J.; Feldman, Lily Gardner, "Canada," in Hans J. Michelmann, Panayotis Soldatos' (eds.), Federalism and International Relations: The Role of Sub-national Units, Oxford: Clarendon Press, 1990.

Feldman, Elliot J.; Feldman, Lily Gardner, "The Impact of Federalism on the Organization of Canadian Foreign Policy," Publius: The Journal of Federalism, 14/4, Fall 1984.

Fitzpatrick, P.J., "New Brunswick: The Politics of Pragmatism," in Martin Robin, (ed.), Canadian Provincial Politics: The Party Systems of the Ten Provinces, Prentice-Hall: Scarborough, 1972.

Fox, Paul A.; White, Graham, Politics in Canada, $\left(7^{\text {th }}\right.$ edition), Toronto: McGraw-Hill Ryerson Limited, 1984.

Friedman, Thomas, The Lexus and the Olive Tree, USA: Anchor Books, 2000.

Friesen, Jeffrey L., "The Distribution of Treaty-Implementing Powers in Constitutional Federations: Thoughts on the American and Canadian Models," Columbia Law Review, Vol. 94, No. 4, May 1994.

Fry, Earl H., The Expanding Role of State and Local Governments in U.S. Foreign Affairs, USA: Council on Foreign Relations, 1998.

Fry, Earl H., "The International Relations of Sub-National Governments: Coping with the 'Many Voices' Phenomenon in an Interdependent World," a paper presented at a round 
table on Pluralism and International Relations, International Political Science Association Conference, September 15-21, 1980.

Gagnon, Alain, "The Moral Foundation of Asymmetrical Federalism: A Normative Exploration of the Case of Québec and Canada," in Alain Gagnon, James Tully, (eds.), Multinational Democracies, U.K.: Cambridge University Press, 2001.

Gibbons, Roger, "Alberta's Intergovernmental Relations Experience," in Harvey Lazar, (ed.), Non-Constitutional Renewal: Canada: The State of the Federation 1997, Kingston: Institute of Intergovernmental Relations, 1998

González, Servando, The Nuclear Deception: Nikita Khrushchev and the Cuban Missile Crisis, InteliNet/InteliBooks, 2002.

Gourevitch, Peter, "The Second Image Reversed: The International Sources of Domestic Politics," International Organization, vol. 32, No. 4, Autumn 1978.

Government of Canada, News Release, "Signing of An Ottawa-Fredericton Memorandum of Understanding on New Brunswick's Participation in International Francophonie," March 18, 2009.

Granatstein, J.L.; Bothwell, Robert, Pirouette: Pierre Trudeau and Canadian Foreign Policy, University of Toronto Press, Toronto: 1991.

Gress, Franz, "Interstate Cooperation and Territorial Representation in Intermestic Politics," Publius: The Journal of Federalism, 26:1, Winter, 1996.

Griffith, Naomi, The Acadians: Creation of a People, Toronto: McGraw-Hill Ryerson, 1973.

Groen, James, "Intergovernmental Relations and the International Activities of Ontario and Alberta," Ph.D dissertation, Political Science, Queen's University, 1995.

Hale, Geoffrey; Kukucha, Christopher, "Investment, Trade, and Growth: Multilevel Regulatory Regimes in Canada," in Bruce Doern, Robert Johnson, (eds.), Rules, Rules, 
Rules, Rules: Multilevel Regulatory Governance, Toronto, University of Toronto Press, 2006.

Harmon, Michael M.; Mayer, Richard T., Organization Theory for Public Administration, USA: Little, Brown Publishing, 1986: 242-243 cited in Farazmand, 2002.

Hastie, Reid; Dawes, Robyn M., Rational Choice in an Uncertain Age: The Psychology of Judgment and Decision Making, Sage, 2001.

Hawkins, Freda, Canada and Immigration: Public Policy and Public Concern, Montreal: McGill Queen's Press, 1998

Heinbecker, Paul, Notes for a Presentation at the Conference, "Polycentric Governance? Sub-national Governments and Foreign Policy in an Age of Globalization," Norman Paterson School of International Affairs," Ottawa, June 7, 2006.

Hilliker, John; Barry, Donald, Canada's Department of External Affairs, Volume II, Coming of Age, 1946-1968, Montreal, McGill-Queen's University Press, 1995.

Hirst, Paul Q., (ed.), The Pluralist Theory of the State, New York: Routledge, 1989.

Hocking, Brian, Localizing Foreign Policy, Non-Central Governments and Multilayered Diplomacy, New York: St. Martin's Press, 1993.

Hocking, Brian, "Patrolling the 'Frontier: Globalization, Localization and the 'Actorness' of Non-Central Governments," in Aldecoa, Keating, (eds.), Paradiplomacy in Action, 1999.

Hocking, Brian, "Regional Governments and International Affairs: Foreign Policy Problem or Deviant Problem?," International Journal, Summer 1986.

Hocking, Brian, (ed.), Foreign Relations and Federal States, London: Leicester University Press, 1993. 
Hocking, Brian; Smith, Michael, World Politics, $2^{\text {nd }}$ Edition, Toronto, Prentice Hall, 1995

Hogg, Peter, Constitutional Law of Canada, $\left(4^{\text {th }}\right.$ edition), Toronto: Carswell, 1996.

Hogwood, B.W.; Gunn, L.A., Policy Analysis for the Real World, Oxford: Oxford University Press, 1984.

Hopkins, Raymond F., "The International Role of 'Domestic' Bureaucracy," International Organization, vol. 30, No. 3, Summer 1976.

House of Commons Debates, September 21, 1998, p. 8176, cited in Donald M. McRae, The Canadian Yearbook of International Law, Canada: UBC Press, 1998.

Howlett, Michael; Ramesh, M.; Perl, Anthony, Studying Public Policy, $3^{\text {rd }}$ ed., Toronto: Oxford University Press, 2009.

Hudson, Valerie M.; Vore, Christopher, "Foreign Policy Analysis Yesterday, Today, and Tomorrow," Mershon International Studies Review 39, 1995.

Hueglin, Thomas, "Federalism at the Crossroads: Old Meanings, New Significance," Canadian Journal of Political Science, 36:2, June 2003.

Hueglin, Thomas, "From Constitutional to Treaty Federalism: A Comparative Analysis," Publius: The Journal of Federalism, Fall, 2000.

Ibbitson, John, "The Premiers Sing in Harmony to Serenade Ottawa," The Globe and Mail, August 12, 2005

IGA, Corporate Strategy, URL: http://www.gnb.ca/0056/Publications/strategy-e.asp, Accessed: November 2008.

IGA, News Release, "Innovative Approach to Rural Community Development," April 26, 2005. 
Investment Review Branch, Industry Canada, Report Date: February 7, 2008.

Jackson, Robert J.; Jackson, Doreen, Politics in Canada: Culture, Institutions, Behaviour and Public Policy, $\left(6^{\text {th }}\right.$ edition), Toronto: Prentice Hall, 2006.

Jacomy-Millette, Annemarie., "Foreign Relations of Canadian Provinces," Library of Parliament Research Branch, Canada, 1984.

Jacomy-Millette, Annemarie, "Les activités internationals des provinces canadiennes," in Paul Painchaud, (ed.), De Mackenzie King à Pierre Trudeau : quarante ans de diplomatie canadienne, 1945-1985, Québec, Presses Université Laval, 1989.

James, Patrick, "Energy Politics in Canada, 1980-1981: Threat Power in a Sequential Game," Canadian Journal of Political Science, Vol. 26, No. 1, March 1993.

James, Patrick; Michelin, Robert, "The Canadian National Energy Program and Its Aftermath: Perspectives on an Era of Confrontation," American Review of Canadian Studies, Vol. 19, 1989.

James, Patrick; Michaud, Nelson; O'Reilly, Marc, (eds.), Handbook of Canadian Foreign Policy, Toronto: Lexington Books, 2006.

Jaques, Tim, "Buyer Being Sought: Atlantic Yam Closes," The Telegraph-Journal, January $21,2009$.

Jenkins, Rob, "India's States and the Making of Foreign Economic Policy: The Limits of the Constituent Diplomacy Paradigm," Publius, Vol. 33, No. 4, Emerging Federal Process in India, Autumn 2003

Jenson, Lloyd, Explaining Foreign Policy, New Jersey: Prentice-Hill, 1982. (68)

Johannson, P.R., "Provincial International Activities," International Journal, Spring 1978.

Johns, Carolyn, "Pressures on Canada's 'Environmental' Federation From Inside and Out," Federations, volume 1, number 4, May 2001. 
Johnston, Larry, Politics: An Introduction to the Modern Democratic State, Ontario: Broadview Press, 1997.

Joint Meeting of Energy and Environment Ministers (JMEEM), "Provincial and Territorial Statement on Climate Change Policy," (press release) Halifax, October 28, 2002.

Juillet, Luc, "The Public Service in an Age of Permeable Boundaries: Meeting the Challenge of Distinctiveness and Openness, Reflections on the APEX Summit 2000," Optimum, The Journal of Public Sector Management, Vol. 30, Nos. 3 / 4, April 2001.

Kaiser, Robert, "The Internationalization of Sub-national Politics: How Regional Integration Affects Federal Systems- The Case of Germany and the U.S.," Paper presented to the "International Institutions, Global Processes- Domestic Consequences" Conference, Duke University, Durham, North Carolina, April 1999.

Keating, Tom; Munton, Don, (eds.), The Provinces and Canadian Foreign Policy, Proceedings of a Conference, University of Alberta, Edmonton, Alberta, 28-30, March 1985, Toronto: Canadian Institute of International Affairs, 1985.

Kelly, Rita Mae; Palumbo, Dennis, "Theories of Policy-Making," in M.E. Hawkesworth, Maurice Kogan, (eds.), Encyclopedia of Government and Politics, New York: Routledge, 1992.

Keohane, Robert O.; Nye, Joseph S., Power and Interdependence, $\left(2^{\text {nd }}\right.$ edition), USA: Harper Collins, 1989.

Keohane, Robert O.; Nye, Joseph S., "Transgovernmental Relations and International Organizations," World Politics, 27, 1974.

Keohane, Robert O.; Nye, Joseph S., Institutions and State Powers, Boulder: Westview Press, 1989.

Kernaghan, Kenneth; Siegel, David, Public Administration in Canada, $\left(2^{\text {nd }}\right.$ edition), Scarborough: Nelson Canada, 1991. 
Kettner, Bonnie Raines, "Canadian Federalism and the International Activities of Three Provinces: Alberta, Ontario, and Quebec," M.A. Thesis, Simon Fraser University, 1980.

Kincaid, John, "Roles of Constituent Governments," Paper for the Forum of Federations seminar on "Foreign Relations of Constituent Units," Winnipeg, Canada, 11-12 May 2001.

Kincaid, John, "Constituent Diplomacy in Federal Politics and the Nation-State: Conflict and Cooperating," Federalism and International Relations: The Role of Subnational Units, USA, Oxford University Press, 1990.

Kingdon, John W., Agendas, Alternatives, and Public Policies, Boston: Little Brown, 1984.

Koerner, Wolfgang, "The Foundations of Canadian Federalism," Library of Parliament, Parliamentary Research Branch, December 1988.

Kornberg, Clarke, (eds.), Political Support in Canada, 1983, Chapter 4; Nossal, The Politics of Canadian Foreign Policy, 1989.

Kukucha, Christopher, "Domestic Politics and Canadian Foreign Trade Policy: Intrusive Interdependence, The WTO and the NAFTA," Canadian Foreign Policy, Vol. 10, No. 2, Winter 2003.

Kukucha, Chris, "Executive Federalism and the Federal-Provincial Committee System on International Trade: A Tool for the Administration of Foreign Policy?," University of Lethbridge, Alberta, working draft of paper for publication purposes, 2003.

Kukucha, Chris, "Theory, What Theory? The Theoretical Limitations of the Canadian Foreign Trade Literature," A Paper Prepared for "A Conference on a Review of Canada's International Policies," The Norman Paterson School of International Affairs, Carleton University, Ottawa, November 6-7, 2003.

Kukucha, Christopher John; Bratt, Duane, (eds.), Readings in Canadian Foreign Policy: Classic Debates and New Ideas, Toronto: Oxford University Press, 2006. 
Laghi, Brian, "East Coast Premiers Lobby for New Deal on Daycare Dollars," Globe and Mail, October 5, 2005.

LaSelva, Samuel V., The Moral Foundations of Canadian Federalism: Paradoxes, Achievements, and Tragedies of Nationhood, Montreal, McGill-Queen's Press, 1996

Latouche, Daniel, "Problems of Constitutional Design in Canada: Quebec and the Issue of Bicommunalism," Publius: Bicommunal Societies and Polities, Vol. 18, No. 2, Spring 1988.

Lazar, Harvey, "Managing Interdependencies in the Canadian Federation: Lessons from the Social Union Framework Agreement," Constructive and Cooperative Federalism, Kingston/Montreal: IIGR/IRPP: 2003

Lazar, Harvey, (ed.), Non-Constitutional Renewal: Canada: The State of the Federation 1997, Kingston: Institute of Intergovernmental Relations, 1998.

Lazar, Harvey; Telford, Hamish; Watts, Ronald L., (eds.), The Impact of Global and Regional Integration on Federal Systems: A Comparative Analysis, Montreal: McGillQueen's University Press, 2003.

Leach, Richard H., "Canadian Federalism Revisited," Publius: Crisis and Continuity in Canadian Federalism, Vol. 14, No. 1, Winter 1984

Leach, R., "Central Versus Provincial Authority in Making Foreign Policy for Canada," paper presented to the Seminar on Canadian-United States Relations of the University Consortium for Research on North America (UCRNA), Harvard University, 1981.

Lecours, André, "When Regions Go Abroad: Globalization, Nationalism and Federalism," Globalization, Multilevel Governance and Democracy: Continental, Comparative and Global Perspectives, (Conference paper), Kingston: Queen's University, May 2002.

Lecours, André, "Belgium," in Ann Lynn Griffiths, Karl Nerenburg, (eds.), Handbook on Federal Countries, 2005, Québec: McGill-Queen's Press, 2005. 
Lederman, W.R., "Unity and Diversity in Canadian Federalism: Ideas and Methods of Moderation," Canadian Bar Review, (53 $3^{\text {rd }}$ edition), 1975.

Leeson, Howard; Vanderelst, Wilfried, External Affairs and Canadian Federalism: The History of Dilemma, Toronto: Holt, Rinehart, Winston, 1973.

Leslie, Peter, "Regionalization, Multi-Level Governance, and Globalization," Globalization, Multilevel Governance and Democracy: Continental, Comparative and Global Perspectives, (Conference paper), Kingston: Queen's University, May 2002.

Leslie, Peter; Watts, R.L., (eds.), Canada: The State of the Federation, 1987-99, Kingston: Institute of Intergovernmental Relations, Queen's University, 1988.

Levy, T.A.; Munton, Don, "Federal-Provincial Dimensions of State-Provincial Relations," International Perspectives, March/April, 1976.

Levy, Thomas A., "Some Aspects of the Role of the Canadian Provinces in External Affairs: A Study in Canadian Federalism," Duke University, 1974.

Levy, Thomas A., "Provincial International Status Revisited," Dalhousie Law Review, 3, May 1976.

Lindblom, Charles E., "Still Muddling, Not Yet Through," Public Administration Review, Vol. 39, No. 6, November- December 1979; "The Science of Muddling Through," Vol. 19, Ibid, 1959.

Livingstone, William S., "A Note on the Nature of Federalism," Political Science Quarterly, Vol. 67, No. 1, 1952.

Lord, Bernard, Speech Delivered by the Honourable Bernard Lord, Premier of New Brunswick, Borderlines Conference, Calgary, Alberta, September 13, 2002.

Lord, Bernard, State of the Province Address 2001, Fredericton, New Brunswick, February 28, 2001 
Lower, A.R.M.; F.R. Scott, et al, Evolving Canadian Federalism, London: Cambridge University Press, 1958.

MacDonald Commission, "Intrastate Federalism in Canada," research paper, Toronto: University of Toronto Press, 1985, in van Loon and Whittington, 1987.

Mace, Gordon Mace; Bélanger, Louis; Bernier, Ivan, "Canadian Foreign Policy and Québec," in Maxwell A. Cameron, Maureen Appel Molot, (eds.), Democracy and Foreign Policy: Canada Among Nations 1995, Ottawa, Carleton University Press, 1995.

Mandel, Robert, "The Desirability of Irrationality in Foreign Policy Making: A Preliminary Theoretical Analysis," Political Psychology, Vol. 5, No. 4, December 1984.

Martin, Paul, "Address by Prime Minister Paul Martin on the Occasion of a Luncheon Hosted by Le Conseil des Relations Internationals de Montréal (CORIM), Centre d'études et de recherches de l'Univesité de Montréal (CERIUM) and the Montreal International Organization," Office of the Prime Minister, Montreal, Quebec, May 10, 2004.

Mazmanian, D.A., Sabatier, P.A., (eds.), "The Implementation of Public Policy: A Framework of Analysis," Effective Policy Implementation, Massachusetts: Lexington Books, 1981.

McCool, D.C., (ed.), Public Policy Theories, Models and Concepts: An Anthology, New Jersey: Prentice-Hall, 1995.

McIntosh, Tom, "Intergovernmental Relations, Social Policy and Federal Transfers After Romanow," Canadian Public Administration, vol. 47, no. 1, Spring 2004.

McNiven, James D.; Cann, Dianna, "Canadian Provincial Trade Offices in the United States," in Fry, Brown (eds.), The Expanding Role of State and Local Governments in U.S. Foreign Affairs, 1993.

McRoberts, Kenneth, "Unilateralism, Bilateralism and Multilateralism," in Richard Simeon (ed.), Intergovernmental Affairs, Toronto: University of Toronto Press, 1985. 
Meekison, J. Peter, (ed.), Canadian Federalism: Myth or Reality?, Toronto: Methuen Publications, 1968.

Meekison, J. Peter, Intergovernmental Relations in Federal Countries: A Series of Essays on the Practice of Federal Governance, Forum of Federations, Ottawa, 2002.

Memorandum of Understanding on Interprovincial Co-operation Between the Government of Manitoba and the Government of New Brunswick, Winnipeg, January 23, 2002.

Mercer, John, "Canadian Cities and Their Immigrants: New Realities," Annals of the American Academy of Political and Social Science, Vol. 538, Being and Becoming Canada, Sage Publishing, March 1995.

Merriam Webster's Collegiate Dictionary $\left(10^{\text {th }}\right.$ edition $)$, Massachusetts: MerriamWebster, Incorporated, 1995

Michaud, Nelson, "Bureaucratic Politics and the Shaping of Policies: Can We Measure Pulling and Hauling Games?," Canadian Journal of Political Science, Vol. 35, Issue 2, June 2002.

Michelmann, Hans J., "Federalism and International Relations in Canada and the Federal Republic of Germany," International Journal, 1986.

Michelmann, Hans J.; Soldatos, Panayotis, (eds.), Federalism and International Relations: The Role of Sub-national Units, Oxford: Clarendon Press, 1990.

Ministerial Charte de la Francophonie adoptée par la Conférence ministérielle de la Francophonie, Antananarivo, le 23 novembre 2005.

Monahan, Patrick J., "At Doctrine's Twilight: The Structure of Canadian Federalism," University of Toronto Law Journal, vol. 34, no. 1, Winter 1984.

Moody, Barry, "Acadia and Old Nova Scotia to 1784," in Martin Brook Taylor, Doug Owram, (eds.), Canadian History: Beginnings to Confederation, $2^{\text {nd }}$ ed., Toronto: University of Toronto Press, 1994. 
Morgenthau, Hans, Politics Among Nations: The Struggle for Power and Peace, New York: Knopf, 1948

Morse, E., "The Transformation of Foreign Policies: Modernization, Interdependence and Externalization," World Politics, 22, April 1970.

Mosca, Gaetano, The Ruling Class, New York: McGraw-Hill, 1939.

Moustakas, Clark E., Heuristic Research: Design, Methodology, and Applications, $2^{\text {nd }}$ Ed., USA: Sage, 1990.

Mueller, Dennis C., (ed.), Perspectives on Public Choice: A Handbook, Cambridge: Cambridge University Press, 1997.

Mueller, Dennis C., Public Choice III, Cambridge: Cambridge University Press, 2003.

Munton, Don; Kirton, John, "Beyond and Beneath the Nation-State: Province-State Interactions and NAFTA," paper presented to the annual meeting of the International Studies Association, San Diego, April, 1996.

Murray, Heather L., "The Asymmetrical Alternative: Is Asymmetrical Federalism A Viable Option For The Future?"' M.A. Thesis, Carleton University, 1998.

NEG/ECP Background, URL: http://www.cap-cpma.ca; Accessed: January 2009.

Neill, Robin, "Historical Atlantica: How the Impact of the Past will Shape Our Future," AIMS, Halifax, September 2007

Neufeld, Mark, "Democratization in/of Canadian Foreign Policy: Critical Reflections," Studies in Political Economy, No. 58, Spring 1999.

New Brunswick Telegraph-Journal, "Attracting newcomers no easy task," December 8, 2004. 
New Brunswick Telegraph Journal, Editorial, December 8, 2004.

New Brunswick Telegraph Journal, "Province Trying to Attract Chinese Students, Professors," May 20, 2006.

Notes for An Address by the Honourable Jim Peterson, Minister of International Trade, to the Canadian Association of Importers and Exporters, $74^{\text {th }}$ Annual Conference, Trade Show and Gala, Toronto, October 24, 2005.

New Brunswick Department of Agriculture and Aquaculture, Annual Report 2007-2008, 2008.

New Brunswick Department of Tourism and Parks, Province of New Brunswick, 20062007 Annual Report, November 2007.

New Brunswick Department of Fisheries, Province of New Brunswick, 2006-2007 Annual Report, November 2007.

New Brunswick Forest Products Association, "New Brunswick Forestry at a Glance," Hugh John Fleming Forestry Centre, Fredericton, New Brunswick, 2008.

Nossal, Kim Richard, The Politics of Canadian Foreign Policy, $\left(2^{\text {nd }}\right.$ edition), Canada: Prentice-Hall Canada Inc., 1989.

Nossal, Kim Richard, "The Democratization of Canadian Foreign Policy?," Canadian Foreign Policy, 1(3), 1993.

Nossal, Kim Richard, "The Impact of Provincial Governments on Canadian Foreign Policy," in Brown, Douglas M.; Earl H. Fry, (eds.), States and Provinces in the International Economy, California: Institute of Governmental Studies, 1993.

Neustadt, Richard, Alliance Politics, New York: Columbia University Press, 1970. 
O'Brien, Robert, "The Nuances of Multilevel and Global Governance," Globalization, Multilevel Governance and Democracy: Continental, Comparative and Global Perspectives, (Conference paper), Kingston: Queen's University, May 2002.

Office of Human Resources, "Grovernment of New Brunswick Workforce Profile," Province of New Brunswick, December 31, 2005.

Office of the Premier, Press Release, "Changes to Cabinet and Departments Aimed at Helping Province Achieve New Goals," February 14, 2006.

Office of the Secretary of State for External Affairs (OSSEA), Federalism and International Relations, Ottawa, 1968.

Ontario Ministry of Economic Development and Trade (MEDT), 2001-2 Business Plan.

OSSEA, Federalism and International Conferences on Education, Ottawa, 1968.

Ohmae, Kenichi, "Rise of the Nation State," Foreign Affairs, 72, Spring, 1993.

Olsen, Johan P., "Garbage Cans, New Institutionalism, and the Study of Politics," American Political Science Review, Vol. 95, No. 1, March 2001

Olstrom, Elinor, "A Behavioural Approach to the Rational Choice Theory of Collective Action," in Michael Dean McGinnis, (ed.), Polycentric Games and Institutions: Readings From the Workshop in Political Theory and Policy Analysis, USA, University of Michigan Press, 2000

Painchaud, Paul, "Fédéralism et théories de politique étrangère," Études internationales, vol. 5, no. 1, 1974.

Painter, Martin, Collaborative Federalism: Economic Reform in Australia in the 1990s, Melbourne: MacMillan.

Pal, Leslie, Beyond Public Policy Analysis: Public Issue Management in Turbulent Times, ( $2^{\text {nd }}$ edition), Canada: Nelson Thomson Learning, 2001 
Paolini, Albert J.; Jarvis, Anthony P.; Reus-Smit, Christian (eds.), Between Sovereignty and Global Governance: The United Nations, the State and Civil Society, New York: St. Martin's Press, Inc., 1998.

Paquet, Gilles, "The Many Are Smarter Than the Few," Optimum, The Journal of Public Service Management, Vol. 36, Issue 4, December 2006.

Paquin, Stéphane, "Paradiplomatie identitaire et diplomatie en Belgique fédérale: le cas de la Flandre," Canadian Journal of Political Science, Vol. 36, No. 3, July-August 2003.

Pelletier, Benoit, Open Letter Published in The Gazette, November 7, 2004.

Poitras, Jacques, The Right Fight: Bernard Lord and the Conservative Dilemma, New Brunswick, Goose Lane Editions, 2004

Pollard, Bruce G., "Canadian Energy Policy in 1985: Toward a Renewed Federalism?," Publius, Vol. 16, 1986.

Proceedings of the Focus India Plenary, Robertson Room, DFAIT Headquarters, Ottawa, June 19, 2007.

Province of Manitoba, Reaching Beyond Our Borders, Winnipeg, 2006.

Government of Manitoba, News Release, "New Brunswick and Manitoba Join Forces on Texas Mission," January 21, 2005.

Province of New Brunswick, BNB, Annual Reports 2001-2002 to 2006-2007.

Province of New Brunswick, Department of the Environment and Local Government, "Environmental Impact Assessment in New Brunswick," URL: http://www.gnb.ca/0009/0377/0002/0020-e.pdf; Accessed, January 2009.

Province of New Brunswick, IGA, Annual Reports 2001-2002 to 2006-2007. 
Province of New Brunswick, Economic Development, Tourism and Culture, News Release, "Textile Plant to Create 350 Jobs on Acadian Peninsula," February 23, 2000.

Province of New Brunswick, Executive Council Act, Assented April 11, 2003, New Brunswick Acts 2003.

Province of New Brunswick, Progress Report on Prospering in a Global Community: New Brunswick's International Strategy, January 2006.

Province of New Brunswick, Report of the New Brunswick Commission on Canadian Federalism, Fredericton, January 1992.

Province of New Brunswick, Greater Opportunity: New Brunswick's Prosperity Plan, 2002.

Province of New Brunswick, IGA, "Francophonie/ Official Languages," URL: http://www.gnb.ca/0056/Francophonie/index-e.asp, Accessed: January 12, 2009.

Province of New Brunswick, Memoranda to All Deputy Ministers, "International Corporate Travel," Office of the Deputy Minister, IGA, October 5, 2005 (obtained through written request to IGA).

Province of New Brunswick, Memoranda, "Postponement of International Business Symposium," Department of Intergovernmental Affairs, Province of New Brunswick, August 18, 2006 (obtained through written request to IGA).

Province of New Brunswick, News Release, "Mockler to Present New Brunswick's Priorities in Ottawa," January 2, 2004.

Province of New Brunswick, News Release, "New Brunswick International Day Takes Place in Ottawa," March 9, 2004.

Province of New Brunswick, News Release, "New Cooperation Agreement with Département de la Vienne, France," November 13, 2003. 
Province of New Brunswick, News Release, Office of the Premier/Business New Brunswick, "New Brunswick to Establish Population Growth Secretariat," February 16, 2007.

Province of New Brunswick, Prospering in a Global Community: New Brunswick's International Strategy, Fredericton, 2003.

Province of New Brunswick, Office of Human Resources, "Government of New Brunswick Workforce Profile," 2005.

Province of New Brunswick, IGA, Press Release, "International Francophonie Day, March 20 (04/03/19)," March 19, 2004.

Province of New Brunswick, Self Sufficiency Task Force, The New Brunswick Reality Report, Part I: At The Crossroads, Fredericton, January 2007a.

Province of Newfoundland and Labrador, Speech from the Throne, $2^{\text {nd }}$ Session of the $46^{\text {th }}$ General Assembly of the Province of Newfoundland and Labrador, March 25, 2009.

Province of Nova Scotia, Crown Corporation Business Plans for the Fiscal Year 20042005, Nova Scotia Business Incorporated, Business Plan 2004-2005.

Putnam, Robert, "Diplomacy and Domestic Politics: The Logic of Two-Level Games, International Organization, 42(3), 1988.

Québec Ministry of International Relations (MRI)- URL: http://www.mri.gouv.qc.ca/en/index.asp. Accessed: September 2008.

Queen's Printer, Canada, Federalism and International Relations, Ottawa, 1968.

Queen's Printer, Federalism and International Conferences on Education: A Supplement to Federalism and International Relations, 1968.

Patton, Michael Quinn, Qualitative Research and Evaluation Methods, $3^{\text {rd }}$ ed., California: Sage, 2002. 
Philips, Andrew, "Province Leading Eight-Day Mission to France," New Brunswick Telegraph Journal, November 1, 2003.

Rabin, Jack, Encyclopedia of Public Administration and Public Policy, Marcel Dekker, 2003.

Rawls, John; Political Liberalism, USA, Columbia University Press, 1993

Rifaat, Cherif, Immigrants Adapt, Countries Adopt... Or Not: Fitting into the Cultural Mosaic, Montreal: New Canadians Press, 2004.

Riker, W.H., Federalism: Origin; Operation; Significance, Boston: Little, Brown, 1964.

Rittberger, Volker, (ed.), Global Governance and the United Nations System, New York: United Nations University Press, 2001.

Roberge, Ian, "The Internationalization of Public Policy and the Prospects for a Theory of Multi-Level Governance," Federal Governance: A Graduate Journal of Theory and Politics, 1:2, 2003.

Robertson, Ian Ross, "The Maritime Colonies, 1784 to Confederation," in Taylor, Owran, (eds.), Canadian History, 1984.

Rocher, François; Smith, Miriam, (eds.), New Trends in Canadian Federalism, $2^{\text {nd }}$ edition, Peterborough: Broadview Press, 2003.

Rosenau, James N., Along the Domestic-Foreign Frontier: Exploring Governance in a Turbulent World, Cambridge: Cambridge University Press, 1997.

Rosenau, James N., "A Pre-Theory Revisited: World Politics in an Era of Cascading Interdependence," International Studies Quarterly, 28, 1984.

Rosenau, James N., "Foreign Policy as an Issue-Area," in Rosenau (ed.) Domestic Sources of Foreign Policy, New York: The Free Press, 1967. 
Roy, Mathieu, Treaty-Making Powers of Canadian Provinces: Revisiting the 1960s Debate in Light of Subsidiarity and Federal Loyalty, Master's Thesis, Graduate Department of Law, University of Toronto, 2005.

Russell, Peter, "The Supreme Court and Federal Provincial Relations: The Political Use of Legal Resources, Canadian Public Policy, 11, 2, 1985.

Sada Solana, Carlos M.; Hale, Geoffrey E., "A Tale of Two Systems- Contrasting Federal and Cross-Border Relations Governments in Mexico and Canada," (draft paper), May 56, 2003.

Saint John Telegraph Journal, "N.S.'s Immigration Strategy Ambitious," December 7, 2004.

Salmon, Trevor C.; Michael Keating, (eds.), The Dynamics of Decentralization: Canadian Federalism and British Devolution, Montreal \& Kingston: McGill-Queen's University Press, 2001.

Saskatchewan Institute of Public Policy (SIPP), conference advertisement for "Constructing Tomorrow's Federalism: New Routes to Effective Governance," Saskatchewan, March 24-26, 2004.

Sauvé, Pierre, "Trade, Education and the GATS: What's In, What's Out, What's All the Fuss About?," Higher Education Management and Policy, vol. 14, no. 3, November 2002 (final draft).

Savioe, Donald J., Federal-Provincial Collaboration: The Canada-New Brunswick General Development Agreement, McGill-Queen's University Press: Toronto, 1981.

Savoie, Donald, Governing From the Centre: The Concentration of Power in Canadian Politics, Toronto: University of Toronto Press, 1999.

Pulling Against Gravity: Economic Development in New Brunswick During the McKenna Years, Institute for Research on Public Policy, Winter, 2001. 
_ "Searching for Accountability in a Government Without Boundaries," Canadian Public Administration, vol. 47, no. 1, Spring 2004.

Schlegel, J.P., "Federalism and Canadian Foreign Policy," The Round Table, no. 282, April 1981. (187)

Schmitz, Gerald J., "Foreign Policy White Papers and the Role of Canada's Parliament: Paradoxical But Not Without Potential," Paper presented at Annual Meeting of CPSA, University of Western Ontario, London, June 3, 2005.

Simeon, Richard, "Important? Yes. Transformative? No. North American Integration and Canadian Federalism," in Lazar et al, (eds.), Montreal, McGill-Queen's University Press, 2003.

, "Recent Trends in Federalism and Intergovernmental Relations in Canada: Lessons for the UK?," in Salmon, Trevor C.; Michael Keating, (eds.), The Dynamics of Decentralization: Canadian Federalism and British Devolution, Montreal \& Kingston: McGill-Queen's University Press, 2001.

Simeon, Richard; Cameron, David, "Intergovernmental Relations and Democracy: An Oxymoron If There Ever Was One," in Canadian Federalism: Performance, Effectiveness, and Legitimacy, Herman Bakvis; Grace Skogstad, (eds.), Don Mills: Oxford University Press, 2002.

Simeon, Richard; Robinson, Ian, State, Society and the Development of Canadian Federalism, Research Studies of the Royal Commission on the Economic Union and Development Prospects for Canada, vol. 70, Toronto, University of Toronto Press, 1990.

Smiley, Donald V., "An Outsider's Observations of Federal-Provincial Relations Among Consenting Adults," in

Simeon, Richard, (ed.), Confrontation and Collaboration: Intergovernmental Relations In Canada Today, Toronto: Institute for Public Administration in Canada, 1979.

Simeon, Richard, Canada in Question: Federalism in the Eighties, 3rd ed., Toronto: McGraw-Hill Ryerson, 1980. 
Simeon, Richard, "Federal-Provincial Conflict in Canada," Publius: The Journal of Federalism, vol. 4, no. 3, Summer 1974.

Simeon, Richard, The Federal Condition in Canada, Toronto: McGraw-Hill Ryerson, 1987.

Simeon, Richard, "Territorialism and Canadian Political Institutions," Canadian Public Policy, (3) 1977.

Simeon, Richard, "The Rowell-Sirois Report, Provincial Autonomy, and Post-War Canadian Federalism," Canadian Journal of Economics and Political Science, 28, February, 1962.

Simeon, Richard, The Structural Problem of Canadian Federalism," Canadian Public Administration, vol. 14, no. 4, Fall 1971.

Simeon, Richard; Nugent, Amy, "Parliamentary Canada and Intergovernmental Canada: Exploring the Tensions," in Herman Bakvis, Grace Skogstad, (eds.), Canadian Federalism: Performance, Effectiveness, and Legitimacy, $2^{\text {nd }}$ ed., Toronto: Oxford University Press, 2008.

Simon, Herbert A., "Rationality in Political Behaviour," Political Psychology, Vol. 16, No. 1,1995

Skogstad, Grace, "Intergovernmental Relations and the Politics of Environmental Protection in Canada," in Kenneth M. Holland, Frederick Lee Morton, Brian Galligan, (eds.), Federalism and the Environment: Environmental Policymaking in Australia, Canada, and the United States, Greenwood Publishing, 1996.

Skogstad, Grace, "International Trade Policy and Canadian Federalism: A Constructive Tension?," Canadian Federalism: Performance, Effectiveness, and Legitimacy, 2002.

Smiley, Donald V.; Watts, Ronald L., Intrastate Federalism in Canada, Research Studies of the Royal Commission on the Economic Union and Development Prospects for Canada, vol. 39, Toronto: University of Toronto Press, 1985. 
Smith, Heather, "Canadian Federalism and International Environmental Policy Making: The Case of Climate Change," Working Paper No. 5, Kingston: Institute of Intergovernmental Relations, Queen's University, 1998.

Smith, Jennifer, "The Meaning of Provincial Equality in Canadian Federalism," Working Paper 1998(1), Kingston: Institute of Intergovernmental Relations, Queen's University, 1998.

Smith, Steve; Clarke, Michael, (eds.), Foreign Policy Implementation, London: George Allen and Unwin, 1985. (7)

Soldatos, Panayotis, "Cascading Sub-national Paradiplomacy in an Interdependent and Transnational World," in Douglas M. Brown and Earl H. Fry, (eds.), States and Provinces in the International Economy, Kingston: Institute of Intergovernmental Relations, Queen's University, 1993.

, "An Explanatory Framework for the Study of Federated States as Foreign Policy Actors," in Michelmann, Soldatos, (eds.), 1990.

Solomon, Lawrence, "Best Immigration Policy is the Freest," The National Post, November 29, 2005.

Soward, F.H., "External Affairs and Canadian Federalism," in Lower, A.R.M; and Scott, F.R., Evolving Canadian Federalism, London: Cambridge University Press, 1958

Spiro, Peter J., "The Limits of Federalism in Foreign Policymaking," Intergovernmental Perspective, 16, Spring 1990.

Stairs, Denis, "The Conduct of Canadian Foreign Policy and the Interests of Newfoundland and Labrador," Royal Commission on Renewing and Strengthening Our Place in Canada, March 2003.

Stairs, Denis, "Public Opinion and External Affairs: Reflections on the Domestication of Canadian Foreign Policy," International Journal 33, Winter 1978. 
"State and Local Governments in International Affairs: ACIR Findings and Recommendations," Intergovernmental Perspective, 20, Fall 1993/Winter 1994.

Statistics Canada, Censuses of Population, 1851-2001. URL: http://www40.statcan.ca/101/cst01/demo62e.htm. Accessed: February 24, 2007.

Statistics Canada, 2006 Census of Population, http://www40.statcan.gc.ca/101/cst01/ demoll lb-eng.htm. Accessed: May, 2008.

Statistics Canada, censuses of population, 1956 to 2006, http://www12.statcan.ca/english/census06/analysis/popdwell/ProvTerr1.cfm, Accessed: September, 2007.

Statistics Canada, http://www40.statcan.ca/101/cst01/demo02a.htm. Accessed: February 13, 2007.

Statistics Canada. URL: http://www40.statcan.ca/101/cst01/famil108a.htm. Accessed: February 13, 2007

Stevenson, Garth, Unfulfilled Union: Canadian Federalism and National Unity," Toronto: MacMillan Press, 1989.

Stevenson, Garth, "Political Constraints and the Province-Building Objective," Canadian Public Policy, February 1980,

Gendron, Robin Stewart; Dandurand, Raoul, Towards a Francophone Community: Canada's Relations with France and French Africa, 1945-1968, Montreal, McGillQueen's Press, 2006.

Story, Donald C., "Government- a practical thing:" Towards a Consensus on foreign policy administration, in R.B. Byers and Robert W.; (eds.), Canada Challenged: The Viability of Confederation, Toronto: CIA, 1979.

Swanson, R.F., "The Range of Direct Relations Between States and Provinces," International Perspectives, March/April 1976. 
Swimmer, Gene, How Ottawa Spends, 1997-98: Seeing Red, A Liberal Report Card, Montreal: McGill-Queen's Press, 1997.

Tarlton, Charles D., "Symmetry and Asymmetry as Elements of Federalism: A Theoretical Speculation," Journal of Politics, Vol. 27, 1965.

Telford, Hamish, "Expanding the Partnership: The Proposed Council of the Federation and the Challenge of Glocalization," Constructive and Cooperative Federalism? A Series of Commentaries on the Council of the Federation, IRPP, Montreal, 2003.

Thérien, Jean-Philippe, "Canada and Francophone Multilateral Cooperation," in John English, Norman Hillmer, (eds.), Making a Difference? Canada's Foreign Policy in a Changing World Order, Toronto, Lester Publishing Limited, 1992.

Thorburn, Hugh G., Politics in New Brunswick, Toronto: University of Toronto Press, 1961.

Tremblay, Reeta, "Review of Federalism and International Relations: The Role of Subnational Units," in Michelmann, Soldatos, (ed.), 1990.

Tucker, M., Canadian Foreign Policy: Contemporary Issues and Themes, Toronto: McGraw-Hill, 1980. (53-60)

Vanderelst, Wilfried, External Affairs and Canadian Federalism: The History of Dilemma, Toronto: Holt, Rinehart, Winston, 1973

Van Loon, Richard J.; Whittington, Michael S., The Canadian Political System: Environment, Structure and Process, (4 ${ }^{\text {th }}$ edition), Canada: McGraw-Hill Ryerson Ltd., 1987.

Vengroff, Richard; Rich, Jason, "Foreign Policy by Other Means: Paradiplomacy and the Canadian Provinces," in Patrick James, Nelson Michaud, Marc J. O'Reilly, (eds.), Handbook of Canadian Foreign Policy, Maryland, Lexington Books, 2006.

Viles, M.J.C., The Structure of Federalism, Oxford: Oxford University Press, 1961. 
Vipond, Robert C., "1787 and 1867: The Federal Principle and Canadian Confederation Reconsidered," Canadian Journal of Political Science, No. 1, March 1989

Vipond, Robert C., "Constitutional Politics and the Legacy of the Provincial Rights Movement in Canada," Canadian Journal of Political Science, June 1985.

Vipond, Robert C., Liberty and Community: Federalism and the Failure of the Canadian Constitution, Albany: State University of New York Press, 1991.

Wallerstein, Immanuel, World-Systems Analysis, ed. 4, USA: Duke University Press, 2004.

Walt, Stephen M., "International Relations: One World, Many Theories," Foreign Policy, Spring 1998.

Waltz, Kenneth, Man, the State and War: A Theoretical Analysis, New York: Columbia University Press, 1959.

Watts, Ronald L., Executive Federalism: A Comparative Analysis, Kingston: Institute of Intergovernmental Relations, Queen's University, 1989.

Watts, Ronald L., "Federalism, Federal Political Systems, and Federations," Annual Review of Political Science, 1:117:37, 1998.

Watts, Ronald L., Comparing Federal Systems in the $1990 \mathrm{~s}$, ( ${ }^{\text {nd }}$ edition), Kingston: Institute of Intergovernmental Relations, Queen's University, 1996.

Watts, Ronald L., The Federal Idea and its Contemporary Relevance, Kingston: Institute of Intergovernmental Relations (IIGR), 2007.

Weiler, Joseph, The Constitution of Europe: "Do the New Clothes Have an Emperor?" and Other Essays on European Integration, Cambridge University Press, 1999

Wheare, K.C., Federal Government, (4 ${ }^{\text {th }}$ edition), Oxford: Oxford University Press, 1963. 
White, Graham, "Big is Different From Little: On Taking Size Seriously in the Analysis of Canadian Governmental Institutions," Canadian Public Administration, 33(4), 1990.

Whyte, John, "Federal Powers Over the Economy: Finding New Jurisdictional Room," Canadian Business Law Journal, 13, 1987.

Winham, G.R., "Bureaucratic Politics and Canadian Negotiation," International Journal, 34, Winter 1978-7. (73)

Young, R.A.; Faucher, P.; Blais, A., "The Concept of Province-Building: A Critique," Canadian Journal of Political Science, December 1984.

\section{Interviews and Broadcasts}

Anonymous, BNB Official, Province of New Brunswick, Fredericton, February 17, 2004.

Anonymous, DFAIT Official, February 17, 2004.

Anonymous, Education Official, Province of New Brunswick, Fredericton, April 2004.

Anonymous, Interview, Fredericton, April 3, 2009.

Anonymous, Interview, Fredericton, March 31, 2009.

Anonymous, Interview, New Brunswick Deputy Minister, Fredericton, May 29, 2008.

Anonymous, Telephone Interview, Fredericton, April 14, 2009.

Canadian Broadcasting Corporation, television (CBC-TV), reporter Sonya Varma profiles a French couple who moved to Dieppe to open a bakery under the nominee program, Dieppe, New Brunswick, April 27, 2004. 
CTV National News, "Harper Announces UNESCO deal with Québec," May 5, 2006. URL: http://www.ctv.ca, Accessed: May 6, 2006.

Cyr, Mirelle, Assistant Deputy Minister, IGA/FOLB, Province of New Brunswick, Fredericton, January 14, 2009.

Kearney, Arnold, Director, FOLB, Province of New Brunswick, Fredericton, March 29, 2004.

Kershaw, John, Deputy Minister, IGA, Province of New Brunswick, Fredericton, January 15, 2004; May 3, 2007.

Lord, Bernard, Premier of New Brunswick, Fredericton, April 16, 2004, May 8, 2007.

Malone, Kevin, Secretary to Cabinet, ECO, Province of New Brunswick, Fredericton, January 26, 2004.

McKay, Jim, Deputy Minister, IGA, Province of New Brunswick, Fredericton, May 11, 2004.

McLaughlin, David, Deputy Minister, Commission on Legislative Democracy, April 2, 2004.

Roy, Maurice, Director- NBCC, Province of New Brunswick, Fredericton May 11, 2004.

Wood, Gary, A/Executive Director, IGA, Province of New Brunswick, Fredericton, April 2004. 